\title{
INFORMATION, DECISION AND PLANNING SUPPORT FOR INDUSTRIAL RISK MANAGEMENT IN INDIA
}




\section{Graduation committee:}

Chairman/Secretary:

prof.dr.ir. A. Veldkamp University of Twente

Promotor:

Prof.dr.ir. M.F.A.M. van Maarseveen University of Twente

Co-promotors:
Dr. C.J. van Westen
University of Twente

Dr. J. Flacke

University of Twente

Members:

Prof.dr. B.J.M. Ale

Delft University

Dr. M. D. Christou

Joint Research Centre, EC

Prof. S. Roy

IIT, Bombay, India

Prof.dr. M.J. Kraak

University of Twente

Prof.mr.dr.ir. J.A. Zevenbergen

University of Twente

ITC dissertation number 298

ITC, P.O. Box 6, 7500 AA Enschede, The Netherlands

ISBN: $\quad 978-90-365-4278-4$

DOI: $\quad 10.3990 / 9789036542784$

Printed by: ITC Printing Department

(C) Debanjan Bandyopadhyay, Enschede, The Netherlands

All rights reserved. No part of this publication may be reproduced without the prior written permission of the author.

\section{UNIVERSITY OF TWENTE.}

TC FACULTY OF GEO-INFORMATION SCIENCE AND EARTH OBSERVATION 


\title{
INFORMATION, DECISION AND PLANNING SUPPORT FOR INDUSTRIAL RISK MANAGEMENT IN INDIA
}

\author{
DISSERTATION
}

to obtain

the degree of doctor at the University of Twente, on the authority of the rector magnificus, prof.dr. T.T.M. Palstra, on account of the decision of the graduation committee, to be publicly defended

on Thursday 15 December 2016 at 16.45 hrs

by

Debanjan Bandyopadhyay

born on $3^{\text {rd }}$ July, 1972

in Chinsurah, India 
This thesis is approved by

Prof.dr.ir. M.F.A.M. van Maarseveen (promoter)

Dr. C.J. van Westen (co-promoter)

Dr. J. Flacke (co-promoter) 


\section{Summary}

Thirty years have elapsed since the Bhopal industrial disaster occurred in India, yet several weaknesses remain in the framework for governance of industrial risk. As a result, significant amplification of risk can be noted in more than hundred areas where clusters of hazardous industries are located. A key gap is concerned with the availability of valid and up-to-date information on hazards and vulnerability which in turn affects the ability to arrive at rational decisions on risk reduction and mitigation. The goal of this research is to design and develop an online platform that can support decision making on different aspects of industrial risk management, focusing on the specific situation in India. This research takes on from the objectives of the Environment Risk Reporting and Information System (ERRIS) project, which developed one of the first online spatial information system for industrial risk management in India.

A review of the policy, regulatory and institutional framework for industrial risk management in India is presented in the initial section to understand the country context and identify key gaps in the current system. The review revealed that there is still no clear policy on governance of industrial risk. However, certain inter-linkages exist between other related policy statements of the government like the disaster management policy, environmental policy and the draft land use utilisation policy. On the regulatory front, there are several Acts and Rules that focus on management of industrial hazards. Specific provisions of these regulations focus on identification of hazards and application of management tools like safety audits and risk assessment. However, the scientific basis for industrial hazard and risk related regulation is not well established. For example, there are no detailed guidelines for specific levels of risk which can provide a benchmark for risk evaluation by hazardous industries. In addition, specific responsibilities of competent authorities with regard to management of industrial risk are not well laid out in regulations. There is also a lack of adequate institutional capacity that affects effective implementation and monitoring of compliance to regulatory provisions.

As a part of the methodology for this research, several rounds of consultations have been undertaken with key risk actors to have a better understanding of the issues being faced in relation to risk management decision making. Interactions were held with policy and regulatory bodies like the relevant ministries, National Disaster Management Authority, State Pollution Control Boards, Factories Inspectorates to understand their views on industrial risk management and the decision making process for risk mitigation and control. In addition, a range of other risk actors including planning agencies, industry associations, land revenue department, 
association and groups were engaged. These interactions helped in understanding the needs and requirements of different risk actors from an information, decision and planning support platform that could provide necessary information and support decision making at different stages of risk management.

Based on this appreciation, a versatile framework for information systems, decision analysis and planning support tools has been conceptualised, applicable for risk governance of a typical industrial town in India. Four systems have been designed and developed as a part of this research. The Risk Management Information System (RMIS) was designed to be the base information management platform and provide analytical capabilities to decision makers and relevant information to risk actors through a web-GIS interface. Developed further based on the objectives of the ERRIS project, the RMIS design has been undertaken taking into consideration an interoperable and context-aware SDI framework, with information services which would be capable of integrating and sharing information from several sources. The system conceptualization accounts for consolidation of information on industrial hazard sources, elements at risk and vulnerabilities, other planning related information, and real time information from sensors.

The RMIS portal may be considered as an information-based DSS that supports focused queries on risk information, enables map visualization, and present qualitative information in the form of tables and charts to stakeholders based on their needs. The RMIS functionalities cover all the regulatory information dissemination or sharing requirements that hazardous industries are required to convey to regulators, or interested stakeholders who can be affected by industrial accidents. With further development, it has the potential to provide value-added information such as risk maps for industrial areas which can, for example, be used by insurance companies for deciding premiums or by people to make home buying decisions.

As a second application, the Emergency Decision Support System (EDSS) have been designed with the objective of providing a distributed tool for aiding decision making during industrial emergency planning and response exercises. Key aspects that have been taken into account in its conceptualisation are the difficulties in consolidating a wide array of information from different sources while planning for or responding to an industrial emergency, and the need for quick decision-making. Subsequently, through its visualization and information dissemination interface, it can convey the required information to stakeholders based on their need so that appropriate preventive and protective actions can be taken up to reduce damages and save injuries to vulnerable people. A key advantage of the EDSS is that it provides the scope for the decision makers to act on updated 
information, undertake dynamic modelling of potential consequences, and provide a live 'emergency plan' in line with regulatory requirements instead of the paper plans. Reviews have shown that the paper plans submitted to regulators are often outdated or lack vital information that may be required by emergency planners and responders at the time when an accident unfolds. The other advantage of adopting an IT based solution for emergency management is the ability to integrate information from online sensors to provide a real-time picture on dynamic aspects like prevailing wind direction, the position of emergency responders.

The third component of the system is the quantitative risk assessment tool called the QRA Risk Mapper. At present, there is no standardised and consistent methodology that can be used by regulators, industry or other stakeholders for estimating risks at an area level for a hazardous industry cluster. The QRA Risk Mapper provides the scope for adoption of a harmonised methodology for risk estimation that can be operated and shared through a distributed system and provide necessary support for management of risks through the regulatory and planning framework. The QRA Risk Mapper has been conceptualised and designed so that it synchronises hazard and vulnerability related information from the RMIS database and integrate them with risk calculation models and tools, to provide a cumulative risk map of an area. Based on visualization of risk levels at a resolution of a $100 \mathrm{~m}$ grid, spatial planning decisions on where to site a new hazardous industry, residential or commercial area can be made in an existing industrial area.

The fourth component of the system is a Spatial Multi-criteria Evaluation (SMCE) based Planning Support System (PSS) for Risk Guided Land Use Planning. India is witnessing fast-paced economic development and has a high density of population, and urban planners are bound to witness conflicting interests amongst stakeholders on the suitability of land for further development of industries and meeting the housing and recreational needs of people. The SMCE Planner provides a system for guiding land use planning at local level through the development of hazard and vulnerability based indicators and then applying multi-criteria analysis for evaluating the suitability of future land use development proposals. The PSS design allows for participation and deliberation to occur through the system interface and through discussions amongst stakeholders leading to alternative planning scenarios. It is expected that support systems like this will be used to guide the creation of land utilization zones (LUZs) and land use management areas (LMAs) according to the draft National Land Utilization Policy formulated by the government of India.

The success in implementation of these systems will depend on several factors. This includes establishment of mechanisms to ensure that key risk- 
related data are kept up-to-date, appropriate sharing of data occurs through Spatial Data Infrastructure platforms, agreement of risk assessment methodologies and models that form the core for the decision support tools, and finally the adequate training of the risk actors and other potential users so that the systems gain acceptability. It is expected that the systems would undergo further calibration and refinement, when it is further put through testing and evaluation exercises by users.

The evaluation of the information, decision and planning support tools by potential domain experts and user groups is a key factor that would influence the success of the tools, when deployed. Several methodologies have been formulated to evaluate or test whether a decision or planning support system is capable of providing appropriate guidance to a decision in an appropriate situational context. This research provided limited scope for evaluation of the decision and planning support systems that were designed and developed. Limited formal testing for the EDSS and the QRA Risk Mapper was undertaken as a part of national level workshop where users from different states participated and provided feedback through a customised questionnaire, after being trained in the use of the system.

This research has attempted to build a bridge between ICT applications and the domain of industrial risk management in India. It is expected that the conceptualization and design of the set of information, decision and planning support systems undertaken through this research would generate interest in further research in India on how industrial risk policies, regulations and methods can be formulated and applied in practice to make society in India safer. In addition, the exploration of possibilities for implementation of these systems at scale would result in research on how such systems can be further refined and adapted. 


\section{Samenvatting}

Hoewel er al dertig jaar is verstreken sinds de industriële giframp in Bhopal, India, kunnen er nog steeds verscheidene zwakke punten worden aangemerkt in het kader van industriële risicobeheersing. Mede daardoor is er sprake van een significante uitbreiding van risico's in meer dan honderd industriële steden waar complexen van gevaarlijke industrieën zijn gevestigd. Een belangrijke omissie is de beschikbaarheid van deugdelijke en actuele informatie over ongevallen en kwetsbaarheid, hetgeen zijn weerslag heeft op de mogelijkheid om te komen tot rationele beslissingen om risico's te verkleinen en te verzachten. Het doel van dit onderzoek is het ontwerp en de ontwikkeling van een online platform, dat besluitvormers kan ondersteunen ten aanzien van verschillende aspecten van industriële risicobeheersing, in het bijzonder gericht op de specifieke situatie in India. Dit onderzoek heeft als uitgangspunt genomen de doelstellingen van het Environment Risk Reporting and Information System (ERRIS) project dat is opgezet als een eerste online ruimtelijk informatiesysteem voor industriële risicobeheersing in India. Een uitgebreide literatuurstudie heeft plaatsgevonden naar de huidige wetenschappelijke inzichten met betrekking tot informatie-, besluitvormingsen planning support systemen.

Een kritische beschouwing is uitgevoerd met betrekking tot het beleid en het kader van regelingen en instituties betreffende industriële risicobeheersing in India om de context van het land te kunnen begrijpen en om belangrijke lacunes te kunnen signaleren in het huidige system, die kunnen worden opgeheven door de toepassing van informatietechnologie. De verkenning heeft aangetoond dat er nog altijd geen helder beleid is op het gebied van industriële risicobeheersing. Echter, er bestaan enkele dwarsverbanden met gerelateerde beleidsuitspraken van de overhead zoals het beleid op het gebied van rampenbeheersing, het milieubeleid en het concept ruimtelijke ordening-beleid. Op het gebied van regelgeving zijn er Wetten en Regelingen gericht op de beheersing van industriële risico's, maar het Indiase stelsel van regelgeving op het gebied van milieu en risicomanagement is uitermate dynamisch, en wijzigingen in de belangrijkste regelgeving komen veelvuldig voor door amendementen van bevoegde organisaties en agentschappen met een eigen regelgeving. Specifieke voorzieningen in regelgeving ten aanzien van industriële risico's richt zich op identificatie van risico's en de toepassing van management tools zoals veiligheid audits en risico-evaluatie. Echter de wetenschappelijke onderbouwing van deze zaken is niet erg goed ontwikkeld. Zo zijn er bijvoorbeeld geen heldere richtlijnen voor de te gebruiken methodiek van risico-evaluatie, of voor het hanteren van bepaalde risico niveaus, die als een benchmark kunnen fungeren bij een evaluatie van risico's bij gevaarlijke industriële activiteiten. Daarnaast zijn de verantwoordelijkheden van bevoegde autoriteiten met betrekking tot 
risicobeheersing onvoldoende vastgelegd in regelingen. En er is gebrek aan adequate institutionele capaciteit, die zorg draagt voor effectieve implementatie en het monitoren van de naleving van regels.

Als onderdeel van de onderzoeksmethodiek zijn meerdere bijeenkomsten georganiseerd met belangrijke actoren om een beter begrip te krijgen van de onderwerpen die spelen bij de besluitvorming rond risicobeheersing. Overleg is gevoerd met organisaties op het gebied van beleid en regelgeving zoals relevante ministeries, de National Disaster Management Authority, State Pollution Control Boards, en Factories Inspectorates om kennis te nemen van de verschillende gezichtspunten op het gebied van industriële risicobeheersing, en het besluitvormingsproces rond risico reductie en management. Daarnaast zijn nog een hele reeks andere belanghebbenden geconsulteerd waaronder planningsorganisaties, industriële samenwerkingsorganisaties, het Land Revenue Department, en andere organisaties en groeperingen. Dit heeft geleid tot een nog beter begrip van behoeften en eisen van belanghebbenden ten aanzien van een ondersteunend platform voor informatieverzameling, besluitvorming en planning in de verschillende stadia van risicobeheersing.

Gebaseerd op deze waardevolle informatie is een veelzijdig raamwerk voor informatiesystemen, besluitvormingsanalyses en planning support tools geconceptualiseerd, dat toepasbaar is bij risicomanagement in een typische industriële stad in India. Vier systemen zijn ontworpen en ontwikkeld als onderdeel van dit onderzoek.

Risk Management Information System (RMIS): Het RMIS is ontworpen als basisinformatie management platform en verschaft analytische functionaliteiten voor besluitvormers als ook relevante informatie voor belanghebbenden via een web-GIS interface. Doorontwikkeld op basis van de doelstellingen van het ERRIS project, is in het RMIS ontwerp uitgegaan van een inter-operationeel en context-gevoelig SDI raamwerk met informatie diensten die in staat zijn verscheidene databronnen te integreren en te delen. Het systeem concept houdt rekening met consolidatie van informatie over industriële risicobronnen, risico-aspecten en kwetsbaarheden, andere planning gerelateerde informatiebehoeften, en real time informatie via sensoren.

Het RMIS portal kan worden beschouwd als een op informatie gebaseerd DSS dat gerichte vragen over risico-informatie afhandelt, visualisaties maakt met kaarten, en uitvoer levert in de vorm van tabellen en grafieken van geanalyseerde data, en als zodanig kwalitatieve en numerieke informatie verschaft aan belanghebbenden gekoppeld aan hun directe behoeften. De RMIS functionaliteiten leveren ook alle informatie over regelingen en 
vereisten, die gevaarlijke industrieën dienen te overleggen aan regelgevende instanties, of belanghebbenden die onderhevig kunnen zijn aan de gevolgen van industriële ongelukken. Indien verder ontwikkeld heeft het systeem potentie om waardevolle informatie toe te voegen zoals risicokaarten voor industriële gebieden die kunnen worden gebruikt door verzekeringsmaatschappijen om premies vast te stellen of door burgers als zij van plan zijn een huis te kopen.

Als tweede toepassing is het Emergency Decision Support System (EDSS) ontworpen met het doel om besluitvorming te ondersteunen bij acute industriële rampenplanning en rampenbestrijding. Kernpunten in het conceptontwerp vormen de moeilijkheden die men tegenkomt om een breed scala aan informatie uit verschillende bronnen te consolideren ten behoeve van de planning en bestrijding van een industriële ramp, en de noodzaak tot snelle besluitvorming. Met behulp van een interface voor visualisatie en informatieverspreiding verschaft het belanghebbenden de benodigde informatie zodat geschikte preventieve en beschermende acties kunnen worden ondernomen om schade en letsel voor kwetsbare burgers te beperken. Essentieel voordeel van het EDSS is dat het besluitvormers de mogelijkheid verschaft om te handelen op basis van actuele informatie, om potentiële gevolgen via dynamisch modellering in te schatten, en een "reëel noodplan" te produceren in overeenstemming met de regelingen en in plaats van een papieren plan. Reviews hebben aangetoond dat papieren plannen aangeleverd door regelgevende organisaties vaak verouderd zijn of vitale informatie missen die rampenorganisatie en -bestrijders nodig hebben als de ramp zich voordoet. Het voordeel van gebruik van een IT oplossing voor rampenbestrijding is de mogelijkheid om informatie van online sensoren te integreren zodat een actueel beeld kan worden verkregen van zaken als de overheersende windrichting of de posities van rampbestrijders.

De derde component van het system is de kwantitatieve risico-evaluatie tool (QRA Risk Mapper). Momenteel is er geen gestandaardiseerde of consistente methodologie voorhanden die kan worden gebruikt door regelgevende organisaties, de industrie of andere belanghebbenden om risico's te schatten op gebiedsniveau bij een gevaarlijk industrieel complex. De QRA Risk Mapper kan leiden tot de vaststelling van een geharmoniseerde methodologie voor het schatten van risico's, die kan worden toegepast en gedeeld in een gedistribueerd system, en de noodzakelijke ondersteuning biedt voor de beheersing van risico's via een raamwerk van regelingen en planning. De QRA Risk Mapper is ontwikkeld vanuit de optiek dat het synchroon loopt met de informatie over ongeval en kwetsbaarheden vanuit de RMIS database, en dat het deze informatie integreert met rekenmodellen en -tools om een cumulatieve risicokaart van een gebied te maken. Gebaseerd op visualisatie van risiconiveaus met een resolutie van een $100 \mathrm{~m}$ grid, kunnen beslissingen 
op het gebied van ruimtelijke planning worden gemaakt ten aanzien van welke locaties kunnen worden bestemd voor een nieuwe risicovolle industriële activiteit, of voor woonbestemming of commerciële activiteiten in een bestaande industriële stad.

De vierde component is een Planning Support System voor Risk Guided Land Use Planning. India is getuige van een zeer snelle economische ontwikkeling en heeft een hoge bevolkingsdichtheid, waardoor stedelijke planners geconfronteerd worden met conflicterende belangen als het gaat om de geschiktheid van land voor ofwel verdere ontwikkeling van industriële activiteiten ofwel de behoeften van burgers met betrekking tot huisvesting of recreatie. Het Multi Criteria Evaluatie PSS ondersteunt ruimtelijke ordening op lokaal niveau door gebruik te maken van indicatoren, waarbij indicatoren betreffende risico's en kwetsbaarheden via een multicriteria analyse leidend kunnen zijn voor voorstellen voor toekomstig landgebruik. Het PSS ontwerp is geschikt voor een participatieve aanpak via de system interface en discussies onder belanghebbenden, en kan leiden tot alternatieve planning scenario's. Het is de verwachting dat ondersteunende systemen als MCE-PSS zullen worden gebruikt om te komen tot zogenaamde 'land utilization zones' (LUZs) en 'land use management areas' (LMAs) in overeenstemming met het concept National Land Utilization Policy zoals geformuleerd door de overheid van India.

De mate van succes van deze systemen hangt af van verscheidene factoren: onder andere de realisatie van mechanismen om belangrijke risicogerelateerde data actueel te houden met behulp van de functionaliteiten in het systeem, het op geschikte wijze delen van gegevens via SDI platforms, overeenstemming over risico-evaluatie methoden en modellen die de kern vormen van het beslissingsondersteunend systeem en tenslotte adequate training van actoren en andere potentiële gebruikers waardoor het systeem aan acceptatie kan winnen. Naar verwachting behoeft het systeem voortgaande kalibratie en verfijning, als het door gebruikers wordt toegepast en getoetst.

De evaluatie van de informatie-, besluitvormings- en planning tools door potentiële domein experts en gebruikersgroepen vormt een belangrijke sleutel tot het succes van de tools. Verscheidene methoden zijn geformuleerd om te evalueren en te testen of het beslissing- en planning-ondersteunend systeem in staat is om geschikte hulp te bieden in een specifieke situationele context. Dit onderzoek had slechts beperkte mogelijkheden om de ontworpen en ontwikkelde systemen te evalueren. Een beperkte formele test van het EDSS en de QRA Risk Mapper is uitgevoerd als onderdeel van een nationale workshop waaraan gebruikers uit verschillende staten deelnamen en 
feedback gaven via een speciaal ontwikkelde enquête, na te zijn getraind in het gebruik van het systeem.

Dit onderzoek poogt een brug te vormen tussen ITC toepassingen en het domein van industrieel risicomanagement in India. Naar verwachting zal de conceptualisatie en het ontwerp van de verzameling van informatie-, besluitvormings- en planning tools in dit onderzoek aanleiding vormen voor een voortschrijdende onderzoek interesse in India ten aanzien van hoe beleid aangaande industriële risico's, regelingen en methoden kunnen worden geformuleerd en toegepast in de praktijk met het uiteindelijke doel om India veiliger te maken. Tenslotte kan de verkenning van mogelijkheden voor toepassing van deze systemen op grotere schaal leiden tot vervolgonderzoek om deze systemen verder te verfijnen en aan te passen. 


\section{Acknowledgements}

This research started in an interesting manner - working as a young consultant at the beginning of my career, there was this urge to make my educational background in environmental management meet with that of information systems. An opportunity for this arose when in 2004 the idea of the Environmental Risk Reporting and Information System (ERRIS) was conceived with funding support from the European Commission. Subsequently in 2004, a collaboration for implementing the objectives of the project could be worked out with the then International Institute of Geoinformation Science and Earth Observation (ITC) and the Institute for Protection and Safety of the Citizens (IPSC). It was in course of implementation of this project and during my first visit to ITC for a training course on disaster risk management in 2004, the initial discussions for further research on the topic was held with John Horn, the Project Coordinator and Cees van Westen, Technical Advisor to the ERRIS project. Couple of years later, when the project was completed in 2006, the contours for further research could be agreed upon leading to further planning of my PhD journey. So, at first, I would like to express my gratitude to ITC for considering this topic for $\mathrm{PhD}$ research and supporting me through the scholarship programme. Special thanks go to John and Cees for encouraging me to make this choice as a working professional.

Several other institutions have been supportive of this research - the Indian Chamber of Commerce based in Kolkata, the National Institute of Disaster Management and the Haldia Development Authority in India needs special mention for providing me with valuable suggestions and practical insights on issues related to my research objectives. Importantly, they also provided me with platforms for engaging with stakeholders, decision makers and planners to be able to test my hypothesis and seek their feedback.

Commencing research at ITC, I benefited immensely from the long and intense discussions I had with Prof. Anne van der Veen. We often discussed on how risk is a 'wicked problem' and exchanged ideas on how to capture the key elements of risk governance into information, decision and planning support systems. He also positively critiqued my style of academic writing and provided the necessary push to carry on, when required. I would like to kindly acknowledge that this thesis has gained immensely from his valuable mentorship. A sincere word of appreciation to my co-promoters - but for their patience as well as the motivation and continuous guidance that they offered, I would not have made it to this stage. Thanks to Cees for being involved in this research from the ERRIS project days and for helping me to manoeuvre the sometimes arduous and long PhD path. Johannes Flacke did open up new windows on decision and planning support systems by inviting me to join a 
course on SDSS in the initial days of research and has since stood firmly beside me until this point. Earnest thanks to Prof. Martin van Maarseveen for agreeing to promote me for the $\mathrm{PhD}$ and for providing constructive suggestions during finalisation of the thesis.

Several components of this research have taken shape because of team efforts. With Anandita, I had the opportunity of teaming up since the ERRIS project when she started working as a colleague and from whom I have gained considerable insights on spatial analysis methods and techniques thanks for the close collaboration on this PhD journey! The prototype systems developed as a part of this research would not have been possible without the programming support from three of my colleagues - Nilanjan, Sumon and Joydeep. Since the days of working closely on the ERRIS, this has continued to be an ongoing project of common interest to all of us and we have a goal to pursue it further as we work ahead. And of course, my other PhD colleagues and friends, especially colleagues at room number 3030 with whom the long and intense discussions were indeed productive and fun - so thank you Moses, Rafael, Armindo, Divyani, Rishi, Gaurav, Saibal, Maitreyi and others.

Working out of ITC as a part of the sandwich PhD program and my stays at ITC International Hotel has always been a smooth and enjoyable experience. It would not have been that way if not for the administrative support and cooperation that I received, in particular from Loes, Petra, Saskia, Marion and in general, from everyone else I met at ITC - all of you have ensured that Enschede remains a pleasant memory and a slice of Dutch culture stays with me going forward in life.

Last but not the least; I valued all through this journey the support of my entire family. Specifically, my wife Jayita patiently weathered the innumerable missed weekends while I worked on my research and my mother Nilima for continuing to exhibit such deep trust in my ability to reach the PhD finish line. Finally, our daughter Debjeeta who missed me at home during an early age and now in middle school often, somewhat embarrassingly, posed this question to me: "Baba, when would you finally finish your studies?" - I can now happily pass on the baton to her so that she can continue the run in pursuit of higher education. 


\section{Table of Contents}

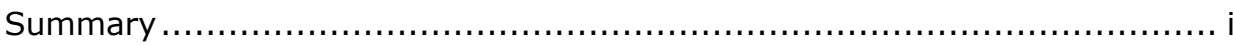

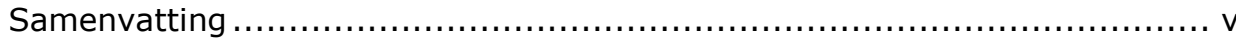

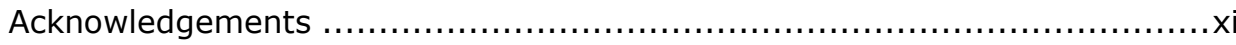

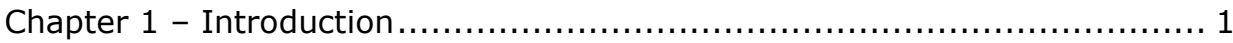

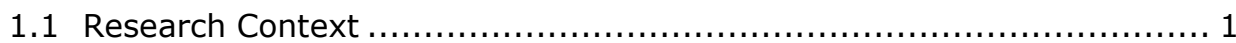

1.2 Research Problem.......................................................... 2

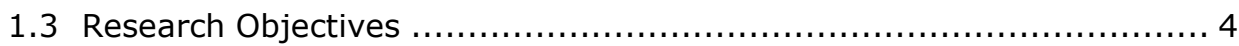

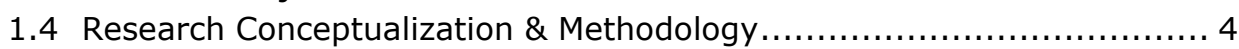

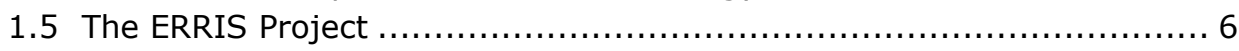

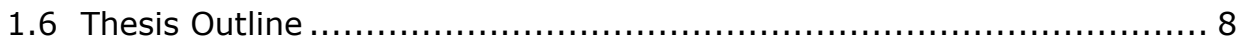

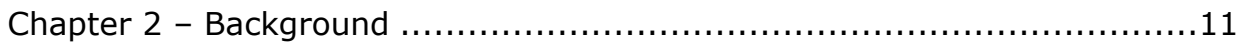

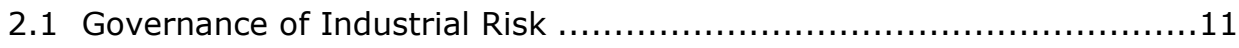

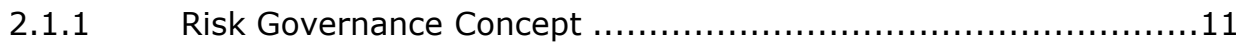

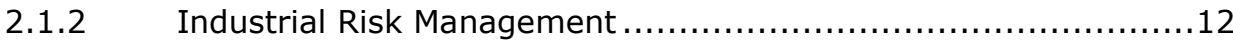

2.1.3 Risk Decision Making - Emergency Preparedness and Response

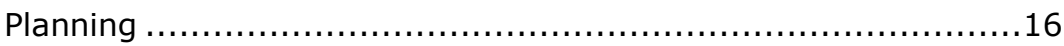

2.1.4 Risk Decision Making - Land Use Planning .......................17

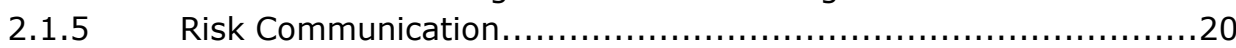

2.2 Risk Information, Decision and Planning Support Systems - A Review .21

2.2.1 Progress of Decision \& Planning Support Systems - Recent Developments ................................................ 21

2.2.2 Present Applications of DSS \& PSS in the Domain of Risk Management ..................................................... 27

2.2.3 Use \& Effectiveness of Decision \& Planning Support Tools ..........30

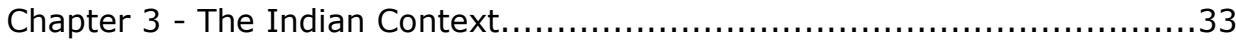

3.1 Policy, Regulatory and Institutional Context ............................. 33

3.1.1 Policy Framework for Industrial Risk ........................... 33

3.1.2 Regulatory Framework for Industrial Risks ...................... 34

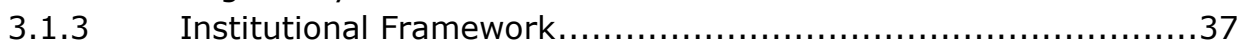

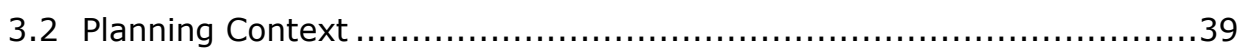

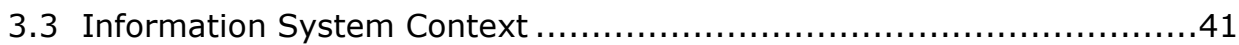

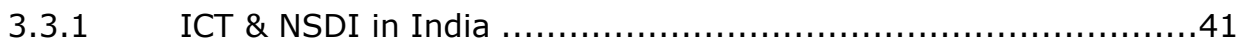

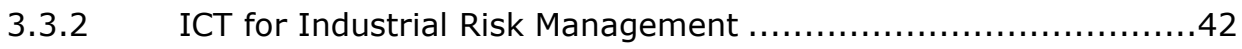

3.4 Case Study Area - Haldia ..........................................43

Chapter 4 - The Industrial Risk Management Information System ...........47

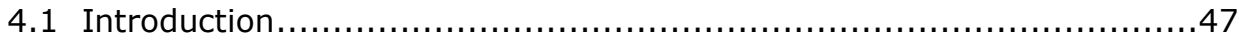

4.2 Framework for Industrial Risk Management Information .................48

4.2.1 Industrial Risk Governance \& Information Requirements..........48

4.2.2 Conceptualizing the Industrial Risk Geo-portal and SDI ...........50

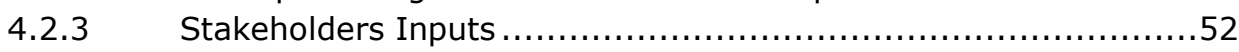

4.2.4 Use Case for Industrial Risk Management .......................... 56

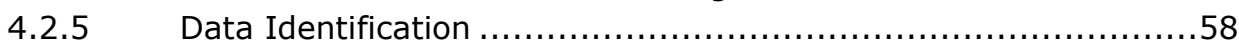


4.2.6 Data Model for Industrial Risk Management ......................66

4.3 Design and Implementation of the RMIS ..............................69

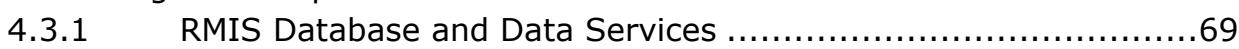

4.3.2 System Architecture................................................ 71

4.4 Demonstration of Prototype RMIS .................................... 74

4.4.1 Querying Information and Maps................................. 74

4.4.2 Adding, Viewing and Updating Information........................ 76

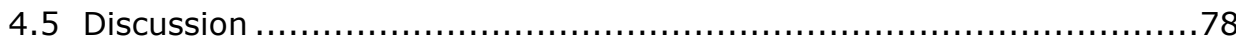

Chapter 5 - Emergency DSS to Aid Management of Industrial Accidents......81

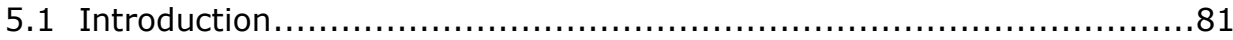

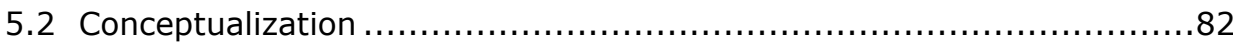

5.2.1 Emergency DSS Framework ....................................... 82

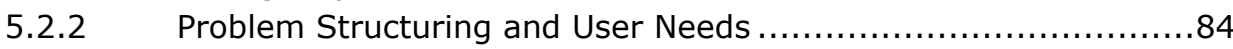

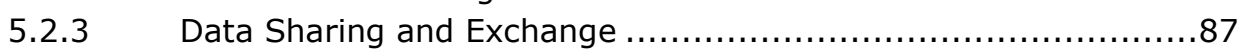

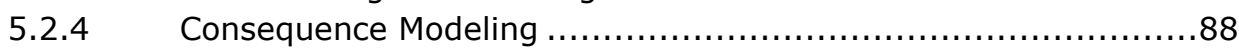

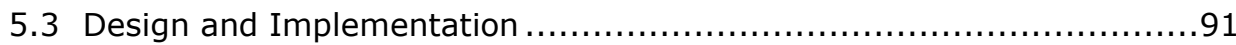

5.3.1 Information Service and Knowledge Base ...................... 91

5.3.2 Workflow Modeling ............................................. 93

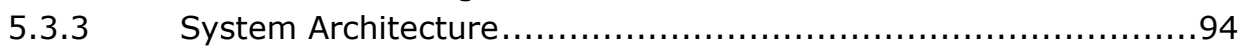

5.3.4 User Interface and Visualization................................. 95

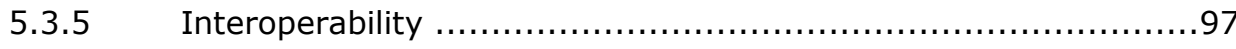

5.4 Demonstration of Prototype Emergency DSS .......................... 98

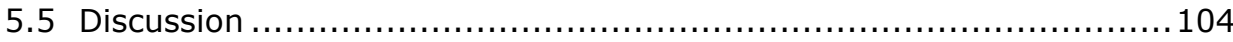

Chapter 6- QRA Risk Mapper Tool for Estimating Industrial Risk .............. 107

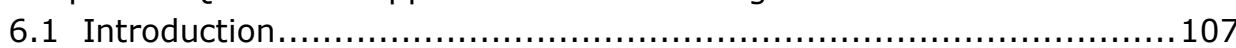

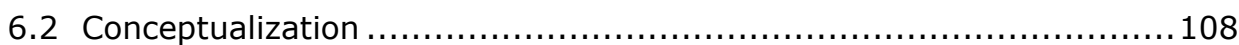

6.2.1 Scenario Based Industrial Risk Assessment ...................... 108

6.2.2 Standardization of QRA Risk Assessment ...................... 111

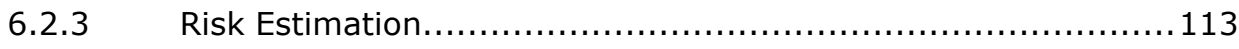

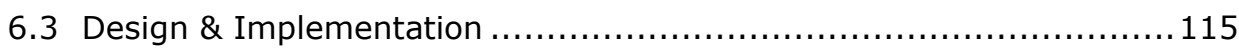

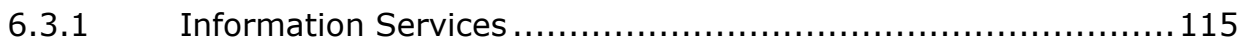

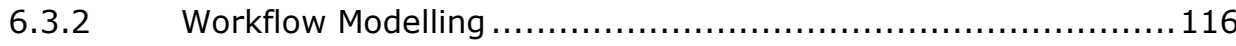

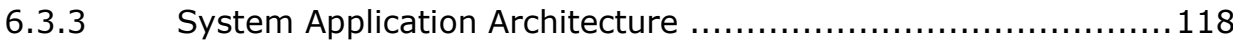

6.3.4 User Interfaces and Visualization ................................. 119

6.4 Demonstration of Prototype Risk Mapper ............................ 122

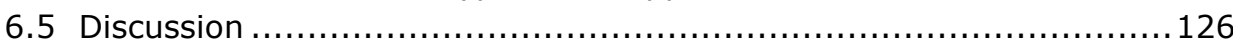

Chapter 7 - PSS for Risk Guided LU Planning ............................. 129

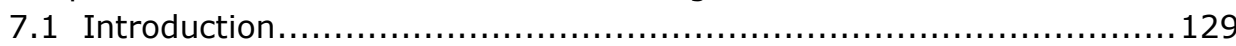

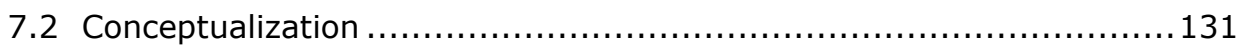

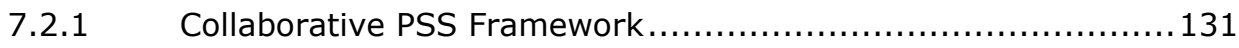

7.2.2 MCE Approach and Methodology .................................. 134

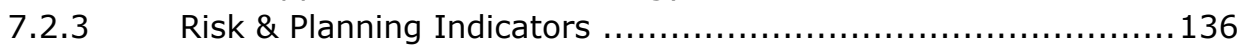

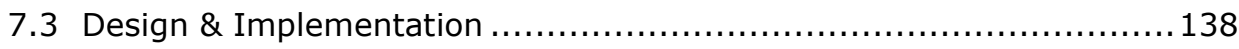

7.3.1 PSS Design and Analysis Workshop ........................... 138 
7.3.2 Data \& Indicator Preparation ............................................. 140

7.3.3 SMCE Modelling Toolbox and Application Architecture..............142

7.3.4 Visualization and Interface ............................................. 144

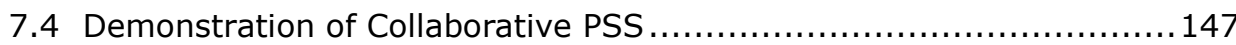

7.4.1 Indicator Based Risk Mapping....................................... 148

7.4.2 Suitability Analysis and Mapping ...................................... 149

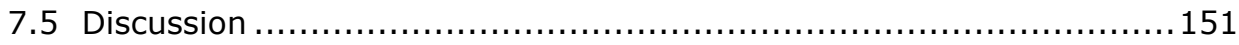

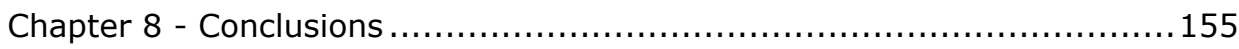

8.1 Consolidation of Conceptual and Methodological Framework .............155

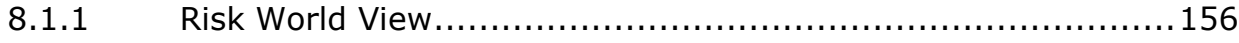

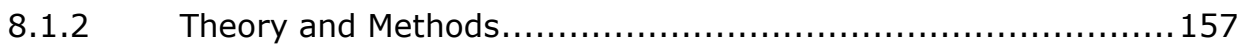

8.1.3 Decision \& Planning Support ......................................... 157

8.1.4 Use and Effectiveness................................................... 160

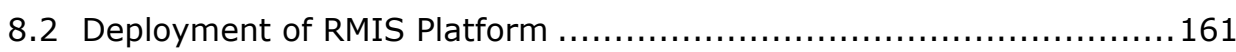

8.3 Future Research .................................................................. 162

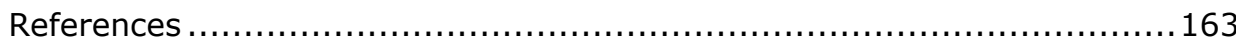

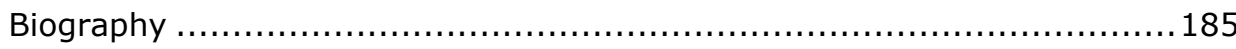

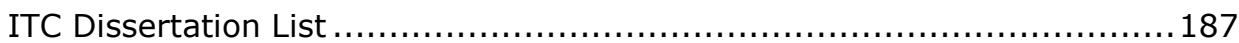




\section{Abbreviations}

\begin{tabular}{|c|c|}
\hline ALARP & As Low As Reasonably Practicable \\
\hline ALARA & As Low As Reasonably Achievable \\
\hline API & Application Programming Interface \\
\hline BLEVE & Boiling Liquid Expanding Vapour Explosion \\
\hline СОМАН & $\begin{array}{l}\text { Control of Major Accident Hazards involving Dangerous } \\
\text { Substances Regulation - UK }\end{array}$ \\
\hline CPCB & Central Pollution Control Board - India \\
\hline DCDB & Digital Cadastre Database \\
\hline DECERNS & $\begin{array}{l}\text { Decision Evaluation for Complex Environmental Risk } \\
\text { Network Systems }\end{array}$ \\
\hline DERMIS & $\begin{array}{l}\text { Dynamic Emergency Response Management Information } \\
\text { System }\end{array}$ \\
\hline DGFASLI & $\begin{array}{l}\text { Directorate General Factory Advice and Labour Institutes - } \\
\text { India }\end{array}$ \\
\hline DMP & Disaster Management Policy (2006) - India \\
\hline DRI & Disaster Risk Index \\
\hline DSS & Decision Support System \\
\hline DST & Department of Science and Technology - India \\
\hline EDSS & Emergency Decision Support System \\
\hline EIA & Environmental Impact Assessment \\
\hline EIIFXG & Emergency Information Framework \\
\hline EPCRA & $\begin{array}{l}\text { Emergency Planning and Community Right to Know } \\
\text { Regulation - US }\end{array}$ \\
\hline EPPRCA & $\begin{array}{l}\text { Emergency Planning, Preparedness and Response to } \\
\text { Chemical Accident Rules (1996) - India }\end{array}$ \\
\hline EPRG & Emergency Response Planning Guidelines - US \\
\hline ERC & Emergency Response Centre \\
\hline ERDMP & $\begin{array}{l}\text { Emergency Response \& Disaster Management Planning } \\
\text { (guidelines) - India }\end{array}$ \\
\hline ERRIS & Environmental Risk Reporting and Information System \\
\hline Geo-DSS & Geographical Decision Support System \\
\hline GEPR & GIS based Emergency Preparedness and Response - India \\
\hline GML & Geographical Mark-up Language \\
\hline GPS & Global Positioning System \\
\hline GWR & Geographically Weighted Regression \\
\hline HDA & $\begin{array}{l}\text { Haldia Development Authority, Haldia (local planning } \\
\text { authority) - India }\end{array}$ \\
\hline HSE & The Health and Safety Executive - UK \\
\hline HSMD & $\begin{array}{l}\text { Hazardous Substance Management Division, MoEFCC - } \\
\text { India }\end{array}$ \\
\hline
\end{tabular}




\begin{tabular}{|c|c|}
\hline ICT & Information and Communication Technology \\
\hline IR & Individual Risk \\
\hline IRGC & International Risk Governance Council \\
\hline IRIMS & Ispra Risk Information Management System \\
\hline IRM-SDI & Industrial Risk Management - Spatial Data Infrastructure \\
\hline ISDR & International Strategy for Disaster Reduction \\
\hline ISRO & Indian Space Research Organisation \\
\hline KML & Keyhole Mark-up Language \\
\hline LEPC & Local Emergency Planning Committee - India \\
\hline LMAs & Land Management Area(s) \\
\hline LPG & Liquefied Petroleum Gas \\
\hline LUDCP & Land Use Development Control Plan - India \\
\hline LUPAC & Land use planning and chemical sites \\
\hline LUZ & Land Use Zones \\
\hline MAAS & Models As A Service \\
\hline MADM & Multi-attribute Decision Making (approach) \\
\hline MAH & Maximum Accident Hazard \\
\hline MCA & Multi-Criteria Analysis \\
\hline MoEFCC & $\begin{array}{l}\text { Ministry of Environment, Forests and Climate Change - } \\
\text { India }\end{array}$ \\
\hline MSDS & Material Safety Data Sheet \\
\hline MSIHC & $\begin{array}{l}\text { Manufacture Storage and Import of Hazardous Chemical } \\
\text { Rules (2000) - India }\end{array}$ \\
\hline NDMA & National Disaster Management Authority - India \\
\hline NEP & National Environment Policy (2006) - India \\
\hline NIDM & National Institute of Disaster Management - India \\
\hline $\mathrm{NIOSH}$ & $\begin{array}{l}\text { National Institute for Occupational Safety and Health - } \\
\text { United States }\end{array}$ \\
\hline NNMRS & National Natural Resources Management System - India \\
\hline NRDMS & Natural Resources Data Management System - India \\
\hline NSDI & National Spatial Data Infrastructure - India \\
\hline NUIS & National Urban Information System - India \\
\hline OGC & Open Geospatial Consortium \\
\hline OISD & Oil Industry Safety Directorate - India \\
\hline OWS & OGC Web Services \\
\hline PADHI & $\begin{array}{l}\text { Planning Advice for Developments near Hazardous } \\
\text { Installations - UK }\end{array}$ \\
\hline PESO & Petroleum and Explosives Safety Organisation - India \\
\hline PLL & Potential Loss of Life \\
\hline PNRGB & Petroleum and Natural Gas Regulatory Board - India \\
\hline PSS & Planning Support System \\
\hline QRA & Quantitative Risk Assessment \\
\hline
\end{tabular}




$\begin{array}{ll}\text { RDBMS } & \text { Relational Database Management System } \\ \text { REST } & \text { Representational State Transfer (protocol) } \\ \text { RMIS } & \text { Risk Management Information System } \\ \text { SAW } & \text { Simple Additive Weighting } \\ \text { SDI } & \text { Spatial Data Infrastructure } \\ \text { SDLC } & \text { Software Development Life Cycle } \\ \text { SDSS } & \text { Spatial Decision Support System } \\ \text { SMCE } & \text { Spatial Multi-Criteria Evaluation } \\ \text { SoA } & \text { Service oriented Architecture } \\ \text { SOI } & \text { Survey of India } \\ \text { SPCB } & \text { State Pollution Control Board - India } \\ \text { SQL } & \text { Standard Query Language } \\ \text { SR } & \text { Societal Risk } \\ \text { UAV } & \text { Unmanned Aerial Vehicle } \\ \text { UML } & \text { Unified Modelling Languages } \\ \text { UNDP } & \text { United Nations Development Program } \\ \text { VCE } & \text { Vapour Cloud Explosion } \\ \text { WCS } & \text { Web Coverage Service } \\ \text { Web-GIS } & \text { Web (based) Geographic Information System } \\ \text { WFS } & \text { Web Feature Service } \\ \text { WLC } & \text { Weighted Linear Combination } \\ \text { WMS } & \text { Web Map Service } \\ \text { WSDL } & \text { Web Services Description Language } \\ \text { WSN } & \text { Web Sensor Network } \\ \text { VCE } & \text { Vapour Cloud Explosion } \\ \text { VHR } & \text { Very High Resolution (imagery) } \\ \text { XML } & \\ \text { XSLT } & \text { Extensible Mark-up Language } \\ & \end{array}$




\section{Chapter 1 - Introduction}

This introductory chapter begins with an initial discussion on the context of this research, explaining in brief the background on risk governance and trends in research in online geospatial information, decision support and planning systems. Subsequent sections discuss the research problems, objectives, methods and present a brief description of the ERRIS project, which led to the formulation of this research.

\subsection{Research Context}

In the night of December $2^{\text {nd }}, 1983$, highly toxic methyl iso-cyanate (MIC) gas leaked from the Union Carbide pesticide-manufacturing plant located at the heart of the Indian town of Bhopal. Overnight, more than 3,000 people in the surroundings of the plant died after inhaling the gas and many more died in subsequent days and weeks. The exact number of deaths was contested with some estimates going up to 20,000. Bhopal was a watershed event and qualifies as one of the worst manmade disasters that the world has witnessed to this day (Ayres et al., 1987; Chouhan, 2005). The immense loss caused by the incident, triggered a worldwide reappraisal on industrial risk management with a number of countries taking proactive steps to establish more stringent management control over hazardous industries. Although, considerable progress have been made worldwide, many densely populated countries, which are witnessing rapid industrial development, still lag behind in efforts to reduce industrial risk. This calls for more focussed action to make sure that events like Bhopal are not repeated.

The evaluation of hazards and related decision making to minimise industrial risk is a complicated and often laborious task. This can be attributed to the compound interrelations between risk factors, lack of proper understanding of the processes that may result in damages and complexity of the physical and social systems involved in risk management (UN, 2007). Risk related to industrial accidents may have better manageability than natural-hazard risk as the occurrence of accidents can be prevented through adoption of appropriate safeguards and potential losses to human life and property can be reduced through proper planning (Radke et al., 2000). However, major disasters such as Bhopal, Chernobyl and Seveso have shown that dealing with such industrial risks involves considerable challenges, even in the $21^{\text {st }}$ century. In "World Risk Society", the social researcher Ulrich Beck describes the situation today as a society where in spite of living on the edge of high industrial innovation and scientific development, we do not fully comprehend potential risk in the form of industrial, chemical and nuclear dangers that confront us (Beck, 1999). 
In light of significant damages caused by the Seveso accident in Italy and other events like that of Bhopal and Mexico City, which occurred in quick succession during the 1980s, the urgency to implement regulatory regimes for managing industrial risk was felt by many countries. Countries in Europe where industrial developments have long co-existed with densely populated areas, made significant progress in formulating policies, regulations and planning frameworks to deal with the issue of industrial risk. The Seveso Directive in the European Union provides overall guidance to regulate the chemical industry in order to prevent accidents (Versluis et al., 2010). It is a good example of goal-setting regulation and contains general and specific obligations for operators and authorities related to the prevention of major accidents and limitation of their consequences (EC, 1996).

In an effort to ensure that the regulatory requirements are adhered to, the use of risk management tools guided by science-based risk assessment methods became popular. The first efforts in this direction were made in the mid-1900s to understand the safety and hazard aspects of space vehicle launches, nuclear power stations and chemical facilities (Löfstedt et al., 2009). Since then, with the objective of regulating risk, several methods for industrial risk assessment have been formulated and put into practice. They range from quantitative and probabilistic to qualitative and hybrid methodologies (Marhavilas et al., 2011; Pasman et al., 2014). However, there has also been a lot of criticism on purely science-driven approaches, given the complexity of decision making and the uncertainty surrounding the prediction of a risk event often leading to reservations about such approaches amongst stakeholders (Stern et al., 1996). Especially for non- technical stakeholders, it is difficult to understand the reasons for certain conclusions reached through such scientific approaches. For example, many Dutch local authorities and citizens in general have questioned the decision not to allow residential houses in the Netherlands in areas having Individual Risk value of $<10^{-6}$ (per year) (Ale, 2002; Bottelberghs, 2000).

\subsection{Research Problem}

Though, many emerging nations continue to witness an amplification of risk because of rapid industrialisation, often in areas having high population vulnerability, risk management still remains restricted to the technical domain and lack stakeholder consensus in risk related decision making (Porto et al., 1996). In India for example, a national level review of chemical risk management practice provided pointers to a number of key deficits with regard to regulatory compliance by hazardous facilities, risk assessment methods, emergency planning and preparedness and information availability with stakeholders (GoI:NDMA, 2007). Therefore, in order to develop coherent and robust strategies for risk governance, there is a need for research at the 
country level on several aspects of industrial risk management. They include the governance approach to risk management, methods for risk assessment ${ }^{1}$, stakeholder engagement and the design and implementation of appropriate information and communication technology (ICT) based decision support tools.

Knowledge and innovation has a key role to play in order to build a culture of safety and resilience to different kinds of disasters (ISDR, 2005). Policy makers in India have recognized the need for moving towards a proactive approach, focusing more on pre-disaster prevention and preparedness as compared to the earlier post-disaster mitigation and relief-based approach (GoI:MoHA, 2009). They also indicated the need to enhance information sharing and management amongst a network of government agencies and institutions in order to create a common knowledge platform (MoHA:GoI, 2004). However, the reality on the ground has demonstrated on multiple occasions that sharing of information to support rational and effective decision making continues to be a weak link in the disaster management chain in India.

The key problems in industrial risk management in India that the research would aim to address are the following:

- lack of an appropriate platform for aggregating and sharing information about industrial hazards, vulnerabilities and risk, amongst stakeholders such as government departments, private sector, community and civil defence;

- lack of appropriate and standardized methodologies for industrial risk analysis in different stages of the risk management process;

- lack of computerized tools which, using standardized methodologies, can help in processing existing information and knowledge, thereby providing guidance to risk actors in decision making and planning;

- lack of appropriate mechanisms that can promote participatory and transparent decision making on industrial risk amongst stakeholders;

- lack of understanding of ICT based information, decision and planning support tools and their utility amongst stakeholders.

This calls for new research efforts to deal with the complexity and uncertainty of industrial risk decisions in an informed and transparent manner.

\footnotetext{
${ }_{1}^{1}$ Methods for industrial risk assessment in the Indian context are discussed in a complementary PhD thesis: Sengupta, A. "Industrial Risk Assessment - Indian Perspective", 2016.
} 


\subsection{Research Objectives}

The main objective of this research is to design and develop an online platform that can support decision makers on different aspects of industrial risk management, focusing on the specific situation in India.

In order to achieve this objective, the following sub-objectives have been formulated:

- Conceptualise a flexible framework for information systems, decision analysis and planning support tools focusing on the domain of industrial risk, applicable for risk governance of a typical industrial town in India, accounting for local level planning and institutional capacities, availability of information and stakeholder needs.

- Design and develop prototypes of service-oriented architecture (SoA) based:

- Information Support System to collect, manage and share information related to industrial installations, vulnerable elements at risk, accident scenarios, and risk among different stakeholders;

- Decision Support System to aid emergency management for industrial accidents;

- Decision Support System for quantitative risk assessment;

- Planning support system for risk-guided land use planning;

- Demonstrate the applicability of the prototype systems using available information and simulating needs of local level administration, planners and stakeholders in an industrial town in India (Haldia).

- Undertake a preliminary assessment of the effectiveness of systems through a group-based evaluation exercise.

\subsection{Research Conceptualization \& Methodology}

It is well recognised that decision-support tools should be conceptualised and developed in light of a realistic implementation rationale and use context, with due understanding of the needs of potential users and stakeholders. The approach for this research uses an adaptation of the conceptual framework formulated by Liebowitz (1997) for developing expert systems and is shown in Figure 1-1. 


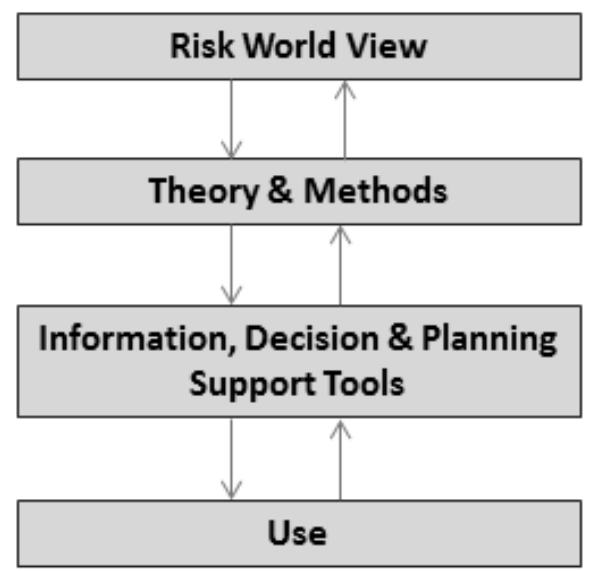

Figure 1-1: Research Approach

The top layer of the framework refers to the overall set of principles and assumptions about governance, information availability and stakeholder decision-making needs in the domain of risk management. In the process of conceptualising, developing and testing the tools as a part of this research, an understanding was obtained through review of existing policies, regulations and institutional setups for governance of industrial risk prevailing in India. Several workshops and meetings with stakeholders were undertaken as a part of this research and as a part of the pre-cursor project called the Environmental Risk Reporting and Information System (ERRIS), to understand the problems faced by decision makers and stakeholders.

The second tier in the framework refers to the underlying set of theories and methods on industrial risk assessment, evaluation and its application to planning, as has been developed and applied in other parts of the world, especially in Europe. The theory and methods for industrial risk assessment in the Indian context are discussed in detail in a complementary thesis by Sengupta (2016). A review of scientific literature on spatial data infrastructures (SDIs), decision and planning support systems and their current progress has been undertaken to be able to identify and adapt them to the Indian governance setup for risk management.

The third methodological step involved the conceptualisation, design and development of a 'cloud' based information system framework for industrial risk management in India as well as prototype decision and planning support systems for emergency management, cumulative risk assessment and for risk-based land use suitability analysis. The prototype systems have been 
demonstrated to function with real life data and information for the industrial town of Haldia, India.

The fourth step of the framework attempts to assess if the prototype systems are meeting the needs of the target audience and to devise methods that can evaluate the effectiveness and efficiency of the systems, so that recommendations for future improvements can be provided through a feedback loop to the system design and development process.

Based on this conceptual methodology, a more detailed and focussed lifecycle based approach represented by 'boxes' denoting activities and 'arrows' linking these activities have been used for each of the tools developed as a part of this research and this is represented in Figure 1-2.

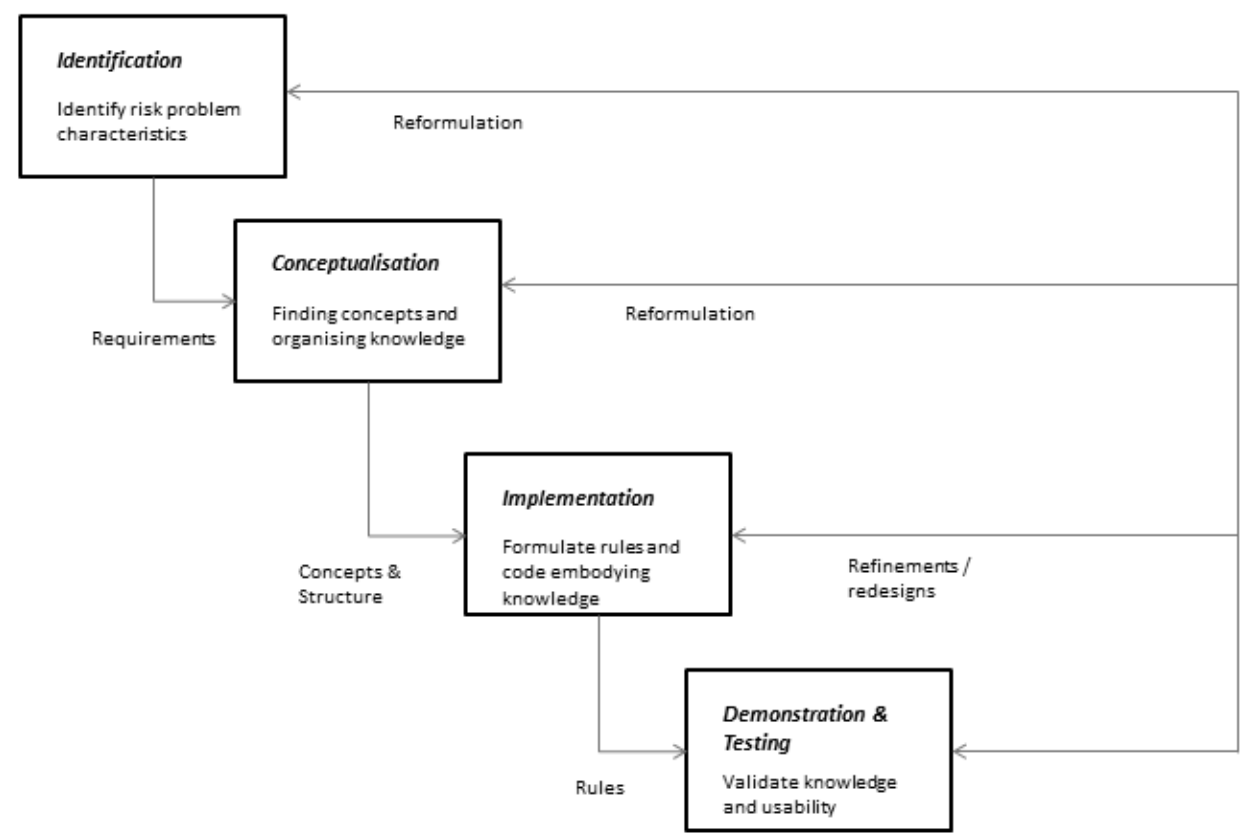

Figure 1-2: Waterfall Model based Software Development Lifecycle (SDLC) for Design and Development of Prototypes

\subsection{The ERRIS Project}

The research emerges from the Environmental Risk Reporting and Information System (ERRIS) project, which was implemented as a Corporate Social Responsibility initiative for hazardous industries in the industrial towns of Haldia and Durgapur in the State of West Bengal, India. ERRIS was initiated by the Indian Chamber of Commerce, an industry organisation along with partners in Europe - the then International Institute of Geo-information 
Science and Earth Observation (ITC), Netherlands and the Institute for Protection and Security of Citizens (IPSC), a part of the Major Accident Hazards Bureau (MAHB), Joint Research Centre (JRC), Italy. The project was supported by the European Commission. At the time of conception, there was no integrated ICT solution in India that could reinforce and consolidate industrial risk management activities through better sharing of information, thereby providing crucial guidance for informed decision making to several risk actors.

The project had two key objectives. The first was to set up a structured mechanism for voluntary reporting of risk-related information by potentially hazardous industries in Haldia and Durgapur. The second objective was to establish a computerized and collective web-GIS based information system for management of industrial risks. The ERRIS project presented an integrated approach to the management of industrial hazards in which industry management, decision makers and government officials can make use of a web-GIS tool to obtain information on the hazards present within the industries, nature of chemicals, process details, site maps and internal emergency management resources.

The ERRIS information system had two key components. General information about the industry and specifically pertaining to major hazards originating from it included details of the storages, nature of chemicals, safety measures present with the facility, and was stored in a relational database through a Risk Reporting System (RRS). The industries could add information on new storages or modify existing information. Authenticated and filtered access to the above information was provided to each industry through a secured login to the system, so that the identified industry representatives could periodically update data. In addition, detailed attribute information on elements at risk was also stored in the RDBMS and linked to spatial features to enable querying during emergency planning, preparedness, response and mitigation. The other component, the online Risk Information System (RIS) was a custom-designed web-GIS interface for viewing and querying information. The RIS was capable of performing real-time data access, retrieval, and analysis, linked with spatial maps and back-end databases to answer specific queries. Information provided through the platform included the demarcation of high population risk areas related to the impact by a toxic release, fire or explosion at a hazardous facility, critical facilities like educational institutes, hospitals, market places and areas that are environmentally sensitive or have fragile ecosystems. The author of this PhD thesis played a key role in developing the software tools in the ERRIS project. After the end of the project, further research have been undertaken on these tools and the results are presented in this thesis. 
Overall, the aim of the project was to build a transparent framework for risk management by urging industries to proactively share information with various stakeholders thereby advancing the cause of responsible corporate citizenship in partnership with other social actors. Dialogue with stakeholders was considered an important aspect in achieving the objectives of the project. The ERRIS project partners carried out a need assessment study amongst various stakeholder groups in Haldia and Durgapur, in order to understand the level of awareness and perception that they have on industrial risk and get feedback on areas for which capacity building was required. Several stakeholder awareness and consultation programs were carried out, including structured workshops, focused group discussions, seminars and training programs. These interactions were received with considerable enthusiasm by a wide audience including political leadership, administrators, municipal councillors, industry management and employees, women's groups, doctors, citizen welfare associations, school teachers, nongovernment organisations and the citizens in general.

\subsection{Thesis Outline}

Following the introductory chapter, the thesis is structured into two parts:

- The first part aims to set a context for the research. Chapter 2 comprises of a literature review on relevant aspects related to industrial risk governance, risk assessment and decision-making. It also explores current research in the area of information, decision and planning support systems. Chapter 3 puts this generic picture in perspective of India by discussing the prevailing situation with respect to the industrial risk management framework and the progress in terms of ICT thus setting the context for specific decision and planning support systems to aid decision-making. This Chapter has common elements with the PhD thesis: Sengupta, A. "Industrial Risk Assessment - an Indian Perspective", 2016.

- The second part focuses on conceptualising the functionalities, methods for development and implementation techniques for several ICT based industrial risk management solutions. Chapter 4 explores a framework for a distributed Spatial Data Infrastructure based platform for acquiring and consolidating information related to industrial risk management that could serve as a foundation for a set of decision and planning support systems. The next three chapters comprises of discussions on decision and planning support systems by pursuing a line of enquiry into context specific decision-making problems. Chapter 5 discusses a decision support system for planning and response to industrial emergencies. Chapter 6 deals with a planning support system that can assist in 
undertaking summation and mapping of cumulative risk, leading to informed siting decisions. Chapter 7 focuses on a collaborative mechanism for risk guided land use planning using a multi-criteria evaluation based tool.

The final Chapter 8 provides a synthesis of the key issues in relation to information, decision and planning support for industrial risk management in India and provides an agenda for future research in the area. 


\section{Chapter 2 - Background}

This Chapter discusses literature and recent research in the areas of industrial risk governance and in ICT, decision and planning support systems and intends to provide a broad context to the research presented in the subsequent Chapters.

\subsection{Governance of Industrial Risk}

\subsubsection{Risk Governance Concept}

The practice of scientific risk assessment started in the late 1960s with the gradual realization that nuclear power plants, chemical industries and other progressive developments in technology are capable of posing substantial risk to humans and the environment, unless dealt with effectively (Löfstedt et al., 2009). Studies involving the social perspective of risk also evolved around the same time and at present, both these disciplines are now widely accepted to complement each other successfully. Social researchers like Beck (1999) have called for a new reference frame to better understand and treat the complexity associated with risk management in the modern world. This has led to a recent shift to pursue risk-related decision making through a broader frame of 'governance'.

The concept of viewing risk through the prism of governance is relatively new. On a national scale, governance describes structures and processes for collective decision-making, involving governmental and non-governmental actors (Nye et al., 2000). The term 'risk governance' is also relatively new and has gained popularity in policy studies and risk research thereby instituting a new approach to study the management of risk from a holistic point of view, encompassing the role of all the actors concerned in the process of risk management (van Asselt et al., 2011). Risk governance not only includes the traditional concepts covered in 'risk management' and 'risk analysis', but also accounts for the historical and legal backgrounds, guiding principles, value systems and the perspectives of several stakeholders who have an interest in risk decisions (IRGC, 2005).

According to the International Risk Governance Council (IRGC), risk governance includes "the totality of actors, rules, conventions, processes, and mechanisms concerned with how relevant risk information is collected, analysed and communicated and management decisions are taken". This philosophy of risk governance offers a major innovation - it emphasizes on better categorization of risk-related knowledge to guide societal decisions. Once a knowledge base is acquired and made available to risk actors, it can inform and guide scientific risk analysis through a formal process that links hazard sources with potential consequences and probability of occurrence of 
the hazard. The outcome of this evaluation can then aid in deciding on whether the risk is acceptable and if not, subsequently drawing up an action plan to reduce it to acceptable levels. In addition to the generic elements of risk, assessment, management and communication, the framework provides equal importance to contextual aspects which include the knowledge of stakeholders, their differing concerns and perceptions about risk and how they interplay as actors. Such an approach can help in the development of a risk governance philosophy and supporting policies that are guided by scientific rationale and result in a consistent and evidence based approach to solving industrial risk problems (Christou et al., 2011; McIntosh et al., 2011).

\subsubsection{Industrial Risk Management}

Worldwide, with an overall objective to improve risk governance, there are heightened efforts to mainstream risk considerations into short and long-term planning initiatives. The systematic assessment and evaluation of risk using scientific and normative methods are key to understanding risk and guide risk treatment and management actions. In order to obtain a better understanding, Table 2-1 provides brief definitions involving key terminologies associated with industrial risk assessment.

Table 2-1: Definitions of Risk with illustrative examples

\begin{tabular}{|c|c|c|}
\hline Term & Definitions & Illustrative Example \\
\hline $\begin{array}{l}\text { Industrial } \\
\text { Hazard }\end{array}$ & $\begin{array}{l}\text { A chemical or physical condition that } \\
\text { has the potential to cause damage to } \\
\text { people, property or the environment } \\
\text { or some combination of these. }\end{array}$ & $\begin{array}{l}\text { A refrigerated tank containing } \\
1000 \text { Metric Ton of Ammonia } \\
\left(\mathrm{NH}_{3}\right) \text {. }\end{array}$ \\
\hline $\begin{array}{l}\text { Major } \\
\text { Accident } \\
\text { Hazard (MAH) } \\
\text { industry }\end{array}$ & $\begin{array}{l}\text { A facility which stores a hazardous } \\
\text { chemical in excess of a threshold } \\
\text { quantity, as set in regulations. For } \\
\text { India, the threshold quantity is set in } \\
\text { the Schedule of the MSIHC Rules. }\end{array}$ & $\begin{array}{l}\text { A facility storing more than a } \\
\text { threshold quantity, say } 15 \mathrm{MT} \\
\text { of Ammonia }\left(\mathrm{NH}_{3}\right) \text {. }\end{array}$ \\
\hline $\begin{array}{l}\text { Hazard } \\
\text { Footprint or } \\
\text { Effect Zone }\end{array}$ & $\begin{array}{l}\text { For an incident which produces an } \\
\text { outcome (toxicity, radiation, } \\
\text { overpressure), the area over which } \\
\text { the effect is above a pre-defined } \\
\text { level of concern. }\end{array}$ & $\begin{array}{l}\text { For } \mathrm{NH}_{3} \text {, the area over which } \\
\text { the concentrations are } \\
\text { expected to be higher than a } \\
\text { specified threshold } \\
\text { concentration of the gas in } \\
\text { air. }\end{array}$ \\
\hline Consequence & $\begin{array}{l}\text { A measure of the expected negative } \\
\text { outcome from a given incident. }\end{array}$ & $\begin{array}{l}\text { A toxic release of ammonia, } \\
\text { for example, resulting in } \\
\text { death of } 40 \text { people and } \\
\text { injuries to } 60 \text { people. }\end{array}$ \\
\hline $\begin{array}{l}\text { Individual } \\
\text { Risk (IR) }\end{array}$ & $\begin{array}{l}\text { The frequency at which an individual } \\
\text { may be expected to sustain a given } \\
\text { level of harm from the realisation of } \\
\text { specific hazards. }\end{array}$ & $\begin{array}{l}\text { The risk of death to an } \\
\text { individual residing in a certain } \\
\text { area of interest being } 1 \text { in } \\
10,000 \text { in a year. }\end{array}$ \\
\hline $\begin{array}{l}\text { Societal Risk } \\
\text { (SR) }\end{array}$ & $\begin{array}{l}\text { The relationship between the } \\
\text { frequency and the number of people } \\
\text { suffering from a specified level of } \\
\text { harm in a given population from the } \\
\text { realisation of specific hazards. }\end{array}$ & $\begin{array}{l}\text { A probable loss of } 20 \text { lives / } \\
\text { year for the population in } 1 \\
\mathrm{~km}^{2} \text { of an area of interest. }\end{array}$ \\
\hline
\end{tabular}

References: (GoI:MoEF, 2000; IChemE, 1992; Lees, 1996) 
Several approaches exist for assessing risk originating from hazardous industries and they vary from purely quantitative to semi-quantitative and qualitative. Methods for Quantitative Risk Assessment (QRA) have evolved into an established practice to quantify a value of risk, based on the hazard potential of industries and the probability of damage to population present in the neighbourhood (Christou et al., 2011). Figure 2-1 depicts a standard QRA methodology for risk assessment and management, comprising of systematic steps to identify, analyse and evaluate risk from hazardous industrial facilities.

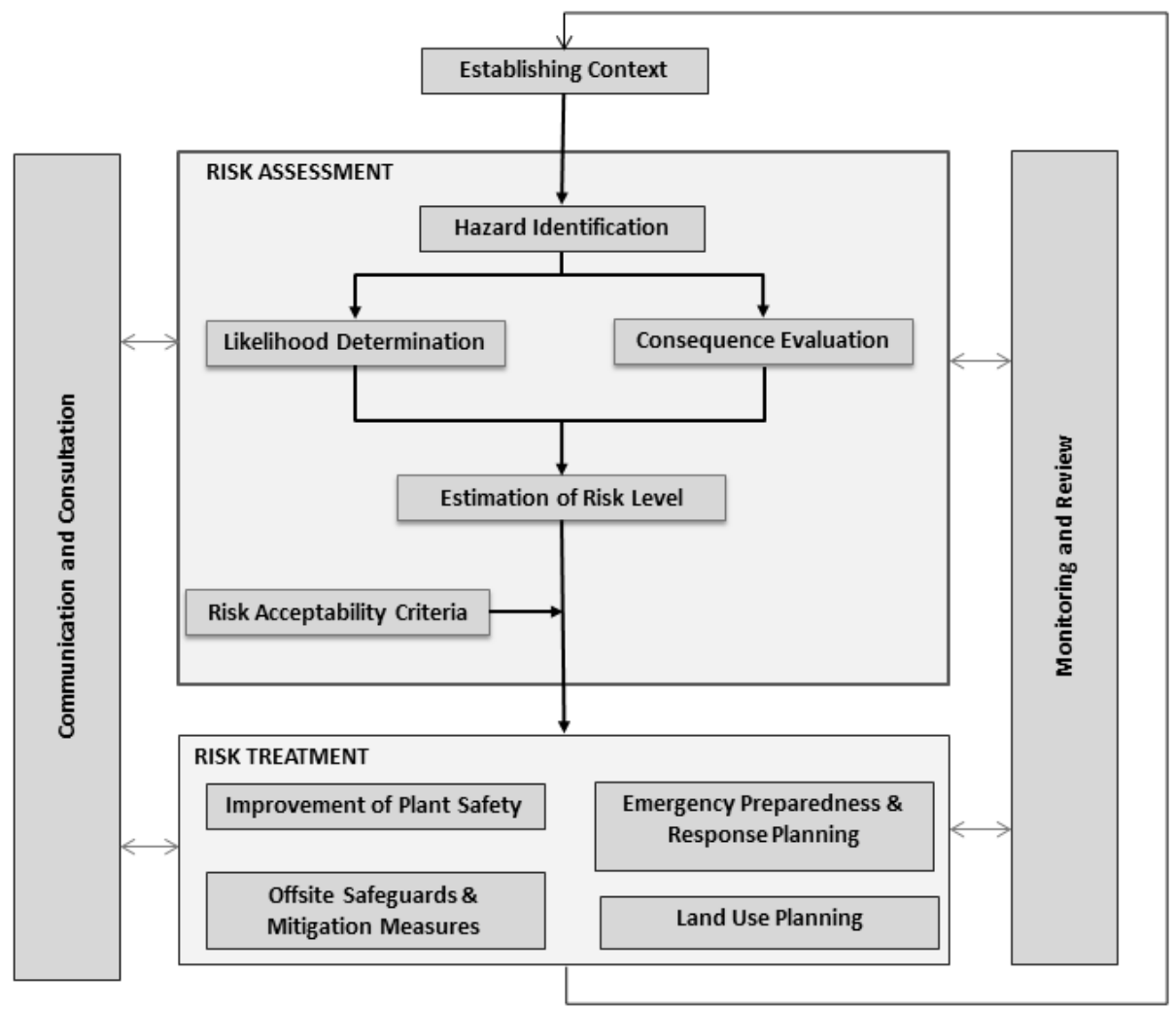

Figure 2-1: QRA Based Risk Assessment Methodology

The key steps in the methodology are as follows:

- Hazard Identification: This step involves attaining an understanding of the hazards, including the location, type of storage involved and the hazardous property of the chemicals. It also refers to the characterisation of the hazard or risk scenario associated with hazardous storage (Ale, 2002). Generally, a two-phase process is followed for identification of a hazard scenario. The relationship between the two is represented through a 'bow tie' model. First a 'fault tree' scenario leads up to the stage where 
a loss of containment can occur. Second, an 'event tree' considers the consequences of events following the loss of containment. Several methodologies have been formulated in earlier researches to specifically identify such accident scenarios (Delvosalle et al., 2005; Tugnoli et al., 2013).

- Likelihood Determination: Once the possible hazard scenario's and the type of negative outcome are identified, the scenario frequency is determined based on the failure frequency of the initiating event and the probability of intermediate events. The frequency of a scenario specifies the number of probable occurrences of that scenario in a period of time and are generally taken from failure frequency databases and literature prepared after analysing historical data of previous incidents (Uijt de Haag et al., 2005a). The probability of an intermediate event varies from $0-1$ indicating the possibility of occurrence of that event (Baesi et al., 2013).

- Consequence Evaluation: Consequence assessment involves determining the impact of an event in terms of physical extent and severity (Lees, 1996). The physical extent of an accident scenario usually involves calculating the maximum distances (i.e. effect distance) from the source at which people are negatively affected. The severity of an event is expressed as a level of harm to people, mostly in the form of a fatality or level of injury. The physical extent or effect of an accident scenario may vary widely based on a number of factors such as the type and amount of dangerous substance involved, nature of the storage, type and speed of the release and atmospheric conditions prevailing at the time of accident (Pe, 2005). Therefore, the calculation of an effect distance requires the use of accepted mathematical effect models to estimate the extent of damage that an accident scenario may cause. Generally, two types of models are used in QRA to estimate the effect of radiation, overpressure and toxic release on people. The first uses threshold limit values i.e. the value below which the damage is nil and above which the damage is total. The others use probit values i.e. mathematical value between the dose or the exposure and the fraction of people that might get killed (Ale, 2002; Fabbri et al., 2009).

- Estimation of Risk: Finally, the risk estimate is derived by multiplying the consequence of the event and the probability of occurrence. The risk is represented in the form of metrics like individual (IR) and societal risk (SR) (Jonkman et al., 2003).

The outcome of a QRA based risk assessment is often a risk map (Gheorghe et al., 2004). As both hazard and vulnerability have a strong spatial 
dimension, risk is mostly displayed in maps showing the distribution of risk which together with other risk related attributes form the basis for risk evaluation (Büchele et al., 2006; Carpignano et al., 2009; Lahr et al., 2010; Tyagunov et al., 2006). Presented through paper or electronic means, risk maps can play an important role in ensuring that the results of risk assessment are communicated to all actors involved in the risk assessment process or who in some way stand to get affected by risk related decision making (Basta et al., 2007; Moen et al., 1998). For industrial risk, the traditional method of risk mapping is based on quantitative techniques (Christou et al., 2011; Cozzani, Bandini, et al., 2006). This requires understanding of many aspects such as potential accident scenarios, probability of occurrences and possible impacts of fire, explosion or toxic releases. The computation of a risk metric like IR or SR can be visualized on a map of the concerned area, assisted by software tools (Spadoni et al., 2000; Uijt de Haag, 2013). In several developed countries, preparation of such risk maps for the major types of hazards (such as industrial hazards) are mandatory according to policy or regulatory frameworks. But at the same time, it must be noted that the QRA process becomes workable because of several inherent assumptions and simplifications of the scientific methods involved (Fabbri et al., 2009).

The last step in the risk management process for industrial hazards comprises of the risk treatment phase. Based on inputs from the risk assessment phase, this phase involves the selection and adoption of risk mitigation measures that aim to reduce residual risk to levels that are acceptable to society (Versluis et al., 2010). Key risk mitigation methods include improvement of plant safety, formulation of emergency preparedness and response plans, adoption of offsite safeguard measures and incorporating risk as a factor for land use planning in industrial areas. The selection of risk treatment or mitigation options usually involves the balancing of costs and efforts of implementation against perceived benefits with regard to protection of citizens and the environment.

It must be noted though that trends in decision making involving environmental and risk issues indicate a paradigm shift from technocratic approaches involving objective assessments undertaken by experts towards participatory frameworks (Eduljee, 2000; Renn, 2006). In 1996, based on a review of practice, the National Research Council of the United States proposed a shift from an earlier objectivity oriented approach. The authors of the report logically stress the necessity of making risk-related decision making an inclusive and participatory process and incorporating the perspectives and knowledge of interested and affected parties (Stern et al., 1996). This approach therefore articulates the requirement for integrating analytical reasoning with deliberation and interpretation, providing more 
opportunity for acceptance of risk decisions within a socio-political framework (Renn, 1999).

\subsubsection{Risk Decision Making - Emergency Preparedness and Response Planning}

The practice of industrial risk management deals with short-term strategies and plans that can help the administration and communities at risk to prepare for and respond effectively to major accidents originating from hazardous facilities. Effective management of emergencies requires careful planning, preparedness and response in order to be able to reduce damage, rescue victims, and ensure quick return to normalcy (FEMA, 1997). In the perspective of industrial risk, this would mean accidents like a toxic release, fire or explosion originating from a hazardous industry or a transportation accident involving a hazardous chemical. Emergency management deals with short-term preparedness and response strategies as well as long-term mitigation plans that can help the administration and communities deal with an emergency (Alexander, 2002).

Literature on emergency management identify four key phases:

- Mitigation: pre-disaster efforts directed at reducing the effect of a probable industrial event on human life and personal property;

- Preparedness: actions taken prior to a disaster event that enable disaster management units to appropriately respond to the hazard;

- Response: actions taken immediately prior to, during, and after, the accidental event that assists in reducing human and property losses as well as actions taken to aid in the post-disaster recovery effort;

- Recovery: actions and measures that facilitate the return of social and economic activities to an acceptable standard (Haddow et al., 2013).

The task of managing industrial emergencies is complex. Experience has shown that they often develop very rapidly, with factors that may change rapidly over time (e.g. weather conditions, traffic volumes, etc.). They are often difficult to predict and require multiple actors to work in coordination to arrive quickly at decisions to protect the community and the environment (Georgiadou et al., 2007; Sorensen et al., 2004). In addition, judgments during an emergency are often tentative, imprecise and approximate due to incomplete information and the inherent complexity and uncertainty of a rapidly evolving decision environment, where a mistake can lead to immensely adverse consequences on life and property (Levy et al., 2007). Such dynamic and time-sensitive requirements require emergency managers to efficiently use up-to-date information from several heterogeneous and multi-disciplinary sources in order to be able to make correct decisions. The decision-making requirements are most critical when an accident situation 
evolves, accompanied by uncertainty and rapidly changing information. A delay in reaching a decision may lead to higher loss of lives and/or damage to property.

\subsubsection{Risk Decision Making - Land Use Planning}

Significant damages caused by industrial accidents like Bhopal and Mexico City is related to inappropriate land use near highly hazardous facilities. In most of these cases, either the siting of an industrial facility was made without taking into consideration proximity to existing settlements or demographic pressure led to the migration of population around the hazardous industry later. This point to ineffective land use planning or regulatory restrictions leading to an increase of risk in industrial areas. Early studies done in the field of technological risk assessment in industrial areas have concluded with the requirement to formulate risk-based decision criteria for land use planning purpose (COVO, 1982). Consequently, judicious planning of land use around hazardous facilities or deciding on the siting of new hazardous facilities is internationally accepted to be an important risk reduction or mitigation measure and have been implemented through directives and legal instruments (EU, 2012; ISDR, 2004).

The International Strategy for Disaster Risk Reduction(ISDR) prioritises land use planning as a key instrument for disaster risk reduction in hazard prone human settlements, in particular for areas that are highly populated or are witnessing fast urbanisation (ISDR, 2005). As a part of such focus, the ISDR encourages the development of methods and tools to guide risk reduction strategies and risk sensitive spatial planning. Many countries have developed directives and legal instruments that take into account risk acceptability criteria in spatial planning, for the management of industrial risks from hazardous installations and transportation of hazardous substances. In continental Europe, where hazardous installations are often located in areas having high population densities, the Seveso II Directive requires that the consequences of industrial accidents be taken into account. This is done through appropriate land use policies and controls when dealing with the planning of new industrial facilities, undertaking modifications to land use around existing ones and new residential developments in the vicinity of hazardous establishments (Porter et al., 1999; Versluis et al., 2010).

While creating sufficient separation distance between such facilities and residential areas can provide for a straightforward solution to the problem, such decisions are often difficult to implement in areas having high population densities and where use of land is constrained. As a result, decisions related to location of new hazardous facilities or related to the planning of new residential areas in industrial areas often tend to have conflicting objectives. On one side, land use planners have to account for the 
safety of surrounding population in an industrial area while on the other they have to consider options to exploit land in the best possible manner. This requires accounting for socio-economic considerations like employment opportunities, benefits to local community from operation of an industry and objectives for area-level industrial development. Related to such divergent objectives different stakeholders including industry, administration, employees, communities and interest groups bring in different priorities and values which need to be considered in the decision making process (Christou et al., 2000).

The implementation of the Seveso Directive, which provides regulatory guidance on risk-based land use planning, amongst European Member States varies considerably depending on the perception of the prevailing safety situation, country level regulatory approach towards risk assessment and the available methods and tools available for tackling the problem (Pasman et al., 2014). A review of such country level procedures and practices show also considerable diversity in terms of methods for identification of risk scenarios, probability of failures leading to accidents, consequence models used for risk calculation and criteria for risk acceptability (Christou et al., 2011). The assessment of risk from hazardous installations in the Netherlands is guided by the External Safety Policy and traces its origins to the 1970's when the Rijnmond risk assessment study was commissioned to formulate safety goals and then relate them with land use planning guidelines (BRZO, 1999; COVO, 1982). The Dutch risk assessment practice is hinged on the use of QRA methods to determine risk, which is then compared to criteria's for IR and $\mathrm{SR}$. The QRA process requires the adoption of a standard process as stipulated in the BEVI Manual for RA resulting in the estimation of a numerical value for risk (Uijt de Haag, 2013). For populated areas, the Dutch Ministry of Housing, Spatial planning and Environment (VROM) has set the standard IR $<10^{-6}$ (per year) and the spatial disposition of IR is generally represented with individual leading iso-risk contours overlaid on a geographic map of the establishment and its vicinity (Bottelberghs, 2000). In addition, the SR criteria is also taken into account in order to plan for any new development in an area, where risk sources are present. It is represented through a societal risk $(F, N)$ plot showing cumulative complementary frequency distribution where the absolute probability $\mathrm{F}$ for an accident with more than $\mathrm{N}$ lethal victims is plotted against group size $\mathrm{N}$ (Ale, 2002; Bottelberghs, 2000). The risk measures are illustrated in Figure 2-2. 

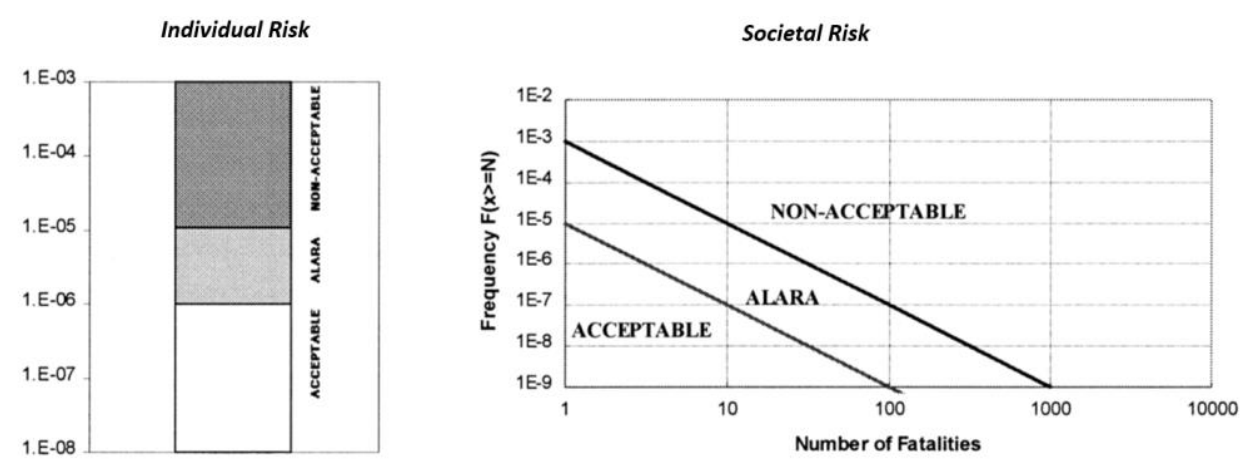

Figure 2-2: Risk measures in the Netherlands

Source: (Christou et al., 2011)

United Kingdom's (UK) approach to risk assessment of hazardous facilities is quite similar to the Dutch system and is influenced by studies done in 1978 for the proposed extension of chemical processing of an industrial site in Canvey islands. The UK Health and Safety Executive (HSE) provides appropriate health and safety advice for land-use planning in order to mitigate the effects of a major accident on the population in the vicinity of hazardous installations. This is in accordance with a consistent and systematic approach for risk analysis laid down in the Control of Major Accident Hazards involving Dangerous Substances (COMAH) regulation and the corresponding planning advice for developments near hazardous installations, in short PADHI (HSE, 1999, 2011). The advice is implemented through the regulation of planning permissions provided by the local planning authority.

Several other European nations have adopted approaches that range anywhere between strictly qualitative to quantitative (Christou et al., 2011). Germany has adopted a deterministic approach wherein the land-use planning criteria for locating hazardous industry are decided based on safety distances that separate areas of different use. The safety distances are specified after hazard assessment for each type of installation based on a consequence-oriented approach that takes into account the maximum credible amount of a hazardous substance getting involved in an accident. Local authorities are responsible for preparing land-use plans taking into account such safety distances and restrict the use of land within such areas (SFK/TAA, 2011). Typical approaches to risk-guided land use planning followed in other countries like the Industrial risks prevention plans in France and the Technical Document on Risk, called Rischio di Incidente Rilevante (which stands for major risk accident) is discussed extensively in literature (Cahen, 2006; Demichela et al.). Risk assessment approaches and guidelines for hazardous facilities have been laid down in many countries and QRA based practices are sufficiently well established amongst the scientific risk 
community (Lees, 1996). However, several aspects like the availability of dependable data, identification of accident scenarios, risk calculation models and risk acceptance criteria continue to be researched and debated in many countries of the world (Fabbri et al., 2009; Salvi et al., 2006).

\subsubsection{Risk Communication}

A related but equally important front in risk governance concerns the availability of risk information, communication between concerned parties and awareness amongst stakeholders. Risk governance emphasizes the importance of effectively exchanging risk information in order to enable stakeholders and civil society to understand the results from the risk assessment process and the justifications for decisions taken based on this information, guiding them to make informed choices about risk (Renn, 1999). The IRGC risk governance model also considers risk information and communication as a central element of integrated framework for risk management (IRGC, 2005).

General principles formulated through international and regional conventions have recognised that citizens have a right to know about existing environmental and risk related hazards in their neighbourhood, express their concerns and be party to decision making in order to enhance the quality and implementability of such decisions (UNCED, 1992; UNECE, 1998). The Hyogo Framework for Action 2005-2015 stressed on the use of knowledge, innovation and education in order to build a culture of safety and resilience from risk at all levels of governance. An important cornerstone of this strategy is the provision of information on disaster risks through the strengthening of information networks and dialogue amongst risk experts, managers and planners (ISDR, 2005). The strategy laid considerable emphasis on the development of national information sharing systems to capture relevant knowledge on disaster risk reduction and dissemination to risk actors and citizens. This has recently been carried forward through the Sendai Framework for Disaster Risk Reduction 2015 - 2030 (UN, 2015).

The success of regulatory approaches for industrial risk management depends to a considerable extent on the availability of up-to-date and valid information on hazards, dangerous substances, and vulnerabilities existing in the surroundings of hazardous installations. International agreements like the Aarhus Convention oblige public authorities to allow public access to environmental information and provide opportunities for participation in the decision making process (UNECE, 1998). In Europe, the Seveso Directive $(82 / 501 / E C \& 88 / 610 / E C)$ stresses the exchange of information between governments, industry and the public and requires Member States to actively inform the public likely to be affected by potential industrial accidents about the nature of the risk and the best way to act in the event of an accident (EU, 
2012). However, there is also a strong debate on how much, what hazard and risk information should be shared with the public, and the level of acceptance to share such information varies with the regulatory requirements that prevail in individual countries (Wynne et al., 1991 154).

Initially, the risk communication mandate for hazardous industries revolved around the view of 'need to know' where information could be passively conveyed to the community on aspects like emergency action. However, with an evolving paradigm for a more active communication of risk information, the communities have increasingly voiced support for a 'right to know' about sources of hazards and prevailing risk as also participation in risk related decision making. This led to the strengthening of public information provision in many regulations proposing adoption of active methods for supply of information and led to the evolution of a broader relationship between government, industry and the public for handling risk problems (Walker et al., 2000). The public is increasingly not ready to accept the legitimacy of decisions involving environmental or hazard related issues, particularly those pertaining to regulatory decision making that depend on scientific evidence to underpin or justify such decisions. There is an increasing interest in deliberative approaches to environmental risk related issues that seek to encourage the involvement of stakeholders in the public decision making process at the local level (Owens, 2000; Spash, 2001). Consequently, the need for proactively sharing of information related to hazards is also becoming the norm as compared to the reactive stance that was maintained by hazardous industries previously, citing concerns of security or of alarming the neighbouring community (Gouldson, 2004). It is expected that with time, the adoption of such approaches will lead to the emergence of new governance paradigms, which would be more inclusive i.e. involve transparent sharing of information and participation for decision-making.

\subsection{Risk Information, Decision and Planning Support Systems - A Review}

\subsubsection{Progress of Decision \& Planning Support Systems - Recent Developments}

Terminologies related to ICT based tools that assists in solving complex problems and decision-making has been a key topic of research in the last few decades. Power (Power, 2008) traced back the historical roots for such ICT based tools to the early 1970's. Gorry et al. (1971) postulated the term "Decision Support System (DSS)" for computerized systems that could provide additional functionalities to that of traditional management information systems and provide assistance in the areas of modelling and analysis for unstructured or semi-structured problems. Since then, there has 
been scores of terminologies and common denominators around which scientific communities gathered for naming such systems. Recent and evolving terminologies that characterize such systems range from "decision support system infrastructure" to "collaborative planning support systems". In principle, most of these systems attempt to cover any or several of the activities involved in a logical decision-making or planning process. Such a process can be generalized in three key steps as: (a) setting a goal and gathering of intelligence for attempting a solution to a problem; (b) design of alternative strategies, plans or options for solving the problem; (c) evaluating alternatives alternative solutions and making a 'choice' (McIntosh et al., 2011). In order to keep this discussion relevant, we focus on three specific categories of decision support tools in this section, which are important from the point of view of this research, their definitions and other specific aspects related to their evolution and use.

Information-Driven DSS: Information driven DSSs are primarily information systems that work on a body of data and knowledge related to a domain or a specific problem set, providing analysis, answering specific queries and providing mechanisms for sharing relevant information that can guide decision-making and planning. According to some researchers, at a preliminary level, any website containing relevant information (the Wikipedia for example) can be considered in some ways to support decision making by providing textual information, static tables and graphics. However, information based DSSs are expected to have significant amount of problem specific data which are stored in databases and available for querying and numerical or statistical analysis. Web-GIS portals can be considered to be a significant offshoot of information-based DSS and a preferred solution space for finding solutions to spatial problems. An exponential growth in technology, bandwidth and availability of computing capability in devises like cell phones has in turn significantly influenced the application of GIS for finding solutions to spatial problems, allowing for querying and analysis of spatial information and providing customized interfaces for map-based visualization. The widening and expansion of technology base has also provided the scope for converging of several technologies closely related to GIS such as Global Positioning System (GPS), remote sensing, wireless communications and the internet (Drummond, 2008; Merali et al., 2012). The evolving web-services architecture is decentralized in that the spatial analysis function resides on a central server and the user can access the solution through a thin-client web browser interface via an online computer (Peng et al., 2003).

Data warehouses and spatial data libraries have come into existence and several standards and common protocols for data exchange have been established to ensure interoperability between data and systems operating 
over the distributed architecture of the internet (OGC, 2003). Considerable progress has been made on the vision of Digital Earth which was articulated as a multi-resolution, three-dimensional representation of the planet that would make it possible to find, visualize and make sense of vast amounts of geo-referenced information on physical and social environments (Gore, 1999). Geo-browsers like Google Earth and Bing provide innovative ways of organising and presenting geo-data through the internet (Craglia et al., 2011; Goodchild et al., 2012; Goodchild, 2008). Web 2.0-based GIS services now provide for bi-directional collaboration through which users are able to interact with online maps and provide information to central sites thereby building on the principle and providing scope for effective public participation (Goodchild, 2011). Recent visions of web-based map services have coined the Web 3.0 terminology which is meant to be an integration of the Semantic Web (web of meaning) technologies with the principles of Web 2.0 (the web of people) (Wahlster et al., 2006). Current research in this direction involves further attempts to develop dynamic information flows of social and environmental interactions, exploiting developments in web-enabled sensors and opportunities to integrate information generated by social networks and citizens (Annoni et al., 2011). Web 3.0 or the Semantic Web is increasingly focusing on finding meaning in data through the use of ontologies, mark-up and databases utilising semantic geospatial web services (Zhao et al., 2010).

With the proliferation of geographic information in the early 1990's, a need was felt by national governments to develop a common information system infrastructure that would allow for a standardized approach towards the preparation and access of geographical information (Groot et al., 2000; Williamson et al., 2003). The term Spatial Data Infrastructure (SDI) was coined by the US National Research Council as a platform to assemble geographic information on features and attributes on Earth and utilising materials, technology, and people necessary to acquire, process, store and distribute such information (NRC, 1993). SDIs are often claimed to support decision-making and planning. According to Rajabifard et al. (2002), SDIs would help to achieve better outcomes for economic, social and environmental decision making thereby allowing government activities to be more transparent and can increase public participation in the democratic processes. According to the UNSDI (2008), the SDI can facilitate decision making by enabling access, retrieval, dissemination and use of geospatial data.

Current SDIs under development are increasingly looking forward to achieve higher level of syntactic and structural interoperability (through common metadata formats and structural schemas), wherein the service offered by a particular SDI can be consumed by other web services, applications or clients across platforms over distributed net environment (Zhao et al., 2010). The 
OGC standard specifications like Web Map Service (WMS), Web Feature Service (WFS) allow for managing of geographic information enabling access and presenting spatial data from multiple sources through a SDI geo-portal. The 'geo-portal' normally is a website that acts as an entry point to a SDI and helps in finding contextual geographic content on the web (Maguire et al., 2005). Conceptualisation of new systems that are capable of using such shared data and infrastructure to support decision-making are being referred to by new terminologies like 'spatial decision/planning support infrastructure (Boerboom, 2010).

Spatial Decision Support Systems: Though GIS technologies are capable of providing support to decision making and planning, with capability for handling consolidating geo-referenced data, tools to analyse and manipulate the data and visualization interfaces, GIS still remains a general purpose tool applicable to a wide range of tasks and problem sets (Longley et al., 2005). Spatial Decision Support Systems (SDSS) evolved as a subset of DSSs in the mid-1980s and designed with the objective of providing the decision maker with context specific framework for integration of spatial analysis, models, database management systems (DBMS), graphical display, tabular reporting, and the expert knowledge of the decision-maker (Armstrong et al., 1986; Carver, 1991). Therefore, in addition to the common characteristics of DSS, an SDSS is expected to incorporate additional capabilities in terms of being able to store and process spatial geo-referenced data, allow for representation of spatial relations, provide scope for spatial analysis and show the outputs in a spatial form, preferably using a map (Densham, 1991). Since the early 1990's, researchers have conceptualised, designed, developed and evaluated a range of SDSS's to cater to different complex problem sets. They include integration of simulation models and expert systems (Fedra et al., 2002), optimisation (Georgiadou et al., 2010), multi-criteria analysis (Malczewski, 2004), group decision-making (Jelokhani-Niaraki et al., 2012), visual-analytical data exploration (Andrienko et al., 2007).

Building on the success of web-GIS, there has been increasing interest of using the power and flexibility offered by the distributed web architecture to deliver spatial decision support to the user, hiding the complexity of decision models and algorithms while making it more accessible to planners and decision makers (Bhargava et al., 2007; Shim et al., 2002; Sugumaran et al., 2007). Web enabled decision support and related computations can be designed in various ways. But, in keeping with basic design principles, often most of the data, decision models and algorithms required to support decision making resides in distributed web-servers and the two-way communication between these tools and the user can be delivered through an interactive thin client interface (Zhang et al., 2007). Research in practice show that such decision and planning support systems have a better chance 
of being compared favourably with respect to desktop systems, as they are more accessible, user friendly and less cumbersome and resource intensive (Balram et al., 2009).

New SDSS frameworks are taking advantage of distributed online databases, common standards (OGC) for exchange and sharing of information, availability of models as a service (MAAS), common templates for visualization of spatial data using web based tools like Google Earth (Craglia et al., 2011; Goodchild et al., 2012; OGC, 2003; Roman et al., 2009). In addition, newer specifications like the Geo-Decision Support Services (GeoDSS) are being developed which will allow users to collaborate utilizing workflow management and engage geospatial web services in multiple domains to enable interoperable decision support environment. Using specifications like GeoDSS, it would be possible for example to explore service chaining of modelling tools with Sensor Web data, along with OGC based web services to provide real time decision support (OGC, 2007).

Planning Support Systems: Planning Support Systems (PSS), a term first coined by Harris (1989), made its entry into the planning scene as a concept that intends to present planners with a computerised 'toolbox' enabling a specific planning task - the underlying concept is based on an approach called 'sketch planning' discussed since the 1960s. In 1999, Klosterman (1999) defined a PSS in more specific terms as an integrated information system which couples GIS data, operational models and advanced geo-visualization tools to support core planning functions. From the terminology point of view, it is also pertinent here to clarify what principally makes a PSS distinctive from a SDSS. A PSS has several aspects in common with SDSS - both of them aim to solve ill or semi-structured decision problems and in doing so, utilise computer-based components like databases, models and visualization interfaces. However, whereas a SDSS focuses more on operational decisionmaking, a PSS generally pays particular attention to long term problems of a strategic nature and generally involves a group decision perspective (Geertman et al., 2004). As the field of PSS further evolved, the definition has been extended further. Geertman and Stillwell (2009) made a more recent conception of PSS which focuses on issues such as planning theory and methods, reinforcing the relationships between the planning process and the enabling technology as an integrated computer based framework. This new integrated framework for PSS is a combination of three key components:

- a planning task at hand with established methods;

- a combination of appropriate data, knowledge base and models that are capable of informing the planning process through analysis, prediction and prescription; and 
- the transformation of basic data into information through appropriate visualization and display.

In the present perspective, traditional off-the-shelf tools that dominated computer-aided planning discussions in areas such as urban land use and transportation no longer form the core of PSS. The key reasons for this were: the highly variable data requirements, lack of adequate coupling with GIS, limited visualization capabilities and platforms restricted to desktops thereby providing limited potential for communicating scenario results to a wider group of stakeholders (Batty, 2007). Recent literature discusses efforts to integrate PSSs into the open, active and interactive decision making environment offered by world wide web (Boroushaki et al., 2010b; Dragicevic, 2008; Jankowski, 2009). For example, the earlier desktop Whatif? which served as a key example of an operational PSS (Klosterman, 1999) is being converted into an Online What-if? PSS as a part of the Australian Urban Research Infrastructure Network (AURIN) project. The solution would provide the functionality online to prepare conditional scenarios for an area's future land use, population and employment patterns (Pettit et al., 2013). Jelokhani et al. (2012) presents the concept of a web 3.0 driven system for solving parking problems in the city of Teheran. Recent advances in PSSs also focus on improved visualization, communicating and disseminating essential guidance in an interactive manner and user-friendly form to planners and other constituencies, while coupling analytical tools and computer simulation models at the back end, all through the web (Batty, 2007).

Going forward, several researchers have predicted that PSSs would increasingly facilitate group understanding through collaborative planning processes in additional to providing assistance to data management, analytical problem solving, decision-making and communication. A review of current planning support systems indicates that the majority happen to be online systems and with several tending to provide collaborative platforms for use by multiple stakeholders (Campagna et al., 2012; Geertman et al., 2009). Such new generation PSSs are expected to change the way planning decisions are made on complex problems in two significant ways. First, the use of distributed PSS could shift the focus of planning from the regulatory style that prevailed earlier to a more proactive performance oriented approach. Second, by providing scope for public involvement in the planning process, build a consensual approach to arriving at such decisions, which involves conflicting views and opinions. Recent developments indicate that online collaborative PSSs, which can facilitate group understanding utilising online participative planning processes, are increasingly gaining currency amongst the planning community (Pettit et al., 2013). Developers of PSS have also realised that with high levels of penetration of the internet in 
society, web based methods have the potential to reach large numbers of interested stakeholders, if required anonymously, and obtain their support using communicative planning processes. Such new approaches are increasingly leading to the democratising of planning process by taking advantage of the online platform. However, there have been few implementations that provide a viable alternative to traditional methods of obtaining stakeholder opinions for spatial planning, through a web-enabled spatial multi-criteria oriented tool that is supportive of the deliberative dimension of decision making i.e. not restrict collaboration by time or location of participants (Boroushaki et al., 2010a; Rinner et al., 2009).

\subsubsection{Present Applications of DSS \& PSS in the Domain of Risk Management}

Management of industrial risk involves considerable complexity from the point of view of a decision-maker and planner. It requires information from multidisciplinary sources, understanding of principles involving hazard and risk estimation, the use of scientific rationality for treating decision problems and evaluating alternatives. In line with the industrial risk management framework that was discussed in the earlier section, we consider three areas where applications of decision and planning support systems would be relevant.

SDI focusing on Industrial Risk: Given the multidisciplinary nature of disaster and risk information requirements and the need for relevant, reliable and accurate information, an information system infrastructure which allows for efficient sharing and consolidation of data from several heterogeneous sources is a vital requirement (Neuvel et al., 2010). With a strong spatial bearing involved in risk management problems, it is expected that considerable amount of such information will have spatial data components. Therefore, the use of geo-information sciences and a common infrastructure for collecting, storing, analysing and presenting geo-spatial data is considered necessary for the effective management of industrial risk and disasters (Cova, 1999; MacFarlane, 2005; Mansourian et al., 2006; NRC, 2007; SNDR, 2002; Zlatanova et al., 2009). The UN recognises the need for a major effort to generate appropriate data, and consolidate them into information and knowledge to support risk based decision-making and planning (UN, 2007).

Emergency Decision Support: Industrial emergency management deals with complex and dynamic situations, having uncertainties, often in a rapidly changing decision environment. It is also recognised that emergency management, especially the response phase, is highly information intensive and requires multiple organisations to share information, expertise and resources in undertaking rapid situation assessment and decision-making. 
This may be in the form of quantitative estimates from modelling, integrated analysis coupled with formalized assessment criteria, or accounting for stakeholder preferences and alternatives to arrive at decision choices (Linkov et al., 2005; Matthies et al., 2007; McIntosh et al., 2011). Because of these challenges, emergency decision support is a favourite domain of application for DSS researchers (Cova, 1999; MacFarlane, 2005; Radke et al., 2000; SNDR, 2002; Zlatanova et al., 2009). These researches focus on the question of how to provide informational and decision support to emergency planners and responders, through different phases of the emergency management process.

Planning Support Applications: The calculation of a risk measure for an area where multiple hazard sources are present is a basic requirement in order to guide risk reduction plans. Risk estimation needs to take into account many possible accident scenarios, requiring processing of large amounts of data, running of impact assessment models and undertake a summation of overall risk (Ale, 2002; Basta et al., 2007; Moen et al., 1998; Pietersen et al., 1992). Quantitative methods involved in such estimation are often computationally intensive and needs choices to be made on several alternatives in a decision tree to arrive at rationale conclusions. Qualitative methods require agreement on indicators and devising methods for combining them into a normative risk index (Greiving et al., 2012).

Table 2-2 represents the characteristics of a range of information systems, which are pertinent to different aspects of risk management decisions. As applications for industrial risk management are not many for some domains, we also include examples from natural risk and disaster management. In addition, not all the tools can be considered to be full-service DSS or PSS, but play a role in supporting decision making in at least one of the phases of the decision-making process. 
Table 2-2: Review of Existing Information, Decision \& Planning Support Systems for Risk Management

\begin{tabular}{|c|c|c|}
\hline $\begin{array}{l}\text { Authors } \\
\text { (Year) / } \\
\text { Source }\end{array}$ & $\begin{array}{l}\text { Name of Tool and } \\
\text { Methods }\end{array}$ & $\begin{array}{l}\text { Research Purpose \& Decision Aiding } \\
\text { Technique }\end{array}$ \\
\hline \multicolumn{3}{|c|}{ Risk Information Systems } \\
\hline https://www & Google Maps integrated & Information based DSS providing up-to-date \\
\hline google.co.in & $\begin{array}{l}\text { with Models from other } \\
\text { sources. }\end{array}$ & spatial information on hazards \\
\hline $\begin{array}{l}\text { UNISDR } \\
\text { http://risk.p } \\
\text { reventionwe }\end{array}$ & $\begin{array}{l}\text { Risk Data Platform as a } \\
\text { module of the CAPRA } \\
\text { (Comprehensive Approach }\end{array}$ & $\begin{array}{l}\text { Portal for sharing spatial data and information on } \\
\text { global natural hazards/risks. The tool allows for } \\
\text { visualization, downloading or extraction of data on }\end{array}$ \\
\hline b.net & $\begin{array}{l}\text { to Probabilistic Risk } \\
\text { Assessment) }\end{array}$ & $\begin{array}{l}\text { past hazardous events, human \& economical } \\
\text { hazard exposure and risk from natural hazards. }\end{array}$ \\
\hline $\begin{array}{l}\text { FEMA } \\
\text { http://riskm } \\
\text { approgress. } \\
\text { msc.fema.go } \\
\text { v/ }\end{array}$ & $\begin{array}{l}\text { Risk Mapping, Assessment } \\
\text { and Planning (Risk MAP) } \\
\text { program }\end{array}$ & $\begin{array}{l}\text { Portal provides high quality online flood maps and } \\
\text { information, tools to better assess the risk from } \\
\text { flooding and planning and outreach support to } \\
\text { communities to help them take action to reduce } \\
\text { (or mitigate) flood risk. }\end{array}$ \\
\hline $\begin{array}{l}\text { http://cedim } \\
\text { gfz- } \\
\text { potsdam.de/ } \\
\text { riskexplorer/ } \\
\text { (K"ohler et } \\
\text { al., 2006) }\end{array}$ & CEDIM Risk Explorer & $\begin{array}{l}\text { The Risk Explorer allows the user to retrieve maps } \\
\text { of datasets developed within the project CEDIM } \\
\text { risk map for Germany including natural and man- } \\
\text { made hazards, vulnerability and risk as well as } \\
\text { assets (elements at risk). }\end{array}$ \\
\hline $\begin{array}{l}\text { Association } \\
\text { of Provinces } \\
\text { (IPO) } \\
\text { http://www. } \\
\text { risicokaart.nl } \\
\text { Len/ }\end{array}$ & Risicokaart (Risk Map) & $\begin{array}{l}\text { The risk map provides the most up-to-date and } \\
\text { complete picture of the risks in the Netherlands for } \\
\text { several hazards: industrial, nuclear, aviation, } \\
\text { traffic, fire, etc. }\end{array}$ \\
\hline $\begin{array}{l}\text { (Annoni et } \\
\text { al., 2005) }\end{array}$ & $\begin{array}{l}\text { ORCHESTRA as } \\
\text { component of INSPIRE }\end{array}$ & $\begin{array}{l}\text { Project planned to link spatial and non-spatial } \\
\text { information services and help in deploying service } \\
\text { infrastructure to serve risk management needs } \\
\text { and tied up to the INSPIRE SDI in Europe. }\end{array}$ \\
\hline \multicolumn{3}{|c|}{ Emergency DSS } \\
\hline $\begin{array}{l}\text { (Zografos et } \\
\text { al., 2000) }\end{array}$ & $\begin{array}{lr}\text { DSS for } & \text { Hazardous } \\
\text { Materials } & \text { Emergency } \\
\text { Response Operation }\end{array}$ & $\begin{array}{l}\text { Presents a methodological framework for } \\
\text { developing an unified framework for emergency } \\
\text { response involving hazardous materials, taking } \\
\text { into account multiple stakeholders, fragmentation } \\
\text { of responsibilities, dynamic real time decisions and } \\
\text { lack of formal management structure for } \\
\text { monitoring and control. }\end{array}$ \\
\hline $\begin{array}{l}\text { (Karagiannis } \\
\text { et al., 2010) }\end{array}$ & $\begin{array}{l}\text { Industrial emergency } \\
\text { planning modelling }\end{array}$ & $\begin{array}{l}\text { Proposes a methodology for DSS that can } \\
\text { iteratively model industrial emergency plans to } \\
\text { check robustness and identify failures. }\end{array}$ \\
\hline $\begin{array}{l}\text { (Vescoukis } \\
\text { et al., 2012) }\end{array}$ & $\begin{array}{l}\text { SoA for } \begin{array}{l}\text { DSS } \\
\text { environmental } \\
\text { management }\end{array} \\
\text { crisis }\end{array}$ & $\begin{array}{l}\text { Proposes an architectural framework that goes } \\
\text { beyond integration and presentation of static } \\
\text { spatial data, to include real time middleware } \\
\text { responsible for selecting the most appropriate } \\
\text { method of the available geospatial content and } \\
\text { service in order to satisfy the requirements of } \\
\text { users. }\end{array}$ \\
\hline $\begin{array}{l}\text { (Turoff et } \\
\text { al., 2004) }\end{array}$ & $\begin{array}{lr}\text { Dynamic } & \text { Emergency } \\
\text { Response } & \text { Management } \\
\text { Information } & \text { System } \\
\text { (DERMIS) } & \end{array}$ & $\begin{array}{l}\text { A tool designed to directly support responders in a } \\
\text { local crisis-situation, assisting in developing a } \\
\text { coordination structure among all the involved } \\
\text { parties and agencies and implemented in the US. }\end{array}$ \\
\hline $\begin{array}{l}\text { (De Maio et } \\
\text { al., 2011) }\end{array}$ & $\begin{array}{l}\text { Framework for } \begin{array}{r}\text { a } \\
\text { knowledge }\end{array} \text { based } \\
\text { approach for Emergency } \\
\text { Management }\end{array}$ & $\begin{array}{l}\text { Use of semantic web technologies and Fuzzy } \\
\text { Cognitive Maps to handle uncertainties during an } \\
\text { emergency situation by providing a shared and } \\
\text { harmonised vision to all actors involved in an } \\
\text { emergency situation including the availability of } \\
\text { resources like hospitals, ambulances and } \\
\text { volunteers. }\end{array}$ \\
\hline
\end{tabular}




\begin{tabular}{|c|c|c|}
\hline $\begin{array}{l}\text { (Bortenschla } \\
\text { ger et al., } \\
2007 ; \\
\text { Neuvel et } \\
\text { al., 2010) } \\
\text { http://www. } \\
\text { geodan.com } \\
\text { Lproducts/ea } \\
\text { gle- } \\
\text { cms/\#t intr } \\
\text { oduction tab }\end{array}$ & $\begin{array}{l}\text { EAGLE - Net-centric Crisis } \\
\text { Management System }\end{array}$ & $\begin{array}{l}\text { An integrated crisis management system that aims } \\
\text { to manage an incident or crisis as quickly as } \\
\text { possible by linking (geo-) information sources in } \\
\text { order to perform fast and accurate assessments } \\
\text { for the purpose of operational use and decision- } \\
\text { making. }\end{array}$ \\
\hline \multicolumn{3}{|c|}{ PSS for Risk Mitigation } \\
\hline $\begin{array}{l}\text { (Van Het } \\
\text { Veld et al., } \\
\text { 2007) }\end{array}$ & RISKCURVES \& EFFECTS & $\begin{array}{l}\text { Designed on models and calculations proposed in } \\
\text { the Yellow Book, a consequence modelling toolset } \\
\text { called EFFECTS with the QRA based risk } \\
\text { summation being provided through RISKCURVES }\end{array}$ \\
\hline $\begin{array}{l}\text { (Technica_Lt } \\
\text { d., 1985) }\end{array}$ & PHAST \& SAFETI & $\begin{array}{l}\text { Hazard analysis and QRA tool. In addition to } \\
\text { estimating risk metrics, provides decision support } \\
\text { for strategic planning, facility siting and layout. }\end{array}$ \\
\hline $\begin{array}{l}\text { (Binda et } \\
\text { al., 2009; } \\
\text { Spadoni et } \\
\text { al., 2000) }\end{array}$ & ARIPAR & $\begin{array}{l}\text { A QRA based risk assessment tool used to } \\
\text { evaluate risk resulting from major accidents in } \\
\text { hazardous industries and integrated with ArcGIS. }\end{array}$ \\
\hline $\begin{array}{l}\text { (Chen et al., } \\
\text { 2001) }\end{array}$ & MCE-RISK & $\begin{array}{l}\text { Tool integrating GIS and MCE for supporting } \\
\text { decisions on natural hazard management. }\end{array}$ \\
\hline $\begin{array}{l}\text { (Yatsalo et } \\
\text { al., 2010) }\end{array}$ & $\begin{array}{l}\text { Decision Evaluation for } \\
\text { Complex Environmental }\end{array}$ & $\begin{array}{l}\text { MCE based methodology and software tool to } \\
\text { support risk based land use planning decisions for }\end{array}$ \\
\hline & $\begin{array}{l}\text { Risk Network Systems } \\
\text { DECERNS }\end{array}$ & contaminated sites. \\
\hline $\begin{array}{l}\text { (Papazoglou } \\
\text { et al., 2000) }\end{array}$ & & $\begin{array}{l}\text { Methodological approach based on the theory of } \\
\text { MCDA to support the choice of land use patterns in } \\
\text { the vicinity of major hazard facilities. }\end{array}$ \\
\hline $\begin{array}{l}\text { (Grønberg, } \\
1999)\end{array}$ & LUPACS & $\begin{array}{l}\text { Methodology for supporting a user in structuring } \\
\text { land-use situation through the development and } \\
\text { comparison of alternative courses of action to } \\
\text { factor in community goals of acceptable risk. }\end{array}$ \\
\hline
\end{tabular}

\subsubsection{Use \& Effectiveness of Decision \& Planning Support Tools}

Despite the fact that the first decision and planning support tools emerged more than thirty years back, the application of DSS and PSS's have been limited mostly to the scientific community, with diffusion amongst professionals and practitioners being quite limited (Campagna et al., 2012). Problems with DSSs have been attributed to the lack of interoperability between datasets maintained by different organizations, lack of an appropriate platform for data exchange, insufficient standardization and protocols required to data sharing, and inappropriate quality of information to assist in decision making (Mansourian et al., 2006; Radke et al., 2000; Zerger et al., 2003). The WTC Attack of 2001 provided significant learning with regard to the challenges faced by computer-based systems and how GIS data generated by different departments needed to be flexibly used in supporting real-life extreme event decision making (Kevany, 2003; Mendonça, 2007). Similarly, difficulties have been encountered in accessing disaster related data from several government departments, as they lacked a common policy, equipment, software and human resources to be able to share information when required (Molina et al., 2011). Although many of 
these tools promise to provide vital decision support, simulation exercises involving utilization of spatial decision support tools have also highlighted several deficiencies (Erden et al., 2007; Kevany, 2003; Uran et al., 2003; Zerger et al., 2003).

In context of PSS, Geertman et al. (2004) identified two key reasons for this rather slow uptake into planning practice. First, system developers often do not sufficiently appreciate the user's perspective in terms of planning context and nature of the problem, the training of the staff and the resources available for deployment of such systems. Second, planning practitioners need to receive adequate training so that they find the newly developed tools to be acceptable. In a SWOT analysis of popular planning support systems, Vonk (2007) discussed three key weaknesses in an assessment involving several PSS's which led to lack of use amongst potential users:

- the gap between lower level demands of planners for simple information outputs compared to the complex analysis and exploration function provided by most PSSs;

- limitation in conveying convincing results efficiently through proper visualization to people having the power to make decisions;

- the lack of participatory frameworks for use of PSS by professional stakeholders and citizens.

Several theoretical frameworks and methodologies have been laid down by researchers to evaluate the suitability for performing the tasks using information systems from a user's point of view (Venkatesh et al., 2003). One of the earliest models to be developed is the Technology Acceptation Model (TAM) formulated in the 80 's to measure factors that explain acceptance and use of information technology for business application (Davis, 1989). Presently, adaptation to the original model has been undertaken by researchers to suit it to modern developments in information technology. Another widely used model is the DeLone and McLean (D\&M) Information Systems Success Model as a framework and model for measuring the complex dependent variable in information system research. The original model has been subsequently adopted and validated through evaluations undertaken for a wide range of information systems. Later DeLone (2003), took note of its widespread use by researchers and updated the original model which was called the updated D\&M IS Success Model. As regards the formulation of specific evaluation models focusing on evaluating the functionality and effectiveness of decision and planning support systems, Adelman (1992) dealt in detail with possible methods for performing evaluations of decision support systems and how they can be incorporated into the development stages to improve their overall functionality. The following methods were distinguished: 1 . Technical methods that include 
tests for measuring the technical aspects of the system; 2. Empirical methods that include tests for measuring the performance of the system and its users, ie. if the decision making ability of the user is improved; 3 . Subjective methods that measure how the system is perceived by users in terms of utility with respect to solving a specific problem. Papamichail (2005) discusses in detail about the application of several of these methods in context of evaluation of the RODOS intelligent DSS for management of nuclear emergencies. These include panel based evaluation, turing tests, validation of expert systems and models, system comparisons and assessing the quality of a decision. 


\section{Chapter 3 - The Indian Context ${ }^{\ddagger}$}

This chapter focuses on the governance of technological risk in India, and critically appraises the regulatory, institutional and management framework for managing technological risks in order to be able to identify the gaps and provide likely solutions which can bridge these gaps and make way for a safer society in India. Haldia, the case study area is also discussed at the end of this Chapter.

\subsection{Policy, Regulatory and Institutional Context}

\subsubsection{Policy Framework for Industrial Risk}

Traditionally, the policy framework of the Government of India has focused on policy formulation from the sectoral perspective. Typical examples are the economic policy statements, transportation policy, rural development policy etc., which are then supported by different national and state level plans and programs. The need for policies for environmental protection and resource consumption was only felt around the early nineties. Accordingly, the 'National Conservation Strategy and Policy Statement on Environment and Development and Policy Statement for Abatement of Pollution' was formulated in 1992. This policy outlines some fundamental principles to balance economic growth with sustainable development goals in line with the mandate of the Rio Summit 1992. However, the scope of the policy was considered to be too broad and not providing any specific direction on how such goals were to be attained. As a result, the policy had no pronounced impact on improving environmental governance. Moreover, in spite of the Bhopal disaster, the policy did not mention or show any direction to be adopted for attaining effective management of industrial risks. Subsequently, when the need for a common ground policy was felt to cover all environmental issues, the National Environmental Policy(NEP) of 2006 was formulated (GoI:MoEF, 2006). Unfortunately, the NEP does not place enough emphasis on the management of industrial risks either.

The NEP also followed similar trends like its precursor policies and lacks specific focus or direction on several aspects. Many of the principles stated in the policy essentially read like a listing of global best intentions rather than being directed at specific issues and conditions in the country, characterized by degradation of environment and high risk levels that prevail in many

¥ Sections of this Chapter are based on a published paper (Sengupta et al., 2016), An evaluation of risk assessment framework for industrial accidents in India, Journal of Loss Prevention in the Process Industries, which has been co-authored as a part of this $\mathrm{PhD}$ research. 
industrial areas which are also listed as pollution hotspots. In spite of the fact that specific emphasis was provided to the adoption of the 'precautionary principle', it's jurisdiction appears to be more from the point of environmental protection rather than the aspect of industrial risk. Further detailing the concept, the principle goes on to mention that "where there are credible threats of serious or irreversible damage to key environmental resources, lack of full scientific certainty shall not be used as a reason for postponing cost-effective measures to prevent environmental degradation". However, for a country like India witnessing developmental pressures resulting from fast pace of economic growth, implementing development plans based on the precautionary principle can be extremely challenging. First, in the realistic sense, without specific guidance, it is difficult to ascertain what presents a 'credible threat' especially when the concept of risk is intrinsically linked to the probability of occurrence and wherein design principles in industries generally take into account that an accident with high damage potential has lesser probability of occurrence. Second, application of such an approach in industrial towns which house large clusters of chemical industries would essentially make these industrial areas unfeasible and would lead to prohibition for any further industrialization.

It needs to be mentioned that a Disaster Management Policy (DMP) has been formulated more recently in India (GoI:MoHA, 2009). Again, there is no added focus or strategy for managing the risks that may arise in MAH industrial clusters. The DMP introduces a policy to reduce risk from various kinds of hazards or to create a mechanism that assists in minimizing damages, but only if a severe accident unfolds.

\subsubsection{Regulatory Framework for Industrial Risks}

After being a party to the Stockholm Convention, the government of India formulated several environmental regulations starting with the Water Act of 1974. Additional impetus to broaden the portfolio of regulations to cover issues like industrial hazards and risks was prompted primarily by the Bhopal disaster of 1984. However, the initial regulatory framework on chemical safety can be traced back to chemical class-specific regulations like the Explosives Act, 1884; the Petroleum Act, 1934; the Factories Act, 1948, the Inflammable Substances Act, 1952; the Insecticide Act, 1968 and Static \& Mobile Pressure Vessels Rules, 1981, etc. The focus of these pre-Bhopal regulations was mainly limited to on-site safety of the workers. Whereas, a legal system to regulate off-site emergency, safe storage and transportation of hazardous materials hardly existed.

Learning the lessons from the Bhopal accident made it imperative for the government to create an overarching legislative framework, the Environment (Protection) Act of 1986. Prior to the Bhopal incident, the Factories Act of 
1948 was the major Indian law that dealt with worker's welfare and health. After the promulgation of the Environment Protection Act, additional impetus was put forward to further broaden the regulatory framework (or portfolio of regulations) to encompass issues like industrial hazards and risks caused by chemicals and wastes, which were earlier not considered to be a priority. Drawing the powers conferred by the Environment (Protection) Act, a comprehensive set of regulations in the form of Rules focussing on the management of hazardous substances, was enacted. The key rules in this context are the Manufacture, Storage, Import of Hazardous Chemicals Rules (MSIHC) notified in 1989 (amended in 1994 and 2000); and the Emergency Planning, Preparedness and Response to Chemical Accidents (EPPRCA) Rules notified in 1996. The overall regulatory framework for chemical risk management is presented in Figure 3-1.

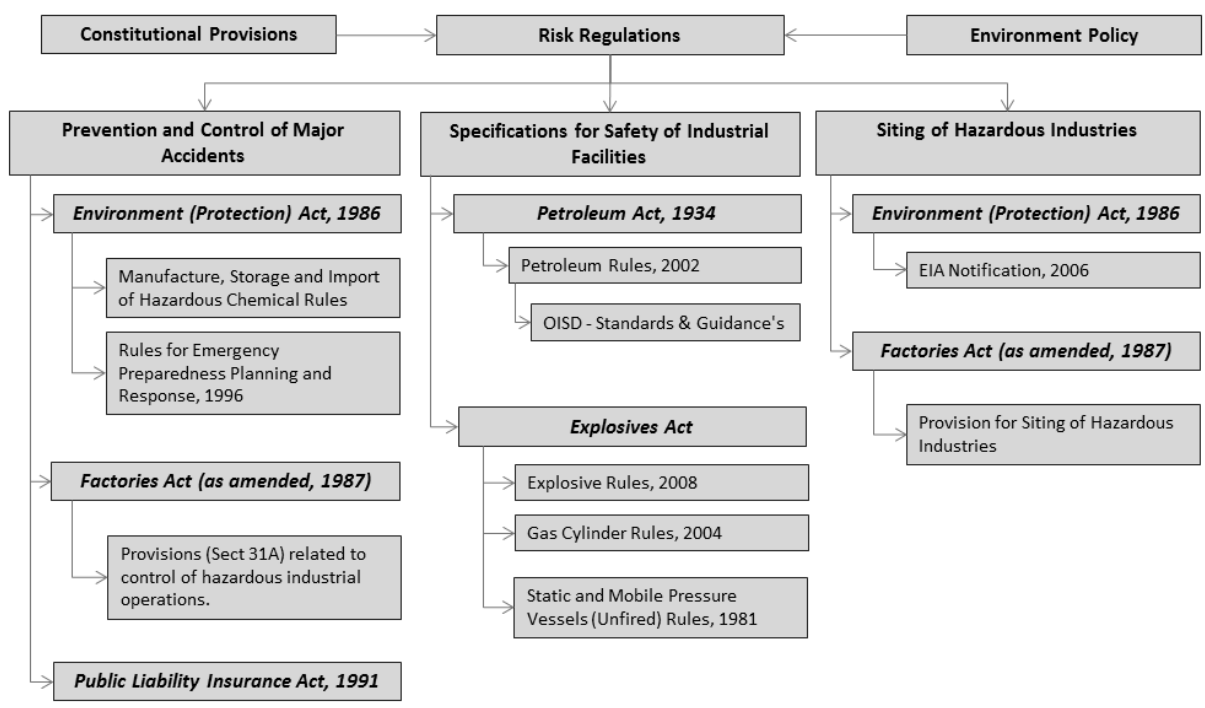

Figure 3-1: Regulatory Framework for Industrial Risk Management in India

Drawn up on the model of the Control of Major Industrial Hazards regulation of the UK, the MSIHC Rules were notified in 1989 under the powers conferred by the Environment Protection Act to widen the scope and provide for additional requirements. The principles objectives of the rules are the prevention of major accidents arising from industrial activities, the limitation of the effects of such accidents both on man and on the environment and the harmonization of various control measures and agencies to prevent and limit major accidents. Industries storing or handling more than a certain threshold of hazardous chemicals (as mentioned in the Schedules of the Rules) are categorised as MAH industries. The MAH industries have to fulfil a number of obligations in order to ensure that they are in control of hazards and risks 
that may originate from the facility and ensuring the public is informed about suitable safety measures to be adopted in case of an accident. Following are the key requirements:

- Take necessary precautions to prevent major accidents and limit their consequences to humans and the environment;

- Bring, major accidents involving the release of major emissions, fire or explosion linked with a hazardous chemical that has the potential to cause substantial loss of life and property or adverse impact on the environment, to the notice of concerned authorities;

- Prepare safety reports on that industrial activity and submit them to competent authorities;

- Prepare an On-Site Emergency Plan;

- Inform the public about the accidents that might occur and the do's and don'ts in case of particular accidents;

- Provide assistance in the preparation of an Off-Site Emergency Plan in accordance with guidelines provided.

Keeping in view the vastness and the highly populated nature of the country and multiplicity of authorities, another scheme for the control of hazardous and toxic chemicals with three levels of controls were prescribed for industries. Accordingly, the EPPRCA Rules was notified in 1996, as a complement of the MSIHC Rules, envisaging a four-tier crisis management system of the country involving the Central Crisis Group, the State Crisis Group, the District Crisis Group and the Local Crisis Group to manage emergencies arising out of industrial operations. Effectively, the EPPRCA Rules thus provides statutory backup for setting up of Crisis Groups at various levels to ensure the management of risk arising out of MAH installations across the country.

In advance of the MSIHC and EPPRCA rules, the Factories (Amendment) Act came into force with effect from 1st January 1987, which introduced special provisions on hazardous industrial activities in the backdrop of the Bhopal Gas tragedy and the Supreme Court's judgment in the Shriram gas leak case. The Act was amended to establish safeguards for the use of hazardous substances by facilities. The amending Act has conferred significant powers on the Factory Inspectors with the objective of implementing the safety provisions of the Act. In conjunction with the Factories Act of 1948, most of other acts of the pre-Bhopal era were amended to strengthen the safety and disaster prevention related provisions. In addition, provisions of existing regulations like the Factories Act and Rules, the Petroleum Act and Rules, the Explosive Act and subsidiary Rules that were concerned with regulating safety performance of industrial operations and plants involving hazardous operations or handling of the hazardous chemicals and explosives were strengthened. 
Other regulations like Petroleum Rules complemented by OISD Standards and Guidelines provide industry specific criteria with regard to operational procedures, maintenance of safety distances between storages and safeguards for processes and equipment's. The Petroleum and Natural Gas Regulatory Board (PNGRB) have also promulgated Codes of Practices for Emergency Response and Disaster Management Plan for petroleum and natural gas industries. The Codes stipulates that all such industries would carry out a systematic risk assessment to identify potential failures, calculate a combination of potential consequence and probability, evaluate the risk based on maximum tolerable risk criteria, and adopt measures to keep the risk "as low as reasonably practicable (ALARP)".

\subsubsection{Institutional Framework}

The Indian governance framework has a federal system that is characterized by four principal tiers of institutions - central, state, district and local. The responsibility for control and management of risk from hazardous industries is dispersed amongst multiple organizations, which come under the ambit of several line-ministries and authorities both at central and state level. Figure 3-2 shows the institutional framework.

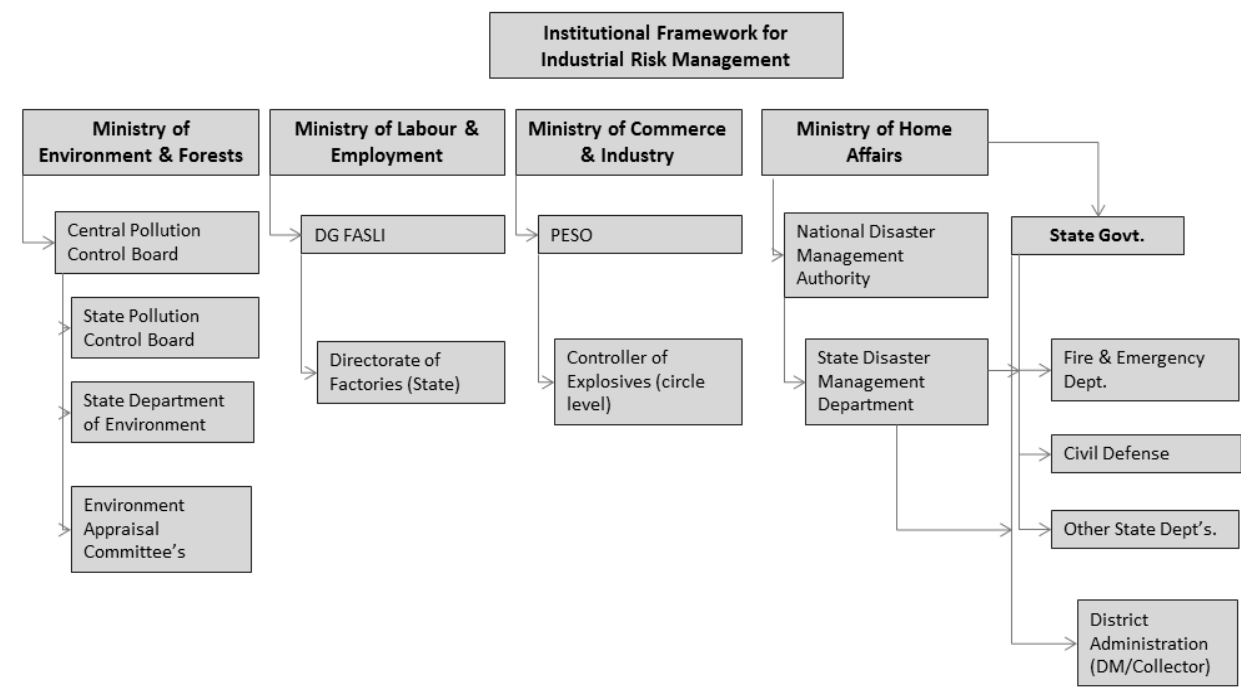

Figure 3-2: Institutional framework for Industrial Risk Management in India

At the federal level, the Ministry of Environment, Forests and Climate Change (MoEFCC) acts as the nodal ministry for instituting and implementing the regulatory framework. This is because in India the whole gamut of laws for hazardous chemicals is formulated under the Environmental (Protection) Act Act, 1986. Within the Ministry, the Hazardous Substances Management 
Division (HSMD) is the nodal point for management of chemical emergencies and hazardous substances. The main objective of the HSMD is to promote safe management and use of hazardous chemicals and wastes, in order to avoid damage to health and environment. The Division also acts as the nodal point for the implementation of the International Conventions like the Basel Convention, the Stockholm Convention and the Rotterdam Convention. Other federal agencies are also responsible for enacting and monitoring compliance of risk related regulations:

the Central Pollution Control Board(CPCB) under MoEFCC;

the Directorate General, Factory Advice Service and Labour Institutes and the Directorate of Industrial Safety and Health under the Ministry of Labour and Employment;

the Petroleum and Explosives Safety Organization under the Ministry of Commerce and Industry,

the National Disaster Management Authority(NDMA) under the Ministry of Home Affairs.

Similarly, at the state level, such responsibilities and roles are primarily led by the State Pollution Control Boards (SPCBs) under the state Department of Environment, and by the Inspectorate of Factories to implement the Factories Act. In a nutshell, the power for regulating and enforcing the laws and rules pertaining to industrial risk management, is dispersed between many organizations at central and state levels.

There are several weaknesses in the existing institutional framework:

- First, there is an absence of an independent regulatory body (other than the competent authority) to assess the overall effectiveness of the system.

- Second, there is no structured and clear hierarchy to comprehend the institutional mechanism as well as the role of individual organizations.

- Third, the multiplicity of institutions to deal with permitting, reporting and inspection for industrial risk aggravate the compliance problem. With the number of institutions at different levels, there is often a lack of both horizontal and vertical coordination between the agencies. In the vertical chain, there is more a tendency of central and state level agencies to get into a conflict.

- $\quad$ Fourth, there has been a lack of adequate institutional capacity at both the nodal (MoEFCC and CPCBs) and implementation level (SPCBs and others) to match the demand for compliance services as a result of a steady increase in the numbers of the regulated community and the complexity of environmental issues that are being encountered. 


\subsection{Planning Context}

Presently, there is lack of comprehensive and integrated land use planning in the country, which enables rationale and optimal land utilisation. There is also no single approach currently being followed across the country. Various sectors at central level such as urban, rural, industrial, transport, mining, agriculture etc. follow their own approaches. The Constitution (Seventyfourth Amendment) Act, 1992 provides for District Planning and Metropolitan Area Planning that consolidates plans of both Panchayats and municipalities with regard to spatial (land use) planning. District plans are prepared at a higher scale currently do not cover spatial (land), environmental or urban concerns. For urban development areas, a land use control development plan (LUDCP) is to be prepared and updated, as per the requirements of the respective State level Town and Country Planning Acts - however, implementation of the local zoning and land use restrictions have been quite ineffective in most of such planned areas (GoI:MoRD, 2013).

The recently formulated Draft National Land Utilisation Policy, aims to provide a framework for land use planning and management, recognising that economic, developmental, social and environmental needs are to met through rational and sustainable use of land (GoI:MoRD, 2013). According to this draft policy, all land in the country will be classified into Land Utilisation Zones (LUZs) like rural areas, agricultural areas, industrial areas, etc. and to undergo land use planning for one or more objectives. Further, for the purpose of land management, LUZs are to be divided into various Land use Management Areas (LMAs) to ensure protection, regulation, control and guided development. The planning process in these LUZs is expected to be guided by the newly drafted Urban Development Plans Formulation and Implementation (UDPFI) Guidelines which recommends the adoption of a tiered planning process comprising of preparation of a perspective plan followed by development plans and annual plans (GoI:MoUD, 1996). Recently, several initiatives have been made to democratize local urban planning. Comprehensive Development Plans and Draft Development Plans for a large number of urban local bodies have been prepared at the urban local body (ULB) level, with provision for proactive involvement of the public in the planning process and in the discussion of planning alternatives and schemes.

In order to ensure proper siting of newly planned industries taking into account environmental considerations, a project called the "Zoning Atlas for Siting of Industries" has been implemented through the apex pollution control authority in the country - the CPCB (Punihani et al., 2002). The project lays down a methodology for preparing thematic maps at district level factoring aspects like prevailing air, water and ground water quality and undertaking 
multi-criteria based sensitivity analysis for assessing suitability for new industries at a district level. Using a standard methodology, zoning atlas maps for several districts in the country have been prepared and are available as hardcopies from the CPCB. However, the Zoning Atlas methodology did not incorporate chemical risks in the siting analysis. Also, the use of Zoning Atlases for planning of new industrial areas has been inadequate and the tools and methods drafted as a part of the Atlas have not so far been mainstreamed with the planning process or adopted by planning authorities at the state or district levels.

A good case in point is the emergence of more than 100 industrial clusters in India which houses a significant portion of the country's hazardous industries. When some of the first hazardous industries came up in these clusters, in areas demarcated for industrial development as a part of a centralised planning process, there was limited local population and therefore, low risk to society in the eventuality of an industrial accident. However, as these industrial areas expanded and new industries came up, they witnessed a rapid in-migration of people cohabiting beside hazardous industries, made possible by weak land use controls and leading to a significant amplification of risk (Porto et al., 1996). While creating sufficient separation distances between such facilities and residential areas could have provided for a straightforward resolution of the problem, such decisions were difficult to implement in rapidly urbanising areas where land availability is constrained. Consequently, on one side, land-use planners have to account for the safety of the surrounding population in an industrial area. On the other, they have to consider options to exploit land in the best possible manner accounting for socio-economic considerations like employment opportunities, benefits to the local community from operation of an industry and objectives for area level industrial development (Gupta et al., 2002). As a result, the desire for short term and tangible developmental gains has often prevailed over notions of anticipated safety benefits to communities in the long-run.

Therefore, it can be concluded that regulatory provisions for control of industrial risk have seldom been taken into account in land use planning and in the design or the adoption of community-level preventive measures for risk reduction (GoI:NDMA, 2007). Several regulations like provisions of the Environment Protection Act, the EIA Notification and the Factories Act, along with associated Rules and codes of practice have been formulated to provide directions for safe siting of industries. However, there has also been no attempt to interlink the technocratic approach adopted for hazard analysis, predominantly through the setting of appropriate safety distances, with the land use planning practice adopted by developmental agencies and urban local bodies (ULBs). As a result, planners faced with pressures to use land for productive purposes are often not aware of such land use restrictions or 
without having a stringent restriction imposed by the competent regulator, are not been able to justify the exclusion of privately owned or public land from future development.

\subsection{Information System Context}

\subsubsection{ICT \& NSDI in India}

India is fast emerging as a global player in the field of ICT. In order to effectively use technology-based interventions to deliver on development goals, the government has initiated a large number of ICT projects to improve e-governance. However, many of these earlier projects focused on one-way flow of information in a government to citizen mode with few opportunities being provided for two-way transactional governance (Thomas, 2009). A review of several past projects like Bhoomi, Gyan Ganga and others show that they have encountered considerable hurdles in implementation, being caused by the tools not being networked and the inability of multiple agencies to leverage information from the system for productive purposes (Bhatnagar et al., 2005; Puri et al., 2007). On the GIS front, considerable difficulties were experienced in the 1990's and early 2000's with GIS applications with few reaching their desired potential. Government agencies like the Indian Space Research Organisation (ISRO) and the Survey of India (SoI) acted as powerful custodians of data, allowing for limited sharing with other government institutions and to the private sector and citizens citing security concerns. Several projects with similar objectives, for example the National Natural Resource Management System (NNRMS) by ISRO and National Resource Data Management System (NRDMS) by the Department of Science and Technology (DST) were launched, and they functioned in a compartmentalized manner with little interaction and sharing of data (Georgiadou et al., 2005). Researchers reviewing such projects pointed to several problems: institutional inadequacies leading to lack of continuity in project management; the involvement of multiple actors who preferred working in a compartmentalized mode; strong bias not to take into account social aspects involved in implementing a project of this nature; and absence of comprehensive and sustainable data management strategies (Barrett et al., 2001; Sahay et al., 1996; Walsham et al., 2006).

India initiated the National Spatial Data Infrastructure (NSDI) project in 2001 with the aim of making available spatial data sets to user groups to assist in developmental planning, natural resource management, land use assessments and disaster management amongst other uses. To this effect, a NSDI Strategy and Action Plan was drafted and key elements for development of the NSDI were identified as interoperable standards data and networks, GIS-based spatial database server nodes, search and access protocols, electronic clearing houses, user interfaces and an NSDI outreach 
and awareness programme. The initial NSDI strategy proposed to equip participating nodes like the Survey of India, Geological Survey, Census Survey, Forest Department, Urban Development and other departments with a NSDI node comprising of GIS database servers to store department specific geospatial data, which would then be interconnected through a master NSDI server over the internet (Nag et al., 2008). As a part of the NSDI development process, a technology centric approach has been followed and several documents like the NSDI Content Standard, NSDI Metadata Standard, Networking Framework, etc. were prepared indigenously through interagency coordination to facilitate its development. Based on this groundwork, a NSDI portal was launched in 2008, but serving only limited spatial data for the country (Singh, 2009). The NSDI initiative has also been criticized for adopting an overtly centralized and top-down planning approach involving the framing of standards, metadata, search/ access protocols and planning for the overall architecture in terms of server and networks to support the requirements, with little evidence of systematic interaction with potential end-users (Georgiadou et al., 2005). Sharp differences also emerged in perceptions between the government nodal agencies, the geo-spatial industry and the prospective users of the NSDI (Puri, 2006). Proposed user communities also point to the fact that the NSDI program is unlikely to serve their spatial data requirements which can be a used as inputs for analysing developmental planning projects like roads, telecommunication, infrastructure, etc. or for studies like environmental assessments (Singh, 2009).

\subsubsection{ICT for Industrial Risk Management}

Emerging policy and regulations in India are increasingly focusing on adopting a more risk-informed approach where risk actors have access to relevant information that can assist them in managing risk originating from hazardous industries (GoI:MoHA, 2009; MoHA:GoI, 2004). An example of an online database is the India Disaster Resource Network (IDRN), which contains a nation-wide electronic inventory of resources enlisting equipment and human resources, collated from district, state and national level Government line departments and agencies. This database is monitored and maintained at the central level by the National Institute of Disaster Management (NIDM) (MoHA:GoI, 2004). In the specific domain of industrial risk management, there is no publicly available database which can provide hazard and risk information to relevant risk actors. Additionally, as there are no updated high-resolution maps available with the regulatory and planning agencies, the understanding of the spatial distribution of the exposed and vulnerable population is low. One of the first initiatives to build an online web GIS commenced as a part of the ERRIS project. This initiative was initiated by the industries through an industry organisation - Indian Chamber of Commerce in the State of West Bengal. It supported the voluntary reporting 
of industrial hazards, but its implementation has been limited only to two industrial towns in the country (Bandyopadhyay et al., 2008). The MoEFCC has initiated the development of a web-based GIS for Emergency Planning and Response (GEPR) tool which is being implemented for select industrial clusters in the country (Gahlout et al., 2009), but the system is specifically tuned for emergency response. Presently, the GEPR has limitations in terms of providing appropriate resolution of data, does not have any provision for online update of data and provides limited access to various risk actors.

\subsection{Case Study Area - Haldia}

The case study area which is taken up for the design and development of industrial risk information, decision and planning support system is the industrial town of Haldia, located in the eastern part of India. In order that the application context of the proposed systems is understood in the correct context, it is necessary to provide a brief description of the case study area.

The industrial town of Haldia was selected as case study of this research because of two key considerations. The first relates to the importance of the industrial town as a rapidly growing chemical industry hub in the eastern part of the country, which is faced with key challenges with respect to management of industrial risk, from the governance context. The second reason is the familiarity acquired with the planning and institutional setting, the risk management actors, the spatial configuration and understanding of prevailing risks during the implementation of the ERRIS project, which forms a precursor to this research. 


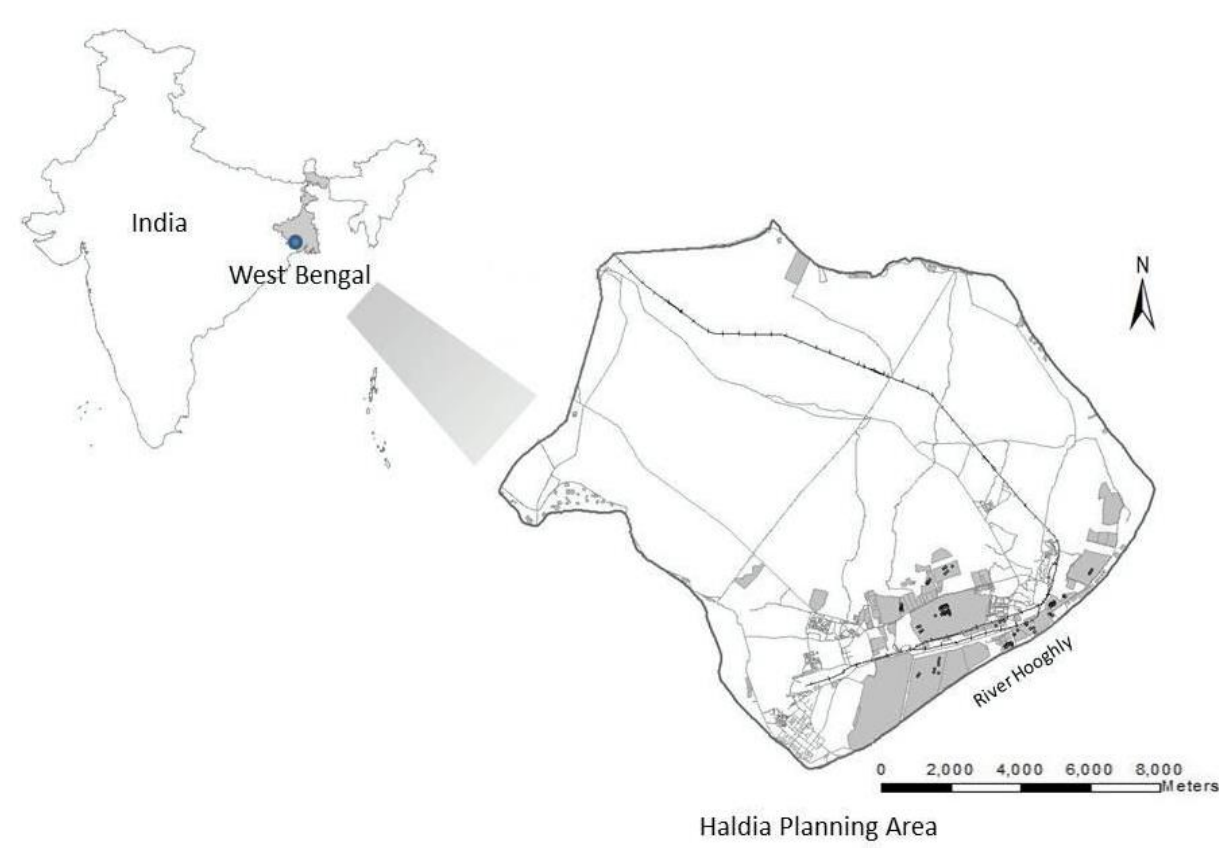

Figure 3-3: Location of Haldia Planning Area, India

Haldia is located in the southern part of the state of West Bengal in eastern India. It comprises about $761 \mathrm{~km}^{2}$ of area forming the Haldia Planning Area. Physically, the land mass of Haldia falls within lower riverine plains of one of the major rivers flowing through the eastern part of the country, the Hooghly. Situated in the deltaic reaches of the river, it is located on a peninsula like-area, which is bounded by three rivers. As a result, there is very intense pressure on land resources. The altitude varies between 2-4 m above mean sea level. Although there are no records of natural disasters hitting the area in the recent past, the region is prone to cyclonic storms and tidal surges. Some localized flooding has also been witnessed in low-lying areas of Haldia during the heavy rainfall months.

Since the commissioning of the port in Haldia in the early 1970's, industrial development in the area has occurred at a rapid pace. With the setting up of the port and the onset of industrialization, the land-use of the predominantly rural area started to change considerably. At present, the city has developed into a large industrial cluster with more than $20 \mathrm{MAH}$ units and about 40 other industries. The industries attracted population from the neighbouring regions and districts leading to the gradual urbanization of the area. The urban area of Haldia has a population in the range of about 0.15 million inhabitants based on data from 2006, with a considerable percentage living in close proximity to the hazardous installations, therefore being highly vulnerable to the impact of a potential industrial accident. The population of 
the area has increased significantly over time since the industrialization and urbanization process commenced a few decades back. In terms of connectivity, the main access to Haldia is through either a four lane national highway or a state highway that runs parallel to each other for most part. The city is also connected by rail, which branches off from one of the major railway corridors in the region passing about $50 \mathrm{~km}$ to the north-west. The area has also grown as educational hub with a large number of institutions and professional training institutes which have come up to support the need for skilled manpower in the industries. In addition, a number of healthcare facilities and hospitals have also recently come up in the city.

From the planning point of view, Haldia and the surrounding hinterland is a densely populated region with average population density of 904 persons per $\mathrm{km}^{2}$ resulting in a citizen to have an average of only about 0.11 hectare of space around him. Haldia and its adjoining region, comprising of about 786 $\mathrm{km}^{2}$ in total, has been declared as a planning area under the West Bengal Town and Control Planning Act. Resultantly, the planning and development of the area, including land-use planning, land management setting of infrastructure, etc. is managed by the Haldia Development Authority (HDA). The area is overall governed by the District administration and the block development offices which represent the Tier 3 of the Indian administrative hierarchy. The local government in rural areas of Haldia comprises of Gram Panchayats and the urban area comes under the Municipality.
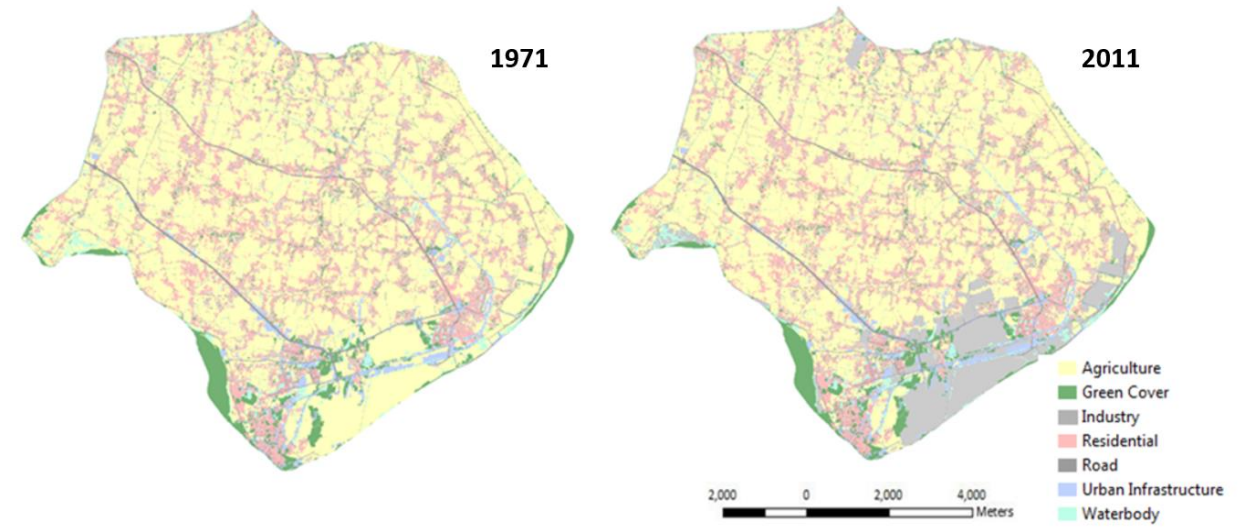

Figure 3-4: Land use changes in Haldia from 1971 to 2011

With a surge in the number of hazardous industries coming up and the gradual in-migration of people, the industrial risk level in Haldia is expected to rise further. Till date, potential risks arising out of hazardous industries have never been previously factored into the land use planning process or the overall development of the region. No effort has been made to maintain any 
exclusion or separation distance of residential areas or informal habitations from hazardous industries. As a result, populated areas often co-exist with hazardous industries side by side resulting in very high vulnerability to the residents of the city.

Interactions with stakeholders indicate that they do not have a deep understanding of the complex factors that may influence decisions on issues like risk or sustainability planning. Stakeholders also display diverging opinions: some of them are in favour of further industrialization while others want more security from the risks originating from the hazardous installations. Therefore, there is a need for a process where stakeholders come together and communicate their views leading to a conceptualization this complex decision problem through a participatory process. During the implementation of the ERRIS project at Haldia in the period $2004-06$, several workshops were conducted to elicit participation of risk actors in understanding the potential hazards from $\mathrm{MAH}$ industries and related vulnerabilities to population, infrastructure and environment. During these workshops, the stakeholder groups, comprising of planning authorities, industry organizations, and community interest groups expressed their interest to participate in initiatives for reduction of industrial risk in the area. A follow-up workshop with the objective of developing stakeholder consensus on delineation of areas for future development of industrial and residential zones was held in December, 2011 and the results of the workshop are discussed in a later section.

In general, while the response of the stakeholders to such a consensusoriented approach was quite positive, the lack of flexibility provided by traditional planning tools to quickly generate risk and suitability maps taking into account multiple choices and preferences was cited by many participants as a key hurdle. In addition, stakeholders do not yet have access to tools which can facilitate efforts in undertaking exploratory analysis of planning scenarios in a collaborative and participative manner and contribute to, for example, a sustainable land-use planning decision of their neighbourhood. Feedback from the workshop indicated that participants would prefer reduced complexity and improved efficiency through an appropriately designed spatial planning tool. 


\section{Chapter 4 - The Industrial Risk Management Information System}

This Chapter discusses the framework for a web-GIS based information system for storing and managing industrial risk and related information.

\subsection{Introduction}

The lack of appropriate hazard and risk information amongst relevant stakeholders can be a key factor causing higher than expected damages from an industrial catastrophe, as demonstrated in many historical cases like Bhopal, Mexico City, Toulouse and Enschede (Ayres et al., 1987; de Freitas et al., 2001; Jasanoff, 1988; Porto et al., 1996). These incidences have shown that limited information has resulted in: lack of awareness on potential hazards amongst communities vulnerable to industrial risk; inadequate emergency preparedness plans amongst administrators; inappropriate land use plans in the vicinity of highly hazardous industries, thereby resulting in significantly higher damages to life and property in case of a disaster.

To account for such needs of information availability, regulatory requirements for industrial risk management in Europe have been formulated under the umbrella of the Seveso Directive. Further, country specific regulations like the COMAH in UK, the External Safety Policy in the Netherlands and the Emergency Planning and Community Right to Know (EPCRA) in the US, provide specific provisions for sharing information with risk actors and the public (De Souza Jr, 2000; O'Mahony et al., 2008; Walker et al., 1999). In India, emerging policy frameworks are increasingly focusing on adopting a more risk-informed approach where risk actors have access to relevant information on industrial hazards (MoHA:GoI, 2004). Ensuring the availability of major industrial hazards related information to risk actors has also been mandated by several safety and emergency regulations: the EPPRCA, MSIHC, DMP (GoI:MoEF, 1996, 2000; MoHA:GoI, 2004).

In order to cater to the need for sharing information pertaining to industrial hazards and risk with relevant stakeholders, several initiatives were taken up in countries like UK and Netherlands which are leading in industrial risk research (Basta et al., 2007). However, not all the systems like the SPIRS in Europe and risk databases of UK HSE were planned to make information available to all stakeholders, with the Risicokaart in the Netherlands being a notable exception (Risicokaart.nl). In India, as a part of this research, the first effort to develop and deploy an online web-GIS was the ERRIS project and was recognised as a key technical initiative in the National Guidelines for Chemical Disaster Management (Bandyopadhyay et al., 2013; GoI:NDMA, 2007). Implemented for the industrial towns of Haldia and Durgapur in the 
State of West Bengal, the success of the ERRIS project hinged upon the voluntary reporting of industrial hazards by MAH industries. As the nodal regulatory agency for control of chemical hazards, the MoEFCC has also initiated the development of a web-GIS tool for storing data on fixed hazardous storages and potential hazard scenarios that can originate from such sources (Gahlout et al., 2009).

Experience on application of existing risk information systems and databases has shown that sharing of vital information is hindered by lack of common policies, procedures and standards leading to incompatibility between systems and resulting in owner organisations and users not leveraging the full benefit from such ICT solutions (Annoni et al., 2005; Kevany, 2003; Mendonça, 2007). In order to resolve these problems, increasingly Spatial Data Infrastructure's (SDIs), providing open, linked, free-flowing and accessible data, are being considered as preferred platforms for sharing of risk and disaster related information at national and international levels (Fabbri et al., 2005; K"ohler et al., 2006; Mansourian et al., 2006). For now though, there are no SDI based information system that focuses on industrial risk information integrating data from hazardous industries, response agencies, vulnerable population and elements at risk, meteorology sensors and transportation networks.

The objective of this chapter is to outline an information system framework for industrial risk management in India, centred on an SDI, that allows for interoperability of data and is also capable of providing decision support services. This conceptual model includes: identifying data requirements; creating an abstract data model of feature types, attributes and relationships of industrial risk management data; service oriented architecture for hosting the system; and a platform for hosting decision support services for guiding risk management decision making in various phases. Based on this conception, a web-based prototype Risk Management Information System (RMIS) will be designed and tested as a tool for data sharing, exchange and supporting user queries.

\subsection{Framework for Industrial Risk Management Information}

\subsubsection{Industrial Risk Governance \& Information Requirements}

The approach to industrial risk governance proposed in this research accounts for an information oriented approach and supporting tools to reduce the complexity of the decision problem and support decision making in a transparent and participative manner. Logically then, industrial risk governance is expected to focus on management objectives related to the reduction of risk arising from hazardous industries, the storage and 
transportation of hazardous chemicals, which are to be attained with the cooperation of risk actors - primarily, government agencies, hazardous industries and the community. A risk management problem in an industrial area having a high exposure to such risks requires an integrated approach, aiming at consensus and acceptance amongst risk actors and stakeholders.

For an integrated framework for risk management, it is essential to have an understanding of the information requirements of key stakeholders or risk actors across different phases of the risk management process (i.e. from preparedness, response to mitigation). Only then, the various risk actors will be able to coordinate and arrive at decisions for risk prevention and mitigation in a transparent manner. As a starting point, two key aspects need to be dealt with: first, a common understanding of risk from the point of view of industrial hazards needs to be adopted; and second, the risk actors and their respective information requirements need to be identified.

Risk can be defined as a measure of human injury, environmental damage or economic loss in terms of an incident likelihood and the magnitude of loss or injury, which can be expressed as the following function:

$$
\text { Risk }=F(s, c, f)
$$

Where, $s=$ hypothetical accident scenario, $c=$ estimated consequence(s), $f$ = estimated frequency (AIChE/CCPS, 2000). The main concepts of the industrial risk are illustrated in Figure 4-1 in the perspective of the study area.

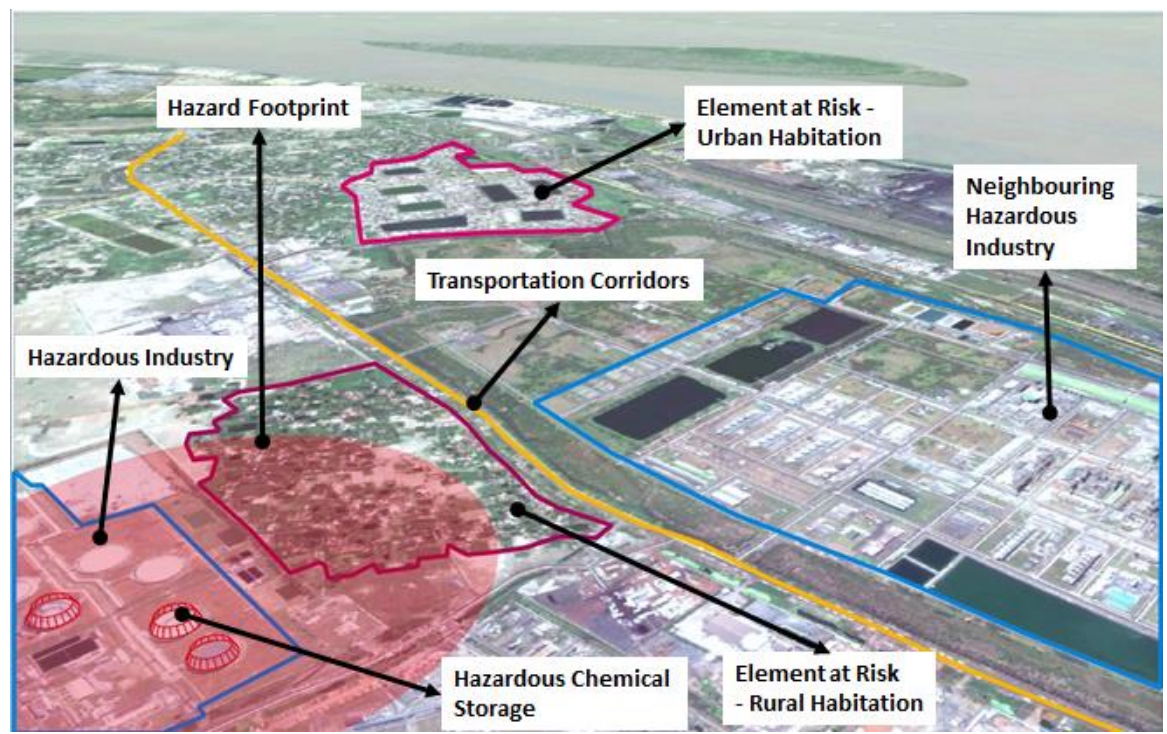

Figure 4-1: Main Concepts of Industrial Risk in Perspective of Haldia 


\subsubsection{Conceptualizing the Industrial Risk Geo-portal and SDI}

Presently in India, risk management and related data is owned and maintained by various government agencies and by the private sector. Such agencies include the district administration, planning agencies, land revenue department, regulators like pollution control boards and factories inspectorate, industries, public utilities and response agencies like fire brigade, police and hospitals. For a number of related domains like cadastre, considerable amount of data still remaining in paper format or are stored in digital formats that do not allow for cross disciplinary use by other departments (Habibullah et al., 2005). The Indian National Spatial Data Infrastructure (NSDI) has not matured to a level where such databases can be expected to have operational compatibility and can made be available through a common geo-portal.

This research proposes to conceptualise an information system framework for industrial risk management - the Industrial Risk Management SDI (IRM-SDI), which could be integrated with the Indian NSDI through a set of common policies, standards and specifications, and accessing the same network. The IRM-SDI will allow for consolidation of multidisciplinary information from heterogeneous sources with the storage, retrieval and presentation of such data managed through geospatial web services (Annoni et al., 2005; Mansourian et al., 2006). Made available through standard web services that can function like reusable software components, these web services will interact with other services within an OGC Web Services (OWS) Architecture, which collectively will be a part of the Service oriented Architecture (SoA) approach (OGC, 2003). Multiple organisations and users are expected to collaborate on the creation and maintenance of the geospatial data that will be made available through the IRM-SDI.

While a generic SDI framework, operating across different levels (National, State, Local), is expected to function as SoA, increasingly it is expected that they will be complemented by context driven SDIs providing relevant geospatial services focusing on a particular theme of data or geographic information that will be deployed at various levels (national, state, local). This Context Aware SDI model is anticipated to function as a set of loosely coupled services and will only provide access to the data or services that are relevant to the context for which it is being proposed for use (Scholten et al., 2008). It will focus on driving high level functions within the active 'industrial risk' context that are exposed to the applications, in the process reducing the dependence on unnecessary complicated domain driven syntax and reducing dependability on underlying services. More specifically, the information and associated scenario-based application services like consequence and risk calculation, modelled through appropriate workflows, will link up existing data 
on vulnerability and call upon other related feature and map services like transportation networks and the cadastre to provide guidance on decision making to the user. Figure 4-2 shows a conceptual representation of the Context Aware Risk SDI comprising of different levels of vertical SDIs (national, regional, local) as well as several possible context specific SDIs. Table 4-1 illustrates the kind of information and processing or application services that could emanate from the individual SDIs, represented through 'diamonds' in Figure 4.2 and could be used separately or in conjunction to provide meaningful data services and web applications to risk actors or decision support functionalities to high level users.

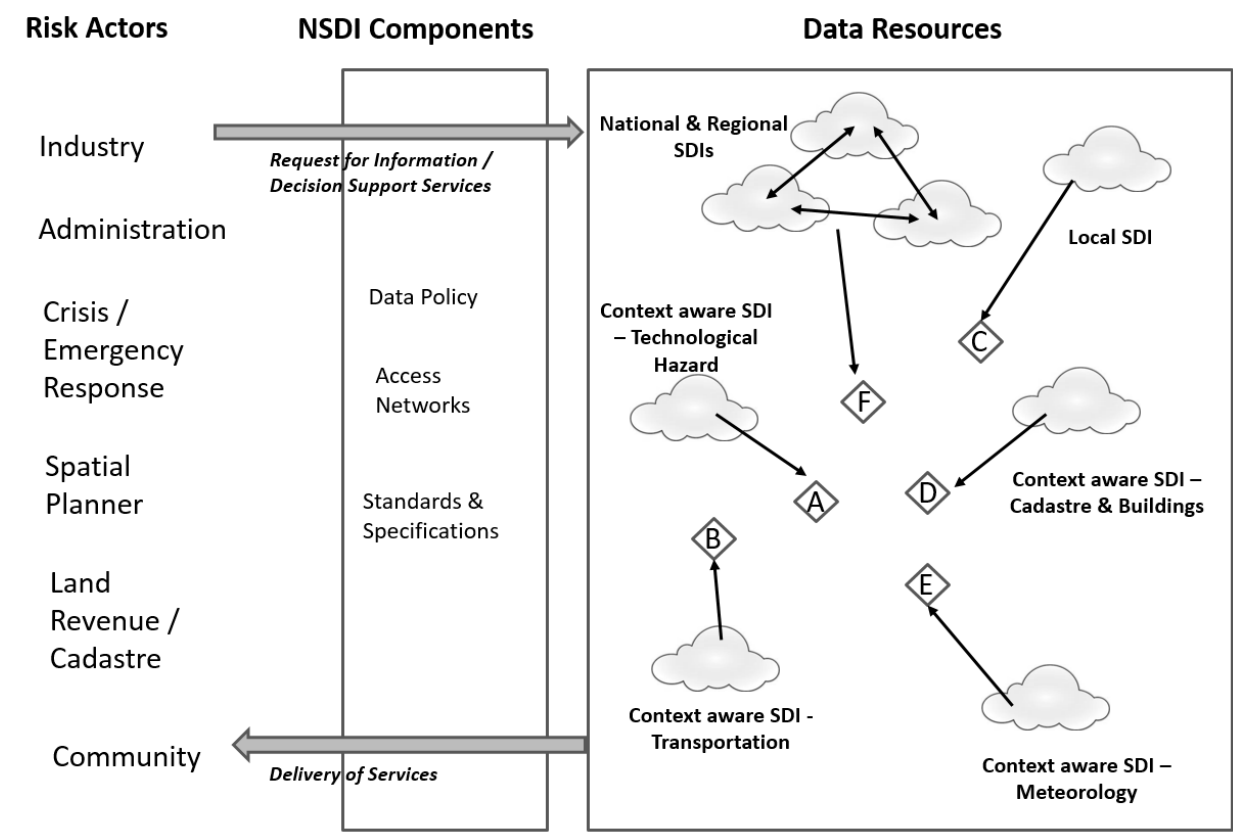

A - Risk /consequence calculation; B - route optimisation; C - local level indicators like distance to school, hospital; D - population in buildings; E - Sensor Data on wind speed and direction; F - Data like Administrative boundaries

Figure 4-2: Concept of Context-aware SDI for Industrial Risk Management in India (Adapted from (Scholten et al., 2008)) 
Table 4-1: Examples of Risk Relevant Services from Context Aware SDI

\begin{tabular}{|c|c|c|}
\hline SDI & $\begin{array}{l}\text { Example Information } \\
\text { Services }\end{array}$ & $\begin{array}{l}\text { Example Processing / } \\
\text { Application Services }\end{array}$ \\
\hline $\begin{array}{l}\text { Context Aware } \\
\text { SDI - Industrial } \\
\text { hazard }(A)\end{array}$ & $\begin{array}{l}\text { Location and information } \\
\text { on hazard sources, } \\
\text { chemicals stored, chemical } \\
\text { properties, process details }\end{array}$ & $\begin{array}{l}\text { Calculation of consequence } \\
\text { for calculation of accident } \\
\text { effect footprints; } \\
\text { Estimation of area risk }\end{array}$ \\
\hline $\begin{array}{l}\text { Context Aware } \\
\text { SDI - } \\
\text { Transportation } \\
\text { (B) }\end{array}$ & $\begin{array}{l}\text { Details on roads - } \\
\text { alignment, length and } \\
\text { width, etc. } \\
\text { Density of vehicles at } \\
\text { intersections }\end{array}$ & $\begin{array}{l}\text { Calculation of optimal } \\
\text { routes for emergency } \\
\text { response } \\
\text { Analysis of accident prone } \\
\text { road stretches for risk } \\
\text { mitigation planning }\end{array}$ \\
\hline $\begin{array}{l}\text { Local level SDI } \\
\text { (C) }\end{array}$ & $\begin{array}{l}\text { Details on administrative } \\
\text { offices, schools, hospitals, } \\
\text { fire brigade }\end{array}$ & $\begin{array}{l}\text { Location suitability } \\
\text { Local level spatial indicators }\end{array}$ \\
\hline Meteorology (E) & $\begin{array}{l}\text { Near real time wind speed } \\
\text { and direction data }\end{array}$ & $\begin{array}{l}\text { Calculation and } \\
\text { representation of wind } \\
\text { vector map over area of } \\
\text { interest }\end{array}$ \\
\hline $\begin{array}{l}\text { National \& } \\
\text { Regional SDI }\end{array}$ & Administrative boundaries & $\begin{array}{l}\text { Calculation of } \\
\text { administrative areas } \\
\text { Regional level indicators }\end{array}$ \\
\hline
\end{tabular}

The IRM-SDI will be front-ended by a geo-portal called the Risk Management Information System (RMIS) which will act as the user interface for the IRMSDI, linking directly and providing online geographic content through a set of native and common geospatial services responding to user needs (Maguire et al., 2005). The RMIS geo-portal will organize content and services as directories, search tools, data and applications community resources and support resources and also provide direct access to raw data in multiple formats, complete metadata, datasets and created maps. The RMIS interface would also provide functionality for setting up complex workflows for risk information processing, application of domain specific modelling, decision and planning support tools and provide for appropriate rendering of results like a risk map through its map based interface.

\subsubsection{Stakeholders Inputs}

Researchers have invested considerable efforts to improve the development practice of tools to support decision making and planning challenges by learning from the professional experience of other developers in academia, government and industry (McIntosh et al., 2011). A review of such experience reveal that a critical step in the design, development and deployment of the risk information, decision and planning support system platform is to ensure acceptability amongst targeted end-users to fulfil respective planning and decision making tasks. Based on a study of organisation of disaster risk management, several researchers have 
suggested classifications of end-users based on type of disaster, role they are expected to play and environments in which they are expected to work (Dilo et al., 2011; Zlatanova et al., 2012). Literature suggests that during the conception of information system that is expected to serve multiple stakeholders, it is a perquisite to clearly identify the end-users and elicit decision-making requirements from them. Experience shows that such an approach leads to a better identification of needs for which the system is proposed, the organisational context within which they would operate and understand the job responsibilities of each party (Elmahdi et al., 2009).

Ensuring stakeholder involvement is an important aspect of the risk governance process. A participatory planning focus for the design and development of the industrial RMIS was undertaken based on foundation laid through the ERRIS project (Bandyopadhyay et al., 2013). A review of the industrial risk management process undertaken during the initial phases of the project suggested that a considerable diversity of information seekers and decision makers at the local, district/state and national level is interested in obtaining key information on industrial risks and vulnerabilities.

In practice, the level of involvement of institutions and stakeholders at the higher level has been found to depend on the magnitude and severity of the risk that was being dealt with. In general, risk based planning involving emergency preparedness and response as well as long-term risk reduction measures involving land use zoning and control in an industrial town like Haldia is the responsibility of local and district level institutions, who in turn have to involve hazardous industries and communities potentially to be affected by such risk. In case the potential risk or accident has the capability to cause significant damage to life and property or if inter-state / regional spread is involved, the lead in managing such risks can be taken up by country level agencies like the MoEFCC and the NDMA. Based on review and discussions undertaken during the ERRIS project, a hierarchy of risk management stakeholders who can be expected to be a stakeholder in industrial risk management was drawn up and represented in Table 4-2. A certain degree of overlap in roles and responsibilities is expected between the different hierarchical levels. 
Table 4-2: Risk Management Hierarchy, Stakeholders and Issues

\begin{tabular}{|c|c|c|}
\hline $\begin{array}{l}\text { Risk Management } \\
\text { Organisation } \\
\text { Hierarchy }\end{array}$ & Stakeholders & Planning Issues \\
\hline National / State & $\begin{array}{l}\text { Policy/Planning Organisations } \\
\text { - Planning Commission, } \\
\text { Disaster Management } \\
\text { Authority, Ministry of } \\
\text { Environment \& Forests, } \\
\text { Department of Environment } \\
\text { National / State level Crisis } \\
\text { Groups } \\
\text { Industry Development } \\
\text { Corporations } \\
\text { Response Agencies - Defence } \\
\text { Forces, National Disaster } \\
\text { Response Force (NDRF) }\end{array}$ & $\begin{array}{l}\text { Policy for industrial risk and } \\
\text { disaster management, development } \\
\text { of industrial growth areas } \\
\text { National legislation for regulatory } \\
\text { control on risk, deciding role of } \\
\text { competent authorities. } \\
\text { Higher level emergency response } \\
\text { strategies/ plans }\end{array}$ \\
\hline District / region & $\begin{array}{l}\text { Regulators - District/ regional } \\
\text { offices of Factories } \\
\text { Inspectorate, Pollution Control } \\
\text { Authority, }\end{array}$ & $\begin{array}{l}\text { Regional developmental planning } \\
\text { goals, population growth and urban } \\
\text { centre planning }\end{array}$ \\
\hline & $\begin{array}{l}\text { District Planning Board \& } \\
\text { Administration } \\
\text { Industrial Estate/SEZ } \\
\text { Authority; Highway and Port } \\
\text { Authorities }\end{array}$ & $\begin{array}{l}\text { Plans for Industrial growth centres } \\
\text { Multi-hazard disaster management } \\
\text { plans }\end{array}$ \\
\hline \multirow[t]{4}{*}{ Local } & $\begin{array}{l}\text { Land Revenue Department } \\
\text { Emergency response } \\
\text { organisations - Local } \\
\text { Emergency Crisis Group, } \\
\text { Industry Mutual-aid Groups, } \\
\text { Fire Department, Police, } \\
\text { Hospitals, Civil Defence groups }\end{array}$ & $\begin{array}{l}\text { Emergency management through } \\
\text { local administration - } \\
\text { preparedness, planning, response } \\
\text { and recovery }\end{array}$ \\
\hline & $\begin{array}{l}\text { Planning Bodies - Urban local } \\
\text { body (ULB), Development } \\
\text { Authority as per TCPA, } \\
\text { Industry management, } \\
\text { Industry associations and } \\
\text { mutual aid groups, } \\
\text { Transporters (rail, road, ship, } \\
\text { pipelines) }\end{array}$ & $\begin{array}{l}\text { Risk reduction strategies, Growth } \\
\text { area land use and allocation plans - } \\
\text { land use controls } \\
\text { Plan for Mutual Aid during } \\
\text { Emergencies }\end{array}$ \\
\hline & $\begin{array}{l}\text { Community - community } \\
\text { organisations, local interest } \\
\text { groups and NGOs }\end{array}$ & $\begin{array}{l}\text { Plans for evacuation / shelter in } \\
\text { place during emergency }\end{array}$ \\
\hline & $\begin{array}{l}\text { Schools, colleges, academic } \\
\text { institutions }\end{array}$ & $\begin{array}{l}\text { Community awareness and } \\
\text { education on industrial risk }\end{array}$ \\
\hline
\end{tabular}

Based on the identification of planning issues in which stakeholders have potential roles to play, a series of workshops and interactions were held within the scope of the ERRIS project to engage stakeholders in deliberations 
and understand first hand their information needs in context of risk management. A phased approach was adopted to build up the stakeholder engagements. In the first phase, the focus of interactions was the MAH industry to discuss about a mechanism to voluntarily share information with other local stakeholders. 18 industries, comprising of the majority of the MAH industries present in Haldia shared information through a 'risk reporting questionnaire'. The second level of interactions was focused on involving the emergency management stakeholders and included the MAH industries, local administration, response agencies and community organisations and the aim was to agree on information exchange and sharing needs in order to cater to the needs of a potential industrial accident. At the third level, long-term risk reduction planning issues were discussed with local planning organisations also forming part of the stakeholder group. The stakeholder interactions included local workshops, seminars, group meetings and stakeholder education initiatives undertaken in Haldia as also regional and national level programs to involve stakeholders at higher levels.

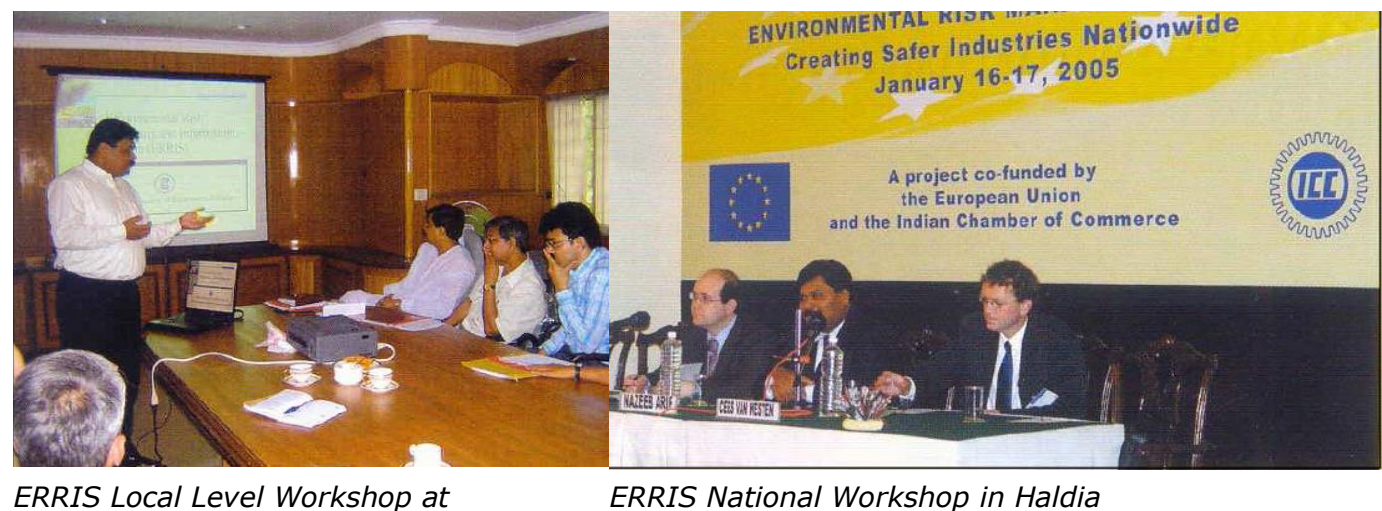

ERRIS Local Level Workshop at

ERRIS National Workshop in Haldia

Durgapur

Photo 4-1: Local and National-level Stakeholder Worksop as a part of the ERRIS project

From these workshops, the information exchange requirements between key stakeholders were identified and they are presented in Table 4-3. 
Table 4-3: Inter - Stakeholder Information Exchange Requirements

\begin{tabular}{ll}
\hline Stakeholders & Type of information requirements \\
\hline Industry to & Information on hazardous storage, properties of \\
Administration, & chemicals, hazard protection measures, changes in \\
Regulators \& & $\begin{array}{l}\text { product mix, raw materials, risk and event scenarios, } \\
\text { potential hazard footprints, accident probabilities, } \\
\text { accidental event and near miss notification }\end{array}$ \\
Industry to Industry & $\begin{array}{l}\text { Information about hazards (which can result in } \\
\text { domino effects), risk protection and mitigation }\end{array}$ \\
& measures, accidental event and near miss \\
notification, response resources and equipment's & Response resources - emergency response \\
Industry, & resources, availability of hospitals / health recovery, \\
Community & Population densities and information on \\
& vulnerabilities around hazardous industries \\
& Planning zones, areas which are hazardous and \\
having building restrictions & \\
& Evacuation routes, stay at home strategies - local \\
& assembling points, safety precautions \\
& Local met conditions - prevalent wind directions \\
Information on Emergency responders
\end{tabular}

In addition to the cross-stakeholder information needs, the workshops also provided the following feedback in terms of risk management information requirements:

- A need for information with geographical context, providing for sufficient detail and accuracy in the digital base map, so as to provide a more effective situation assessment with regard to location of hazard sources, vulnerabilities and population densities, response agencies, escape routes, high-risk zones at an appropriate scale.

- More efficient sharing of data between industry, regulators, administrations and stakeholders, breaking away from the existing compartmental approach to take ownership and maintain data at key points where it is generated.

- A mechanism for maintaining data on hazards, vulnerability, response and planning resources up-to-date, as inaccurate data may lead to faulty decisions.

- Better communication of reasoning which is applied by administration / planning agencies for risk based protection and planning measures in high-risk areas.

\subsubsection{Use Case for Industrial Risk Management}

A use case diagram represents user's interaction with an information system. Such a diagram is able to identify different types of users of a system and show the relationship between the user and the different use cases in which 
the user is involved (Gemino et al., 2009). As a part of the RMIS development process, based on the bottom-up understanding of user information and decision making requirements, a workflow modelling approach has been used to develop use cases for industrial risk management. The use case in Figure 4-3 below delineates a step-wise process for risk management with regard to short (emergency) and long (land use zoning) term planning guided by risk considerations, maps information flows and identifies the possible roles that the risk-actors may be anticipated to play in an industrial risk management situation.

After a risk scenario is identified based on an industry level risk identification and assessment process, the results can be used for, on one hand, emergency planning and response after the calculation of potential consequences through hazard modelling and assessing the elements of risk that be affected. The outputs of this process can then be used by the crisis or emergency manager to prioritise emergency actions like evacuation or shelter-at-place or to optimise movement of emergency vehicles through safer routes. On the other hand, hazard scenarios along with accidental event probabilities can be modelled for calculation of individual risk function based on standardised process set by the regulator and coupled with population vulnerability to spatially portray a measure of social risk as potential loss of lives (PLL). The societal risk distribution along with other planning indices can be used by spatial planners, in collaborating with other stakeholders, to lay down risk guided land use zoning plans. After the risk is monitored at periodic intervals, a feedback loop can be used to improve the process of risk management. 


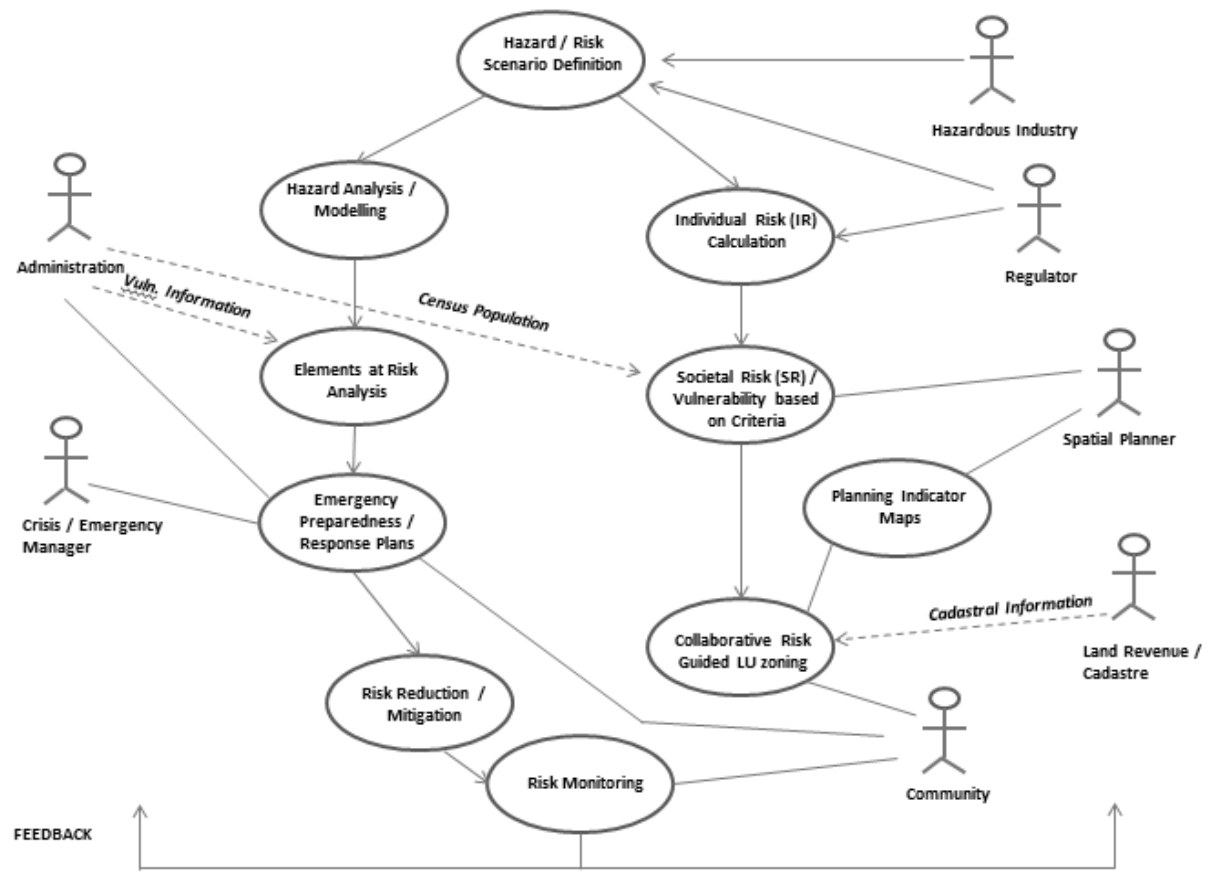

Figure 4-3: Use Case Diagram for Industrial Risk Management

\subsubsection{Data Identification}

To apply an information system approach to the case study area, real world objects representing hazards, elements at risk, other linked locational and attribute data needed to be converted into a form that can be systematically stored and analysed. This section briefly describes specific data requirements.

\section{Hazards Data}

A significant component of industrial risk data comprises data on hazards that originate from fixed hazardous installations, pipelines, infrastructure and services involved in transportation of hazardous chemicals. The non-fixed hazards would include mobile sources like trucks, railway rakes, ships, etc. which are used for transporting hazardous chemicals. The identification and characterisation of the hazards requires the commissioning of a planned exercise in collaboration with the hazardous industries and is considered to be the first step in the risk assessment process. Figure 4-4 shows different aspects of data that would need to be accounted for the hazard identification process. 


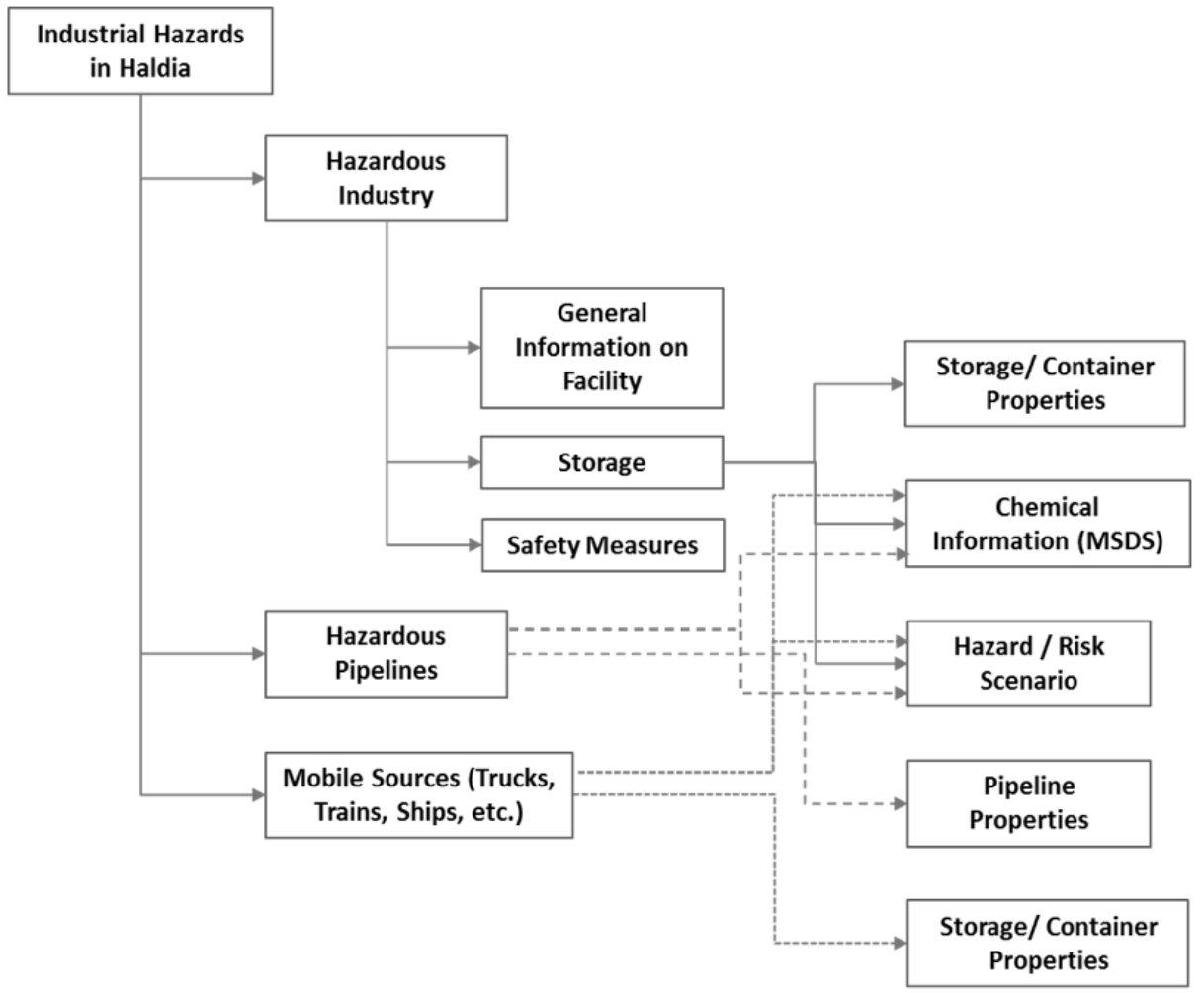

Figure 4-4: Identifying and Characterising Hazards in Haldia

The general information about the facility pertains to understanding geographical extent of the facility, the main process the industry is running, number of employees, the layout, knowing information about the key contacts who need to be in the network of risk related planning, etc. The storage of hazardous chemicals needs to be geo-located accurately so that the origin of a particular hazard can be traced. In addition, the physical characteristics (type of tank, material of construction, thickness, etc.) the condition of storages (under normal temperature and pressure, pressurized, cryogenic, etc.) and the inherent safety considerations that are designed to prevent an accident from happening (leak alarm systems, water curtains, secondary storage, etc.) needs to be documented as they have a crucial bearing on the nature of hazard event that can be triggered from a storage. The hazardous chemicals involved has it physical and chemical properties which significantly influence the degree of damage an accidental release or an event like a fire or explosion involving it may cause. Such information including the physical and chemical properties of the chemical, safety precautions, emergency actions on accidental exposure, etc. are normally available for all hazardous chemicals in a Material Safety Data Sheet (MSDS). 
The other important aspect related to hazard characterisation is the information on the hazard or risk scenario associated with hazardous storage or associated processes (Ale, 2002). A hazard or risk scenario, from the risk assessment point of view, tries to identify all possible deviations that could arise from a hazard source and resulting in an accident (Delvosalle et al., 2006). It should be noted that a single hazard source could possibly contribute to a large number of possible scenarios, small and large and with varying degrees of probability of occurrence. In order to make a risk assessment scenario practical and realistic, a limited number of credible scenarios is generally considered out of all possible risk situations. Based on consistent and agreed upon benchmarks, a shortlisting of such scenarios that can cause offsite consequences to the surrounding community is undertaken and considered as the base for risk assessment. Also, as the hazardous storages contain a much larger volume of chemicals compared to the volume involved in the process, the major credible scenarios have been associated with the storages and not the processes at this time. However, if the exact location of a probable process failure can be identified and release volumes that can get involved in a major accident can be assessed, accidents with a process location as a source of accident can also be accommodated in the hazard assessment exercise.

At the risk identification phase, generally a two phase process is followed for identification of a hazard scenario - first a 'fault tree' scenario leads up to stage where a loss of containment can occur; second, an 'event tree' considers the sequences of events following the loss of containment. These two stages dealing with the possible universe of events that can originate from a hazard source and their relationships are often represented by a 'bow tie' model. Several methodologies for identifying such potential accident scenarios have been formulated by the risk assessment community (Tugnoli et al., 2013). For treatment in the RMIS, our focus has been on the event tree part of the scenario leading up to the identification of a certain number of 'reference scenarios' (Delvosalle et al., 2005). Such scenario identification is undertaken with the certainty that a benchmarked and consistent set of methodologies for identification of major accident scenario (MIMAH) has been utilised as a part of facility level risk assessment process (Fabbri et al., 2009). The RMIS design has to take into account the details of such scenarios, which can then be stored in a risk scenario database for each of the respective storages concerned.

Once an accidental event involving a release of a chemical occurs in a hazardous chemical storage or pipeline, a possible chain of consequences can be triggered and needs to be evaluated based on Event Tree Analysis (ETA) (AIChE/CCPS, 2000; Casal, 2008). The nature of the accident's outcome 
(explosion, fire, toxic release) depends on the conditions of storage, nature of failure that occurs, mitigation and protection measures available at site, location of ignition sources, meteorological conditions, etc. after the release. Once an event involving an accidental release of a chemical occurs, the ETA evaluates the evolution of the event through a logical decision tree connecting all initial events with potential final effects, along with conditions that may result in a particular path in the tree being realised. For effective emergency response measures to be initiated, the potential scenario needs to be realistically assessed based on expert knowledge of industrial risk assessment. Figure 4-5 illustrates an event tree that may involve a release of liquid petroleum gas (LPG) from a pressurized above ground storage tank through a logical sequence of steps from storage - critical event - dangerous phenomena - to effects.

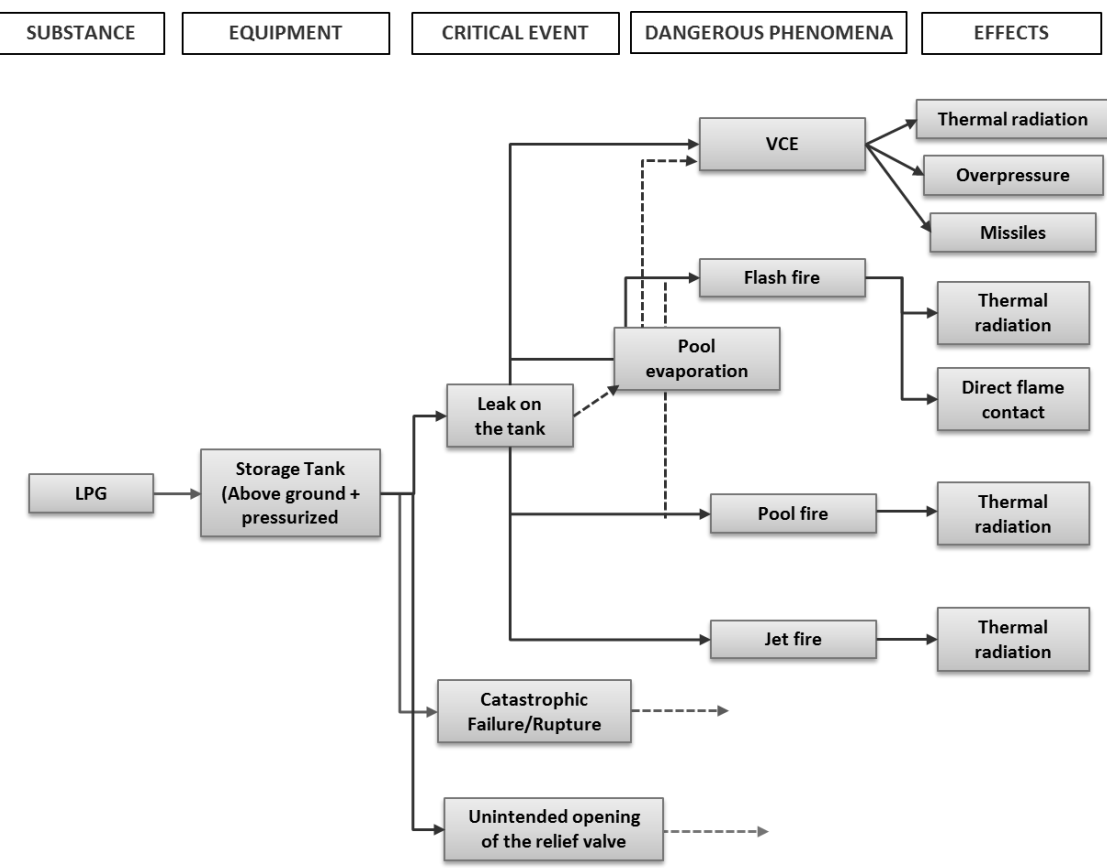

Figure 4-5: Event tree for $L P G$ storage tank releases Adapted from (Christou et al., 2011)

\section{Cadastre \& Buildings}

Long term risk reduction strategies provide considerable focus on limiting or influencing land use around sources of natural or industrial hazards as a risk prevention and mitigation measure (ISDR, 2004). Cadastre information in the form of a parcel level map of an industrial area can play an important role in understanding how certain land uses and the property they characterise may be impacted by industrial accidents. Resultantly, spatial and land use 
planners are increasingly reviewing cadastral information to assess present land uses around hazardous facilities and adapt policies and plans involving zoning and rehabilitation in order to control or reduce risks associated with a particular land use, like a cluster of hazardous industries.

Many countries have adopted multi-purpose land cadastre systems that are centred around a digital cadastre database (DCDB) which are made compatible or integrated with other systems including country level SDIs. The DCDB provides land parcel level information in a referenced spatial framework to multiple user groups. Several well-established data models are used for structuring data in such cadastral information systems that serve several land administration related functions, including spatial planning. In India, digitization and update of existing paper cadastre maps have been initiated through the National Land Records Modernization Program, yet till date there is no country wide cadastral data model that had been formulated leading to a lack of integration of cadastral information with the NSDI (Sengupta, Lemmen, et al., 2015). Because of these shortcomings, the RMIS presently aims to use digital cadastral data made available by the Haldia Planning Authority, which has been organised into a standardised data model that can allow for the spatial planning and land use control functions.

Buildings in hazard prone areas that house population represent an important element-at-risk. The behaviour of buildings when impacted by a particular type of hazard will determine the safety of its inhabitants and as a result it is important to be able to capture data on buildings that will help in assessing the adverse impacts on a building caused by a hazardous event (Blong, 2003). In case of industrial hazards, involving a toxic release, fire or explosion, several aspects of a building would be of relevance, including the type of construction, height of the building, air ventilation characteristics, fire protection mechanisms, etc. Especially in a country like India, where urban areas have wide variability in building types and construction methods from informal hutments to high-rise buildings made of concrete, data on buildings would be crucial for estimating vulnerability of general population and that of sensitive receptors like schools, hospitals and markets. In addition, projection of population inhabiting a building at a particular time of the day is also important to get a likely estimate of population impacted at a time the hazard event occurs (HSE, 2005).

\section{Population}

Distribution of population happens to be one of the key elements-at-risk from a risk assessment point of view as it helps to estimate the damages in potential terms of loss of life or injuries, the most significant vulnerability or loss that can be caused by a risk event (Van Westen, 2013). Considering industrial risk assessment using quantitative methods, the estimation of 
population data is key to the calculation of societal risk caused by hazardous industries in an area of concern and which then guides decisions on risk reduction and land use planning (HSE, 2005). In the short-term planning context, emergency preparedness and response also requires additional information of population present at vulnerable receptors (e.g. schools, hospitals and markets). In addition to the static component representing the number of inhabitants in an area, the dynamic component representing the space and time distribution of population is also important to arrive at correct risk estimates (Bonvicini et al., 2012).

Several methods are used for estimating spatial distribution of population based on the scale at which the risk assessments are undertaken. At larger scales, Census survey data collected by governments and represented in the form of Census tract population is sufficient for estimation of vulnerability (FEMA, 2004), but analysis at lower scale and involving a densely populated urban area needs additional methods that can disaggregate population data to higher resolution than Census tract units (Su et al., 2010). Such methods utilise techniques like areal interpolation, geographical weighted regression (GWR) and geo-statistical modelling (Flowerdew et al., 1992; Fotheringham et al., 1998). Remote sensed data and especially high resolution imagery also supports the mapping of land uses at high level, going up to the mapping of building footprints, which when coupled with Census data and various extrapolation methods can provide a good estimate of population at a high level (Rhind, 1991). Databases like LandScan and GPW3 apply dasymetric modelling techniques using Census tract information, remote sensed data and other available information to disaggregate Census tract data into grids varying from $5 \mathrm{~km}$ to $1 \mathrm{~km}$ resolution are now available for the entire world (Bhaduri et al., 2007; SEDAC, 2005).

For the specific purpose of industrial risk information system, population data have been estimated to a resolution of $100 \times 100 \mathrm{~m}$ grid that is commensurate with the requirement for calculation of societal risks and the understanding of population vulnerability for emergency preparedness and response (HSE, 2005). For this purpose, an interpolation method that combines census tract data and land use data from very high-resolution (VHR) imagery, and validated by ground surveys have been adopted for the Haldia urban area. The methodology used is illustrated in Figure 4-6. 


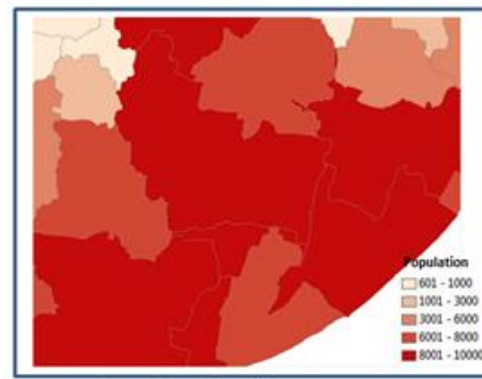

Census Tract Population

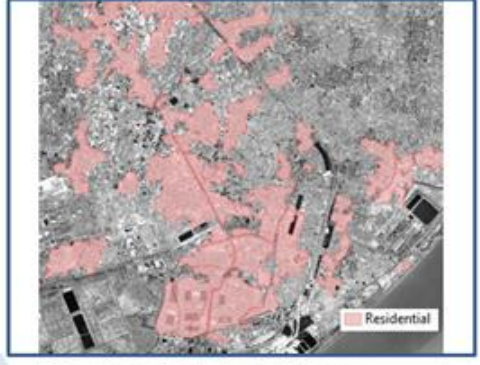

Habitated areas identified from satellite imagery

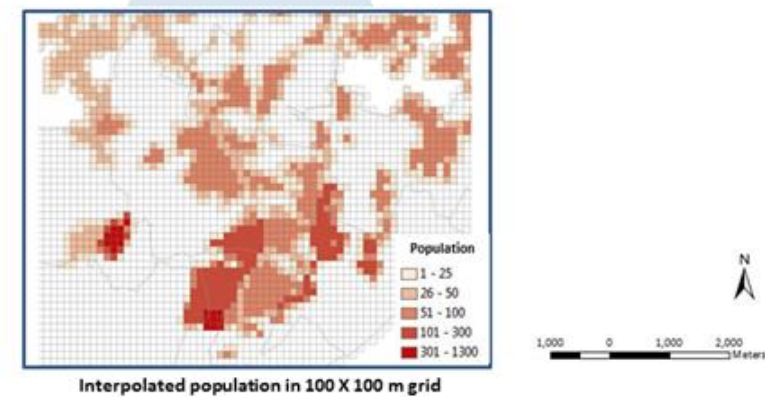

Figure 4-6: Interpolated population data in $100 \times 100 \mathrm{~m}$ Grid Source: (Sengupta, Lemmen, et al., 2015)

\section{Transportation}

Transportation planning has a strong interface with disaster management, in context of risks associated with chemical accidents. When an accidental event occurs, transportation corridors like roads can play and an important role as evacuation routes for high population areas while providing responders access to the site to tackle the adverse consequences caused by the accident. To enable such planning, information on capacity of transport corridors and their spatial disposition and interlinkages is required (Cova et al., 1997; Georgiadou et al., 2010). On the other side, transportation corridors themselves be a sources of hazard affecting vulnerable population in the vicinity or be affected by the accident causing a hindrance to access and prevent evacuation of vulnerable communities. This aspect is especially relevant from the context of industrial accidents and necessitating development of techniques that focus on analysing risks involved in transportation of hazardous chemicals by road, rail or pipelines (Bubbico et al., 2004; Chakrabarti et al., 2013; Das et al., 2012; Fabiano et al., 2002).

To cater to the nature of demands, significant research has been undertaken in capturing transportation related data and transportation data models like the ESRI highway model captures geometry and route, details on infrastructure (width, build quality, intersections), traffic load, accident prone 
stretches, etc. (ESRI). This information is generally used for modelling and analysis to improve the efficiency of transportation infrastructure and networks. A similar data model has been conceptualised for RMIS so that vital transportation infrastructure related data can be captured which can then contribute vital information for risk management, enabling emergency planners to undertake a range of analysis like optimal routing of response vehicles or streamlining an evacuation plan for a densely populated urban area.

\section{Sensor Data}

Real time data made available by sensors can play a crucial role in the emergency response phase of risk management (Vescoukis et al., 2012). Such information include meteorological data like wind speed and direction that can influence the diffusion and spread of a toxic plume or real time video feed from an Unmanned Aerial Vehicle (UAV) stationed above the disaster site to provide better situational awareness to emergency coordinators and response personnel and thereby assisting them to effectively coordinate personnel and resources. Considerable research is being undertaken to look at opportunities involving integration of sensors to provide more real situational analysis from area affected by a risk event or a disaster thereby providing better manageability. For example, in Vietnam real time precipitation data is being integrated from remote rain gauges as a precursor for predicting and monitoring floods and landslides (Brovelli et al., 2012) and in the Netherlands, real time UAV video is being proposed for use in fire emergency management (Persie et al., 2012).

With the proliferation of relatively affordable electronic sensors, wireless sensor networks (WSNs) comprising large number of sensor nodes, interacting with the environment and communicating with each other can be considered as a feasible method to identify spatial and temporal patterns of physical phenomena like the spread and movement of a toxic plume originating from an accident site (Koutsoukos et al., 2007; Shen et al., 2008). Presently, the design, optimization and deployment of such complex sensor networks have to overcome challenges like operating across heterogeneous communication infrastructures and providing packaged data to accepted standards to maintain the functionality of services (Ibbotson et al., 2010; Liu et al., 2005). The conceptualisation of the IRM-SDI and the RMIS considers the use of OGC compliant web services that would share information from real time heterogeneous sensors over the internet through open and platform independent Application Program Interfaces (APIs). However, till the time such services are available, data feed to the RMIS will be enabled through setting up of local level sensor networks that can provide first level of information on meteorology, video feeds etc. channelized through the local emergency management centre. 


\subsubsection{Data Model for Industrial Risk Management}

The heterogeneous data to be stored in the Risk SDI or in the other SDIs to be shared through the RMIS platform are to be typically stored in spatially enabled object-relational databases. Risk management, especially those related to emergency management, requires information to flow efficiently from an information system platform and interoperability between data sources which may be housed with several data providers or agencies. Such interoperability can be ensured through the adoption of consistent data standards that are capable of logically relating data originating from these heterogeneous sources (Chen et al., 2008). Setting up data models and application specific schemas that define the data stored in underlying databases is also key to the efficient functioning of a SDI so that the data can be exchanged through standardised web services like the Web Feature Service (WFS) (Scholten et al., 2008). At present no such comprehensive data models for risk management has been designed in India.

In order to develop a clear and logical understanding of the data, and proposed relationships, a spatial schema based abstract information model may be written using the Unified Modelling Language (UML). Due to the absence of standardised data models for industrial risk in the Indian NSDI, it is postulated that the RMIS data model will be built with common aspects from standard application specific data models already defined by government agencies and industry organisations, which are available for use by specific geospatial disciplines like cadastre, buildings and transportation. It is intended that the RMIS data model should be available as an application schema of Geographic Mark-up Language (GML). It could then be published through the RMIS geo-portal and made available to others who would want to share a common pool of data in the broader frame of an SDI, after making necessary changes, perhaps by removing some optional attributes that may not be applicable to their specific uses. To ensure interoperability of data originating from multiple and distributed databases, there has to be clear reflection of various feature attributes and topological relations through underlying application schemas, so that semantic conflicts in interpreting such data can be avoided. In doing so, appropriate semantic annotations have to be arranged in order for correct meaning to be clarified to the user (Janowicz et al., 2010). Figure 4-7 shows a UML class diagram representing the Risk Management Information System data model. The data model comprises critical entities that facilitate exchange of information between different stakeholders during risk related decision making and when accessed through an information portal like RMIS will provide necessary support to planners for risk guided decision-making. The relationship between different entities within the class diagram has been further defined using stereotypes, depicted as keywords encased by two-angle brackets. 
In the model, class Industry contains information on spatial location of an industry, it's processes, emergency contact numbers and name of the incident manager who could be contacted during an emergency. The information is important to notify and communicate with the industry during an emergency and while response operations are being conducted. The stereotype <<belongsto>> connects Storage and Pipeline classes with Industry. An industry is expected to contain several storages as represented through cardinality of the association. Thus, the association facilitates capturing the inventory of hazardous chemicals stored by an industry. Storage class represents data related to spatial location, type, capacity, wall thickness, operating parameters and the chemical it stores. Pipeline class contains information on the spatial alignment, wall thickness, material, flow rate and the chemical it transports. Depending on the hazard source, both sets of information are critical to model a risk scenario. In addition, the class Mobile Source contains information on vehicles that carry hazardous chemicals. Typically, such information includes spatial location of the vehicle which can be captured through an on-board GPS tracking device, about chemical being transported, storage capacity and carriage parameters. The spatial location of a mobile source would help to identify nearby vulnerabilities should it be involved in a hazardous incident.

The class Chemical contains description of the chemical product involved in a hazard scenario. The class stores chemical name, flammability, flash point, density, molecular weight, lower and upper explosive limits, and IDLH values - information required to model a chemical incident and determine its extent. Stereotypes <<stores $>>$, <<transports >> define the relationship between Storage, Mobile Source, Pipeline classes respectively with the Chemical class. The class RiskScenario lists all possible hazard scenarios that may be associated with a particular storage or pipeline and the chemical it contains or transfers. The associations <<leadsto>> connect Storage and Pipeline classes with the RiskScenario class. The class RiskScenario lists all possible hazard scenarios that may be associated with a particular fixed storage, mobile vehicle or pipeline and the chemical it contains or transfers. Stereotype <<involves>> connects Storage and Pipeline classes with the Chemical class. The class Incident is associated with the class RiskScenario and Meteorology, which provides information on different atmospheric parameters required to model a hazardous incident. An emergency coordinator, based on a reported incident, can select a particular scenario from the list of available scenarios and subsequently model the hazard.

The class Parcel contains information about the smallest unit of land that is related to some of the key entities involved or affected during an emergency e.g. Industry and Building. The Parcel class also contains data on land use and land area that serve as critical inputs for risk based land use planning 
and defining zoning restrictions for future developments. The $<<$ contains $>>$ stereotype connects Building and Industry classes to the Parcel class. While there could be several buildings on a parcel, typically there is a one to one correspondence between a parcel and an industry - this is reflected through the cardinality of the associations. A hazard incident could have the potential to damage a building and the population residing within it. Therefore, the Building class contains information on the spatial location of the building, construction type, elevation and total number of inhabitants classified into six groups at four-hour intervals covering 24-hours population data. Depending on time of the day, the hazard incident occurs, the four-hour interval population statistics is important to make a near realistic estimate of the affected population in buildings. In addition, class Population captures spatial distribution of clustered population as maintained by the Census department. The information is useful while modelling a gaseous release spread over a large area and estimate the total population that may be affected or while conducting land use planning exercises for siting new developments. Class Road contains information for determining the routes that may be used to mobilize emergency response or identifying the roads that may be affected by a hazardous incident. Stereotype <<affects>> connect Population and Road classes with the Footprint class that models the spatial cover of a chemical accident.

Class Occupant is a super-type or a generalized class that contains information about name of the occupant, contact details, occupant type and spatial location. Classes Responder, Commercial, School and Hospital are derived from the occupant super-type. The derived classes have their own specialized attributes that are important for emergency management and response e.g. class Hospital contains information about total number of doctors and nurses, availability of trauma unit and blood bank; class School contains information about total students and staff, opening and closing times, weekly holidays, etc. Considering the occurrence time and day of a hazardous incident, such information will help emergency managers to analyse whether response teams needed to evacuate affected population from a school or whether specialized trauma units from a particular hospital need to be mobilized at an incident site given the nature and intensity of a hazard. 


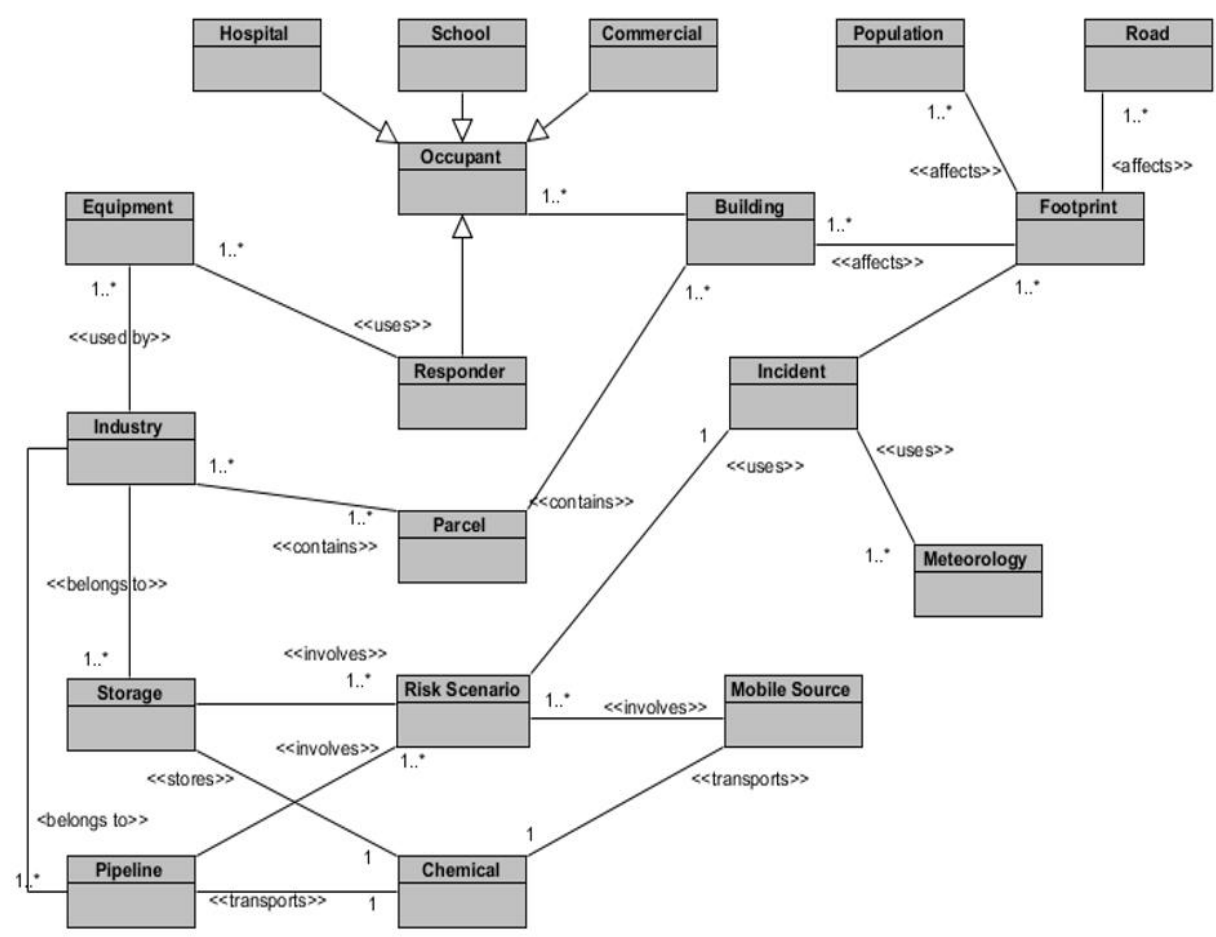

Figure 4-7: Data Model for Industrial Risk Management

\subsection{Design and Implementation of the RMIS}

\subsubsection{RMIS Database and Data Services}

The RMIS has been designed as a combination of the native database residing within a context-aware Technological Hazard SDI and shared data services expected to be served by other context-aware SDIs and specialised data feeds. Figure 4-7 shows the overall information framework for RMIS. The native database for RMIS comprises of the industry, storage and associated databases. The non-spatial data for the industry and storage databases has been populated based on data provided by the industries, as a part of a voluntary risk reporting initiative under the ERRIS project and subsequently verified through a facility level safety audit (Bandyopadhyay et al., 2013). Additional spatial information like exact location of hazardous storages has been obtained by analysing VHR imagery and validated through ground surveys. The RMIS native database, which is shown diagrammatically in Figure 4-8, comprises of the following:

- Facility Identification: details of the subject MAH facility, so as not to be confused with any other facility including data on name and physical location address; names, position and phone number of key personnel 
responsible for risk and emergency management, site and vicinity maps, etc.

Hazard Identification: an inventory, identifying all the hazardous chemicals used or stored by the facility and their MSDS. For each product or chemical listed, the storage location and nature/type of storage indicated, as well as the anticipated average and maximum quantities.

- Facility Risk Mitigation \& Response Resources: Safeguards for risk reduction, equipment and resources for on-site emergency response, plan identifying the industry's emergency equipment and resources for responding to a chemical release, spill or explosion quantity, location of emergency protective equipment available from the facility.

- Chemical database: Storing data on specific hazardous chemicals including chemical identification, physical and chemical properties, hazards data, preventive and mitigation actions. The database follows the template of the Chemical Safety Datasheet provided in the MSIHC Rules and additional parameters as is required for effects modelling.

- Risk Scenario Database: to store details of potential accident scenarios involving storage of hazardous material, which has been identified and evaluated as a part of industry specific risk assessment exercise. This will include the description of potential accident scenario and specific information that would be required to undertake hazard or risk modelling.

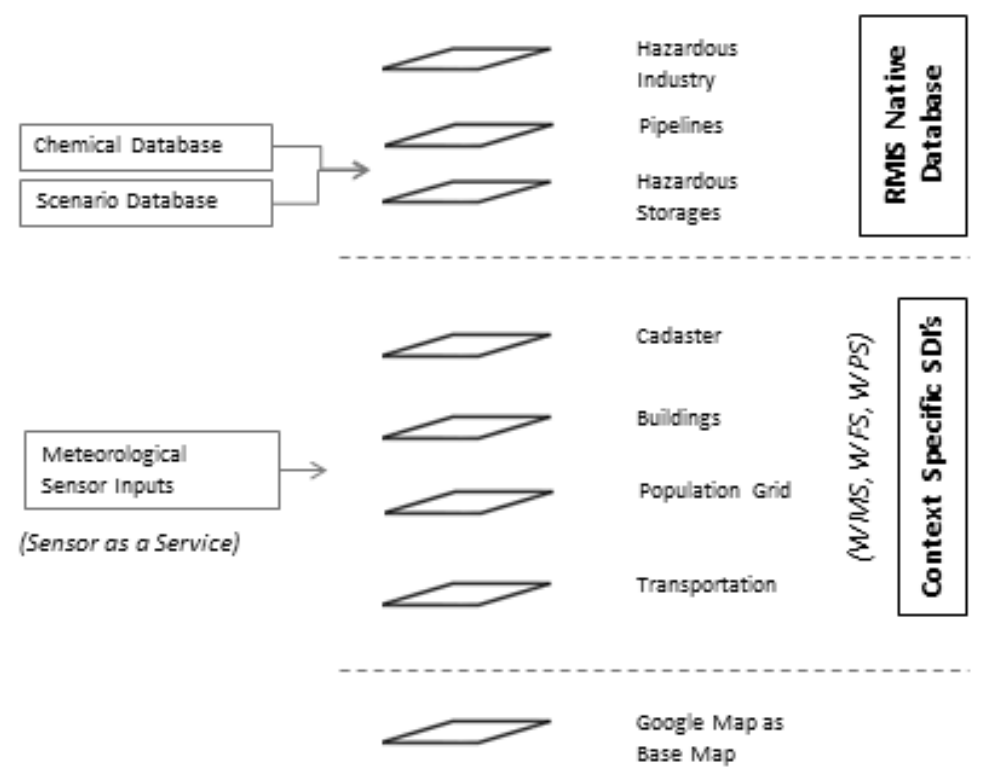

Figure 4-8: RMIS Framework - Data and Services 
In addition to the native database, the RMIS would require information on several other aspects as identified in the concept development stage to serve informational and decision support needs of users. It is expected that such data would be made available as per the RMIS data content requirement through web data services that conform to OGC data specifications. At this time, for the purposes of demonstrating the system, these datasets have also been prepared and made available through native databases or through other open data specifications and services. Below a brief description is given of the services and the data they provide to the RMIS:

- Cadastre: Spatial data on land parcels, land use type, land ownership;

- Buildings: Time averaged population, building type, other vulnerability related details;

- Population Grid: Interpolated population in a 100 X $100 \mathrm{~m}$ grid, appropriate in terms of detail for QRA calculations;

- Transportation: Road and railways alignments and nodes, transportation bottlenecks, time wise traffic density data, accident prone stretches;

- Meteorology: Near real time (every 5 mins) data on wind speed, wind direction, temperature, solar insolation from a meteorological station stationed at site.

Additionally, in order to have a common base map for the application, that users would be familiar to, integration with digital earth based map interface has been implemented. This would enable the RMIS native layers and those called from other distributed map services to be overlaid on a Google map imagery, OpenStreetMap or any other Hybrid map layer. The RMIS has presently implemented this aspect by invoking the Google Map API through a wrapper on OpenLayers-3 making use of appropriate style, declarations and initializing code.

\subsubsection{System Architecture}

The RMIS has been designed as a distributed web enabled decision support system (web-DSS) that incorporates tiered service oriented architecture principles (Vescoukis et al., 2012; Zhang et al., 2007). The design considerations ensure that the system services are highly interoperable with spatial, statistical and sensor based data from heterogeneous sources/data custodians irrespective of the modes or languages used to implement such datasets. The system is capable of interacting with large amounts of geospatial data (e.g. cadastre database), interfacing with real-time sensor network (e.g. meteorological station datasets), incorporating domain specific knowledge through analytical models and tools (e.g. consequence and risk modelling algorithms) and finally presenting information in a way that can be effectively used by decision makers in emergency management or as inputs for risk based land use planning. 
The web-DSS spatial components are based on a collection of OGC compliant web services that communicate with each other for data sharing, geoprocessing and geo-spatial representation over the internet. Geo-spatial presentation typically includes visual overlays of geographic information as per application scenario e.g. simulation of a consequence analysis model as a hazard footprint showing spatial extent of the damage or displaying road segments affected by a particular hazard footprint using geo-processing techniques like spatial intersection. The system specifically conforms to OGC WMS and WFS standard specifications. WMS provides web clients with a standard interface to request applications having the capability to deliver geo-referenced raster map images using data from a spatial database. WFS provide the ability to host or access geographical feature data with geometry and attributes over the internet by sending requests encoded in GML from the web client. The requests are then passed onto the backend geo-spatial database thus load-balancing intensive geo-processing activities on to the server. The requests are translated into SQL to query the spatial database and the results are translated back into GML before they are returned to the client. In addition, WFS also supports filters that allow applications to perform spatial analysis on the data.

The web-DSS utilizes WMS to fetch maps for visualization purposes and WFS services to query and interact with geographic data through custom HTTP requests sent from its web interface. The RMIS architecture implements WMS and WFS specifications using ArcGIS geospatial platform services. However, it is possible to implement the design concepts using any OGC compliant webGIS provider with necessary modifications specific to the implementation platform. The RMIS three-layer architecture shown in Figure 4-9 shows the interactions between data, external web services, related analysis and modelling tools that together support the decision making process. The architecture provides a tiered view of the RMIS and isolates the complexities of data management, analytical processes and application interactions of a web-DSS in their respective tiers.

The Data Layer contains spatial and relational datasets on hazardous facilities, tank storages, chemicals, pipelines, vulnerable receptors, responders and equipment. The layer also stores modelling outputs to support the quantitative risk assessment and based planning functions. The layer exposes a data management interface that provides filtered access to the data repository according to requests received from client processes. The data management interface communicates transparently with the ArcGIS platform services using specially structured HttpService requests for transferring spatial data. The ArcGIS server platform implements services that are specifically used by the RMIS e.g. WFS, WMS and WCS for spatial data management and analysis. 
Domain specific knowledge on risk management and planning is consolidated in the Application Layer through statistical and analytical tools that add value to the raw spatial and relational data received from the data layer. The layer also contains a Web Service Management function that collaborates with external web services published by different stakeholders and fetches data that is critical to risk management functions e.g. related to population, meteorology, cadastre, roads and the like. The Web Service Management function is dependent on requests received from the analytical tools in this layer to select the appropriate web service from a web services directory that is published internally within the system. The function implements REST (Representational State Transfer) architecture that allows it to communicate with heterogeneous web services irrespective of their implementation platform or data types that they expose. The communication with web services are initiated through standard HTTP interfaces and invoked using a WSDL (Web Services Description Language) document. WSDL describes a web service in terms of how the service can be called, what parameters it expects, and what data structures it returns.

The Application Layer also extends to a Modelling Service that specifically implements domain specific modelling algorithms e.g. hazard modelling, consequence modelling, scenario simulation, etc. and presents the data in the form of spatial overlays in the web client supported by model run outputs. The Web Service Management function communicates with the Modelling Service to provide real-time data related to meteorology and population from the external web services.

Presentation Layer contains the web-enabled interfaces of RMIS that allow decision makers to interact with the web-DSS. It manages information from the Data and Application Layers and presents the same for decision support. The layer interface implements several technologies starting with plain HTML pages that incorporate OpenLayers JavaScript APIs to consume spatial data and maps from Google and OpenStreetMap, render custom maps generated by ArcGIS map engine, display GML overlays of model runs using XSLT to incorporating custom functions that communicate directly with the underlying layers to process information. 


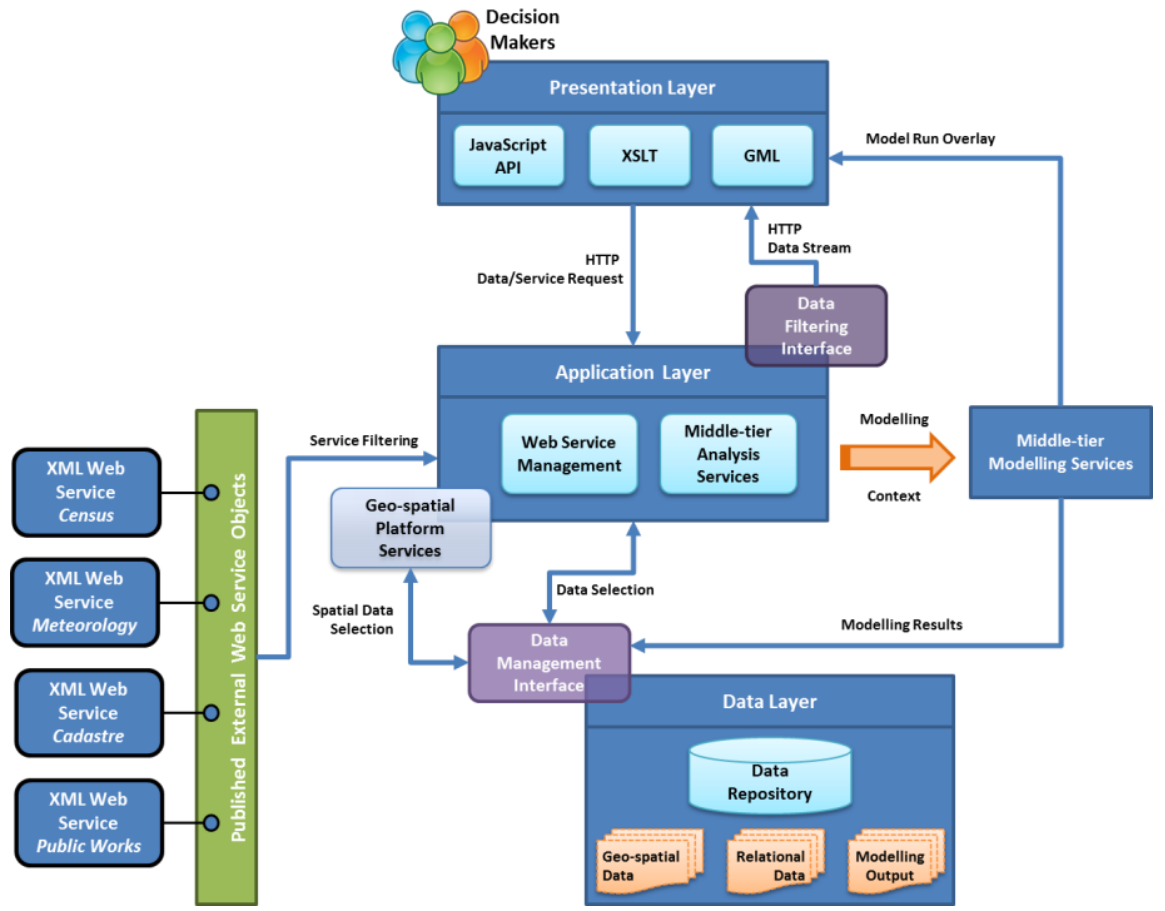

Figure 4-9: System Architecture for RMIS

\subsection{Demonstration of Prototype RMIS}

The user interfaces of the RMIS geo-portal provides several options, including the map-based interface where a user is presented with several choices for viewing and retrieving information through its intuitive interface. Other options can lead to associated databases like the MSDS database or to interfaces to update data for users with privileges to change data. In addition, if accorded access rights, they can use value added decision or planning support functions through the same interface, which are discussed in later Chapters. The following section discusses the information functions in detail.

\subsubsection{Querying Information and Maps}

The user of RMIS has the choice of making queries for finding industry hazard related information through a number of routes. The user can use the map interface to query for information related to a particular spatial feature using point-and-click functionality - industry, storage, elements at risk and be presented with the first level for information on the spatial feature. In a sequential manner, it would be possible for the user to view other associated information through hyperlinks provided to other parts of the database. For example, a point-and-click on an industry would bring up details from the 
industry database, and will provide a link to data on individual storages housed within the industry and further to details on the stored chemicals. A second choice for querying information is through the query wizard interface. Using this interface, which opens up as a pop-up-wizard, the user can make relational queries based on selection of pre-set parameters. For example, a typical query to assess the fire risk situation of Haldia by the regulators can be to identify and show all industry having storages of inflammable chemicals, more than 10,000 MT. The query would be processed by the search engine through both the spatial and non-spatial databases and the results would be presented to the user both in the map as highlighted industries and also through a pop-up window providing detailed information about the industries matching the query. The outcome of running this query is shown in the Figure 4-10.

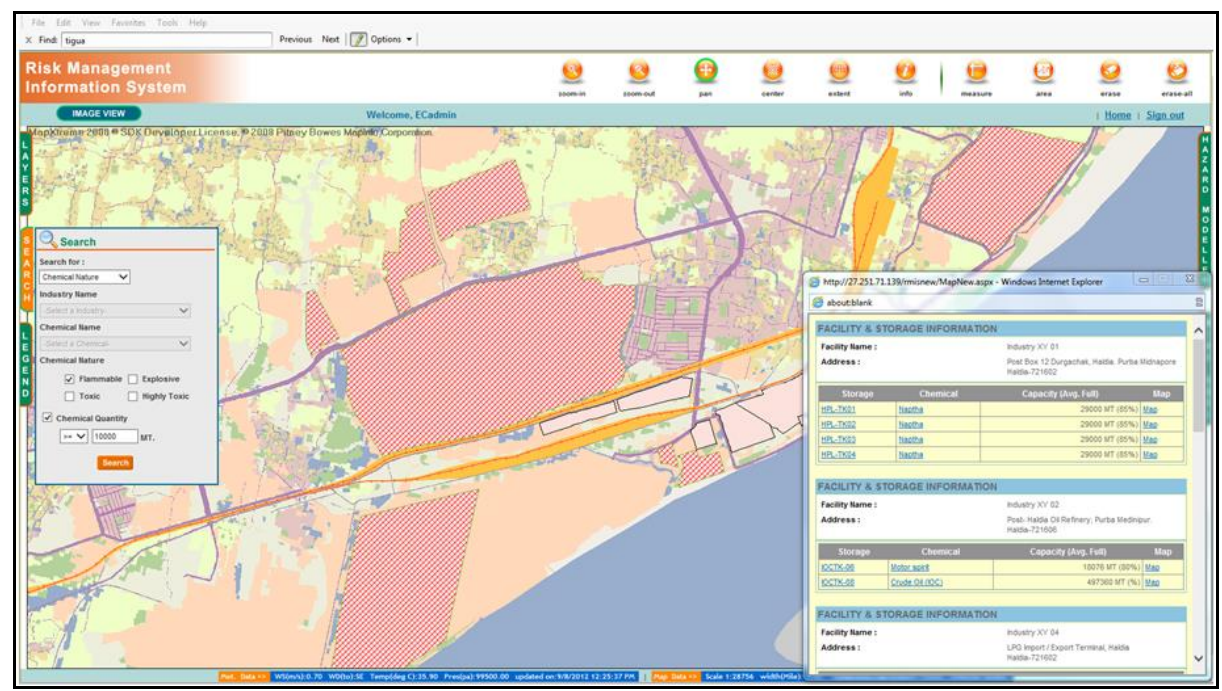

Figure 4-10: Outcome of a Spatial Query to show and identify all industry having storages of inflammable chemicals, more than 10,000 MT

In a similar manner, it would also be possible for users to estimate the potential exposure of population to a hazard by running a query using spatial association as is shown in Figure 4-11. The exposure assessment tool provides the option of creating an area in the form of a circle, rectangle or a bounded polygon in order to query the population grid map and extract information on the probable population that may be present under the footprint. The spatial query would open a pop-up window providing additional information about vulnerable receptors like schools, hospitals, old age homes, etc. at the building level. At the second level, a query can provide building vulnerability related information and a time-population matrix that would show how many students are expected to be present in the school building at a particular time of the day. 


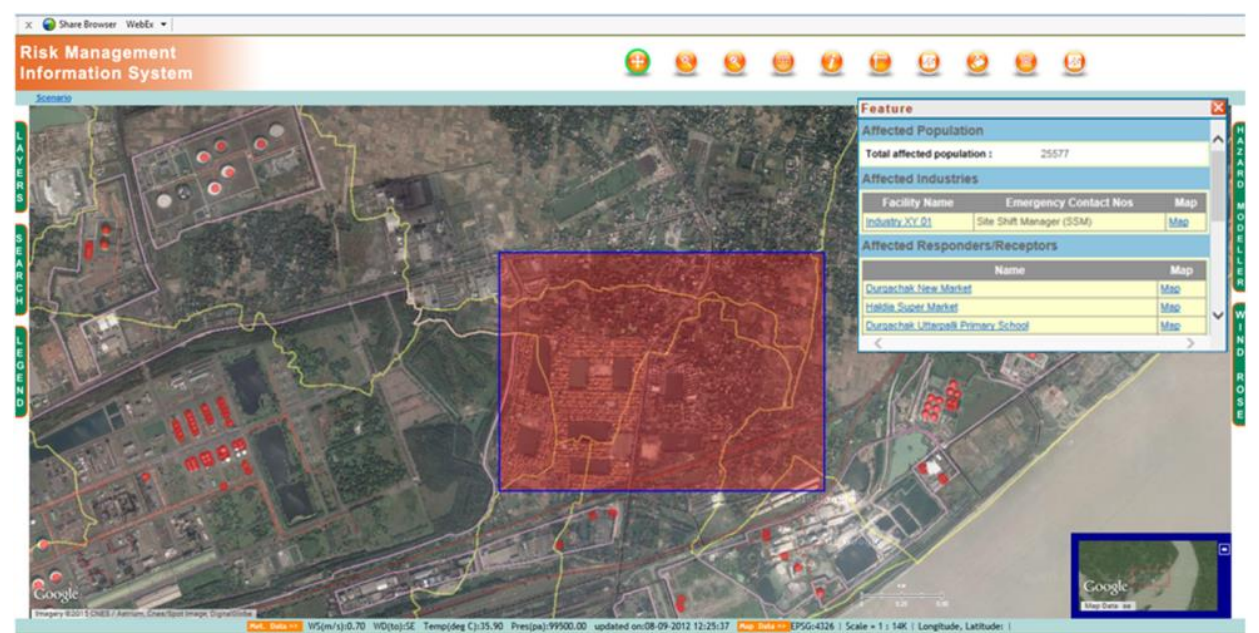

Figure 4-11: Mapping Exposure using Spatial Query

\subsubsection{Adding, Viewing and Updating Information}

Once the initial inventory of industry information and hazardous storages are undertaken and stored in the RDBMS, the RMIS can be used as a platform for storing information on risk scenarios that can potentially lead to major accidents. The information for such risk scenarios would be the outcome of MAH facility specific risk assessment exercise involving HAZOP, HAZAN, bowtie analysis, fault tree or other chemical risk identification and analysis methods commonly used by industry (Delvosalle et al., 2006). Such a risk scenario database would include information on the industry, storage and chemical stored, potential hazard scenarios, amount of hazardous chemical that may be involved, probit and emergency exposure end-points. Having a database with a common information set, which can be accessed by industry based on secure access would provide the opportunity to risk regulators to build uniformity in the way facility specific risk scenario information is made available to risk actors. At the same time, it will enable the use of a consistent set of modelling tools for further calculation of consequences and risk in the form of Individual or Societal risk, so that the risk assessment process can be standardised at the country or state level. Figure 4-12 shows the interface which can be used by risk actors to find information risk scenarios in the Haldia industrial area. 


List of Scenarios
\begin{tabular}{|c|c|c|c|c|c|c|}
\hline $\begin{array}{c}\text { Scenario } \\
\text { Name }\end{array}$ & Industry & Storage & Chemical Name & Total Amount (in MT) & $\begin{array}{c}\text { Amount Involved (in } \\
\text { MT) }\end{array}$ & Action \\
\hline Scenario001 & Industry XY 01 & HPL-SP07 & Butene & 1880 & 800.00 & Edit Scenario \\
\hline$\underline{\text { Scenario001 }}$ & Industry XY 03 & SCTK01 & Ammonia & 10000 & 400.00 & $\underline{\underline{E d i t ~ S c e n a r i o ~}}$ \\
\hline$\underline{\text { Scenario001 }}$ & Industry XY 04 & IOC Petronas-TK01 & LPG & 16000 & 2500.00 & Edit Scenario \\
\hline$\underline{\text { Scenario001 }}$ & Industry XY 13 & HPCL-T001 & Hi Speed Diesel & 6375 & 3000.00 & Edit Scenario \\
\hline
\end{tabular}

Add New Scenario

Figure 4-12: Interface for Risk Scenario Database

In order to ensure that data in the relational database remains current and valid, a provision for online update of attribute data related to industry, receptors and response agencies can be provided through a secure data access and editing mechanism built into RMIS. This was an important requirement conveyed by the risk actors in order to keep data up to date. The Data Update Module of RMIS provides access users are authorised by the system administrator to the data for making changes or modifications online. It is important to note that once the edited changes are saved online in the RMIS database, the updated information is immediately displayed for a new user querying for such information. Trace of data changes and under whose login it has been carried out are maintained in the system records. For example, if an industry user wants to modify or add information on new safeguards which have been installed, it can be undertaken through the interface shown in Figure 4-13. In addition, it is possible to add spatial data on storages and new buildings in point form. In such cases, the exact geographic location of the new feature has to be provided in the form of geocoordinates in the database.

The RMIS industry database can also function as a document management system. Industry specific regulatory reports, permitting and approval information in the form of pdf documents can be incorporated and can be made available to selected stakeholders based on appropriate access restrictions. This feature can facilitate coordination and information sharing between multiple competent regulatory agencies that are responsible for monitoring of compliance to risk regulations 


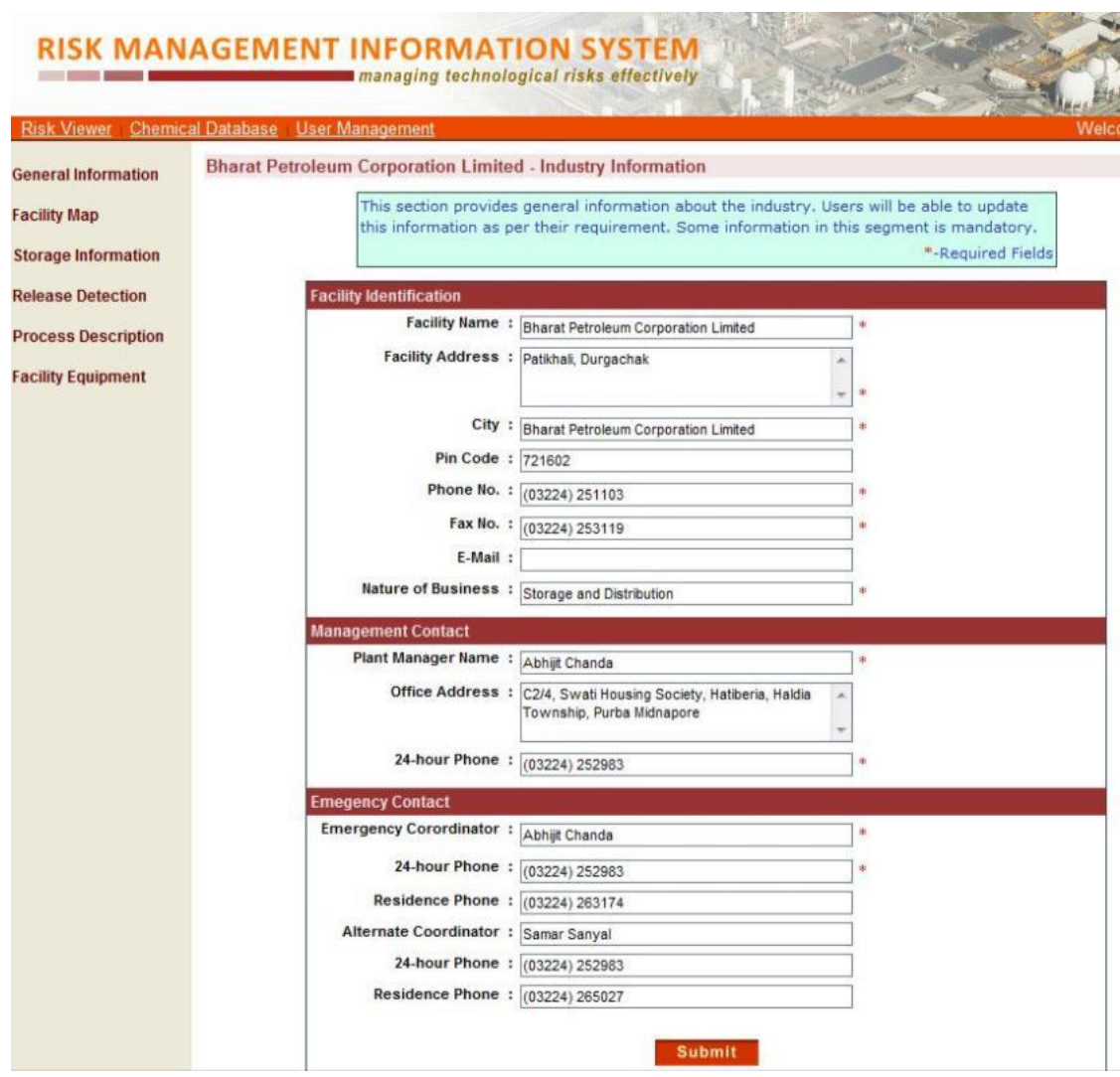

Figure 4-13: RMIS Data Updating Interface

\subsection{Discussion}

Since the early days of SDI conceptualisation and research (Rajabifard et al., 2002; Williamson et al., 2003), disaster risk management has been considered to be a domain where the ability of SDI's to integrate data from multiple sources could assist in effective management, contribute to building better preparedness or even to prevent disaster risk situations from occurring (Mansourian et al., 2006; Molina et al., 2011). At the same time, experience in World Trade Centre, Sendai earthquake and the Fukushima Nuclear disaster has shown that countries with well-developed SDIs have also found it difficult to leverage the heterogeneous information requirements of disasters involving the dependencies of hazard, vulnerability and risk. Characterised by 'right data at the right time' concept, availability of quick and relevant information is crucial to build necessary coordination between different agencies involved in disaster risk management and assist them to take informed decisions. Several research initiatives are being undertaken that makes an effort to integrate the overall SDI infrastructure while adopting and adjusting to information needs of a particular type of disaster. Such 
initiatives include building risk focused and context aware SDIs, embedding specific knowledge bases into existing SDIs or developing specific applications as a shell that can process specific tasks and questions thereby improving their ability to serve information specific to a risk situation efficiently (Annoni et al., 2005; K"ohler et al., 2006; Scholten et al., 2008; Zlatanova et al., 2012). The RMIS tries to capture these research outcomes in it overall conceptualisation, with a provision to link up with the Indian NSDI and making it to function in conjunction with a native database for specific industrial hazard and vulnerability related information.

Other rapid progress in disaster risk information involve convergence in technologies in the field of ICT and the ability to integrate data originating from multiple sources including data sensors, interoperable GRID computing tools that allow dispersed computing resources to be accessed over the internet and 'crowd sourced' spatial data uploaded by volunteers for informing risk and disaster planning (Drummond, 2008; Goodchild, 2011; Kiehle et al., 2009; Persie et al., 2012). The future success of RMIS would be influenced significantly by its ability to flexibly adapt to and integrate these new and converging technologies into its fold. These may include chemical sensors to detect chemical leaks from storages thereby initiating emergency response alerts or UAV based video feeds that relay an actual aerial picture on the development of a risk scenario and the success of response activities to emergency managers in the control room.

The acceptance of RMIS as an information system tool would also be significantly enhanced if it can provide the foundation for decision and planning support for specific activities like emergency management or land use suitability analysis, problems which risk actors currently find difficult to solve at present. Fortunately, this has been one of the stated objectives of the RMIS since the time it was conceived as a component of the ERRIS project. Additionally, recent research is increasingly shifting decision and planning support systems to combine interoperable components from multiple and distributed sources across the internet and provide application specific solutions for a particular domain, accessible to a large number of decision makers online (Balram et al., 2009; Bhargava et al., 2007; Sugumaran et al., 2007). These developments are in consonance with the DSS/PSS components planned for industrial risk management in India as a part of the RMIS platform.

From the point of view of industrial risk assessment practice in India, the RMIS provides several opportunities to be explored along with a clear roadmap to improve regulatory compliance and strengthen risk communication to stakeholders. First, if adopted by competent regulatory authorities and MAH industries, the RMIS would provide a framework 
resulting in a consistent set of information to be collected as a part of risk identification and assessment process based on provisions laid down through regulations. Until now, this has been a critical issue affecting the ability of regulators and emergency preparedness and response teams to process information pertaining to hazardous storages, hazardous chemicals, risk scenarios and work out potential consequences of accidents or derive an understanding of the spatial disposition of risk in industrial clusters. Second, in the absence of standardisation for models, industry specific and cluster level hazard analysis studies have shown considerable variability in outcomes. The application of such non-standardised approaches to risk estimation has led to difficulties in the delineation of clearly defined and consistent risk levels and acceptance criteria that could be used for obtaining a cumulating picture of risk prevailing in industrial areas (GoI:NDMA, 2007). In contrast, several countries like the UK, US and the Netherlands have benefited through the setting of uniform information requirements leading to the application of standardised procedures and models for risk calculation and evaluation which has then been utilised for guiding risk policy and procedures with respect to industrial hazards (Basta et al., 2007; Christou et al., 2011; Pasman et al., 2014). The RMIS, which would be available online to risk actors and provide scope for updating of industry specific hazard data, could be used as the central repository of managing industrial risk related information. At the same time, it can be used as a medium for improving risk communication and awareness amongst stakeholders through easily accessible and intuitive visualization and information query interfaces. 


\section{Chapter 5 - Emergency DSS to Aid Management of Industrial Accidents}

This Chapter discusses the design and development of a web-based spatial decision support system for industrial emergency preparedness and response.

\subsection{Introduction}

Due to significant improvements in risk and safety science over the last few decades, the rate of accidents in chemical industries has become considerably lower (Pasman et al., 2014). Nevertheless, some accidents involving toxic releases, fire and explosions continue to occur in major accident hazard industries and during transportation of hazardous chemicals in both the developed and developing parts of the world. Recent accidents at Sanganer (2009) in India, Moerdijk (2011) in the Netherlands, Lac Megantic (2013) in Canada, Geismar (2013) in the US show how such events can endanger the safety of people and cause considerable damage to property in the vicinity of the facilities.

The task of managing industrial emergencies can be very complex. Experience has shown that they may develop very rapidly, involve the consideration of factors that may change rapidly over time (e.g. weather conditions, traffic volumes, etc.), are often difficult to predict and require multiple actors to work in coordination to arrive quickly at decisions to protect the community and the environment (Georgiadou et al., 2007; Sorensen et al., 2004). Such dynamic and time sensitive requirements call for emergency managers having access to up-to-date and real-time information from several heterogeneous and multi-disciplinary sources in order to be able to make correct and fast decisions. The decision making requirements are most critical when an accident situation evolves and may involve rapid judgments that can be tentative, imprecise and approximate due to incomplete information, vagueness of human thinking and the inherent complexity and uncertainty of a rapidly evolving decision environment (Levy et al., 2007). Not having access to the right information at such a time will delay decision making, or adversely affect the quality of decision, leading to higher loss of lives and/or damage to property (Mansourian et al., 2006).

Application of DSS to find solutions to the complex set of problems involving different aspects of emergency management has been a favoured topic of research. Several integrated systems have been conceptualised in Europe to provide comprehensive information and modelling toolboxes for managing 
industrial accidents (Contini et al., 2000; Mazzini et al., 2002). Several other DSS tools focusing on optimization of emergency response and evacuation planning have been developed (de Silva, 2001; Georgiadou et al., 2007; Georgiadou et al., 2010; Levy et al., 2007). In India, considering the information needs for informing and driving industrial emergency preparedness planning and response in hazardous industry clusters, the ERRIS research project was initiated in 2004 which aimed at making relevant hazard and vulnerability information available to stakeholders through an online web-GIS based platform (Bandyopadhyay et al., 2013). However, initial planning of ERRIS did not account for the integration of a decision support module that could be used by a local level emergency management committee. Another parallel initiative was started by the MoEFCC to develop a GIS-based Emergency Planning and Response System (GEPR) for MAH industry clusters in select industrialized States in the Country (Gahlout et al., 2009). The initial version of the system was made available as a desktop version to administrators and response agencies while a later version is now available on the web. The tool has been deployed for several industry clusters across the country, but a review of its capabilities points to weaknesses in terms of the low resolution of spatial detail as well as lack of integration with intrinsic hazard modelling and decision support tools that can assist in realtime and dynamic decision making when a potential accident scenario unfolds.

The objective if this Chapter is to conceptualise and develop a distributed Emergency Decision Support System (EDSS) to aid local level decision making during emergency planning and response phases triggered by a potential industrial emergency. The design of the system takes into account the Indian regulatory and institutional context and the decision-making needs of actors involved in industrial emergency management. The EDSS would be able to access spatial and non-spatial information made available by the RMIS, couple analytical models for prediction of consequences from potential industrial accidents in order to support decision making and offer planning guidance during the preparedness and response phase of emergency management. Based on the conceptualisation, a prototype EDSS would be demonstrated based on few specific case examples for Haldia.

\subsection{Conceptualization}

\subsubsection{Emergency DSS Framework}

Like in several other countries, a regulatory framework that administers chemical emergency management in India, covering the phases of preparedness, planning and response exists. Two key regulations, MSIHC, 2000 and the EPPRCA, 1996 stipulate key requirements. MSIHC lays down emergency planning requirements that require MAH facilities and the 
administration to prepare and notify on-site and off-site emergency plans for an industrial area (GoI:MoEF, 2000). The EPPRCA focus on the institutional side and provide guidance for setting up a four-tier crisis management system in the country - involving the Central Crisis Group, the State Crisis Group, the District Crisis Group and the Local Crisis Group - to manage emergencies arising out of industrial operations (GoI:MoEF, 1996). However, a review committee set up by the government to assess effectiveness of regulatory provisions from the context of their implementation has pointed out several weaknesses. The key deficiencies include : no standardization of risk and hazard assessment methodology and codes of practice which often results in emergency plans that are not consistent and realistic; absence of sufficient and updated information with the emergency planning committees to plan for and respond to industrial emergencies; the lack of appropriately equipped emergency control rooms and associated infrastructure which can coordinate preparedness and response for industrial emergency situations (GoI:NDMA, 2007). Therefore, in the stakeholder consultations undertaken, it has been conveyed that local decision makers require support and assistance in efficiently planning for and responding to an industrial emergency.

Considering these problem elements of industrial emergency management in India, the framework for an Emergency Decision Support System (EDSS) is conceptualised and designed. The EDSS is based on the information system platform of RMIS and integrates complex time and space related data through a context driven SDI, knowledge management and expert system modules, analytical prediction models for predicting the consequences that can be triggered by an accident, GIS tools for spatial analysis capabilities and display of results, networking between different risk actors. The EDSS design is centred around the model based DSS architecture comprising of functionally related software modules proposed as early as 1986 by Armstrong (1986) and Densham (1991). The functioning of these fundamental building blocks of model-based DSS have been flexibly adapted using current and state-of-art service oriented architecture(SoA), web-GIS technology and networking protocols (Denzer, 2005; Drummond, 2008).

The challenge dealt with in the design of the EDSS architecture is to create effective integration and inter-play between the separate modules which will be involved - the database subsystem, modelling and knowledge subsystems, GIS sub-system and the user interface. Earlier developers involved with development and design of desktop based SDSS focused on an integration strategy involving a 'tight coupling' between the software components in order that components like GIS sub-system from the modelling sub-system can interact with each other, running simultaneously and exchanging data from a underlying database and operated through a common interface (Fedra, 1998; Malczewski, 1999). However, with 
movement of information systems towards Service Oriented Architectures (SoAs), there is a shift away from the earlier paradigm that involved such tight coupling to more flexible interaction between system modules. Therefore, the EDSS is planned as a collection of modular systems that can function through interoperable application environments, shared data spaces, and heterogeneous resource browser for exploring and analysing information residing in networked servers, all conforming to formal specifications and standards like the ISO or the OGC (An et al., 2010; Denzer, 2005; Vescoukis et al., 2012).

An important requirement catalysing the development of this EDSS framework is that it should be accessible and provide decision support functions to emergency managers, responders and other emergency actors, even though they may not have sufficient domain knowledge on industrial risks. Such approaches are increasingly being pursued in developing complex and integrated modelling tools for environmental and risk related problem solving (Laniak et al., 2013). The methodological approach to the development of the EDSS is further described in the sections below.

\subsubsection{Problem Structuring and User Needs}

Industrial emergency management is expected to involve the phases of mitigation, preparedness, response and recovery (Alexander, 2002; Haddow et al., 2013). From a decision support point of view, the preparedness and response phases require particular attention as they have to deal with shortterm response strategies prior to or during an emergency where information gaps or the inability to arrive at decisions, often under time-constrained situations may lead to costly mistakes resulting in loss of lives and property.

With the development philosophy assuming that the users need not be aware of intricacies involved in selecting appropriate models, data sets, modelling and visualization strategies, while operating the EDSS, it was important to understand the decision making needs and requirements of the local emergency management committee and other emergency actors. A stakeholder need analysis was undertaken for risk management actors at Haldia through a focused workshop, conducted as a part of the ERRIS project (Bandyopadhyay et al., 2008). In the workshop, a detailed task and activity analysis was undertaken to understand what kind of emergency tasks is expected to be performed by an actor and subsequently how the work is performed in a realistic work setting. A proto-type system, modelled based on the developers understanding, was made available to the participants. Then a hypothetical table-top mock drill exercise was initiated and the feedback of risk actors was sought on the functions and decision support capabilities that they would want to be integrated within the system. The feedback was subsequently validated through an actual mock drill conducted 
in one of the hazardous industries and its immediate neighbourhood by the Haldia City Administration. The following functions were listed as requirements from the EDSS:

Preparedness Phase Actions

- Provide information on hazard source and the hazardous chemical involved in the accident and their likely effects on health;

- Assessment of the number of people located in the direct surroundings of a potential MAH industry;

- Identify the most vulnerable critical facilities in the direct surroundings of potential MAH industries (e.g. schools, hospitals etc.);

- Support the preparation and conveying Off-site Emergency Plans to emergency actors;

- Assist in improving preparedness by providing information support to Mock Drills, identification of gaps and in deciding on appropriate mitigation measures to be adopted for potentially affected population;

Early Response Phase Actions

- Indicate the location of the accident and the type of accident;

- Predict the likely geographical spread of possible impacts caused by a hazardous accident taking into account factors like storage conditions, properties of chemicals released, atmospheric and weather conditions at that time and other factors; This information should be available as soon as possible after an event occurs, but at least within 15 minutes of an accident's occurrence;

- Notify industrial facilities in the direct surroundings to take emergency measures and stop certain processes that may cause additional hazard, if affected by the accident (e.g. closure of pipeline connections to tanks and processes);

- Convey to responders the location of exposed population and vulnerable objects (e.g. schools, elderly homes etc.);

- Inform responders on sites what might create additional risk as a consequence of the emergency through domino effects;

- Adjust the information on the affected areas through information coming from the ground and from other sensors (e.g. change in wind speed and direction);

Provide guidance to affected population to move to safe shelters or ask them to evacuate through proper routes;

- Interact with the emergency responders on-site (from the industry itself) and evaluate whether additional support is needed to stop the accident (e.g. in case of fire);

- Direct emergency responders to areas where search and rescue activities should be carried out, and under which circumstances (e.g. gas emissions, fire etc.); 
Identify evacuation locations in safe condition; Direct relevant support to these locations (medical, psychological, food and water);

Delayed Response Phase Actions

- Monitor the transport of injured people to hospitals, hospital capacity, setting up of temporary medical posts if needed;

- Indicate the areas where emergency responders have evacuated the population, and the sites that still need to be done;

- Provide relevant information to the media so that through the media the population in nearby areas is prepared;

- Evaluate effectiveness of response measures and evaluate potential alternative actions that may be available at the decision maker's disposal.

These information and decision support needs were then mapped to the emergency actors and to the actions involved in the emergency preparedness and response phases through a use-case diagram, which is shown in Figure 5-1. In the preparedness phase, hazardous industries are expected to develop on-site emergency management plans which identify risk scenarios that could possibly arise from different hazard sources and calculate potential consequences through hazard modelling. The on-site emergency management plans need to be reviewed and authorized by the regulators so that they could be utilized by the local emergency management committee to make an assessment of elements at risk / vulnerable receptors on a map, by using spatial association techniques, and come up with an area level emergency preparedness plan for the industrial cluster. Relevant sections of the plan could be shared with the community to make them aware of the hazards and the general precautions that need to be adopted in the event of an accident. Subsequently, during the response phase, the emergency preparedness plan will be executed by the administration together with emergency managers and responders to prioritise actions like evacuation or shelter-at-place or to optimise movement of emergency vehicles through safer routes. 


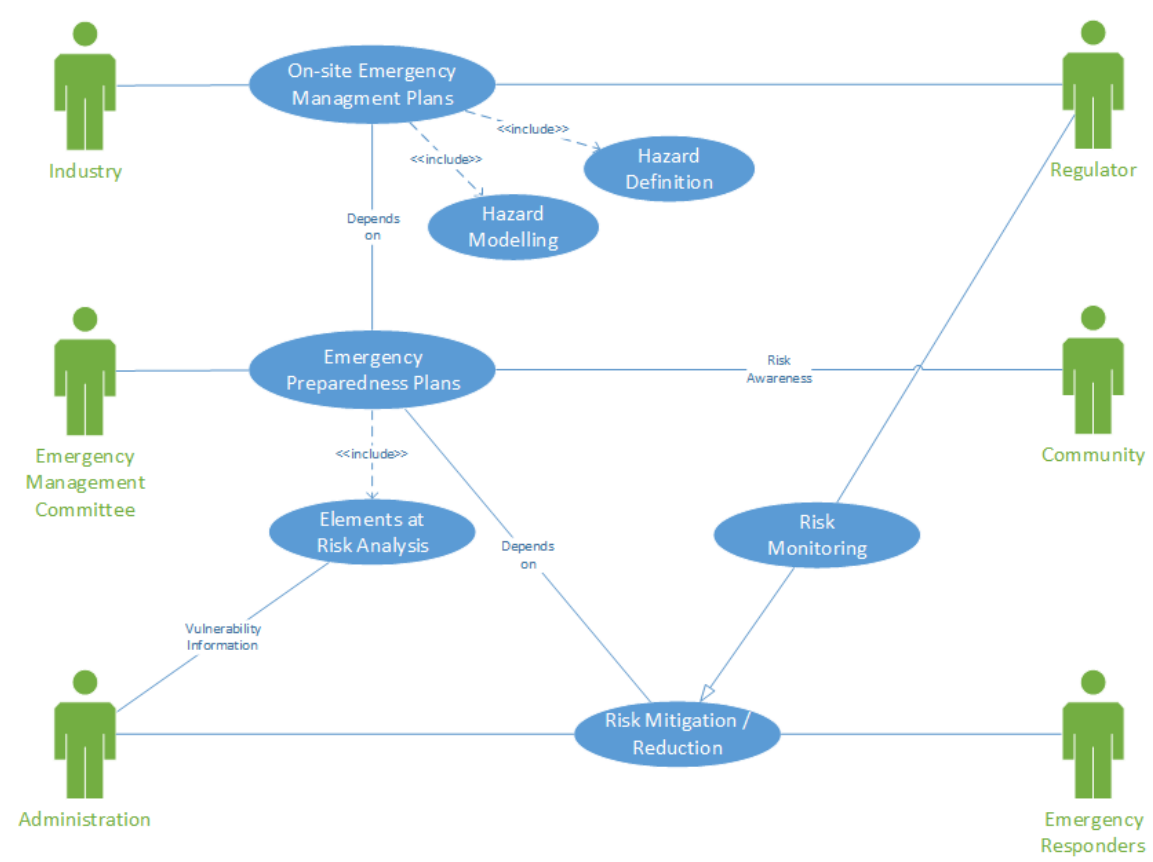

Figure 5-1: Use Case Diagram for Industrial Emergency Management

\subsubsection{Data Sharing and Exchange}

The management of an industrial emergency situation requires actors to efficiently draw upon information from multiple and diverse sources, and often with a strong spatial correlation - the location of hazard, the orientation and spread of the hazard footprint, the location of vulnerable population and receptors, the spatial layout of transportation links to be used for evacuation or response (MacFarlane, 2005; NRC, 2007; SNDR, 2002; Zlatanova et al., 2009). In fact, the availability of updated and valid information, from these sources with associated tools and services like querying and spatial association, is often considered to provide the first level of DSS services to the risk actors (Black et al., 2009). An example for such decision support may be to find out the estimated population that lives within $500 \mathrm{~m}$ of a hazard source, where an accident has occurred.

Being developed on the RMIS platform, earlier deployed in Haldia as a part of the ERRIS (Bandyopadhyay et al., 2013), the EDSS conception integrates the provision for fundamental building blocks of information through the provision of interoperable geo-spatial data services which would be available through context aware SDI's: 
- Information about hazardous chemical storage, mobile sources and pipelines from industry, with mobile storage locations being tracked through GPSs;

- Estimated population distribution data for different times of the day, interpolated at a $100 \times 100$ m grid level from administration;

- Building specific vulnerability data; Responder data from Police and Fire Brigade,

- Real time meteorological data from Sensor based services.

With foundation laid on a SDI oriented framework, the EDSS would be in a position to consolidate and analyse data from disparate sources providing results through a thin client interface of a web browser to aid decision making at the end of the emergency manager. This would be possible as the data would conform to OGC based standards like WMS, WFS, Sensor web (OGC, 2003) and based on clearly specified interfaces, encoding and protocols and resultantly be available for forward linkage with interoperable geo-processing services, modelling tools and knowledge bases (An et al., 2010). The compatible design of the underlying data schemas through UMLs would allow for necessary cross-referencing between multiple data sources (Chen et al., 2008; Dilo et al., 2011).

\subsubsection{Consequence Modeling}

A key aspect of managing an industrial emergency related to a chemical accident is the ability to predict the probable hazard footprint of the event to be able to understand likely consequences in terms of population vulnerability and effect on sensitive receptors and then arrive at decisions to safeguard or evacuate them. The prediction of the physical consequences is complex and requires understanding of the spatial spread of the likely physical impacts spread of toxic gas cloud, extent affected by radiation exposure or by overpressure. Typically, once accidental hazard scenarios have been established through the process of risk identification, mathematical algorithms are used as a part of a consequence analysis to estimate the physical effect that may be caused by the incident and the potential impact it may have in terms of injuries or fatalities, damage to property or damage to the biophysical environment. The physical phenomenon involved in an accident being considered (mainly, toxic release, fire or explosion) is dependent on the nature and type of hazardous chemicals and specific information on hazardous storages located within fixed installations or ones involved in transportation - mobile tankers and pipelines. The effect of an accidental event is also influenced by factors extrinsic to the hazard source like meteorological conditions and the presence of physical features in the affected zone, which can act as barriers and reduce the impact of the physical spread to the hazard. 
After the physical effects are predicted, generally as a function of a distance from the hazard source, the consequences of these accidents is determined based on specific end-points:

- for toxic release, it is the concentration of the gas in air in parts per million (ppm);

for radiation, it radiant energy flux measured in Kilowatt per square meter $\left(\mathrm{KW} / \mathrm{m}^{2}\right)$;

- for explosion the overpressure in pounds per square inch (psi).

The end-points are developed based on dose-response relationships, which materialise from a combination of results from animal experiments, observations of long- and short-term human exposures, and expert judgment. For emergency response purposes, the level of concern or endpoint is considered to be at a threshold where potential damages to human health may occur. For example, for toxic releases, the level of concern for an airborne gas is expressed as a specified concentration over a set time period of measurement and for a defined population group set up by government agencies and professional organisations. It can be expressed as the three tier Emergency Response Planning Guidelines (ERPGs) levels of concern published by the American Industrial Hygiene Association (AIHA) (American Industrial Hygiene Association) or the Immediately Dangerous to Life or Health (IDLH) levels defined by the US National Institute for Occupational Health and Safety (NIOSH). They provide exposure concentrations to airborne contaminants that is likely to cause death or immediate or delayed permanent adverse health effects or prevent escape from such an environment. For EDSS, the algorithms for calculation of end-point distances are detailed out in Table 5-1.

Table 5-1: Effects Models integrated with EDSS

\begin{tabular}{lll}
$\begin{array}{l}\text { Physical } \\
\text { Effect of } \\
\text { Accident }\end{array}$ & Type of Model & Algorithm \\
\hline $\begin{array}{l}\text { Toxic Gas } \\
\text { Release }\end{array}$ & $\begin{array}{l}\text { Gaussian Puff } \\
\text { Dispersion model }\end{array}$ & $C(x, y, z)=\frac{G}{(2 \pi)^{\beta / 2} \sigma_{x} \sigma_{y} \sigma_{z}} \exp \left[-\frac{1}{2}\left(\frac{y}{\sigma_{y}}\right)^{2}\right] \exp \left[-\frac{1}{2}\left(\frac{x-u t}{\sigma_{x}}\right)^{2}\right]$
\end{tabular}

Eqn. 5.1

$\mathrm{C} \rightarrow$ time average concentration (mass/volume)

$\mathrm{G} \rightarrow$ total mass of material released (mass)

$\sigma_{x}, \sigma_{y}, \sigma_{z} \rightarrow$ dispersion co-efficient in $x, y, z$ direction

$y \rightarrow$ cross wind distance (length)

$Z \rightarrow$ distance above ground (length)

\begin{tabular}{lll} 
& $\mathrm{H} \rightarrow$ release height above ground. \\
\hline Pool Fire & $\begin{array}{l}\text { Solid Plume } \\
\text { Radiation Model; } \\
\text { Combination of }\end{array}$ & $\mathrm{Er}=\tau_{a} \Delta H_{c} F_{21}$ \\
$\begin{array}{l}\text { Several models } \\
\text { (burning rate, } \\
\text { pool size, flame }\end{array}$ & $\mathrm{E} r \ldots .$. Eqn. 5.2 \\
&
\end{tabular}




\begin{tabular}{|c|c|c|}
\hline & $\begin{array}{l}\text { geometry, flame } \\
\text { surface, emitted } \\
\text { power, geometric } \\
\text { view factor, } \\
\text { atmospheric } \\
\text { transmissivity, } \\
\text { received thermal } \\
\text { flux) }\end{array}$ & $\begin{array}{l}\tau_{a} \rightarrow \text { Atmospheric transitivity } \\
\Delta H_{c} \rightarrow \text { heat of combustion for burning liquid } \\
\text { (energy/mass) } \\
F_{21} \rightarrow \text { solid plume view factor. } \\
F_{21}=\frac{H(D / 2)^{2}}{\left(L^{2}+H^{2}\right)^{3 / 2}} \\
\text { If } L>D / 2 \text { of fireball } \\
F_{21}=\frac{L(D / 2)^{2}}{\left(L^{2}+H^{2}\right)^{3 / 2}} \\
\mathrm{H} \rightarrow \text { height of fireball centre from ground } \\
\mathrm{L} \rightarrow \text { distance from point at ground below fireball } \\
\text { centre to receptor at ground level. } \\
\mathrm{D} \rightarrow \text { diameter of fire ball. }\end{array}$ \\
\hline $\begin{array}{l}\text { Vapour } \\
\text { Cloud } \\
\text { Explosion }\end{array}$ & $\begin{array}{l}\text { TNT equivalence } \\
\text { model }\end{array}$ & 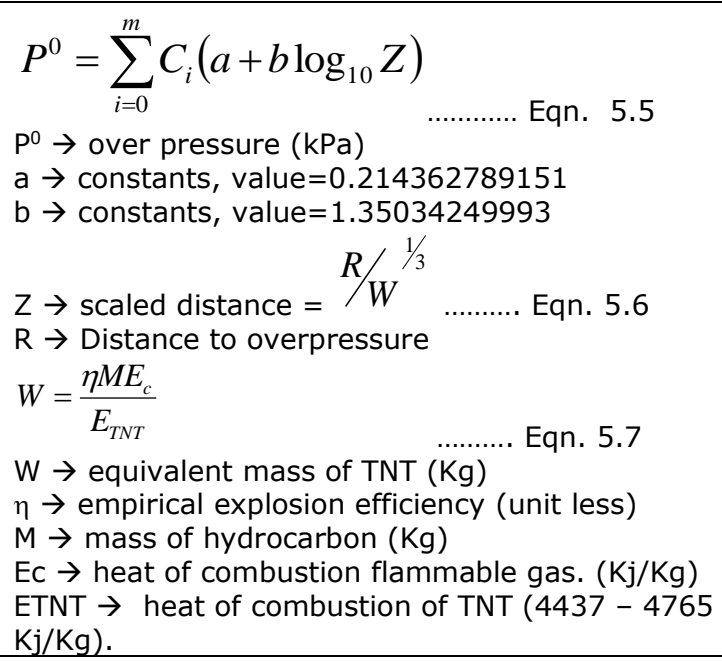 \\
\hline BLEVE & $\begin{array}{l}\text { Fireball Surface } \\
\text { Emitted Flux } \\
\text { model }\end{array}$ & $\begin{array}{l}E r=\frac{2.2 \tau_{d} R H_{c} M^{2 / 3}}{4 \pi X_{c}^{z}} \\
\text { Where } \\
E r \rightarrow \text { radiative flux received by receptor }\left(\mathrm{W} / \mathrm{m}^{2}\right) \\
\tau_{\mathrm{a}} \rightarrow \text { atmospheric transmissivity (unit less) }= \\
2.02(\mathrm{PwXS})-0.09 \\
\mathrm{R} \rightarrow \text { radiative fraction of heat of combustion (unit } \\
\text { less) } \\
\mathrm{H}_{\mathrm{c}} \rightarrow \text { net heat of combustion per unit mass }(\mathrm{J} / \mathrm{kg} \text { ) } \\
\mathrm{M} \rightarrow \text { initial mass of fuel in fire ball }(\mathrm{kg}) \\
\mathrm{Xc} \rightarrow \text { distance from fireball centre to receptor } \\
\left.\mathrm{PW} \rightarrow \text { water partial pressure (pascals, } \mathrm{N} / \mathrm{m}^{2}\right) \\
\mathrm{Xs} \rightarrow \text { path length distance form flame surface to } \\
\text { target }(\mathrm{m})\end{array}$ \\
\hline
\end{tabular}

(AIChE/CCPS, 2000) 


\subsection{Design and Implementation}

\subsubsection{Information Service and Knowledge Base}

The EDSS is designed to provide predictions of the effects of an accident based on integration of consequence models with spatial and non-spatial data on elements at risk, response agencies, sensor data, etc. Such data is available either from the RMIS native database or as interoperable data services at various stages of the decision support process. The data and information requirements are schematically shown in Figure 5-2.

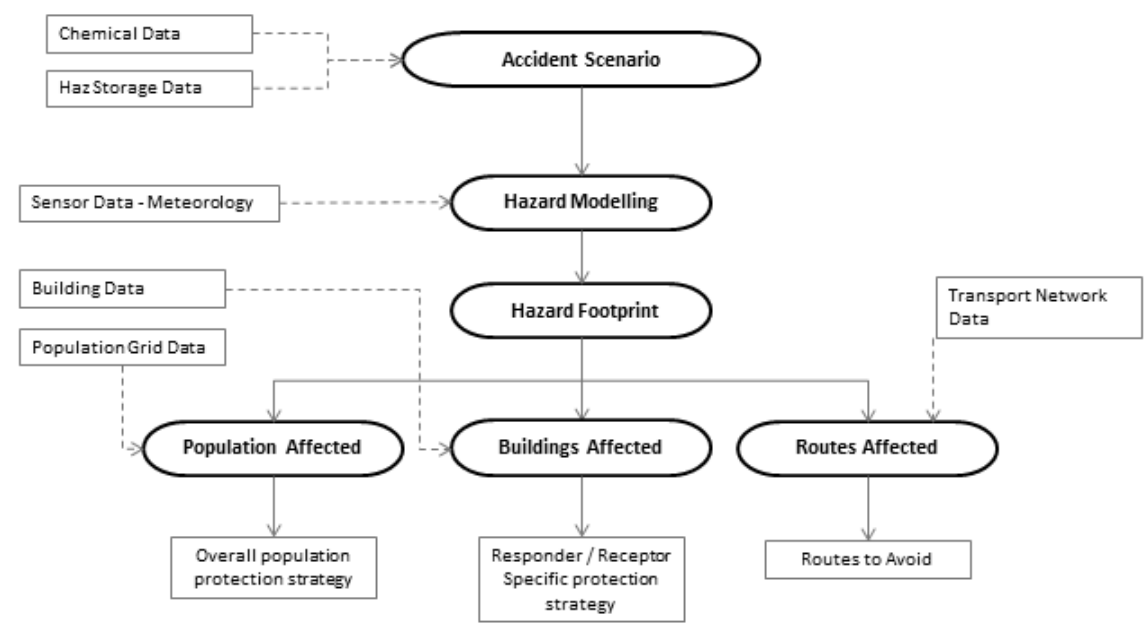

Figure 5-2: Data and information services required by EDSS

It is expected that the EDSS will be the primary tool to be used to inform and aid decision making of the local emergency planning committee (LEPC), with an emergency response coordinator (ERC) being in charge of the system in an Emergency Control Room. With the EDSS operating in response mode, once an accident notification is received at the control room including first level of information about the hazard source, the ERC will have at disposal a set of reference hazard scenarios for each hazard source in the area. These scenarios are outcomes of industry specific risk assessment process and are stored in the RMIS risk assessment database.

If however, the ERC would like to be facilitated in generating a dynamic accident scenario to predict the nature, extent and severity of an industrial hazard triggered by an industrial accident, an expert system is integrated in the hazard modelling toolbox and interacts with the user through the inference engine. The expert system follows a set of rules, dynamically defining a step-wise sequence to solve the emergency task-at-hand that will 
aid a decision making process (Fedra et al., 2002). The rule base, acting on a forward chaining mode, provides the flexibility to extend pre-defined sequence of actions based on the dynamic context of an emergency situation posed by a certain hazard. A forward chaining rule base is a data driven set of rules that draw new conclusions from existing data to form a dynamically evolving knowledge base (Liebowitz, 1997 66).

At the core of the advisory module in EDSS is the knowledge base that encodes domain expertise and technical protocols on industrial hazard prediction which collaborates with an inference engine to accomplish the task through a series of sequential actions. At the first level, the rule base guides the user on the choice of potential events that can occur from a particular storage based on the chemical stored, conditions of storage and prevailing meteorological conditions. At the second level, the rule base guides the user in the selection of an effects model to be triggered and selection of the endpoints at which the consequences can be considered to be of concern. The knowledge base in the expert system, interfaces with the user through the Hazard Modeller and provides guidance based on the rule base, linking real time information (meteorological information) with databases (hazardous storage properties and nature of chemicals) and the GIS layers (location of storages). Resultantly, the user can trigger appropriate hazard modelling algorithms to predict the severity and extent of damage from a probable accident.

The sequence of tasks for predicting the damage caused by a hazardous accident, depending on the dynamic context, can be defined by a set of forward chaining rules. They are represented using a XML notation and is of the general form of expression:

IF [condition]

AND [condition]

OR [condition]

THEN [action]

As an illustration, Box 5-1 shows how the logic of an event tree is codified as a rule base for particular conditions of storage and the hazardous properties of chemical. Based on the rule base, a choice of type of hazard, which may comprise of a Toxic Release (TR), Vapour Could Explosion (VCE), Boiling liquid expanding vapour explosion(BLEVE) or Pool Fire (PF), can be explicitly suggested to the user for selection and based on which the action comprising of the triggering of a effects model occurs. It logically reasons that 'if' the chemical involved in an accident is both toxic (e.g. having IDLH less than $1500 \mathrm{ppm}$ ) and flammable 'and' condition of storage of a chemical represents a given state (e.g. liquid under Normal Temperature and Pressure), 'then' the 
nature of the hazardous event to be modelled could be a TR, VCE or a PF. The possibility of other potential accidental scenarios is also similarly worked out in subsequent rules.

In addition to this sequentially driven approach, the expert system can also import data associated with a stored hazard scenario from the scenario database, with a scope for accepting changes to pertinent scenario in an asynchronous manner based on near real time data and other pertinent information obtained from the accident site. With the EDSS gaining maturity, it is expected that further rule sets will be formulated based on consensus amongst emergency management experts and other actors and then be integrated into the expert system module.

Box 5-1: Illustration of Rule Set for guiding selection of Effect Model based on chemical properties and storage conditions

IF flammable AND If the Environmental condition is Liquid Under NTP

then Risk Event=VCE and PF

If IDLH $<1500$

then Risk Event=VCE, PF and TR

If the Environmental condition is Gas Under NTP then Risk Event=VCE

If IDLH $<1500$ then Risk Event=VCE and TR

If the Environmental condition is Liquefied Gas under

Pressure

then Risk Event=VCE and BLEVE

If IDLH $<1500$

then Risk Event=VCE, BLEVE and TR

If the Environmental condition is Liquefied Gas under

Refrigeration

then Risk Event=VCE, BLEVE and PF

If IDLH $<1500$

then Risk Event=VCE, BLEVE, PF and TR

IF NOT Flammable AND IDLH $<1500$

then Risk Event=TR

\subsubsection{Workflow Modeling}

In order to understand the workflow involving the different components of the EDSS, the handling of a specific scenario is presented through a UML sequence diagram to portray interaction with actors, user interfaces and objects within the system. Figure 5-3 represents the sequence of the workflow from the time an user starts interacting with the EDSS till the outputs to aid decision making is presented to the user. In step (1) and (2), the user logs in to the system and starts operating the Hazard Modeling tool. In step (3), the Hazard Modeling wizard is initiatited, working with 
information of a accident involving a particular hazardous storage, the knowledge base guides the user to create a scenario to model using sequential steps (4), (5), (6) and (7) to interact with the user and obtain information from the underlying RMIS database. After the hazard model is triggered and the computation is undertaken, the hazard map object creation request is processed through the map engine through step (8), followed by the map rendering request and subsequent rendering of the hazard map on the RMIS visualization interface. In parallel, utilising steps (10) and (11), the system queries the database to return vulnerability information through a separate pop-up window.

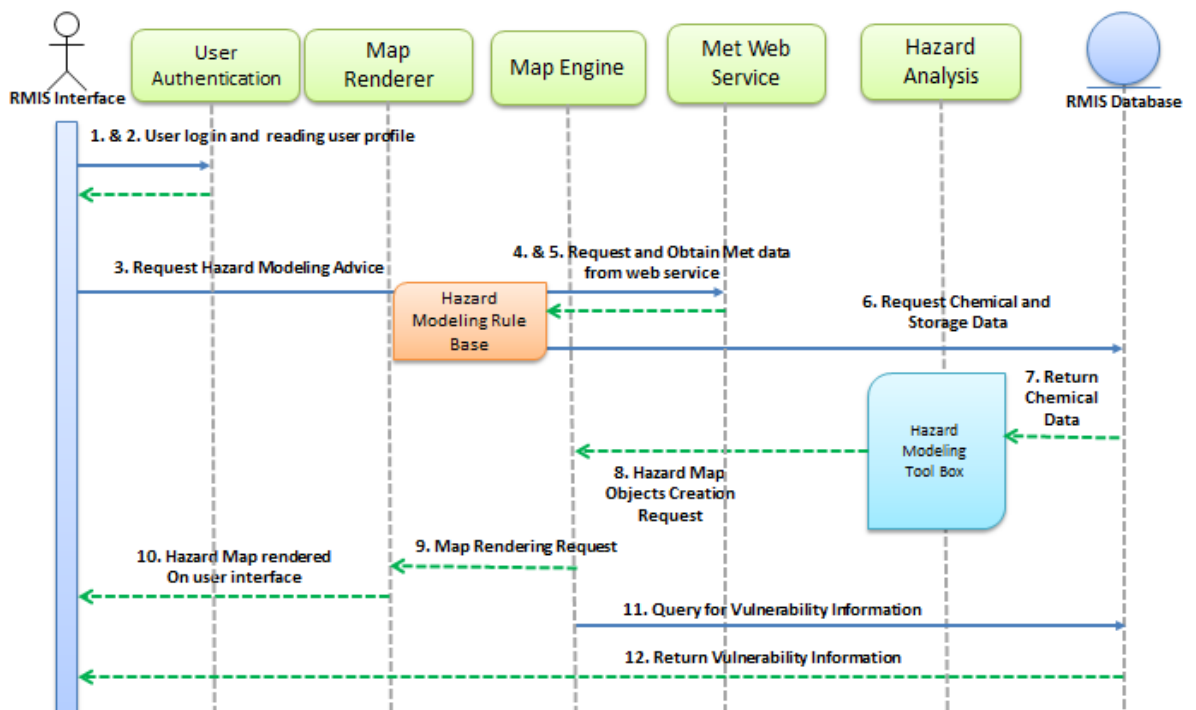

Figure 5-3: UML Sequence Diagram for Consequence Modeling Workflow

\subsubsection{System Architecture}

The EDSS functions on the three-layered hierarchical architecture of the RMIS platform. The abstracted form of the architecture is shown in Figure 5-4 and the function of each tier is as follows:

- The data and knowledge tier stores the domain specific information in the SQL Server relational database, which can be consumed by the application layer for hazard modelling or can directly be used in the presentation layer for providing contextual spatial and attribute information to the user. This includes the industry, storage, chemical and accident scenario databases, which has been described in detail in Chapter 4.

- The application tier contains the sensor web service feeding near real time data from a meteorological station, a rule based expert system that 
guides the user through the hazard modelling process, effect modelling algorithms for hazard estimation and spatial analysis tools for calculating possible damages. WMS /WFS information services like population grid and buildings are integrated in this tier from respective context sensitive SDIs. In addition, this tier also uses a map engine component that processes the logic for retrieval of spatial and related non-spatial data sets from the geo-database so that it can be used for analysis.

- The presentation tier supports the hazard modelling task and puts across to the user a visualization of the hazard's potential outcome. It comprises of the Consequence Modeller wizard that facilitates the modelling process by interacting with the user on one side and the application and data tiers on the other to undertake a predictive model run. The web-map based interface then presents a visual representation of the hazard through the graphical presentation of the hazard footprint as per different levels of concern for the hazard and associated information to the user. In addition, the generic user interface in this tier also supports display and querying functions for information related to hazards and vulnerabilities along with the capability to retrieve non-spatial information like data on chemicals or meteorology from linked menu options.

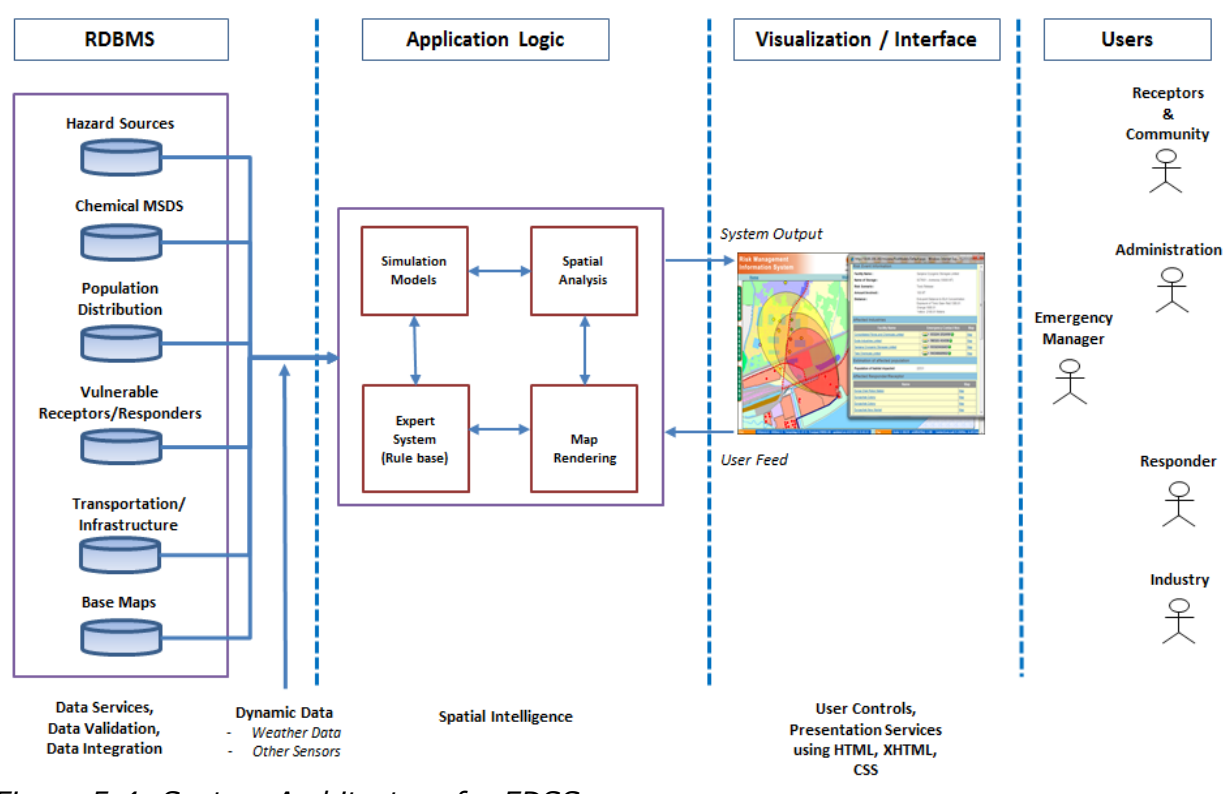

Figure 5-4: System Architecture for EDSS

\subsubsection{User Interface and Visualization}

The user interface for undertaking the modelling of a hazard in order to predict the likely consequence of an accident and associate information to 
guide emergency planning and response is provided by the Consequence Modeller tool. The tool can be used in two different ways. In the first option, if the probable scenario is stored in the Risk Scenario Database, as a result of a previously undertaken risk assessment process, the scenario can be imported with scope for suitable modifications to be made before initiating a model run. In the second option, when a probable scenario is non-existent in the database and it can be built using the intuitive wizard integrated with Consequence Modeller tool. The wizard has been designed to guide an user through the logical steps of providing inputs to the system and comprises the following 4 interface screens:

- Providing meteorological information or importing it from a near real time meteorological station installed in the area;

- Identifying the facility and storage involved in the accident and the nature of the event;

- Providing information about the release quantity, time and / or rate and levels of concern or using the information from the scenarios stored in the Risk Scenario Database;

The screens for the wizard are shown in the Figure 5-5. 


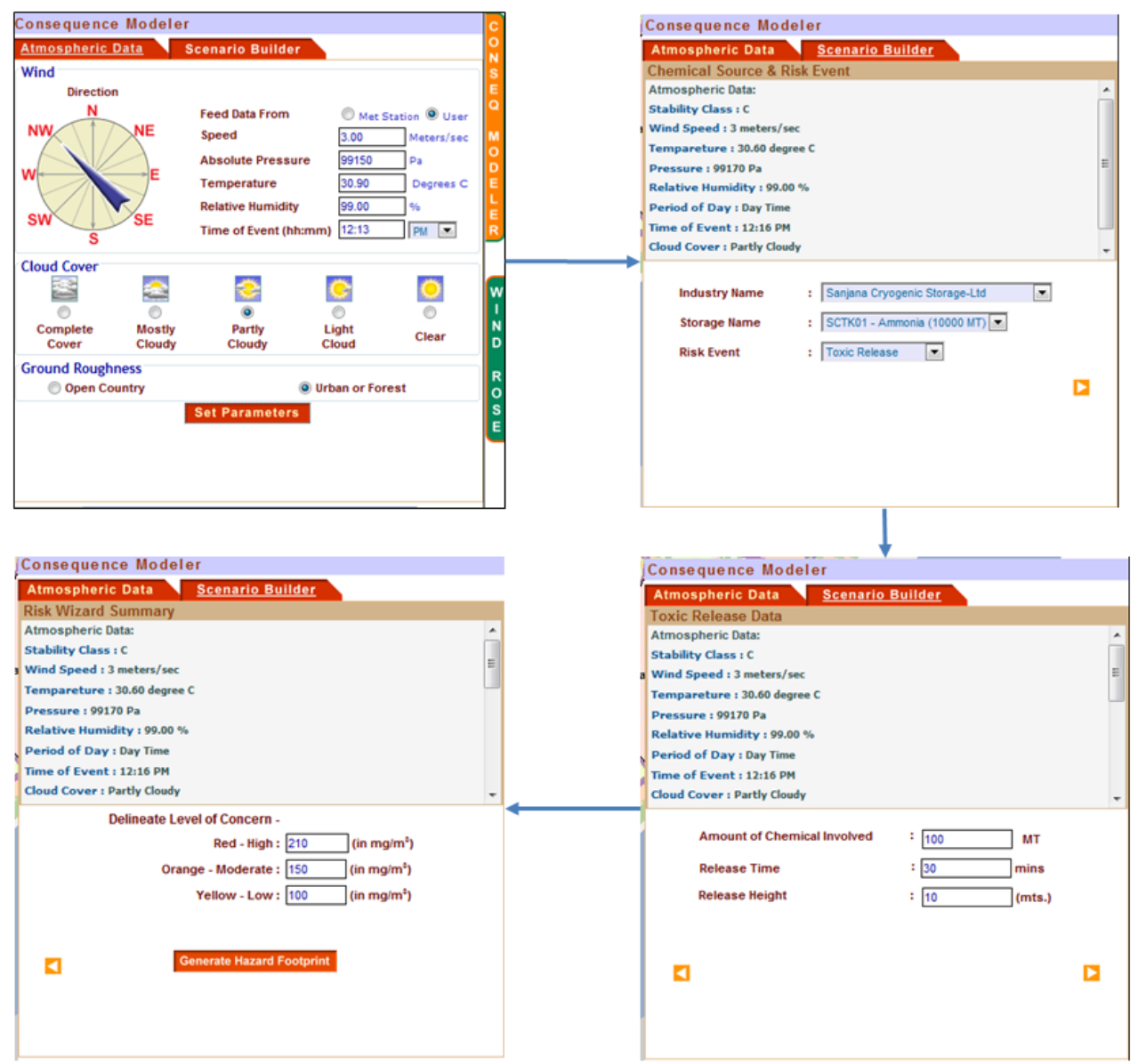

Figure 5-5: Flow of Wizard Interfaces for Hazard Modeller

The output of the model runs are projected as hazard footprints on the RMIS interface as a feature layer, visualized in graded colours in order to designate different levels of concern, and overlaid on the other map layers. For example, the footprint for a toxic gas is represented as an ellipsoid shape with the point of origin located at hazard source and its major axis aligned with the direction of wind blow. The hazard footprint is also used for geometrically intersecting underlying layers and its spatial reference used to query and analyse feature information for these layers e.g. summation of population from the grid population layer and information from the storage and building layers.

\subsubsection{Interoperability}

Interoperability of scenario specific information is enabled by extending a particular scenario from the Risk Scenario Database, which stores potential 
accident scenarios for each storage of hazardous substance based on industry level risk assessment exercise and can be validated by regulators, as Extensible Mark-up Language (XML). The Hazard Modeller Tool which provides knowledge based guidance to a user for formulating an accident scenario also provides the option to export the scenario outcome as an XML file. The primary reason for using XML is to explore the possibility for exchanging of data across other risk information systems, particularly through the internet, provided a common tag based template is maintained. The XML can encapsulate data based on common consequence assessment data requirements under the tags accident category, meteorology, chemical properties, environmental conditions, event data and output distances for three levels of concern - red, orange and yellow. Using such a standardised template, it would also be possible to share scenario data with compatible systems maintained by other risk-actors, having similar data requirements, through the export of the Scenario XML.

In addition, the system provides the functionality to export the results of the model run, in the form of a spatial footprint, as a Keyhole Mark-up Language (KML) file, which can then be viewed and interpreted by potential users outside the EDSS through the Google Earth viewer interface. For generating the $\mathrm{kml}$ file of the hazard footprint, a request is sent to the Hazard Modelling Toolbox which responds with feature objects. The OpenLayers accepts the feature object, and converts it to $\mathrm{kml}$ using the "openlayer.format. kml" class.

\subsection{Demonstration of Prototype Emergency DSS}

In order to demonstrate the functionalities of the EDDS in aiding decision making during the preparedness and response phases of an industrial emergency in Haldia, we explore the use of the system considering three potential emergency scenarios and their treatment using the system: Scenario 1 and 2 being run in the preparedness mode and the Scenario 3 being run in the response mode. In all the cases, it is considered that the emergency management planning and response is guided from an emergency control room located within Haldia with an emergency coordinator being the principal person in charge of operating EDSS. The functions demonstrated include the use of the knowledge and expert system of the system, the modelling of consequences and the guidance provided in terms of identification of vulnerable population, receptors, transportation links, and potential domino effects from other industrial storages which could be affected.

In the first scenario, a release of toxic ammonia gas is considered from the fixed source cryogenic storage SCTK01 of industry XY03 having a capacity of 10,000 MT. Once the accident scenario to be run is selected as a part of the preparedness planning process, the Consequence Modeller tool is initiated 
from the EDSS interface. The prevailing wind speed and direction for the scenario is to be selected based on the average wind speed and directions prevailing at the time of the year. Alternatively, if undertaken during response phase, the near real time meteorological information available from the last instance of the data feed from an online meteorological sensor present in the area may be considered as input. For this scenario, wind speed is considered to be $3 \mathrm{~m} / \mathrm{sec}$ and with the direction of wind blow from the SE to the NW. Based on risk assessment undertaken by the facility, it considers several reference hazard scenarios, one of which involves the release of 80MT of the toxic gas over a period of 30 minutes, at an average rate of 2.66 MT per min. The scenario is imported from the Risk Scenario database, to which a link is provided from the Consequence Modeller interface. Once the scenario is run, the result in terms of a directional hazard footprint, aligned with the wind direction and comprising of vulnerability zones to predetermined end-points are shown as a semi-transparent layer as yellow, orange and red zones. They represent three increasing levels of concern in accordance to risk assessment practice, based on exposure levels delineated as IDLH or EPRG. Figure 5-6 presents visual interface presented by the EDSS.

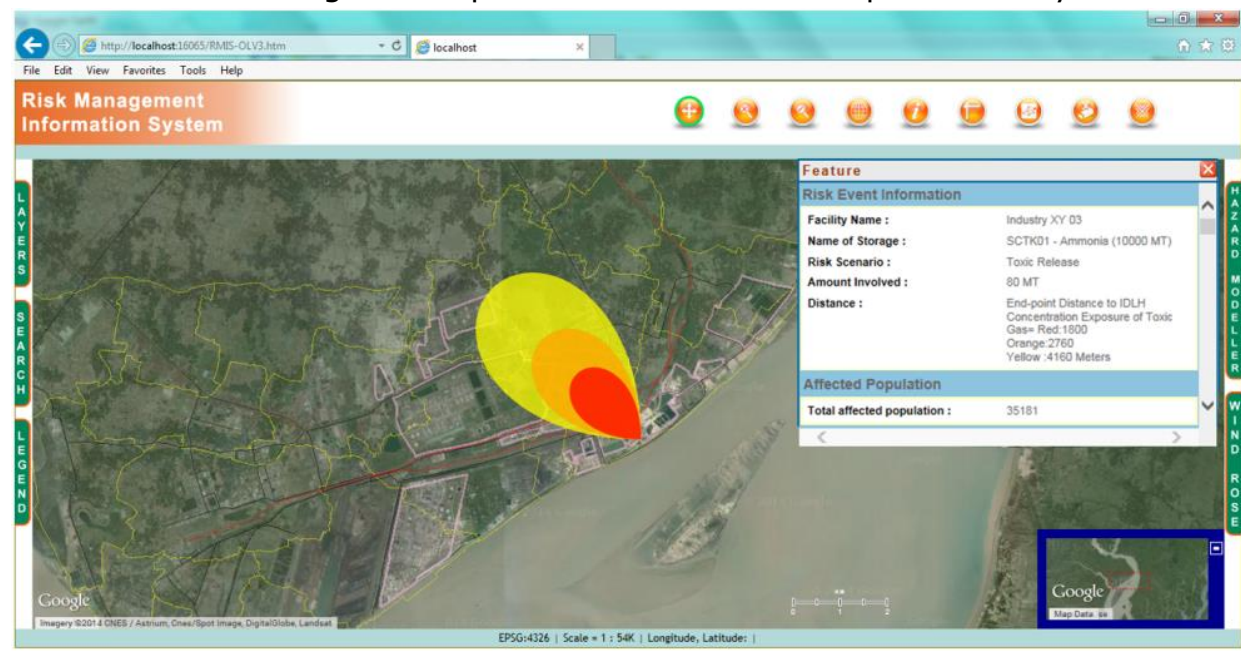

Figure 5-6: Hazard footprint and associated vulnerability information from an ammonia release scenario

A pop-up information window is also triggered by the system, which will provide relevant information to the coordinator, thereby aiding in drawing up a preparedness plan for such an event. They information details provided are as follows:

- Distances (in m's) to the 3 end-points as predicted by the consequence model (red - 1800, orange - 2760 and yellow- 4160); 
- Indicative population of about 35181 people who may get impacted by the scenario and may require advice on in-house sheltering or evacuation;

- Other neighbouring industries, their emergency contacts which may be impacted by the scenario footprint along with information on storage capacities and the chemicals they store;

- Sensitive receptors like schools, hospitals and potential responders like Police and Fire Brigade who may be impacted;

- Nodes of transportation infrastructure like roads and railways that may be affected by the hazard footprint.

Further information in terms of possible on-site and off-site response capabilities present in the area, the possible mitigation and population protective actions that needs to be taken for Ammonia, further details on sensitive receptors, which can help prioritising an area level emergency preparedness and response plan can be queried from the interface, using interrelated databases.

It is possible to save the outcome of a hazard scenario simulated along with supplementary information in the Hazard Outcome Scenario Database. The stored scenario can then be made available at a later time to other planning or response agencies even if they are remotely located from the emergency operation room, thereby promoting information sharing and collaboration between actors. In addition, it is also possible to save the scenario outcome as a $\mathrm{kml}$ file and then view the information through the Google Earth interface. The result of the scenario, when exported and then viewed through Google Earth is shown in Figure 5-7.

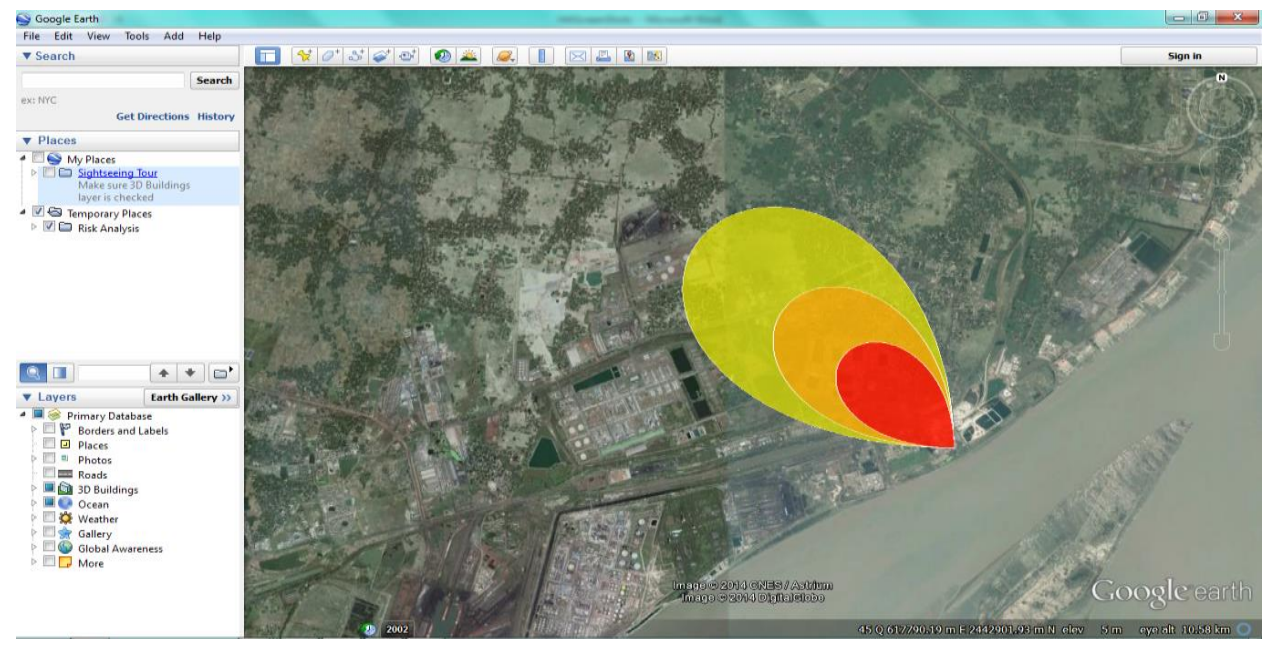

Figure 5-7: Toxic Release Plume Footprint exported as $\mathrm{kml}$ and visualized through Google Earth interface. 
In the second scenario, an accidental event involving a mobile hazard source is considered in the preparedness phase. The point of origin of the hazard is assumed as an accident caused by a collision of a LPG carrying road tanker with another vehicle. The collision results in the leakage of LPG leading to the formation of a flammable vapour cloud which explodes after finding a source of ignition. It is estimated that the entire amount of LPG stored in the tanker, which is about 10 MT was involved in the accident.

The area of the accident on a road can be located using the GIS functionality through the EDSS interface. Then, using the Transportation Emergency Locator tool, the user can insert a new point at the approximate location and enter basic required information on the accident scenario in the pop-up dialog that is triggered by the system. Subsequently, using the sequential steps provided by the Consequence Modelling wizard, the user can generate a hazard footprint for 3 levels of overpressure generated by the VCE.

On running the scenario, the EDSS invokes the VCE consequence model and analyses spatial data to provide both as radial hazard footprint and associated information output, which is presented in Figure 5-8. The EDSS also presents relevant vulnerability information and can assist the emergency planning team to work out specific details of a transportation safety and emergency response plan for that stretch of road with a number of adjacent hazardous industries and chemical storages that may be potentially impacted by the accident.

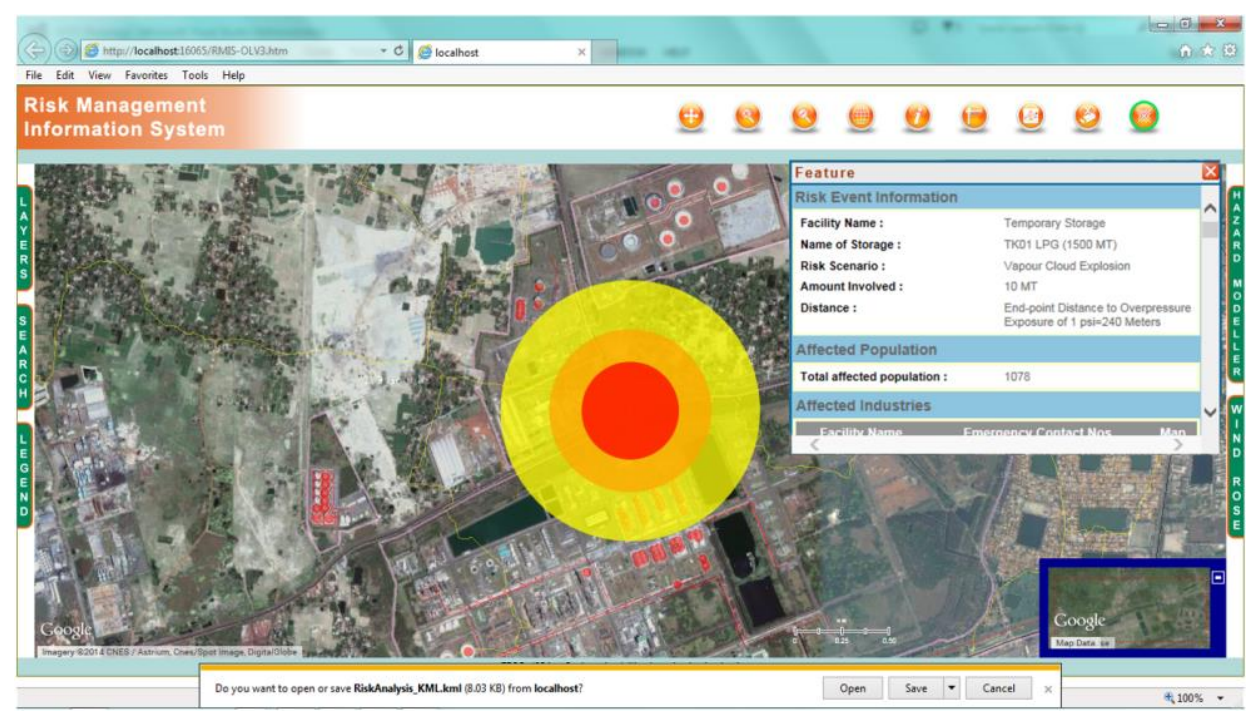

Figure 5-8: Hazard footprint and associated vulnerability information from transportation accident BLEVE involving 10 MT LPG 
Scenario 3 involves a demonstration in the response mode. In order to understand the functionality of the EDSS, a storyboard describing the situational context of potential accident scenario from its initiation to the end of the accidental fall out is discussed below.

It is a normal and busy morning at Haldia on 1st of July, 2015. Industries are functioning, people on their way to work, children on their way to school, markets are opening. Suddenly, a phone call comes to the Emergency Response Center from a person stating that he can strongly smell petroleum that is used as car fuel. He says he is located close to Industry XY12. The phone call is logged by the Emergency Coordinator at $8.30 \mathrm{am}$. During the time, wind was blowing inland from the river.

The emergency coordinator uses the GIS navigation and query functions to identify the hazardous storages inside Industry XY12 and in the immediate vicinity to try and identify if any storages of Motor Spirit is present - query and results show Industries XY 05 and XY 16 to be having storages of Motor Spirit.

At 8.40am, an industry representative from Industry XY16 calls the Emergency Response Center to state that significant volumes of Motor Spirit is leaking from the Tank TK11 storing about 7000 MT of Motor Spirit at an estimated rate of $30 \mathrm{MT} / \mathrm{min}$ for the last 30 minutes. The onsite response team is unable to control the leakage because of a major equipment failure.

Further level of enquiry into the Material Safety Data Sheet (MSDS) of Motor Spirit shows that it is highly inflammable, has low Vapour Pressure of 0.5 1.25 , Flash Point of $40^{\circ} \mathrm{C}$ and can form an explosive mixture with air with a LEL of $1.4 \%$. The Emergency Coordinator initiates the Hazard Modeller Tool of the EDSS in order to understand the extent and severity of potential consequences, in the case the vapour cloud explodes after finding a source of ignition. The following information in Table 5-2 is used for the modelling.

Table 5-2: Information for Modelling

\begin{tabular}{ll}
\hline Atmospheric Conditions & Source Data \\
\hline Wind Speed : $2 \mathrm{~m} / \mathrm{sec}$ & Continuous Release: 30 tons/min \\
Wind Direction: Towards North West & Duration: $30 \mathrm{~min}$ \\
Temperature: $30^{\circ} \mathrm{C}$ & Release Height: $12 \mathrm{~m}$ \\
Cloud Cover: Clear Day & Overpressure Endpoints - 5, 3,1 psi \\
Stability Class: B & \\
\hline
\end{tabular}

The hazard scenario outcome in Figure 5-9 shows that significant damages can be caused by the VCE with the 1 psi end-point extending to $540 \mathrm{~m}$ from the origin (i.e. the location of Tank TK11) and affecting an estimated 16972 people in the densely populated Durgachak area of Haldia. The accident can 
potentially cause domino effects to about 10 neighbouring industries ( $X Y 01$, XY03，XY05, XY06, XY09, XY10, XY12, XY17), including other storages present in Industry $\mathrm{XY} 16$ with possibility of additional damages. 9 sensitive receptors including schools, hospitals, a nearby police station as also all major roads leading up to Industry XY16 might be impacted by the accident.

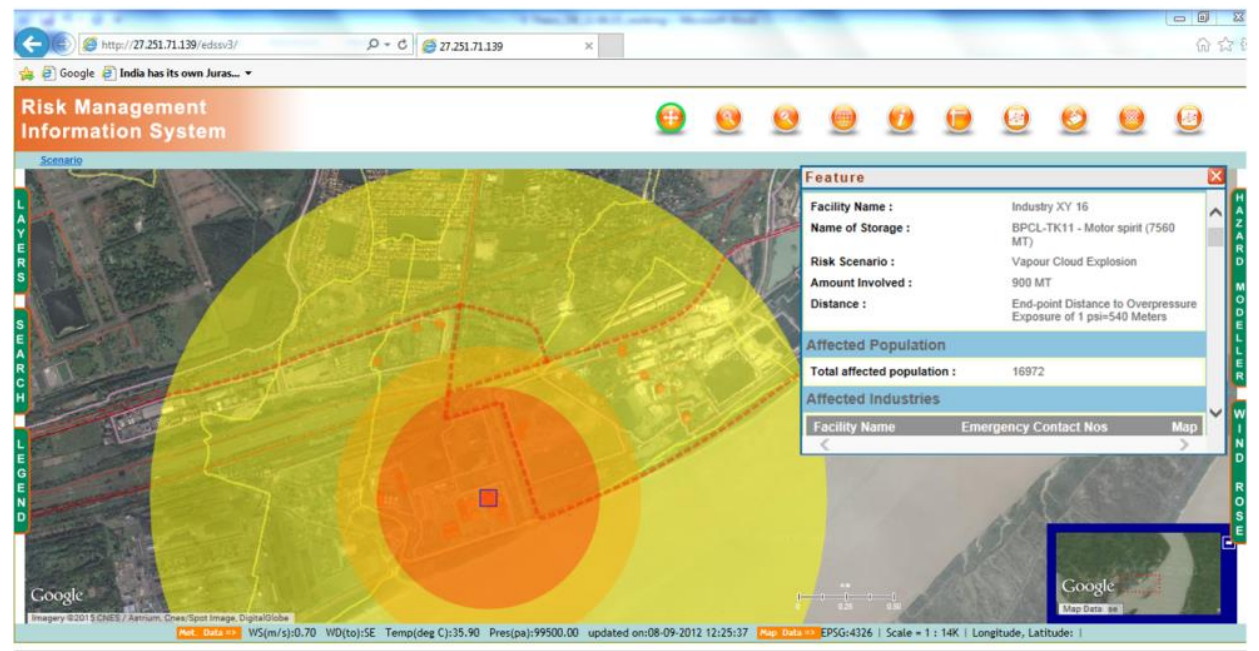

Figure 5-9: Hazard Footprint resulting from VCE at TK11 of Industry XY16.

The ERC swiftly initiates action by directing the on-site emergency team to take measures for controlling the leakage and ensure that probable points of ignition be safeguarded within the site, triggers the offsite response plan by notifying the administration and the industry mutual-aid group to be ready for a potential accident situation. The onsite emergency coordinators of industries which are vulnerable are asked to shut down processes and get into emergency preparedness mode. The local Fire stations are put on alert, but on standby as mobilising fire fighters might also put them at high risk from the explosion's fall out. A radio bulletin is issued to warn people in the Durgachak area to stay indoors or get to the nearest public building and close windows and openings to prevent damages from a blast pressure wave. Phone calls are made to all the vulnerable receptors (schools, hospitals and markets) from the contact information made available from the EDSS. Police are requested to mobilise and stop traffic at major junctions, ahead of the affected stretches of roads.

At 9.10 am, about 30 min after the first notification was made, the sound of an explosion is heard at the Emergency Response Center.

The ERC enquires with the Industry $X Y 16$ and the neighbouring industries to understand the degree of damage caused and to understand potential for 
domino effects. It is reported that 2 other nearby Tanks in Industry XY 16 have caught fire, but there is minimum scope for any further explosions. The ERC mobilises Emergency Response Teams including Fire and Ambulances and starts evacuation procedures for potentially affected population and people who may have been injured. Firefighting teams carrying foam are mobilised to fight the fire in Industry XY 16 to control the situation.

\subsection{Discussion}

The EDSS is expected to be a part of an evolving set of web-enabled decision and planning support systems in India, applicable for different aspects of industrial risk management. The functionalities of the ESDSS provide certain distinct advantages compared to other existing Indian systems and tools for managing industrial emergencies. The key differentiator being that EDSS offers advanced level of decision support capabilities through an online interface to emergency managers including sourcing of significant part of the data requirements from the RMIS database. This allows users a choice and the scope for triggering consequence models through a set of underlying rule bases and providing a visualization of potential damage footprint along with associated information to aid emergency preparedness and response, in the process hiding complexity of input data and modelling tools. Studies have shown this to be one of the reasons for suboptimal use of emergency management systems (Uran et al., 2003). As a result, the tool can provide more credible and robust solution to emergency managers compared to paper based emergency response plans or the GEPR system which can only offer static scenario's based solution with minimum scope for customisation of scenarios (Gahlout et al., 2009).

The SoA based design of EDSS also provides considerable versatility to use to it advantage the convergence of information and communication technologies in the process overcoming one of the key gaps in emergency information systems and tools - interoperability of data maintained by multiple agencies and administrative jurisdictions that are constrained by operational infrastructure to share data (Drummond, 2008; NRC, 2007; Vescoukis et al., 2012). Use of data formats like XML would enable EDSS to share information on model inputs or outputs with other risk analysis tools based on consensus reached on common data exchange format (CDEF) (Binda et al., 2009). In addition, on the geospatial data side, EDSS for example would be able to access vulnerability information made available through the National Spatial Data Infrastructure (NSDI) as WMS/WFS in line with the National Disaster Management Policy of India that stresses on the need for sharing and exchanging disaster management related information through common knowledge platforms (GoI:MoHA, 2009; Singh, 2009). In future, with the ability to access further developments in sensor web services and the 
availability of a host of relevant sensors including UAV based video, chemical leak detectors, portable met stations, etc. which can provide relevant information to respond to an emergency, the EDSS will be able to provide more agile and responsive decision support services to risk actors (Persie et al., 2012; Zlatanova et al., 2012).

At this time, there is scope for improvements of several functionalities of the EDSS. One of the important considerations for EDSS to be functional would be the operationalisation of emergency control room infrastructure. The local or district level Emergency Planning Centre's would then play a central role in establishing coordination and collaboration with experts, local response teams like the police, fire brigade, medical teams, hospitals and civil defence personnel. In spite of the fact that considerable progress has been achieved in India in terms of hardware and network support to run distributed applications on the internet, the failure to obtain data from a central server, due to a link or network failure may withhold decision support during an emergency situation and as a result communication network redundancy needs to be built around the system. Several alternate networking models like the network enabled capability (NEC) (von Lubitz et al., 2008) and the peer-to-peer (P2P) based network (Bortenschlager et al., 2007) may need to be considered for providing more dependable means of networking and communication during emergency situations.

Another critical element of an EDDS that support industrial emergency management decisions would be its ability to predict domino effects. Domino effects in an industrial area are those in which a primary accident becomes the initiating event for other secondary accidents, in the process increasing the severity of consequences of the original accident (Abdolhamidzadeh, 2013; Cozzani, Antonioni, et al., 2006; Reniers et al., 2013). Such domino effects in chemical industries can also be triggered by natural hazards, which are then termed as NATECH incidents (Cozzani et al., 2013). At this time, the EDSS is able to show details of the other storages in the surrounding that would be falling under a hazard footprint resulting from a primary accident. However, it is not yet capable of identifying credible domino scenarios taking into account possible escalation vector based on agreed threshold criteria in combination with spatial analysis (Cozzani, Gubinelli, et al., 2006). As this is an important aspect for decision makers to consider, the 'domino tool' would need further research to be designed and integrated into EDSS. 


\section{Chapter 6- QRA Risk Mapper Tool for Estimating Industrial Risk}

This Chapter discusses the design and development of a web-based tool for estimation, summation and visualization of industrial risk metrics.

\subsection{Introduction}

Evaluation and implementation of risk reduction measures for industrial risk varies considerably in different countries depending on the citizen's perception of the prevailing safety situation, the regulatory approach towards risk assessment and the available methods and tools for tackling the problem (Christou et al., 2000; Pasman et al., 2014). A review of such country-level procedures and practices show considerable diversity in terms of methods for identification of risk scenarios, probability of failures leading to accidents, consequence models used for risk calculation and criteria for risk acceptability (Christou et al., 2011). In countries which are densely populated and with high demand land resources, like the Netherlands and UK, use of Quantitative Risk Assessment (QRA) based methods are preferred in order to determine risk and then compare it to standard risk criteria which then guides land use planning in the vicinity of hazardous installations (BRZO, 1999; HSE, 2011). However, in India, estimation of cumulative risks originating from a cluster of hazardous industries has seldom being undertaken with the intent of implementing risk reduction and land use planning measures. In a national level review pertaining to management of chemical risk, this gap has been attributed to the lack of standardised risk assessment procedures, absence of consistent risk evaluation criteria and the lack of linkage of industry level risk assessment to the planning process (GoI:NDMA, 2007).

Even with the adoption of standardised methods, the calculation of a risk metric (e.g. individual or societal risk) for an area where multiple hazard sources are present is quite complex and requires immense computational support. Such risk estimation efforts need to take into account many possible accident scenarios, requiring processing of large amounts of data, running of mathematical models for determination of consequences that feed into overall calculation for risk, which is then summed up geographically and preferably presented in the form of a risk map for understanding and comprehension of planners and decision makers (Ale, 2002; Basta et al., 2007; Moen et al., 1998; Pietersen et al., 1992). Over the times, since the 1980's, several tools like SAFETI, and later PHAST, RISKCURVES and ARIPAR have been developed and have become widely used tools for risk assessment (Binda et al., 2009; Pasman et al., 2014; Technica, 1984; Van Het Veld et al., 2007). Many of these software tools have achieved a considerable degree 
of coupling with GIS, either for visualization of risk contours on thematic map layers or where the results are exported to other stand-alone tools like ArcGIS with scope for further spatial analysis (Fedra, 1998). However, such software's still presents considerable complexity for users who are not QRA experts (Reniers et al., 2006). In addition, being mostly desktop based applications, the sharing of the outcome of risk assessment to a wider array of stakeholders and consequently arriving at risk mitigation measures through consensus become difficult.

The objective of this Chapter is to conceptualise a Planning Support tool on a distributed architecture for estimating cumulative measures of individual and societal risk using QRA methods. Taking into consideration several chemical hazard sources and multiple risk scenarios, the tool needs to generate a risk map of the area. The risk map can then be used by planners and other riskactors to evaluate area level risk reduction strategies and plans. Based on the conceptualisation, a prototype QRA Risk Mapping tool has been designed and developed which will be demonstrated using case examples from Haldia.

\subsection{Conceptualization}

\subsubsection{Scenario Based Industrial Risk Assessment}

Adoption of appropriate safeguards from risk originating from industrial and natural hazards is considered to be an important component of planning for sustainable development (ISDR, 2004). With increasing number of hazardous industries operating within large industrial clusters in India and a high density of population in neighbouring urban areas, risk actors are often confronted with conflicting interests when judging the suitability of future development proposals and implement measures to reduce industrial risk. The operators of hazardous industries need to adopt methods for identifying and assessing risk originating from their respective units, taking measures to reduce them to acceptable levels. Competent authorities responsible for regulating risk are required to ensure that the risk level portrayed by the industry operator is representative of the actual risk posed and be able to assess cumulative area level risk posed by a cluster of hazardous units. The local government and planning agency needs to have a clear understanding of industrial hazard sources and vulnerability of population in the surroundings in order to adopt appropriate risk reduction measures involving structural measures (e.g. barriers) and non-structural measures like land use planning, early warning, risk communications, etc. The community needs to be convinced about the risk assessment methodology adopted, have a correct understanding of the risk levels to which they are exposed and be in a position to accept the decisions taken by the regulator or planning agency with respect to land use controls and restrictions. 
The adoption of a scientific, rational and standardised approach for estimation of cumulative risk, along with an understanding of risk contributions from individual hazardous industries can provide a strong foundation for evaluating future development proposals (e.g. industry, residential and commercial) and measures for risk reduction for an industrial town (Christou et al., 2000). However, at the same time, the aggregation of risk from several hazard sources is quite complex. For the Haldia area, which has more than hundred such hazard sources, such an assessment can be a complicated affair. The adoption of standardised scenario based explorative approach in Haldia could assist regulators and planners to understand the present risk state and evaluate probable future states that may emerge as a result of implementation of alternate strategies for industrial and residential development (Mahmoud et al., 2009). Based on the scenario alternatives developed, a computerised risk assessment tool can then calculate risks from each identified hazard source, aggregate them over the target area and finally display them through a risk map to guide risk reduction decisions (Ale, 2002; Bottelberghs, 2000).

The development of area level risk scenarios requires considerable amount of information to be consolidated from several sources: location of the hazard source, nature of chemicals stored, physical construction details of storage containers, conditions of storage (pressure, temperature), potential ignition sources, likelihood of an accidental event, nature and typology of the accidental event and its potential consequences. In addition, also required is environmental information including data on meteorological parameters like average wind speed and wind directions, stability class; data on vulnerability including population density and existing community level safeguards like barriers; data on land use in the surrounding area, preferably cadastral level.

In addition, for the application of an area level QRA based risk assessment methodology involving multiple hazard sources, following would also be required:

a standardised process for risk assessment, including methods for defining source specific risk scenarios that will subsequently be aggregated over an area of interest, specification of models for risk calculation, metric and criteria for risk measurement.

- computational resources for performing intensive and iterative calculations to generate multiple risk scenarios, with a user friendly interface for entry of data, integrated modelling tools and knowledge bases, and a map based interface for visualization of risk levels.

integration of spatial analysis tools for calculation of information like area and population under different hazard categories, vulnerability aspects, land ownership, etc. 
- provide visualization of Individual Risk (IR) and Potential Loss of Life (PLL) maps in the area of interest showing different levels of risk (high, moderate, low), based on agreed upon risk acceptance criteria.

- be available on an online platform - can receive inputs from distributed sources; also can communicate planning scenarios to multiple stakeholder / larger audience of risk actors.

Altogether, such a system fits well into the conceptual framework of a distributed Planning Support System and is called the QRA Risk Mapper. The tool is able to generate the existing industrial risk profile of Haldia in terms of IR showing areas that are at high, medium or low risks. A calculation of SR in the terms of Potential Loss of Life (PLL) and its spatial spread can also be presented by the tool so that decision makers can consider priority risk reduction measures where higher population densities are present. In addition, when a risk reduction measure like improvement of safety systems within a plant leading to lower probability of accidents or a reduction in volume of stored chemical is proposed, it's effect in terms of consequent reduction in risk can be clearly evaluated by re-calculating risk levels and assessing the effectiveness of the risk reduction measure. The tool is also able to dynamically generate 'what if' scenarios to evaluate a change in risk profile if new hazardous industries are planned within the area of interest. Similarly, increase in societal risk that may be caused by planning a residential area near to a hazardous industry can also be assessed before the planning authorities take a decision on the proposal. The scenario oriented QRA Framework that will be utilised by the PSS is shown in the Figure 6-1 below. 


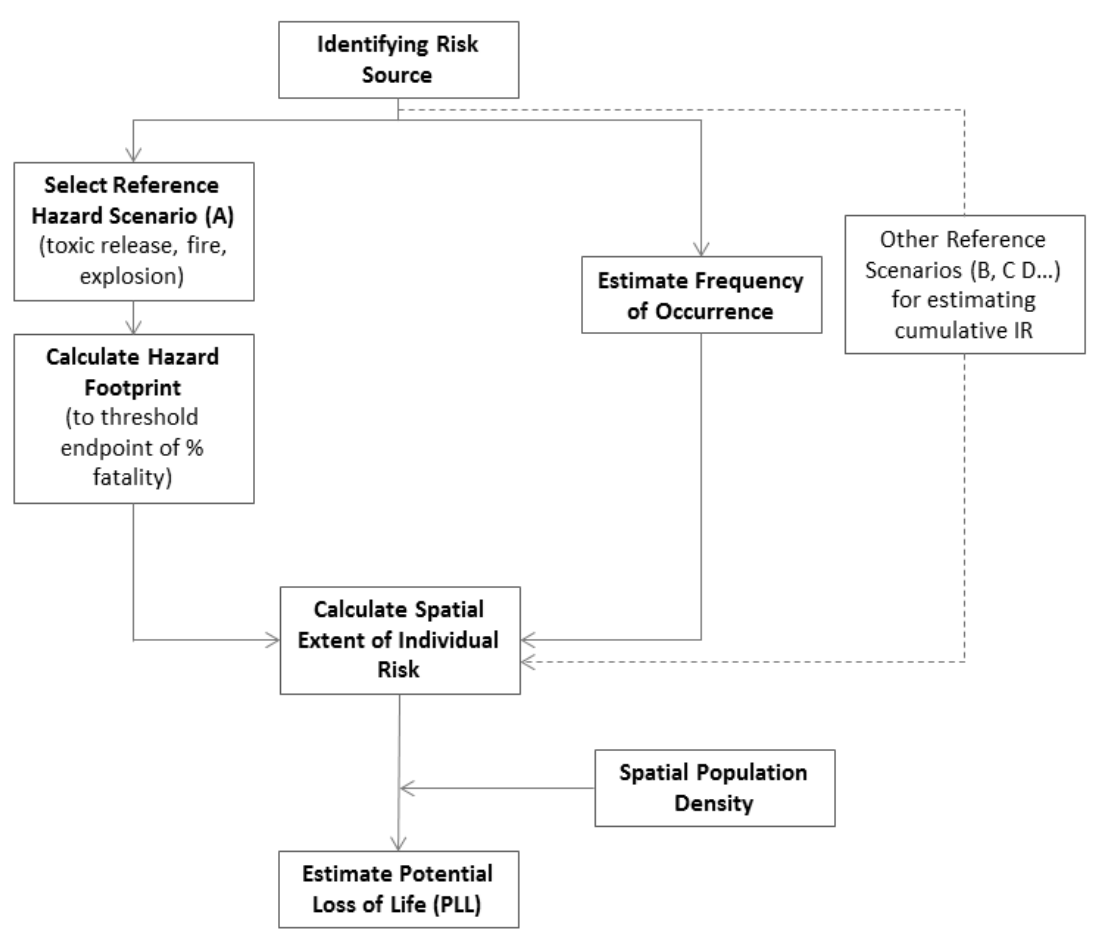

Figure 6-1: QRA Framework for Risk Estimation

\subsubsection{Standardization of QRA Risk Assessment}

For QRA guided risk decision making to be robust and convincing to stakeholders, the adoption of a standardised methodology for risk assessment is central to providing scientifically sound results. The main principles of the methodology should include: consistency of outcomes, which will broadly be the same in similar conditions; proportionality of risk decisions with regard to risk reduction and planning restrictions; transparency in the decision process (Christou et al., 2006). As there is yet no standardised risk assessment procedure laid down through regulatory provisions, the development of the QRA Risk Mapper also provides the opportunity to develop a methodology that can be used by risk actors undertaking risk assessment and using the results for guiding planning decisions.

From a probabilistic point of view, there can be numerous release scenarios that can be associated with a particular storage of hazardous chemical and having different probability of occurrence. Again, based on the environmental conditions, several possible accidental outcomes can develop with varying spread and severity of consequences which can be analysed through an event tree analysis. The following example in Figure 6-2 shows how the estimation 
of frequencies can be made for 4 possible accident outcomes (Jet Fire, Flash Fire, VCE, Tank BLEVE, Road Tanker BLEVE) that may originate from the Full Bore rupture of a pipe through which highly inflammable Propane gas is being loaded from a Storage Tank to a Road Tanker (Casal, 2008).

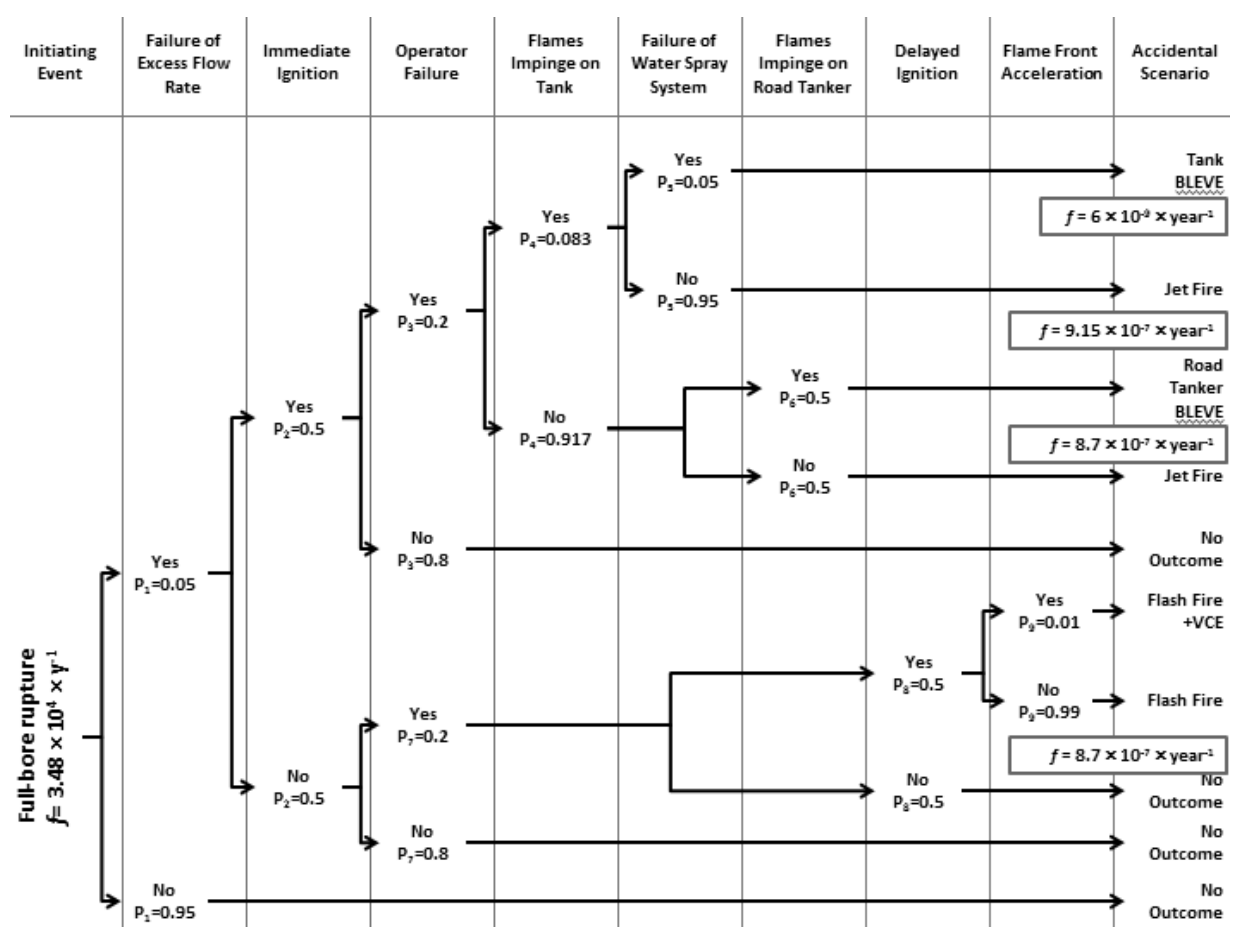

Figure 6-2: Accident Scenarios and Frequency for Full Bore rupture of Propane Pipeline Source: (Casal, 2008)

The selection of accidental event and resulting output in terms of estimated risk would have a significant bearing on the decision for risk reduction or land use planning and several studies have been undertaken to standardise and set reference criteria for their selection (Delvosalle et al., 2006; Fabbri et al., 2009). Various methodologies have been developed through projects like the ARAMIS in Europe (Delvosalle et al., 2005; Salvi et al., 2006; Tugnoli et al., 2013). It is also expected that a standardised methodology will be formulated as a part of the risk assessment process in India including the identification of reference accident scenarios, choice of consequence assessment models and establishment of threshold levels of risk (Christou et al., 2011).

QRA based risk assessment also requires risk assessors and planners to choose and utilise common models for calculation of consequences to be able to estimate risk in a consistent manner. In the present QRA Risk Mapper conception, effects and vulnerability models discussed in standard QRA 
literature has been applied (AIChE/CCPS, 2000; Pe, 2005). Additionally, a set of risk tolerability criteria has to be formulated and agreed upon by regulators and planners, based on which acceptability of risk can be judged and evaluated, once the risk scenario is calculated by the QRA Risk Mapper. In the current implementation, as a test case, the BRZO risk acceptability criteria for the Netherlands have been used for assigning risk levels as 'high', 'moderate' and 'low' (BRZO, 1999).

\subsubsection{Risk Estimation}

Probabilistic QRA methods have been found to be practical for influencing long term planning decisions (Ale, 2002; Christou et al., 2011; Tixier et al., 2006). Different elements of the method have evolved over time and are considered to be based on sound scientific logic in the risk management practice (Baesi et al., 2013; Lees, 1996; Pasman et al., 2014).

In the first step, it is proposed that a standard method for selection of reference accident scenarios be developed based on a benchmarking exercise in Indian hazardous industries and incorporated as a part of the risk assessment procedure for MAH industries in India. Similar studies have been conducted in a number of countries and methodologies like MIMAH for scenario selection delineated (Delvosalle et al., 2005).

In the second step, consequence models have been used to determine the physical effects of an accident to a predefined end-point value, for example the concentration of gas for toxic release, radiation for fire or overpressure for an explosion. Several such algorithms and tools have been discussed extensively in QRA literature (AIChE/CCPS, 2000; Pe, 2005; Uijt de Haag et al., 2005b). The QRA Risk Mapper integrates mathematical algorithms proposed by $\operatorname{AIChE}(2000)$ in order to predict the consequence of toxic gas dispersions, pool fires, boiling liquid expanding vapour explosions (BLEVE), vapour cloud explosions (VCE) - the algorithms for the effect models has been discussed in Chapter 5. Probit functions are commonly used to estimate the number or percentage of fatalities to population exposed to the physical effects of any accident, assuming that the relationship between the logarithmic value of the dose and mortality can be described with a cumulative normal distribution (Casal, 2008). The details of the probit functions that have been used to calculate the endpoints as distances from the hazard source location is presented in the Table 6-1 (Lees, 1996). It must be noted that no specific studies have been undertaken till date to calculate probit values for potential damages in an Indian perspective. 
Table 6-1: Probit Values for Calculation of Accident Impacts

\begin{tabular}{lll}
\hline Vulnerability Vector & Probit Equation & Dose \\
\hline Radiation & $Y=-14.9+2.56 \ln (D)$ & $D=I^{1.33} t_{\mathrm{e}}$ \\
Overpressure & $Y=1.47+1.37 \ln (D)$ & $D=P_{\mathrm{s}}$ \\
Toxic release: Chlorine & $Y=-5.3+0.5 \ln (D)$ & $D=\mathrm{C}^{2.75} t_{\mathrm{e}}$ \\
Toxic release: Ammonia & $Y=-9.82+0.71 \ln (D)$ & $D=\mathrm{C}^{2} t_{\mathrm{e}}$ \\
\hline$Y:$ probit value for fatality; $I:$ radiation intensity, $\mathrm{kW} / \mathrm{m}^{2} ; P_{\mathrm{s}}:$ peak static overpressure, psi; C: Toxic \\
concentration, ppm; $T_{\mathrm{e}}:$ exposure time, min.
\end{tabular}

Finally, in order to plot a risk map, the approach combines the frequency of the initiating event, the conditional probability of the scenario sequence and the probit value of the effect footprint to estimate the Individual Risk (IR) at a particular location $(x, y)$ as per the Equation 6-1 below. The IR represents the probability of death per year of a person at a certain location by combining the likelihood of an accident happening with its predicted physical effect and is represented by an iso-risk map for the area concerned. The resulting cumulative IR at that particular location $(x, y)$ can then be calculated as the sum of the IRs corresponding to several reference scenarios considered for risk estimation as shown in Equation 6-2 and further illustrated in Figure 6-3. The calculation of risk does not however take into account domino effects as it would significantly complicate the estimation of cumulative risk.

where:

$$
\begin{aligned}
& \operatorname{IR}(\mathrm{x}, \mathrm{y}, \mathrm{i})=\mathrm{fi} . \mathrm{PFi} \\
& \operatorname{IR}(\mathrm{x}, \mathrm{y})=\sum \operatorname{IR}(\mathrm{x}, \mathrm{y}, \mathrm{i})
\end{aligned}
$$

- $f_{i}$ is the frequency of the accident scenario i $\left(y^{2} \mathrm{r}^{-1}\right)$; calculated as multiplicative factor of the frequency of the initiating event and the probability that the sequence of events leading to the accident scenario $i$ will occur: $f_{i}=f_{\text {incident } i}$. $P_{\text {sequence } i}$

- $\quad \mathrm{PF}_{\mathrm{i}}$ is the probability of fatality that the accident scenario $\mathrm{i}$ will result at location $x, y$ (i.e. Probit).

- $\operatorname{IR}_{(x, y)}$ is the total individual risk of fatality at the geographical location ( $x$, y)

- IR $(x, y, i)$ is the individual risk at the geographical location $(x, y)$ for a particular reference scenario $\mathrm{i}$

The metric used for societal risk in this approach is defined as the relationship between frequency and the number of people suffering from a specified level of harm in a given population from the realization of specified hazards and represented by the Potential Loss of Life (PLL) as shown through Equation 6-3 (Jonkman et al., 2003).

$$
\operatorname{PLL}(\mathrm{x}, \mathrm{y})=[\operatorname{IR}(\mathrm{x}, \mathrm{y})] * \mathrm{PD}(\mathrm{x}, \mathrm{y})]
$$
Equation 6-3 
where:

- $\quad \operatorname{PLL}(x, y)$ is the Potential Loss of Life at the geographical location $x, y$.

- $\quad \operatorname{IR}_{(x, y)}$ is the individual at location $(x, y)$; and

- $\quad P_{(x, y)}$ is the estimated population density.

SR is calculated by combining the aggregate IR layer with the population grid data, with a certain dimension (Sengupta, Bandyopadhyay, et al., 2015).

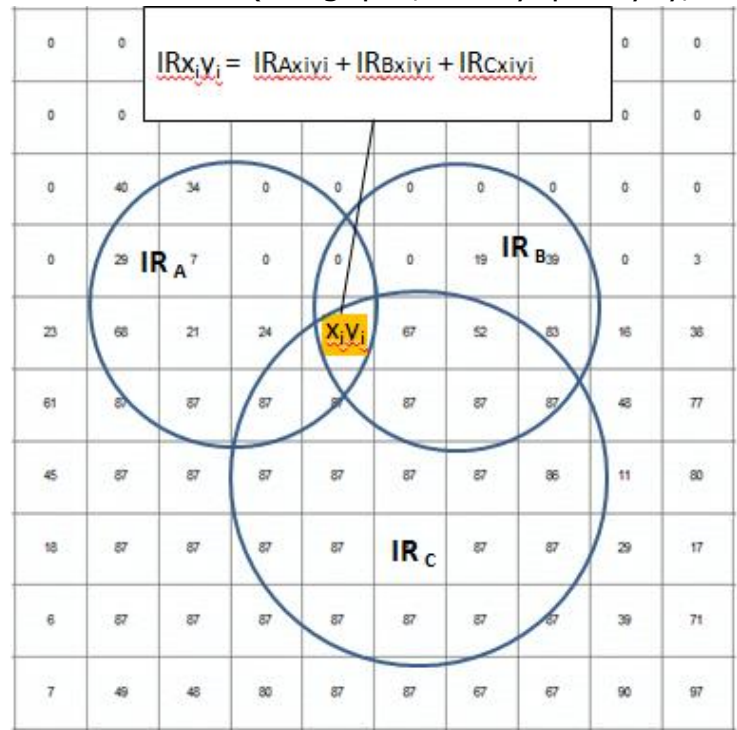

Figure 6-3: Calculation of cumulative IR on a mesh grid

\subsection{Design \& Implementation}

\subsubsection{Information Services}

The calculation of risk resulting from industrial hazards requires information from several sources as mentioned in Section 6.2.1. These include spatial data on the location of potential accident sources, distribution of exposed elements-at-risk and their vulnerabilities and non-spatial data related to chemical properties, chemical quantities, storage conditions and metrological conditions prevailing in the area. The data which is required for running this QRA modelling tool has already been incorporated in the RMIS spatial and non-spatial databases and are housed in a back-end relational database (see Chapter 4).

The QRA Risk Mapper needs to access and process a set of data from the RMIS native database and also a set of information services in the form of WMS and WFS in order to carry out risk calculations and present the required outcomes to the users. This includes: 
- Industry, storage and chemical related data from the RMIS native database;

- Accident scenario database storing scenario wise results of risk assessment undertaken by hazardous industries;

Population grid as a WMS /WFS;

- $\quad$ Cadastre WMS /WFS;

In addition, the system would also be able to import a $\mathrm{xml}$ file containing the details of an accident scenario, as per the 'tags' defined, from other compatible systems.

\subsubsection{Workflow Modelling}

The automation for the dynamic generation of risk maps through a distributed planning support system has been designed based on a logical flow of input parameters, data retrieval from the underlying RDBMS and seamless interactions with the modelling sub-systems, supported by enabling software and hardware platform. Figure 6-4 presents a schematic diagram that explains the process flow, including information requirements from the user, interaction with the modelling sub-system and underlying rule-bases, as well as data retrieval from the geo-database. The process automation has attempted to take into account that the user (who is not expected to be an expert in industrial risk assessment) can provide a minimal set of data in a logical and phased manner to be able to complete the process or import accident scenarios from the RMIS Risk Scenario database where it has been stored as an outcome of industry level risk assessment exercise.

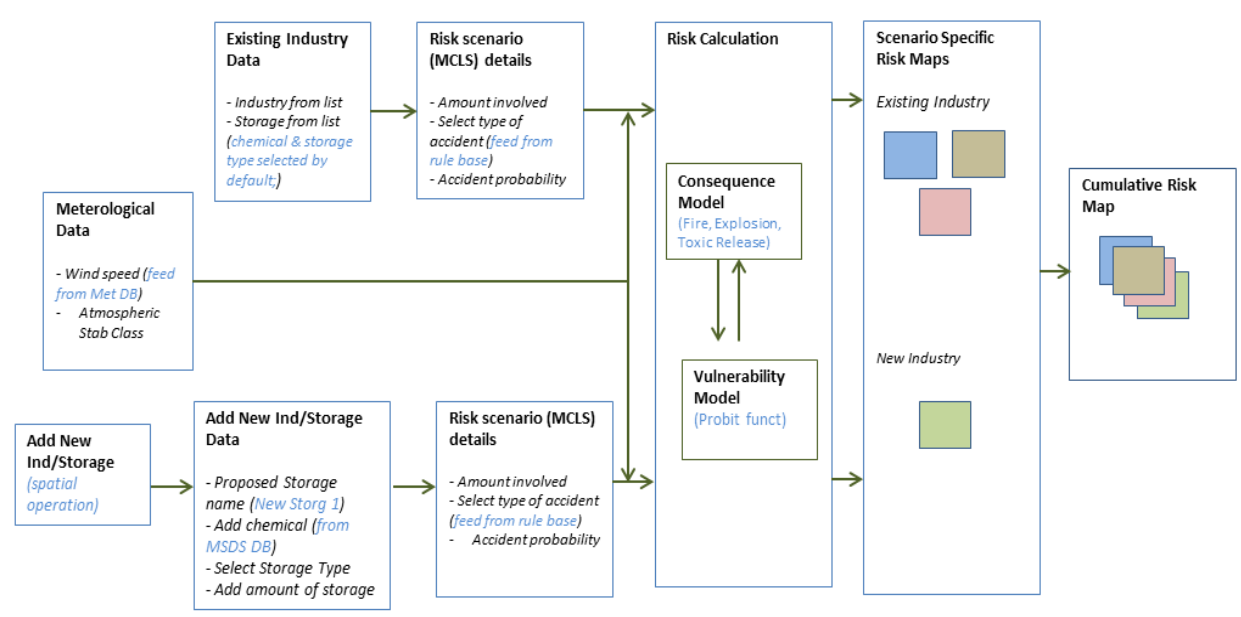

Figure 6-4: Process Automation for Risk Mapping 
The process automation for QRA Risk Mapper has been designed to also allow the user to dynamically create one or more spatial features (e.g. chemical storages) 'on-the-fly', feed relevant attribute data, and generate a risk scenario based on the spatial location of the features that can be added to an existing risk scenario database. The RMIS facilitates the creation of a new hazardous storage facility on the map interface and subsequently model potential risk scenarios. Upon initiation of the functionality, the following steps are followed which is further illustrated in Figure 6-5:

- The user accesses the RMIS map interface to create a dynamic feature by clicking on the desired location on the map. The feature creation request is received by the Map Renderer Object and sent to the Map Engine;

- The request is processed by the Map Engine through a Map Handler Object which in turn captures the spatial location (latitude and longitude) of the point where the user has clicked. In addition, a separate window is displayed to capture the storage name and relevant chemical information from the user;

- The spatial and non-spatial data collected are stored provisionally within the Risk Database tables and a confirmation is sent to the user;

- The Map Engine sends a feature rendering request to the Map Renderer Object for the new feature data captured in earlier steps;

- The Map Renderer object refreshes the existing map and displays the newly created feature through the RMIS map interface;

- The user initiates the Risk Modelling sequence through the Risk Modelling Wizard that is integrated with the RMIS map interface by providing the summary of atmospheric data, selecting the storage and chemical quantity. The modelling wizard implements an internal rule base that guides the user to provide the necessary information required for modelling. The modelling request is received by the Risk Analysis module;

- The Risk Analysis module requests the Risk Database to fetch the storage conditions and the chemical properties for the selected storage. The Risk Database returns the required data to the Hazard Vulnerability Modelling Toolbox which is one of the core components of the Risk Analysis module.

- The Consequence Vulnerability Modelling Toolbox, upon receiving the data, runs the appropriate hazard model and generates hazard footprint end point distances along with vulnerability information;

- Subsequently, the modelling outputs are received by the Map Engine which in turn creates a spatial representation of the hazard footprint using the end-point distances calculated by the model;

- Upon creation of the hazard footprint, the Map Engine sends a feature rendering request to the Map Renderer Object for the hazard footprint created in the earlier step; and 
- The Map Renderer object refreshes the existing map and displays the spatial extent of the hazard footprint along with vulnerability data through the RMIS map interface.

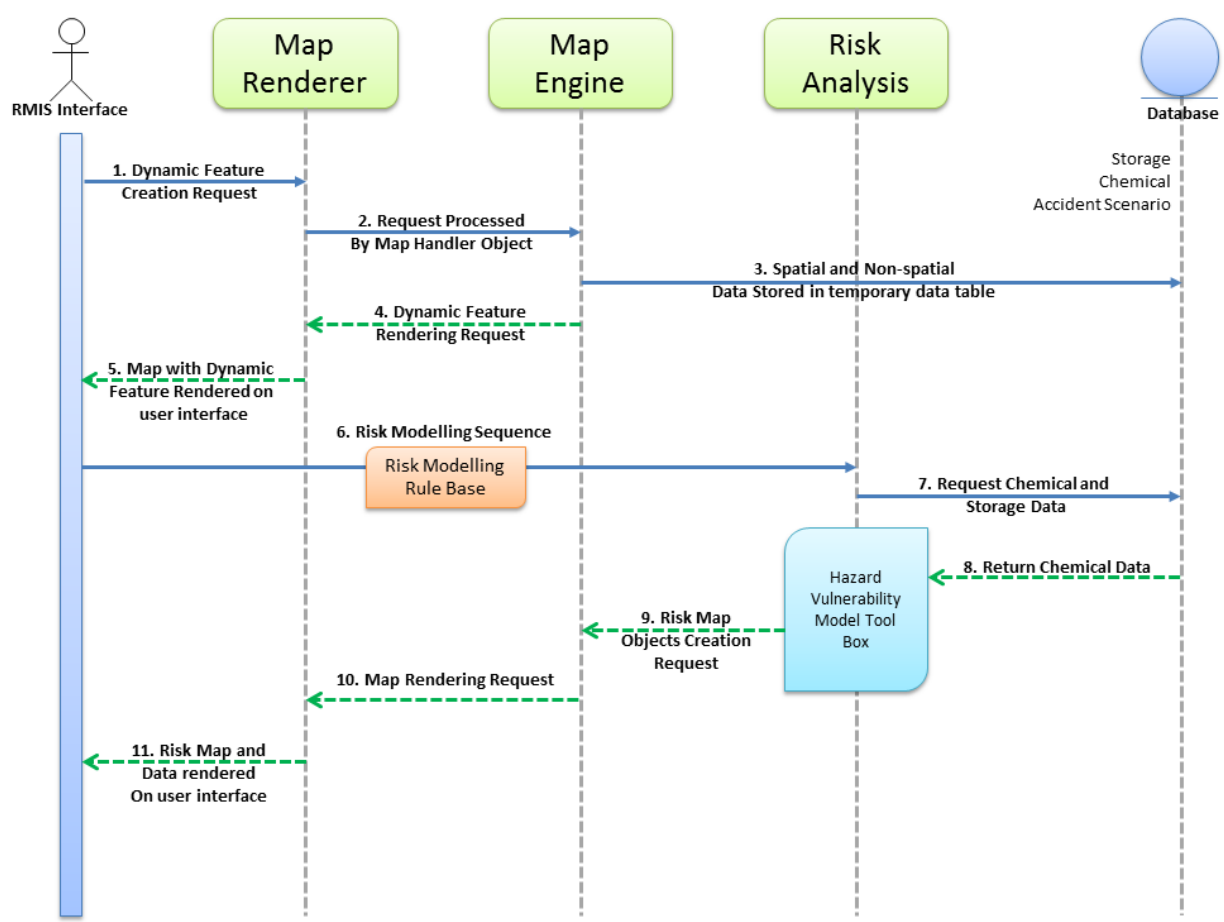

Figure 6-5: Process Flow for Risk Mapping involving a New Spatial Feature

\subsubsection{System Application Architecture}

The QRA Risk Mapper uses the three-layered hierarchical framework of the RMIS platform. The abstract framework is shown in Figure 6-6 and the content of each tier is as follows:

- The data and knowledge tier stores the domain specific information in the SQL Server RDBMS, which can be consumed by the application layer for risk modelling or can directly be used in the presentation layer for providing contextual spatial and attribute information to the user. This includes the storage, chemical, accident scenario databases.

- The application tier contains the rule-based expert system that guides the user through the risk modelling process, the risk modelling algorithms for estimating risk and spatial analysis tools for performing the function of risk calculation and aggregation. The WMS /WFS information services like population density (on a grid) and cadastre are also integrated in this tier from respective context sensitive SDIs. In addition, this tier also uses a map engine component that processes the logic for retrieval of spatial 
and related non-spatial data sets from the geo-database so that it can be used for analysis.

- The presentation tier supports risk mapping and modelling tasks. It comprises QRA Risk Mapper wizard that facilitates the risk mapping process by interacting with the user on one side and the application and data tiers on the other. The web-map graphical user interface in this tier also supports display and querying functions for information related to hazards and vulnerabilities along with the capability to retrieve nonspatial information like data on chemicals or meteorology from linked menu options.

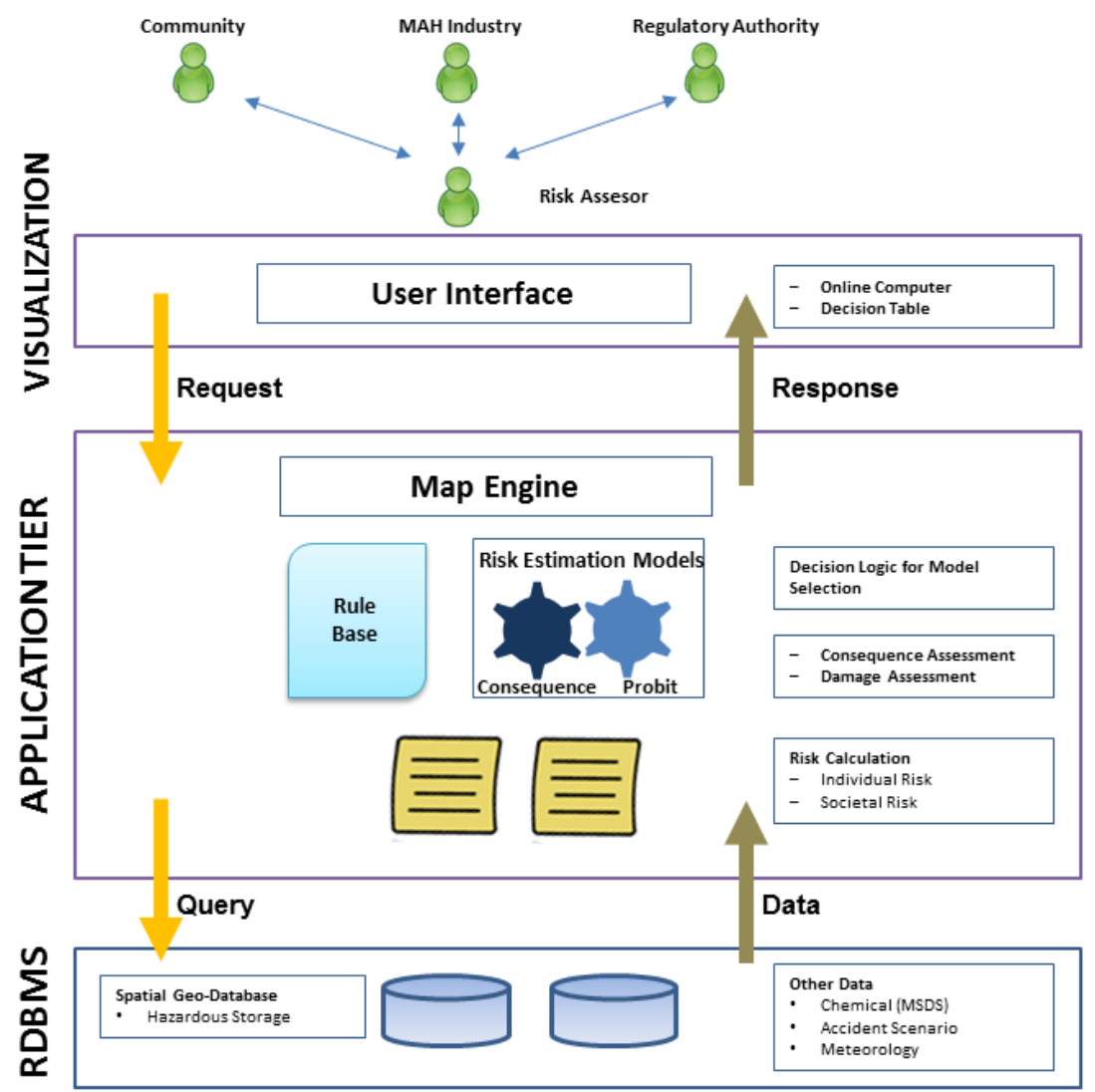

Figure 6-6: Conceptual Framework of RMIS QRA Risk Mapper

\subsubsection{User Interfaces and Visualization}

The system conceptualization planned for an intuitive, user friendly interface with staged information flow and functionalities, based on choices made by the user and complexities being handled through an intelligent analytical system component tied up to models and rule-bases. The QRA Risk Mapper 
module is made available through the custom designed interface of the RMIS. The common features offered to the user include the spatial navigation, information finding and measurement tools on the top part of the interface. The interface and the specific functions are highlighted in the Figure 6-7.

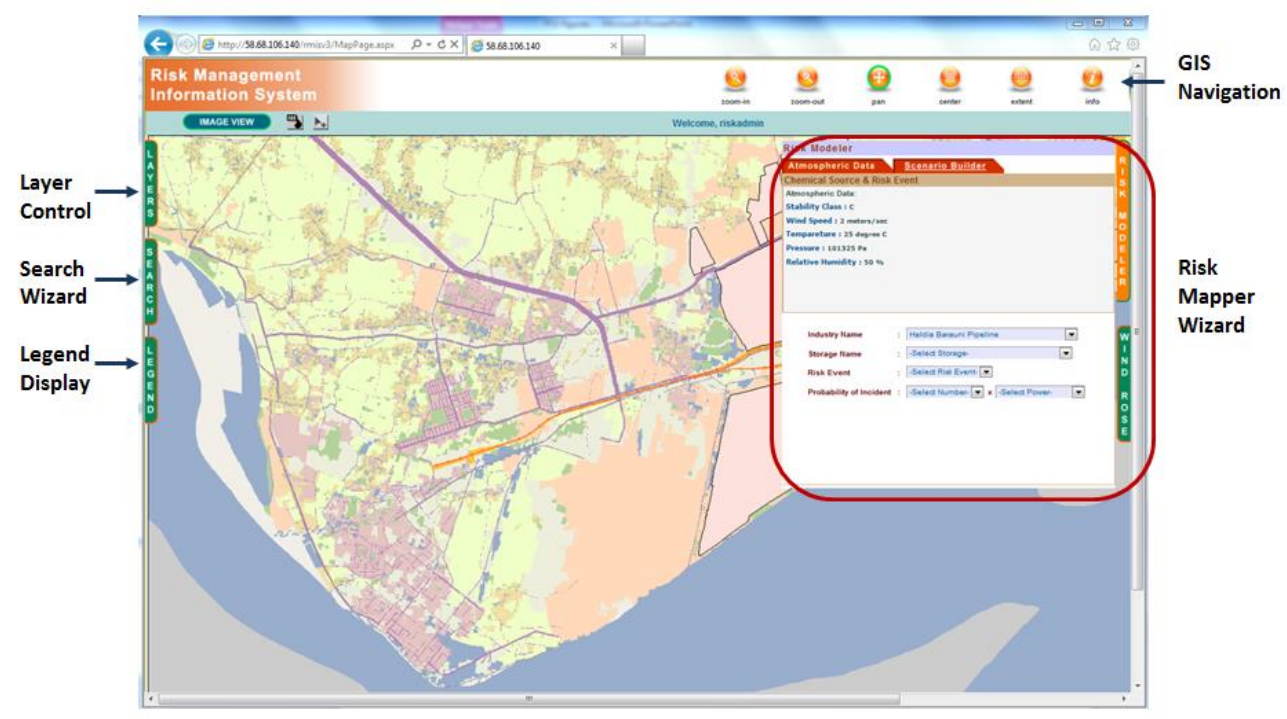

Figure 6-7: RMIS Risk Mapper User Interface

The QRA Risk Mapper wizard interface facilitates two-way communication between the user and the system. On one side, it can manage required user inputs through the interface and on the other, obtain feedback from the RMIS database and show it to the user. It also provides logical and step-wise guidance by interacting with the underlying Rule base in constructing a risk scenario and selecting appropriate hazard and vulnerability models for performing risk estimation. Sequential risk scenarios can be added based on choices made by the user. There is presently no limit to the number of scenarios that can be specified for the generation of the risk map though this aspect has to be decided based on overall guidance from regulatory authorities. At the penultimate step in the wizard (task flow), the user can activate the individual or societal risk mapping functionality. In addition, the user can also select a set of accident scenarios from the Scenario database which can be activated from the wizard through the 'Import Scenario' option, as shown in Figure 6-8. 


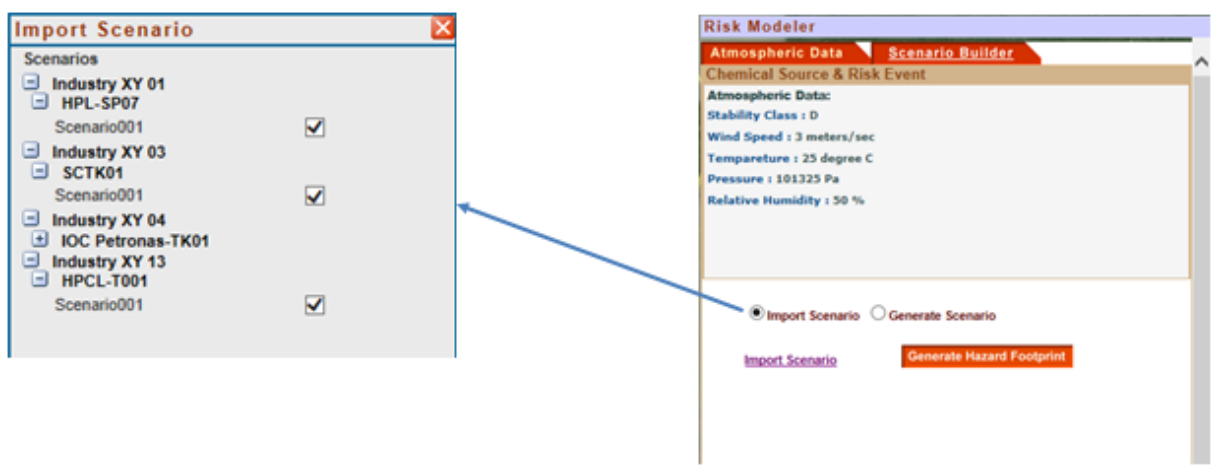

Figure 6-8 : Import Scenario Functionality

In the case of risk associated with a new storage has to be mapped, a separate tool is available to draw up a new point location on the map, where it is being proposed by the user. Sequentially, a new information dialog pops up requesting the user to provide the basic information associated with the new storage viz. storage name, chemical stored, amount of storage and storage conditions. The new feature creation process is shown in Figure 6-9. Once this is done, the new storage is incorporated into the main risk mapper interface making it possible for the user to include it in the risk mapping sequence.

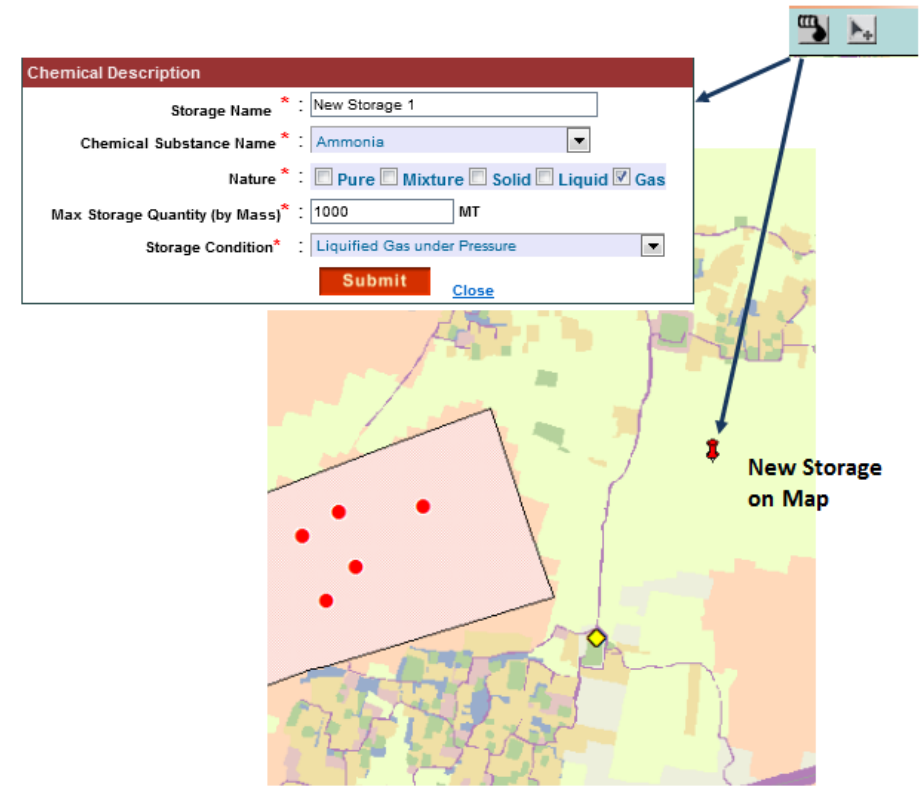

Figure 6-9: Creation of new Spatial Feature and Data Input Dialog 
After this final step is activated, the respective risk map is generated and appears in the map window as a spatial overlay on the land use map or the imagery, whichever is the acting base layer. To provide further information to the user on the interpretation, a pop up window appears giving a brief summary description of the scenarios' chosen, the levels of risk with appropriate legend and more information that the user may be seeking for example: area exposed to a high individual risk level, number of people residing in a high societal risk zone.

\subsection{Demonstration of Prototype Risk Mapper}

In this section, we demonstrate the dynamic risk mapping capabilities of Risk Mapper. In the first instance, the risk mapper is used to generate and visualize cumulative risk maps arising from existing industries, through development of hypothetical, but realistic accident scenarios. This is done based on limited data inputs from the user: meteorology inputs - wind speed and stability class (wind speed guided by meteorological module), accident scenario selection, providing amount of chemicals which are supposed to get involved in a particular accident and the expected probability of the event. The scenarios in Table 6-2 have been used for the calculation and mapping of risk for demonstration purposes. Alternatively, the user can choose from a range of scenarios stored in the Scenario database, as an outcome of an industry level risk assessment process.

Table 6-2: Accident Scenarios for Risk Mapping from selected existing Industries

\begin{tabular}{lllll}
\hline $\begin{array}{l}\text { Risk Source - } \\
\text { Existing } \\
\text { Industry }\end{array}$ & $\begin{array}{l}\text { Chemical } \\
\text { Involved in } \\
\text { Accident }\end{array}$ & $\begin{array}{l}\text { Hazard } \\
\text { Type }\end{array}$ & $\begin{array}{l}\text { Probability } \\
\text { of Event }\end{array}$ & $\begin{array}{l}\text { Amount } \\
\text { involved } \\
\text { (MT*) }\end{array}$ \\
\hline XY13 & HSD & VCE & $3 \times 10^{-4}$ & 3000 \\
XY04 & LPG & BLEVE & $2 \times 10^{-5}$ & 2500 \\
XY03 & Ammonia & $\begin{array}{l}\text { Toxic } \\
\text { Release }\end{array}$ & $5 \times 10^{-5}$ & 400 \\
XY01 & Butene & VCE & $2 \times 10^{-3}$ & 800 \\
\hline
\end{tabular}

*MT - Metric Tonne.

Once the inputs are provided and the individual or social risk mapping function is activated, other associated information that is required for risk estimation models (e.g. physical properties of the chemicals) and a cumulative risk map is rendered on the interface. For the instance of IR estimation, the distribution of risk in the study area is shown under 5 predecided levels of risk - red, orange, yellow and two shades of green. The visualization of the resultant risk map is shown in Figure 6-10. In a pop-up window that is generated, after the model run is completed, the risk levels for each of these zones is specified in a legend and additional information that indicate the probable number of people and the area falling under each 
risk zone is also shown. Based on this information, risk assessor can interact with the stakeholders to arrive at decisions on risk reduction measures high risk zones or land use restrictions for the area of concern.

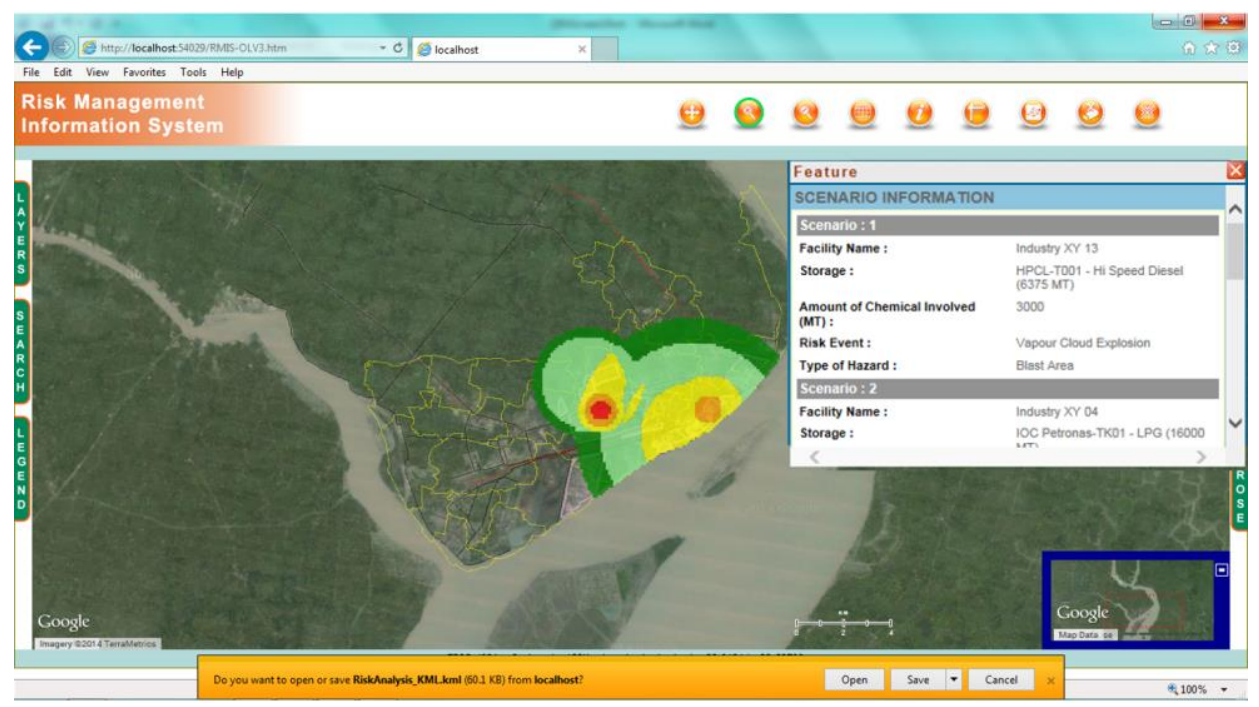

Figure 6-10: Visualization of IR Map for existing Industries (result of 4 scenarios in Table 6.2)

The second demonstration initiates the more dynamic component of the Risk Mapper. We assume that the planner and the stakeholders would like to consider a decision on allowing a new hazardous industry to come up in a proposed location after being reasonably informed of incremental addition of risk in the area through a 'what if' risk scenario analysis. The QRA Risk Mapper provides the user with the functionality to visualize a picture of risk taking into account the setting up of a new hazardous industry. The hypothetical risk scenario is constructed taking into account the earlier base risk scenario (Table 6-2) and then adding to it a proposed industry in the form of a LPG Storage plant, the details of which are provided in Table 6-3.

Table 6-3: Accident Scenario for Newly Created Industry

\begin{tabular}{lllll}
\hline $\begin{array}{l}\text { Risk Source - } \\
\text { New Industry }\end{array}$ & $\begin{array}{l}\text { Chemical } \\
\text { Involved in } \\
\text { Accident }\end{array}$ & $\begin{array}{l}\text { Hazard } \\
\text { Type }\end{array}$ & $\begin{array}{l}\text { Probability } \\
\text { of Event }\end{array}$ & $\begin{array}{l}\text { Amount } \\
\text { involved(MT) }\end{array}$ \\
\hline New Storage & LPG & BLEVE & $3 \times 10^{-5}$ & 400 \\
\hline
\end{tabular}

The user can, on-the-fly, point to the location of the proposed industry or storage using the 'new storage creator' tool, add the required data (as in Table 6-3 above) and follow the earlier set of sequential steps in the risk mapping wizard in order to draw up the cumulative risk levels. The results are returned to the user in the same manner, as earlier, with the system 
spatially incorporating the risk from the new industry. In the case described above, Figure 6-11 shows that levels of IR have resulted in higher risk around the new industry when compared to the previous scenario outcome (Figure 6-10). Based on the industry location chosen and the scenario considered, such an increase in risk may or may not be acceptable to the planning stakeholders and may lead to a decision not to allow the industry at the proposed location and instead try for an alternative location. Any other alternative location can be evaluated in the same manner before an acceptable risk state is reached for a location, where industry can be allowed to be established.

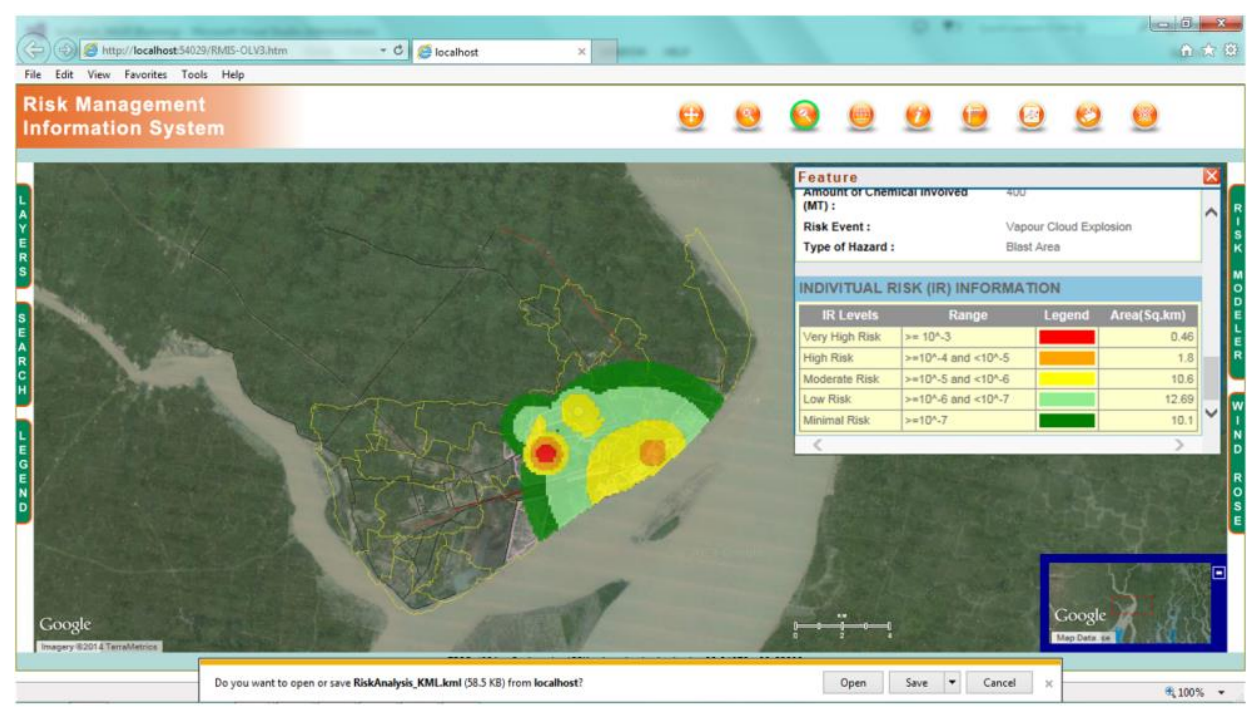

Figure 6-11: Visualization of IR Map for existing \& New Industries (result of combined scenarios of Table 1 \& Table 2 respectively)

In the third demonstration, the risk mapper is used to generate a SR Map in the form of potential loss of life per unit grid area per year. The resulting risk map along with a legend indicating risk levels is shown in Figure 6-12. The societal risk map can be used for identification of specific areas where population density is high resulting in higher vulnerability to a potential risk, than compared to an area where population is sparsely distributed (high density urban to rural). The visualization of SR values can guide the risk actors on selecting priority areas where risk reduction or mitigation plans may need to be focused. Such measures can include the adoption of risk stabilization measures for a settlement falling in the 'red zone', through improvement of housing conditions in an informal settlement, which has developed adjacent to a hazardous industry, contrary to existing land use zoning controls. Alternatively, it can trigger a long-term plan for risk reduction by progressively rehabilitating an existing residential settlement 
(and hence the population at risk) to another safer zone. In addition, there may also be an effort by the stakeholders to improve the coping capacity of population residing in high-risk zones through targeted risk education programs or through organization of safety mock drills.

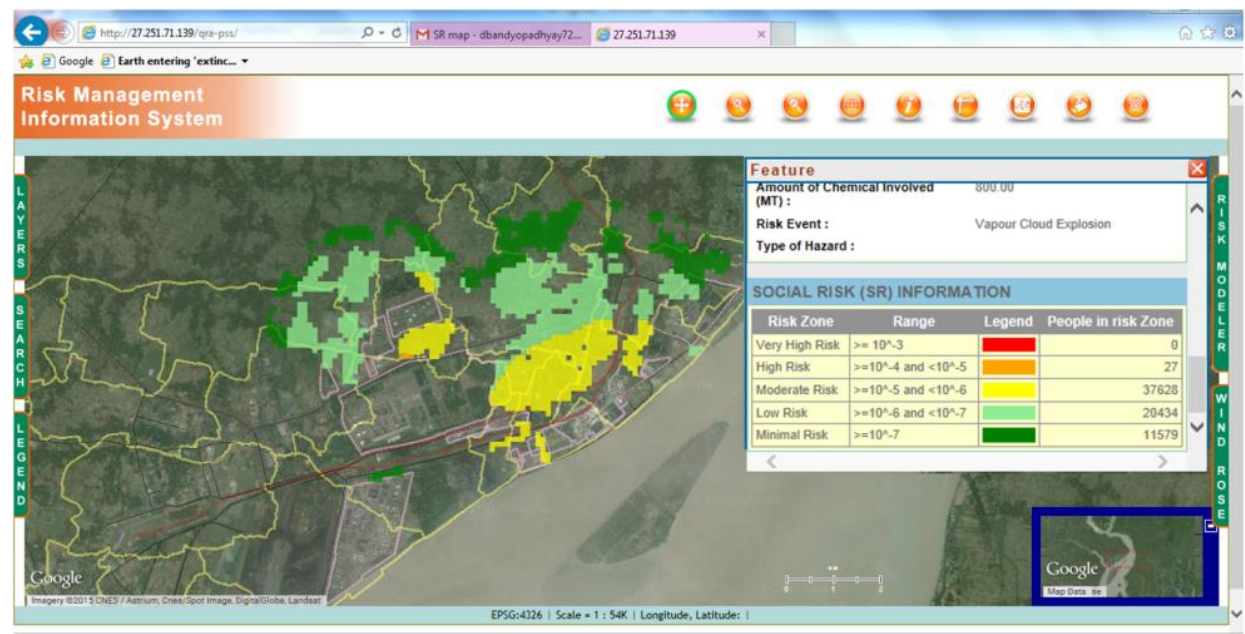

Figure 6-12: Visualization of SR Map for existing Industries (result of 4 scenarios in Table 1)

Figure 6.13 shows the IR map from the risk scenario involving 4 existing industries when viewed through Google Earth, after the output is exported as $\mathrm{kml}$.

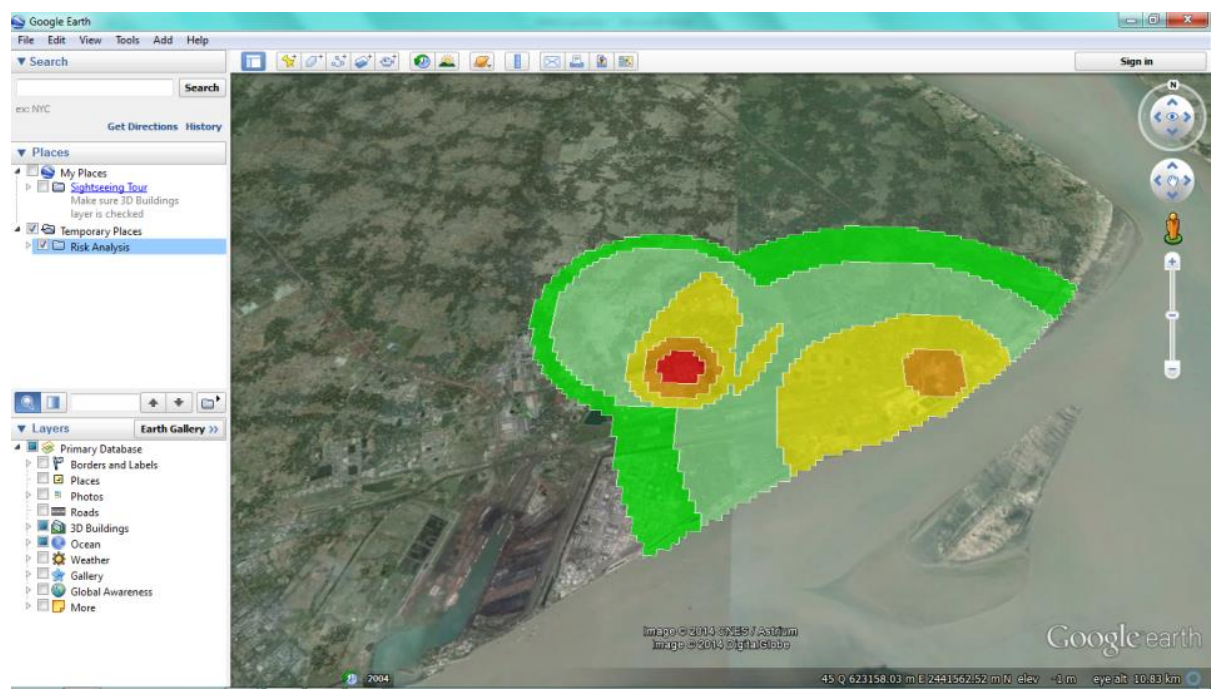

Figure 6-13: IR map, when exported as $\mathrm{kml}$ and viewed through Google Earth 


\subsection{Discussion}

The QRA based Risk mapper tool builds on the foundation of the RMIS in providing a decision and planning support solution to the risk assessment and planning community at the state and local level. The integration of RMIS and Risk Mapper provides the advantages of seamless data exchange, which is a significant requirement for standalone risk assessment tools - being able to source standardised data on hazard sources, chemicals, reference scenarios, etc. is often considered to be one of the key impediments to operationalising harmonised risk assessment procedures (Pasman et al., 2014). In addition, the rule-bases integrated with the Risk Mapper and implemented through a wizard allow risk assessment professionals to follow a pre-set and guided procedure for selection of consequences and models and determining risk levels. The Risk Mapper tool also provides the option of importing input scenarios for running hazard and vulnerability models and also provide visualization based on inputs from other modelling tools that adhere to a preset common data exchange format in the form of XML template files (Binda et al., 2009). For users, who do not have sufficient domain expertise to run the Risk Mapper tool, the risk maps generated by the Risk Mapper can either be saved in the RMIS database for later use or be exported as a $\mathrm{kml}$ file and can be used by stakeholders for visualization of risk map as an overlay on Google Earth.

There is scope for several improvements in the Risk Mapper. The consequence models that are available within the modelling tool box are based on algorithms proposed by the Centre of Chemical Process Safety in the guidelines for Chemical Process QRA (AIChE/CCPS, 2000) and does not take into account complex behaviour of chemicals at the time of release or post-release phenomena like heavy gas dispersions. However, with flexible Service Oriented Architecture, it would be possible to plug-in appropriate models and their modelling sequences through the Risk Mapping wizard. Other future improvements can focus on the incorporation of domino effects in QRA, natural hazards triggered industrial accident scenario's and semiquantitative risk assessment methods to support risk assessment in data scarce situations (Cozzani, Gubinelli, et al., 2006; Reniers et al., 2013). Researches on risk maps as tool for visualizing a distribution of risk over an area of concern also has several uncertainties associated with the lack of validation of prediction results, conditional probabilities or risk events and their treatment and the representation and credibility of risk maps (Zlatanova et al., 2009). These issues are anticipated to come up for resolution once the Risk Mapper tool is implemented and would be dealt with gradually resulting in growing acceptability amongst risk actors with time.

On the risk assessment front, several approaches to risk assessment from hazardous industries currently exist, varying from purely quantitative to 
semi-quantitative and qualitative (Marhavilas et al., 2011). QRA oriented methods which are capable of providing quantifiable measures of risk are considered to be an effective technique to guide longer term risk reduction measures like zoning of land use, provided a systematic methodology for risk assessment has been adopted, resulting in outcomes that are consistent, verifiable and comparable (Christou et al., 2011). Experience in countries practicing QRA based risk assessment has shown that number of factors like selection of reference accident scenarios for a particular hazard source, choice of probabilities of occurring event, endpoints to a particular hazard can lead to a large variation in the results of a QRA (Delvosalle et al., 2006; Fabbri et al., 2009; Kontić et al., 2006; Tugnoli et al., 2013). To respond to this challenge, countries like the Netherlands, UK and USA have laid down detailed guidance for undertaking facility level risk assessments. In the Netherlands, for example, standard metrics have been stipulated through a set of guidance documents called the Coloured Books - Red, Yellow, Green and Purple (Uijt de Haag, 2013; Uijt de Haag et al., 1992, 2005a, 2005b). Some of these countries have gone a step forward by proposing that risk assessment be undertaken using specified software tools like SAFETI NL or ARIPAR (Spadoni et al., 2003; Technica, 1984).

In India, though basic templates for safety audits and emergency management plans are set in regulations, there is no policy or framework document that delineates the risk philosophy to be followed and neither are there detailed procedures that guide regulatory risk assessment. As a result, a review of risk assessment practice for MAH industries points to considerable amount of subjective judgements with regard to selection of accident scenarios, choice of hazard and vulnerability models and their input parameters (e.g. meteorological conditions), consideration of failure probabilities and selection of risk acceptability criteria (ERM, 2002; GoI:NDMA, 2007). Under these circumstances, there is a distinct opportunity to choose the online RMIS platform and the Risk Mapper Tool for introducing a harmonised risk assessment process in the country. The use of the RMIS would provide an opportunity for competent regulatory authorities to streamline and standardise the facility specific risk assessments on one side and on the other provide a method for aggregation of risk at an area level, with the provision for measuring the risk contribution of individual facilities. The picture of area level cumulated risk can then provide a much needed input to land use planners in an industrial town to be able to set appropriate zoning restrictions and for regulators to considering approvals for new facilities that plan to locate in the area. Of course, the institutionalisation of such a tool has to be preceded by a benchmarking exercise leading to the formulation of guidelines for selection of reference accident scenario's, setting up of frequency databases, laying down details of risk assessment models and specifying risk acceptability criteria. 


\section{Chapter 7 - PSS for Risk Guided LU Planning}

This Chapter discusses the design and development of a distributed multicriteria evaluation based tool for undertaking risk guided land use planning for an industrial area.

\subsection{Introduction}

Management of land resources through appropriate planning measures and tools has been widely recognised to be a shared basis for sustainability and risk reduction (ISDR, 2004). Land use planning, involves particular processes to evaluate and decide upon different options for the use of land, can provide an useful approach for managing population growth, ensuring environmental sustainability and managing risks in urban areas (FAO, 1996). In emerging economies experiencing fast paced industrialisation and urbanisation, divergent and often conflicting development objectives coupled with population growth, increasing migration to urbanised areas, informal economies, weak regulatory frameworks, as well as conflicting social and cultural values attributed to the use of land pose significant challenges for planners to factor risk into land use planning (Christou et al., 2000; Linkov et al., 2005; Salvi et al., 2006).

Recent trends in decision making involving environmental and risk issues indicate a paradigm shift from technically focused, functional rationality approach involving objective assessments undertaken by experts to a communicative rationality approach that accords major emphasis on issues of societal concerns and their resolution (Eduljee, 2000; Khakee, 1998; Renn). This relatively newer approach, when applied to industrial risk management, would incorporate the perspectives and knowledge of stakeholders through a constructive engagement process to arrive at a decision within a specific socio-political framework and consequently having a higher chance of success - a trend which has been termed as the democratizing of risk management (McDaniels et al., 1999; Renn, 1999; Stern et al., 1996). The adoption of such participative approaches in risk management is expected to lead to the emergence of new governance networks that will be no longer limited to regulators and industries, but would become more inclusive, and involve a more transparent sharing of information with stakeholders in order to build their involvement in the decision making process (Gouldson, 2004). However, with the issue of risk often presenting a complex and multifaceted problem set involving divergent views amongst different stakeholders, behavioural research shows that individuals on their own may often encounter difficulty in making informed and thoughtful choices (McDaniels et al., 1999). Under such circumstances, group decision processes may often emerge more successful 
with the involvement of shared resources and broader constituencies, being better placed to deal with uncertainties and value trade-offs (Herrera-Viedma et al., 2002). Group decision processes, assisted by decision support tools, may help group members to specify differences and similarities among alternative options and resolve conflicts through the adoption of deliberative mechanisms (Armstrong, 1993).

Multi-criteria Analysis (MCA) has evolved into a promising technique for solving complex environmental and risk related planning problems requiring trade-offs between socio-political, environmental and economic impacts and which are often difficult to quantify in objective terms (Kiker et al., 2005). MCA can act as a versatile tool for structuring of a decision problem involving multiple stakeholders and help in exploring of concerns and preferences of actors involved in the decision making process (Beinat et al., 1998). MCA methods coupled with GIS has been found to be particularly of high interest amongst the decision support community for its utility in solving spatial problems involving siting issues and the allocation of land for optimal purposes (Malczewski, 2006). Several such MCE techniques in combination with GIS like MCE-RISK and Land Use Planning and Chemical Sites (LUPACS) have been applied for developing interactive tools that are capable of undertaking assessment of value trade-offs and support choice of decisions with regard to risk based land use patterns problems (Chen et al., 2001; Papazoglou et al., 2000). However, most of these earlier systems were desktop based and prevented open collaboration between stakeholders taking part in the decision making process.

Since early this century, there has been significant progress in the use of web-GIS based planning tools that leverage the power and flexibility offered by the distributed architecture to deliver spatial planning support, hiding the complexity of decision models and algorithms while making it more accessible to planners and interested stakeholders (Bhargava et al., 2007; Sugumaran et al., 2007). Such systems, as compared to traditional desktop based systems facilitate group understanding through collaborative planning processes in addition to providing assistance to data management, analytical problem solving, decision making and communication (Nedović-Budić, 1998). This is leading to specific planning support systems with GIS being coupled with decision analysis tools like multi-criteria evaluation, and can be operated through a unified thin-client interface, gaining popularity (Malczewski, 2006). However, there have been few tools implemented that allow for obtaining stakeholder opinions for spatial planning, through a web-enabled spatial multi-criteria oriented tool that is supportive of the deliberative dimension of decision making i.e. does not restrict collaboration by time or location of participants (Boroushaki et al., 2010a; Rinner et al., 2009). 
The objective if this Chapter is to conceptualise a collaborative Spatial MultiCriteria Evaluation (SMCE) based planning support system called SMCE Planner on a distributed architecture to assist stakeholders in risk mapping using qualitative methods in India. The SMCE Planner tool will be capable of accepting stakeholder choices for undertaking risk guided land use suitability analysis in order to guide land use planning decisions. The conception of the SMCE Planner PSS accounts for modalities to enable participation of groups and stakeholders to select a planning goal, choose criteria, assign preferential weights and undertake SMCE in order to generate alternative scenarios and visualize the outcome as risk or suitability maps through an online tool. These output maps can then support a deliberative and consensus oriented approach to risk guided spatial planning decisions. A prototype SMCE Planner PSS has been designed and developed and is demonstrated with few hypothetical case examples for Haldia.

\subsection{Conceptualization}

\subsubsection{Collaborative PSS Framework}

In this section, we present a framework for a web-based collaborative planning support system for dealing with two kinds of industrial risk management related tasks - risk mapping and risk guided land use suitability analysis. We propose a MCE based decision making framework which is particularly suited to factor in user preferences and choices in decision making, involving a number of aspects. SMCE has been applied for solving numerous environmental decision problems, but given the strong technical focus that is involved in the practice of industrial risk assessment, not many SMCE based approaches are documented to solve problems associated with industrial risk. In addition, with most of SMCE methods being based on raster data and consequently needing significant data processing, web based SMCE applications are few.

The first objective relates to multi-criteria risk mapping and does not in general compare different decision alternatives, but undertakes an assessment of an area or region with respect to the prevailing level of risk and its spatial distribution (Carpignano et al., 2009). The risk mapping component of the SMCE Planner Tool is based on choice of a set of industrial risk indicators and the weightage given to them by the stakeholders through deliberations, resulting in the generation of a composite risk map that portrays a normative view of the distribution of risk in the area. The stakeholders, individually or in groups can take part in the risk mapping process through the web-based SMCE Planner Tool, complementing a process of risk estimation which is presently undertaken by experts and often based only on a technical understanding of risk. This methodology and toolset will 
also provide the scope for producing multi-hazard risk maps, combining the risks of several hazards that a particular study area may be susceptible to.

The second objective pertains to analysing land use suitability with a particular goal - finding land for a new residential estate or an industry, taking into account multiple criteria based on which preference for such new development would be decided. For several planning goals, alternative scenarios can be generated by an individual or stakeholder group based on selection of a criteria set and the preference accorded to them resulting in a suitability map. If such evaluation is done for multiple objectives (industry and residential), there may be potential conflicts between the decision spaces, which then may need to be managed through conflict resolution methods in a consensual manner; however, multiple objective evaluation is not part of the present research objective.

The system conceptualization takes into account the spatial multi-criteria evaluation assessment process starting from goals setting to the generation of the outcome maps following an analytical-deliberative process. The analytic-deliberative process generally includes a suite of analytical tools working in tandem with consultation mechanisms involving stakeholder groups - scientists, administrative official, planners and affected communities (Renn, 1999; Stern et al., 1996). This means that with the inputs of scientifically derived spatial indicators and agreed upon multi-criteria based decision analysis process, stakeholders will discuss and negotiate on the identification of concerns and the priority given to each of them, deliberate on differences and resolve conflicts, to attain the suitability map after a number of iterations. The resulting map can then be used to take planning decisions like imposing restrictions on residential properties coming up in high-risk areas or allocating land for setting up of more hazardous industries. The conceptual framework of the system is shown in Figure 7-1. 


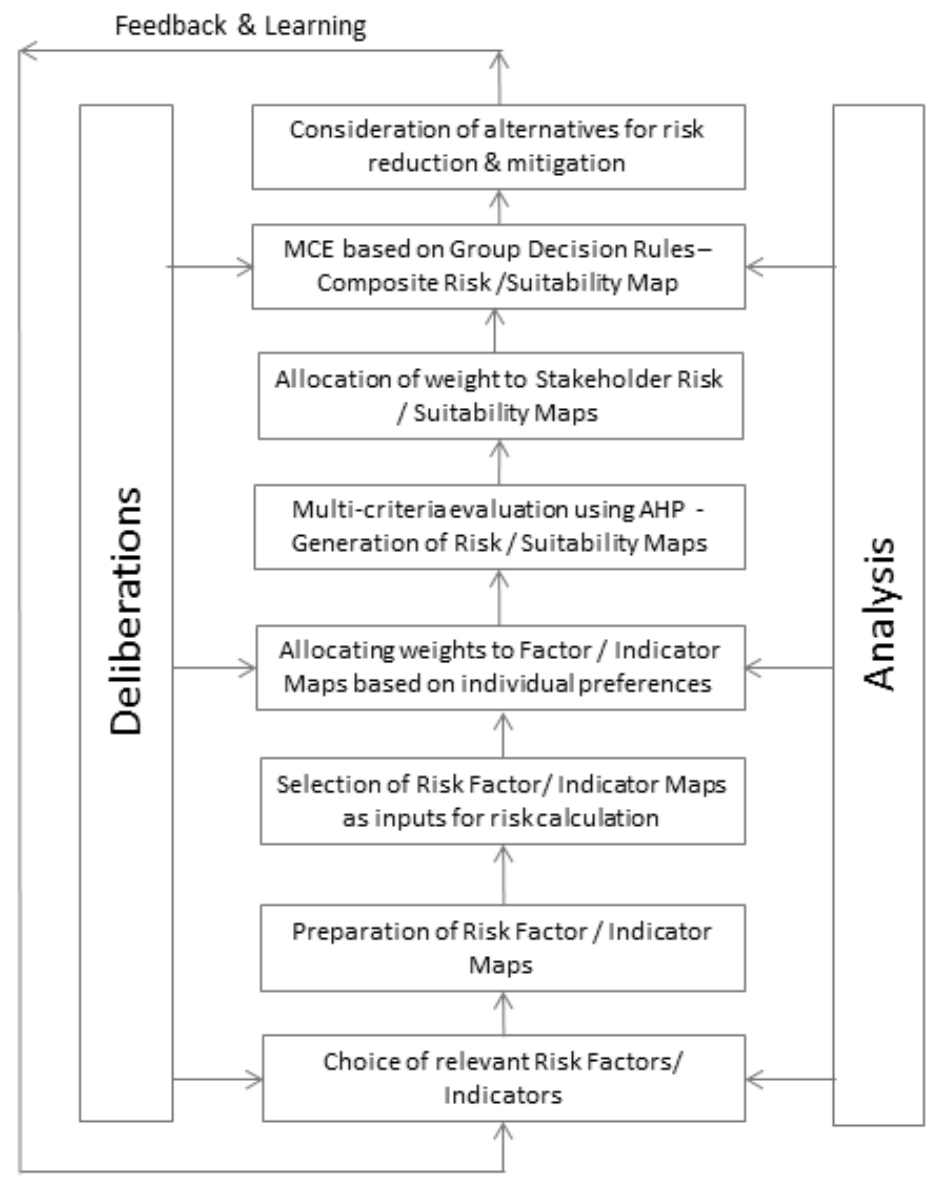

Figure 7-1: Conceptual Framework for developing Risk \& Suitability Maps using MCE

Figure 7-2 presents a use-case diagram for undertaking risk guided land use zoning with the participation of risk actors. It presents several interrelated use cases and actors who play critical roles at different stages. The process begins with the hazardous industries undertaking industry level risk assessment through hazard scenario definition, hazard modelling and determining elements at risk. The hazard scenarios along with accidental event probabilities, defined by the industries, can be modelled for calculation of individual risk based on standard functions set by the regulators. Coupled with population vulnerability, a measure of social risk could also be derived and spatially portrayed as PLL. The societal risk distribution along with other planning indices could then be used by a spatial planner, in a participatory manner, together with other stakeholders (administration, land revenue department and the community) to generate suitability maps and lay down risk guided zoning plans. 


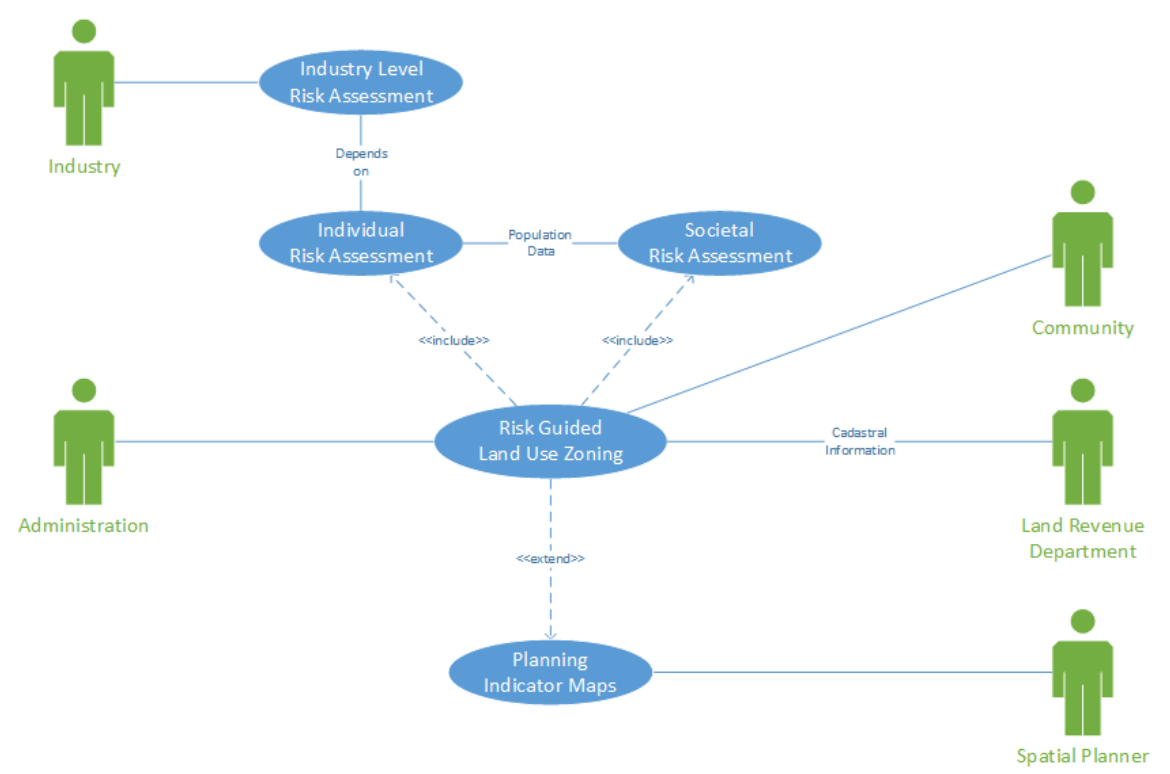

Figure 7-2 : Use Case Diagram for Risk Guided Land Use Zoning

\subsubsection{MCE Approach and Methodology}

Based on these two problem sets, the design of the SMCE Planner Toolbox is undertaken so that it can undertake an evaluation of spatial alternatives based on the adoption of a suitable SMCE methodology. Both the problem sets fit a finite decision field comprising of a set of alternatives that can be evaluated to arrive at a possible best alternative and can be described by the Multi-Attribute Decision Making (MADM) approach. The SMCE process that would finally result in a composite risk map or a suitability map to be created can be described through the following steps:

1. Selection of a set of objectives that is reflective of the concerns related to the risk decision problem and specification of measures through which they can be measured. In our case, the first objective would be to estimate the distribution of risk in the area of interest taking into account the dimensions of hazard, exposure and coping capacity. Example is to be able to identify areas that are at high risk based on consideration of several factors. The second objective is to arrive at a suitable area for developing new hazardous industries and/ or residential areas, taking into account risk based concerns, other planning considerations and constraints.

2. The criteria to be used in the evaluation have to be identified and measured. The selected criteria should reflect the concerns specific to the risk decision problem and should be measureable (Greiving et al., 2006). Though several criteria's that can be formulated, they should not be too 
many, while providing a sound basis for decision support. In addition, the set of criteria should also be flexible to choose with a scope for rearrangement during the process of generation of alternatives. Several methods for identifying relevant criteria exists, but from the participative point of view, stakeholder groups should play a role in identifying criteria they think should be applicable. Group discussion and deliberation using Delphi techniques are often adopted to identify and evaluate the criteria / indicators (Malczewski, 1999). The measure of the criteria should also be standardized to provide for uniform scale in the data set so that they are comparable. Several methods are available for such standardization and for the objectives set, linear normalization of the criteria has been adopted with the scale varying between 0 to 1 .

3. Assigning of weights to the criteria, including the risk criteria and other ones, showing their relative importance or preference relative to others. The weight determines the degree of influence of a particular criterion in the overall evaluation and is crucial to the outcome generated through the aggregation process. In a group decision environment, the weights of the individual criteria are determined through subjective assessments as a part of deliberations and negotiations within the group. Several methods are available for assigning weight to the criteria. Simpler techniques involve ones like the point sum allocation that allow stakeholders to specify the relative importance of criteria on an interval scale. Other more complex techniques like AHP involve the comparison of each criteria to all the others regarding their relative importance (Saaty, 1979).

4. Several decision rules are available as a part of SMCE methods for aggregation of criteria and arriving at a final decision map. Weighted Linear Combination (WLC), also called the Simple Additive Weighting (SAW), is considered to be simple to apply and matches the requirement of spatial aggregation for a spatial multi-criteria evaluation. Using WLC, several indicator map layers can be aggregated by multiplying each criteria map with the corresponding weight and then summing the products over all the criteria.

The SMCE process for the SMCE Planner Toolbox, as conceptualised using the steps above, is shown in Figure 7-2. The parent matrix contains the criteria in one axis $\left(C_{1}\right.$ to $\left.C_{n}\right)$, and a list of possible scenario alternatives, from which a decision has to be taken on the other axis $\left(S_{1}\right.$ to $\left.S_{m}\right)$. Each cell in the matrix $\left(\mathrm{s}_{\mathrm{ij}}\right)$ indicates the performance of a particular alternative in terms of a particular criterion. The value of each cell in the matrix is composed of the multiplication of the standardised value of the criterion for the particular scenario, multiplied by the weight $\left(W_{1}\right.$ to $\left.W_{n}\right)$ related to the criterion. Once the matrix has been filled, the final value can be obtained by adding up all cell values of the different criteria for the particular alternative (e.g. $a_{11}$ to $a_{1 n}$ 
for alternative $A_{1}$ ). Using this method, a composite risk or suitability map can be generated using one or two levels of multi-criteria analysis. These vector values are rendered at the user end through the map engine in a standardized colour scheme, following a risk gradation index that is intrinsically set within the SMCE toolbox and overlaid on a base map of the study area.
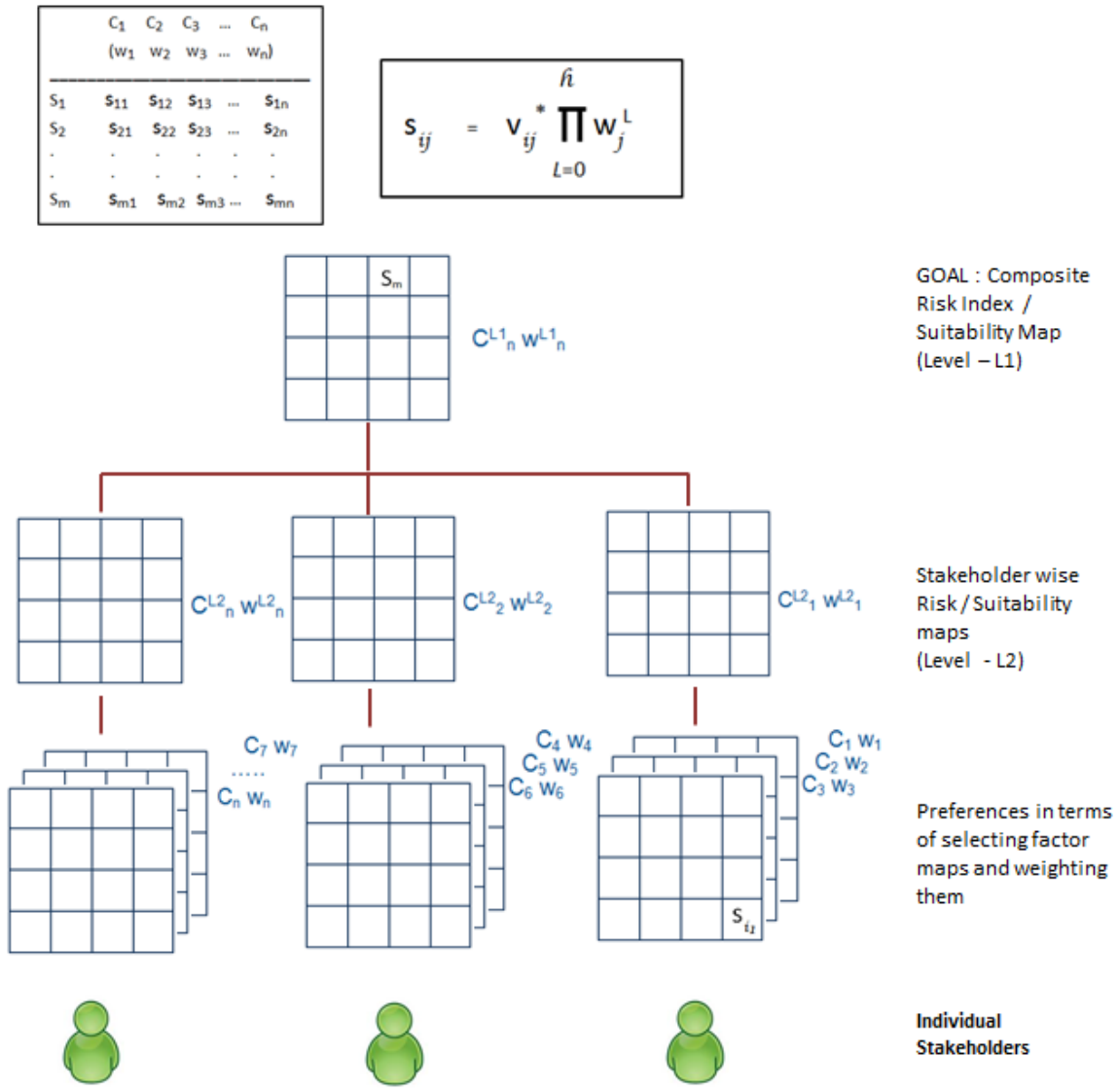

Figure 7-3: Schematic representation of SMCE process for SMCE Planner Toolbox

\subsubsection{Risk \& Planning Indicators}

A spatially oriented approach to risk management and risk guided land use planning would require the consolidation of relevant spatial data and convert them into information and knowledge. The process of formulation of spatial indicators is considered a robust and tested approach to guide this process of risk guided spatial planning (Grønberg, 1999). A review of literature shows several efforts to develop indicators of risk, hazard and vulnerability at the local and regional levels. Based on the indicator sets, several risk indices like the UNDP's Disaster Risk Index (DRI) and the Community Based Risk Index 
has been formulated (Birkmann, 2007). Most of the approaches involved in developing risk based indicators theorise risk to be comprised of three major dimensions: the hazard potential which combines the probability of the hazard with its severity; vulnerability to a hazard; and exposure (Greiving et al., 2006). According to the stakeholder's appreciation of the industrial risk problem, along with the aspect of the hazard map derived through QRA based methods, several aspects of vulnerability of the exposed area like human health, economic conditions, culture, education and other related factors can be considered (Birkmann, 2007; Christou et al., 2000; Papazoglou et al., 2000). The methods utilised to develop such indicators vary, but most of them are data driven and based on data sets that are generally available in public domain. Another key aspect of such indicator development approaches is to measure the indicators relevant to each dimension of risk in a quantitative way so that they can be compared with different areas and for communities (Cardona, 2004). The choice of indicators should be undertaken in a careful manner so that it facilitates consensus building, duly providing importance to the aims and priorities of the respective stakeholders (Greiving et al., 2006).

The knowledge building process involving the conversion of hard data to subjective indicators can be undertaken through the application of several methods involving map algebra, boolean operations, interpolation techniques, spatial modelling. Some examples are spatial constraints, spatial distribution oriented aspects like population density measured on a grid through interpolation of Census data, information derived through modelling like hazard potential and distance based spatial criteria. In this research though, it is not within our objective to get into the task of choosing robust indicators or laying down a procedure for indicator development. Rather the focus on developing an online tool, which can, using a set of demonstrative spatial indicators, representing various dimension of hazard and vulnerability, can aggregate them through an iterative and flexible process based on the choice and preferences of the concerned stakeholders to formulate a risk or suitability map of the study area. The proposed indicator based risk assessment methodology process is shown in Figure 7-3. 


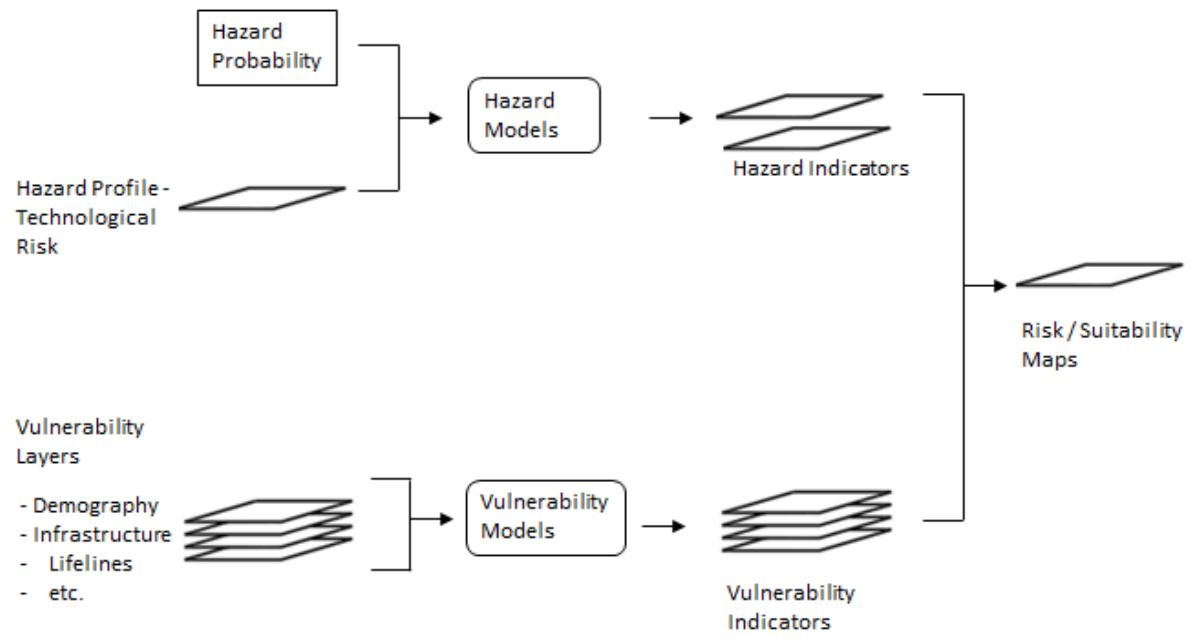

Figure 7-4: Indicator based planning support process to be implemented through MCSDSS

\subsection{Design \& Implementation}

\subsubsection{PSS Design and Analysis Workshop}

The conceptualisation of the SMCE Planner tool was undertaken in a way that the stakeholders and risk actors would find it beneficial for risk mapping and land use suitability analysis, following an analytical-deliberative process. In order to understand the information needs and planning / decision making requirements from such a system that proposes the collaborative use of maps through multi-actor planning process, a design and analysis workshop was held in Haldia in December, 2011. From the collaborative mapping point of view (Carton et al., 2009), the key objectives of the 2-day workshop were:

- improve stakeholder understanding and promote exchange of local level knowledge on industrial risk, vulnerability and associated planning issues in Haldia;

- identify stakeholder objectives with regard to risk reduction and acceptability;

- communicate information on spatial distribution of industrial risk and evince feedback on suitability of land uses in Haldia;

About 25 individuals having a stake in the planning process participated in the workshop. This included regulators, planners, experts in industrial risk, industry and mutual-aid group representatives, local administration, community groups, residential associations and NGOs, representatives from local schools and hospitals. In the first day of the workshop, several sessions were held to provide stakeholders with an appraisal of the risk and 
vulnerability situation prevailing in Haldia. The perspective of land use planning and its challenges and constraints that may come in way of the future growth of the area was also presented to the participants by local planners as well as experts who were part of the panel. Extensive use of maps was made to develop a spatial understanding of hazards, vulnerabilities and other planning factors in the workshop.

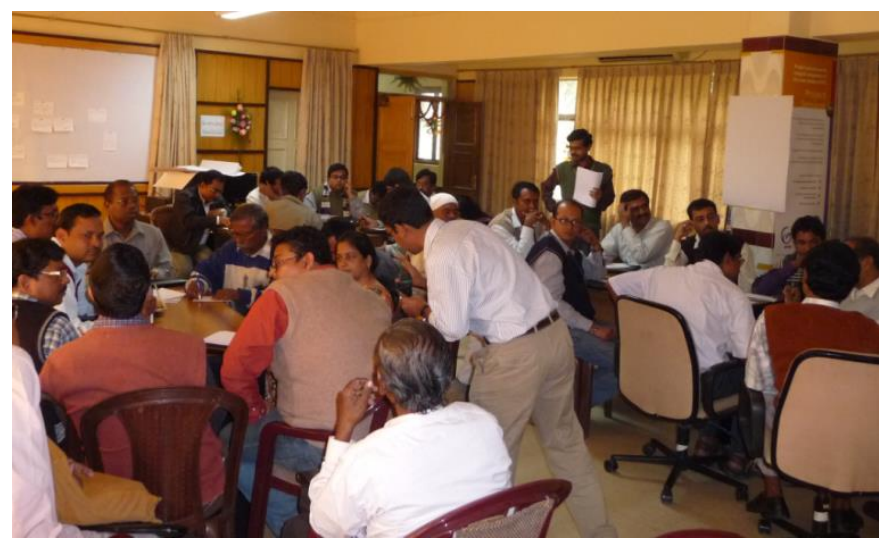

Photo 7-1: Stakeholder Planning Workshop in Haldia

On the second day, the workshop was opened up for interactions and collaborative sessions between participants. The participants were divided into 4 groups and each group had in minimum a representative from the key stakeholder groups: industry, community groups, regulators and planners. Assisted by maps of the area, the groups were requested to identify spatial criteria that they thought were important for arriving at suitability for new residential or industrial area. In addition, they were given the task of identifying spatial factors that need to be accounted for in land use planning undertaken with the goal of ensuring the safety of citizens. Subsequently, they were also asked to indicate group wise preference for the criteria's shortlisted by each of the groups.

At the end, the feedback of the stakeholders was taken to understand their requirements in terms of planning support from computerised tools. The following were the key recommendations that emerged from the workshop:

- Preparation of a consistent set of risk and planning indicator maps which can assist in participatory decision making on the contentious issue of land use planning in Haldia;

- Formulation of a flexible and adaptive decision making process based on normative methods like SMCE through which the stakeholder preferences for the factors selected for planning can be expressed. 
- Development of a tool with simple intuitive interfaces that would allow stakeholder planning preferences to be expressed and through which the outcome can be visualized in the form of a risk or suitability map.

\subsubsection{Data \& Indicator Preparation}

Based on the feedback from the workshop, a set of spatial indicators were mapped using desktop GIS tools. All the indicator maps were prepared on a uniform vector mesh that represented the study area as a grid of equally sized square cells of $100 * 100 \mathrm{~m}$, in the same frame that was earlier used in the RMIS for the interpolated population grid. This resulted in uniformity of the indicator maps and enables the application of a SMCE decision rule to aggregate cells in multiple layers leading to calculation of a net score for each grid cell and an outcome decision map. The indicator map layers are stored in the RMIS RDBMS as a knowledge base.

The following techniques were used for formulating the spatial indicators:

- Modelled indicators: based on application of modelling algorithms which for example, calculate the level of a hazard or evacuation vulnerability.

- Spatial analysis and map algebra based indicators: based on calculation of buffer distances, density metrics, boolean operators and interpolation techniques.

The indicators have been standardized on a scale of 1-4 based on perceptions of risk obtained from various stakeholders through Delphi method with the higher value (4) representing a lower risk or higher suitability. A list of indicators prepared, along with associated standardisation information is presented in the Table 7-1.

Table 7-1: Risk and Planning Indicators for SMCE

\begin{tabular}{|c|c|c|c|c|}
\hline \multirow[b]{2}{*}{ Indicator } & \multirow{2}{*}{$\begin{array}{l}\text { Standardisation } \\
\text { Technique }\end{array}$} & \multicolumn{3}{|c|}{ Standardisation } \\
\hline & & Range & $\begin{array}{l}\text { Assigned } \\
\text { value }\end{array}$ & Area \\
\hline \multicolumn{5}{|c|}{ Spatial analysis } \\
\hline Distance to & Linear & $0-100 \mathrm{~m}$ & 1 & \\
\hline Habitation & $\begin{array}{l}\text { Standardisation } \\
\text { (LS) - higher the } \\
\text { distance, higher } \\
\text { the score }\end{array}$ & $\begin{array}{l}100-250 \\
m \\
250-500 \\
m \\
>500 m\end{array}$ & $\begin{array}{l}2 \\
3 \\
4\end{array}$ & \\
\hline
\end{tabular}




\begin{tabular}{|c|c|c|c|c|}
\hline \multirow[b]{2}{*}{ Indicator } & \multirow[b]{2}{*}{$\begin{array}{l}\text { Standardisation } \\
\text { Technique }\end{array}$} & \multicolumn{2}{|c|}{ Standardisation } & \multirow[b]{2}{*}{$\begin{array}{l}\text { Indicator Map of Study } \\
\text { Area }\end{array}$} \\
\hline & & $\begin{array}{l}\text { Score } \\
\text { Range }\end{array}$ & $\begin{array}{l}\text { Assigned } \\
\text { value }\end{array}$ & \\
\hline $\begin{array}{l}\text { Distance to } \\
\text { Industry }\end{array}$ & $\begin{array}{l}\text { LS - higher the } \\
\text { distance, higher } \\
\text { the score }\end{array}$ & $\begin{array}{l}0-500 \mathrm{~m} \\
500 \mathrm{~m}-1 \\
\mathrm{~km} \\
1-2 \mathrm{~km} \\
>2 \mathrm{~km}\end{array}$ & $\begin{array}{l}1 \\
2 \\
3 \\
4\end{array}$ & \\
\hline $\begin{array}{l}\text { Distance to } \\
\text { Commercial }\end{array}$ & $\begin{array}{l}\text { LS - higher the } \\
\text { distance, higher } \\
\text { the score }\end{array}$ & $\begin{array}{l}0-500 \mathrm{~m} \\
500 \mathrm{~m}-1 \\
\mathrm{~km} \\
1-2 \mathrm{~km} \\
>2 \mathrm{~km}\end{array}$ & $\begin{array}{l}1 \\
2 \\
3 \\
4\end{array}$ & \\
\hline $\begin{array}{l}\text { Distance to } \\
\text { Port }\end{array}$ & $\begin{array}{l}\text { LS - higher the } \\
\text { distance, higher } \\
\text { the score }\end{array}$ & $\begin{array}{l}0-500 \mathrm{~m} \\
500 \mathrm{~m}-1 \\
\mathrm{~km} \\
1-2 \mathrm{~km} \\
>2 \mathrm{~km}\end{array}$ & $\begin{array}{l}1 \\
2 \\
3 \\
4\end{array}$ & \\
\hline $\begin{array}{l}\text { Distance to } \\
\text { Railway } \\
\text { Station }\end{array}$ & $\begin{array}{l}\text { LS - higher the } \\
\text { distance, higher } \\
\text { the score }\end{array}$ & $\begin{array}{l}0-500 \mathrm{~m} \\
500 \mathrm{~m}-1 \\
\mathrm{~km} \\
1-2 \mathrm{~km} \\
>2 \mathrm{~km}\end{array}$ & $\begin{array}{l}1 \\
2 \\
3 \\
4\end{array}$ & \\
\hline $\begin{array}{l}\text { Distance to } \\
\text { Highway }\end{array}$ & $\begin{array}{l}\text { LS - higher the } \\
\text { distance, higher } \\
\text { the score }\end{array}$ & $\begin{array}{l}0-500 \mathrm{~m} \\
500 \mathrm{~m}-1 \\
\mathrm{~km} \\
1-2 \mathrm{~km} \\
>2 \mathrm{~km}\end{array}$ & $\begin{array}{l}1 \\
2 \\
3 \\
4\end{array}$ & \\
\hline
\end{tabular}

\begin{tabular}{llll}
\hline Distance to & LS - higher the & $0<1 \mathrm{~km}$ & 1 \\
Hospitals/ & distance, higher & $1-3 \mathrm{~km}$ & 2 \\
Health & the score & $3-5 \mathrm{~km}$ & 3 \\
Centres & & $>5 \mathrm{~km}$ & 4
\end{tabular}

Coastal Regulation Zone
Area under CRZ is Boolean 0 constrained for development
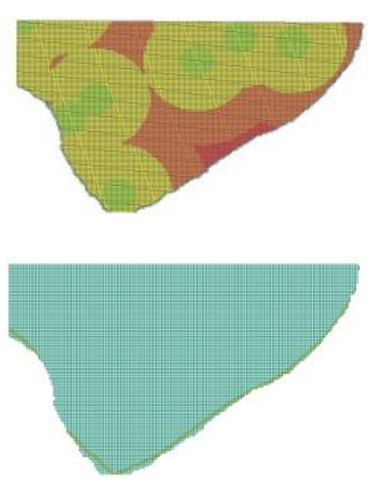


\begin{tabular}{|c|c|c|c|c|}
\hline \multirow{2}{*}{ Indicator } & \multirow{2}{*}{$\begin{array}{l}\text { Standardisation } \\
\text { Technique }\end{array}$} & \multicolumn{2}{|c|}{$\begin{array}{l}\text { Standardisation } \\
\text { score }\end{array}$} & \multirow{2}{*}{$\begin{array}{l}\text { Indicator Map of Study } \\
\text { Area }\end{array}$} \\
\hline & & Range & $\begin{array}{l}\text { Assigned } \\
\text { value }\end{array}$ & \\
\hline $\begin{array}{l}\text { Flood prone } \\
\text { area }\end{array}$ & $\begin{array}{l}\text { Area under CRZ is } \\
\text { constrained for } \\
\text { development }\end{array}$ & Boolean & $\begin{array}{l}0 \\
1\end{array}$ & \\
\hline \multicolumn{5}{|c|}{ Modelling \& Data Mining } \\
\hline $\begin{array}{l}\text { Individual } \\
\text { Risk (IR) }\end{array}$ & $\begin{array}{l}\text { LS - higher the } \\
\text { risk, higher the } \\
\text { score }\end{array}$ & $\begin{array}{l}>1 \times 10^{-7} \\
>1 \times 10^{-6} \\
>1 \times 10^{-5} \\
>1 \times 10^{-4}\end{array}$ & $\begin{array}{l}1 \\
2 \\
3 \\
4\end{array}$ & \\
\hline $\begin{array}{l}\text { Population } \\
\text { Density }\end{array}$ & $\begin{array}{l}\text { LS- higher the } \\
\text { population, higher } \\
\text { the score }\end{array}$ & $\begin{array}{l}1-24 / \\
\text { hect } \\
25-79 / \\
\text { hect } \\
79-150 / \\
\text { hect } \\
>=150 / \\
\text { hect }\end{array}$ & $\begin{array}{l}1 \\
2 \\
3\end{array}$ & \\
\hline $\begin{array}{l}\text { Evacuation } \\
\text { Vulnerability }{ }^{1}\end{array}$ & $\begin{array}{l}\text { LS - higher the } \\
\text { Evacuation } \\
\text { Vulnerability, } \\
\text { higher the score }\end{array}$ & $\begin{array}{l}>3000 \\
2000- \\
3000 \\
1000- \\
2000 \\
<1000\end{array}$ & $\begin{array}{l}1 \\
2 \\
3 \\
4\end{array}$ & \\
\hline
\end{tabular}

\subsubsection{SMCE Modelling Toolbox and Application Architecture}

The system architecture which has been designed to operationalize the conceptual architecture of the SMCE Modeller is based on a Tool Box approach (Malczewski, 1999). The core of the system comprises of a SMCE Toolbox comprising of two key modules. The first comprises of a collection of preference modelling techniques which are structured based on multi-criteria decision methods and are capable of generating the hierarchical structure for evaluation and aggregation of criteria weights. The aggregation criteria can subsequently be applied on a set of individual indicator maps as delineated in the conceptual framework. To allow for treatment and analysis by the SMCE Toolbox, weighted scores are calculated based on the first level of computation undertaken at the web client side through encrypted java script code. The SMCE calculations for criteria weighing can be done using three methods: point allocation, rank-sum, and AHP. The algorithms presented in Table 7-2 support the calculation of weights for each method. 
Table 7-2: SMCE Criteria Weighting Algorithms

\begin{tabular}{|c|c|}
\hline Method & Algorithm \\
\hline Point Allocation & $\begin{array}{l}\text { Weights are estimated by giving a point to each criterion on a } \\
\text { normalised scale of } 1-5 \text {, which is then normalised on a scale } \\
\text { of } 1 \text {. }\end{array}$ \\
\hline \multirow[t]{2}{*}{$\begin{array}{l}\text { Rank Sum } \\
\text { (Malczewski, 1999) }\end{array}$} & $w_{j}=\frac{n-r_{j}+1}{\sum_{k}\left(n-r_{k}+1\right)}$ \\
\hline & $\begin{array}{l}\text { Rank sum, where normalized weight } w_{j} \text { of the } j^{\text {th }} \text { criteria, } n \text { is } \\
\text { number of criteria and } r_{j} \text { is the rank position of the criterion. }\end{array}$ \\
\hline \multirow[t]{3}{*}{$\begin{array}{l}\text { AHP } \\
\text { (Saaty, 1979) }\end{array}$} & $\begin{array}{l}\text { Consistency Ratio (CR) = Consistency Index (CI) / Random } \\
\text { Consistency Index (RI) }\end{array}$ \\
\hline & $\begin{array}{l}\mathrm{CI}=\left(\lambda_{\max }-n\right) / n-1 \ldots \ldots \ldots \ldots . . \text { Eqn. } 7.2 \\
\lambda_{\max } \text { is the principal Eigen Value; } n \text { is the number of factors }\end{array}$ \\
\hline & $\begin{array}{l}\lambda_{\max }=\Sigma \text { of the products between each element of the priority } \\
\text { vector and column totals. }\end{array}$ \\
\hline
\end{tabular}

The second key module of the system is the decision model for multi-criteria evaluation. The system works on WLC method where the overall value of a cell $\mathrm{Sij}$ is calculated by summing up the weighted value for each criterion for a certain alternative ' $i$ '.

$$
\mathrm{S}_{\mathrm{ij}}=\sum \mathrm{c}_{\mathrm{ij}} * \mathrm{w}_{\mathrm{j}} \quad \text {-......... Eqn. } 7.3
$$

Where, $c_{i j}$ is the value of a cell for the alternative ' $i$ ' for the weight ' $j$ ' and $w_{j}$ is the standardised weight of criterion $\mathrm{j}$.

The SMCE modelling toolbox is integrated with a Data Management Toolbox which consolidates the data on each indicator set based on analysis of spatial and non-spatial data and stores it in the RMIS RDBMS as a vector grid layer, checks for consistency and standardisation as per a pre-defined range and makes the indicator set available as spatial criteria for SMCE. The Data Management Toolbox also allows for storing of the SMCE outcomes as a vector data layer for later access and further analysis.

The SMCE Modeller functions on the three-layered hierarchical architecture of the RMIS platform. The abstracted form of the architecture is shown in Figure 7-5 and the content of each tier is as follows:

- The lowermost level is a knowledge base comprising of a set of indicators, which are derived based on analysis from the datasets present in the relational database. Design principles takes into account that relevant indicators are represented on a common vector grid template and is based on analysis of spatial and non-spatial data of the region. 
- The application tier contains the SMCE toolbox which comprises of a set of algorithms for assigning normalized weights to indicators, selected as criteria for SMCE. It also contains the SMCE decision model based on which the weighted criteria or indicator layers are evaluated.

- The presentation tier supports normative risk mapping and suitability analysis tasks. It comprises SMCE Modeller wizard that facilitates the SMCE process through 3 logical steps. The web-map graphical user interface in this tier supports the generation of the outcome of the SMCE as a map layer, showing different levels of risk or suitability, depending on the goal.

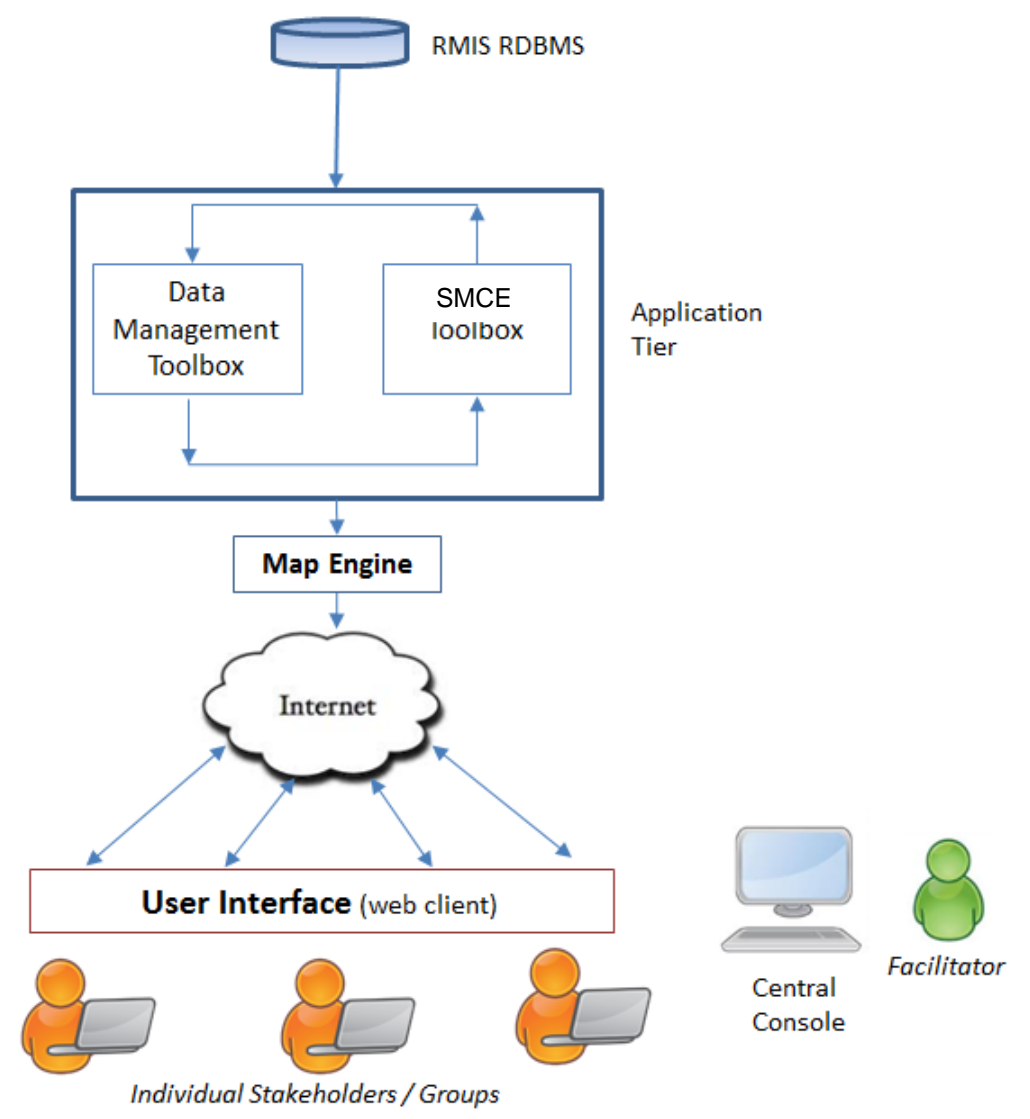

Figure 7-5: System Architecture of SMCE Modeller

\subsubsection{Visualization and Interface}

The risk mapping module is made available through a custom-designed interface of the RMIS with the provision that it provides for map visualization and the option for initiating the SMCE Modeller as shown in Figure 7-6. This 
graphical display provides a user with familiarity of the area to identify the spatial disposition of industrial risk as a result of the selection of a set of criteria and providing them with preference weights. Once the SMCE Modeller is activated, the module provides functionalities to a user or user group, who have been provided access to a planning session, to choose from a list of factor maps which are present in the RMIS knowledge base.

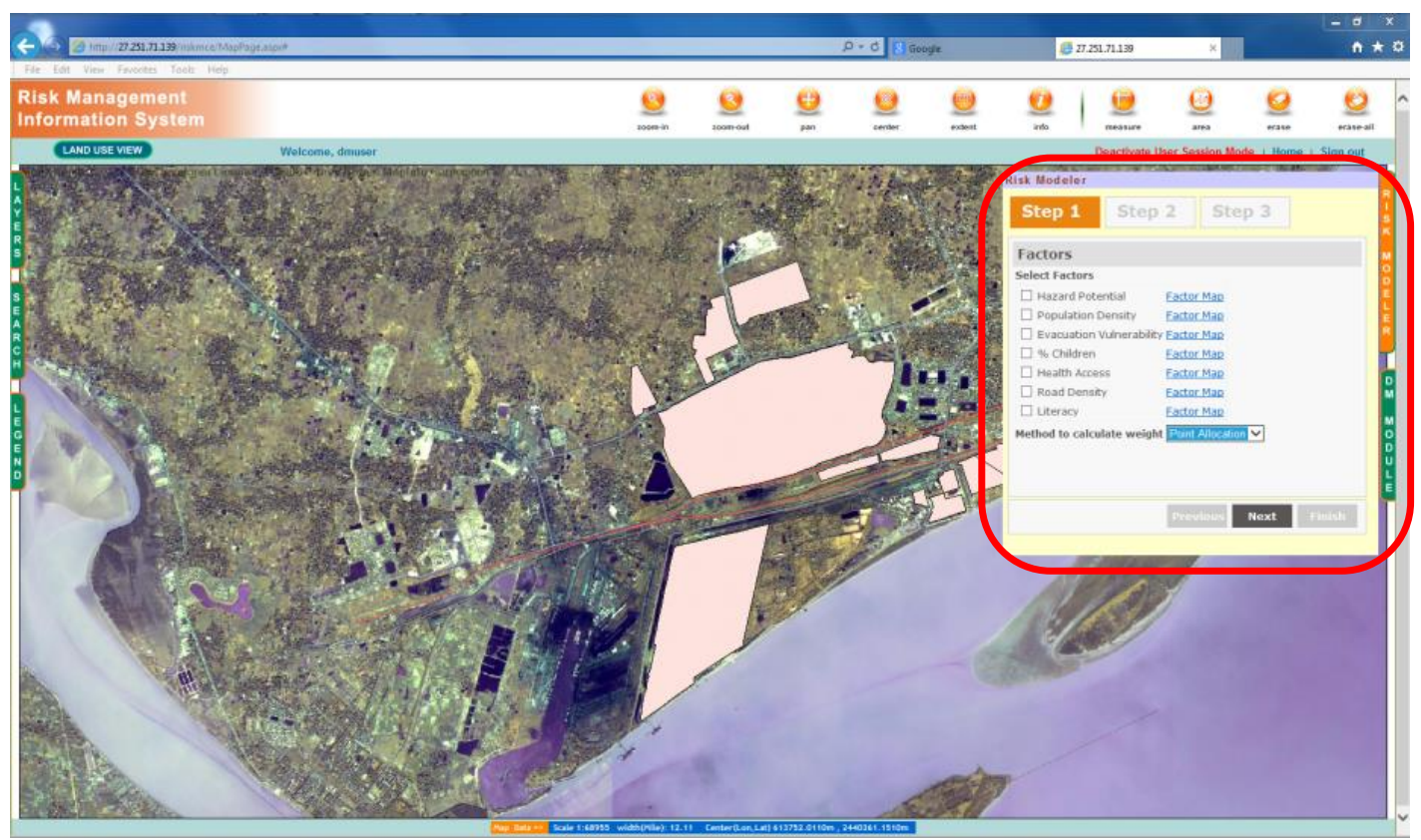

Figure 7-6: Interface of SMCE Risk Mapper

The user is then able to undertake multi-criteria evaluation by using the SMCE wizard and involving 3 linked steps:

- Specify a goal for undertaking the planning session and select criteria considered to be relevant as in Figure 7.7(a)i

- Allocate preferences to each of the factors based on point allocation, rank-sum or an AHP weighting method as in Figure 7.7(b);

- Select an aggregation method of which only weighted linear combination option is provided for the time-being as in Figure 7.7(c). On clicking 'finish', the tool initiates the requisite computations at the server end. 


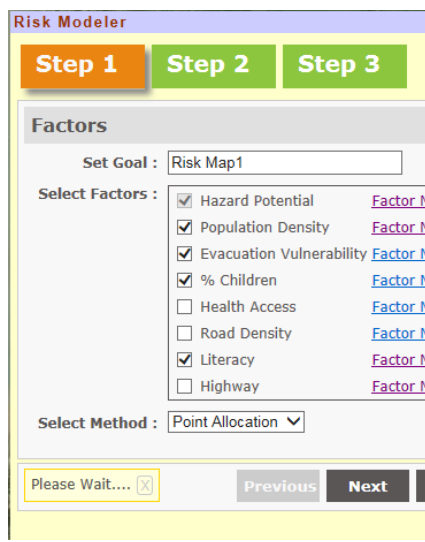

(a) Step 1 : select map layers and method to calculate weight

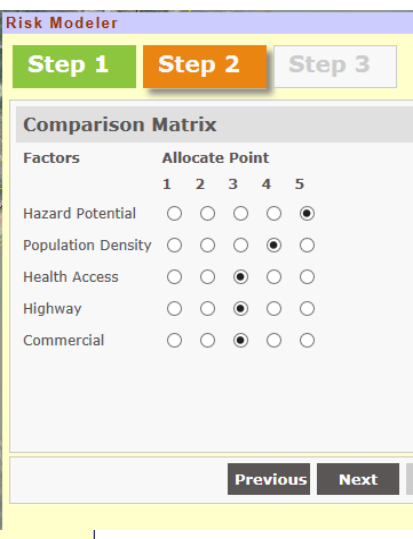

(b) Step 2 : assign

points/ranks to map layers

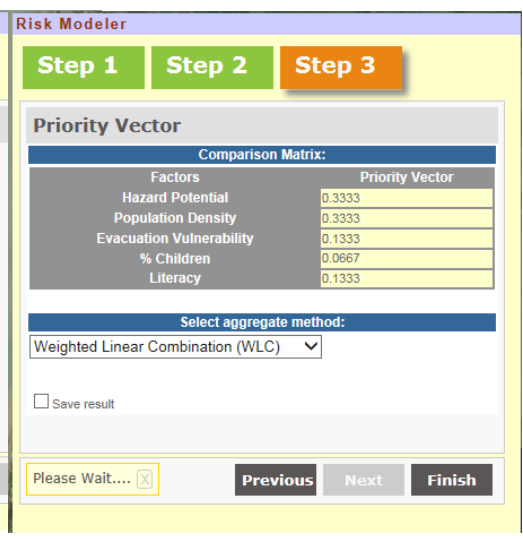

(c) Step 3 : select aggregation method

Figure 7-7: Stepwise progression of SMCE Risk Modeller wizard

Each planning session is to be moderated by a moderator sitting at a central console. The individual stakeholders or groups representing a stake (e.g. industry, community, administration) would be sitting on individual systems which have a connection established to the planning session. This mechanism is implemented by providing each individual stakeholder/group as well as the moderator access to a planning session through uniquely generated identities with pre-defined roles set by the system administrator (like usergroup1, 2, 3... and moderator). After each individual stakeholder or group performs an SMCE session, the results of the session are stored in the RMIS database as a temporary vector map which is initiated for each user/user group in the session. The conception of the SMCE Modeller Tool takes into account the fact that starting from the selection of criteria to assigning of criteria weights would involve deliberations and negotiations within the group. It is also expected that as a part of the iterative scenario exploration process, a number of alternative scenarios would be considered by the group before a final group outcome is decided upon.

Another level of collaboration and consensus making could be initiated at the higher level through the moderator. The moderator who has access to the Decision Maker's Module through the DM Wizard can see the maps created by each individual stakeholder/group sitting at the central console, as is shown in Figure 7-8 (a) and the outcomes maps of each group can be projected for all individuals / groups in the planning session to view. In a subsequent step, in discussion with the groups, the moderator may allocate weights to maps generated by each individual / group or apply a group decision rule like to capture the views of different stakeholder individuals/groups as shown in Figure 7-8 (b) to generate a composite decision map which can be considered to be the outcome of online collaboration in risk and suitability mapping. 


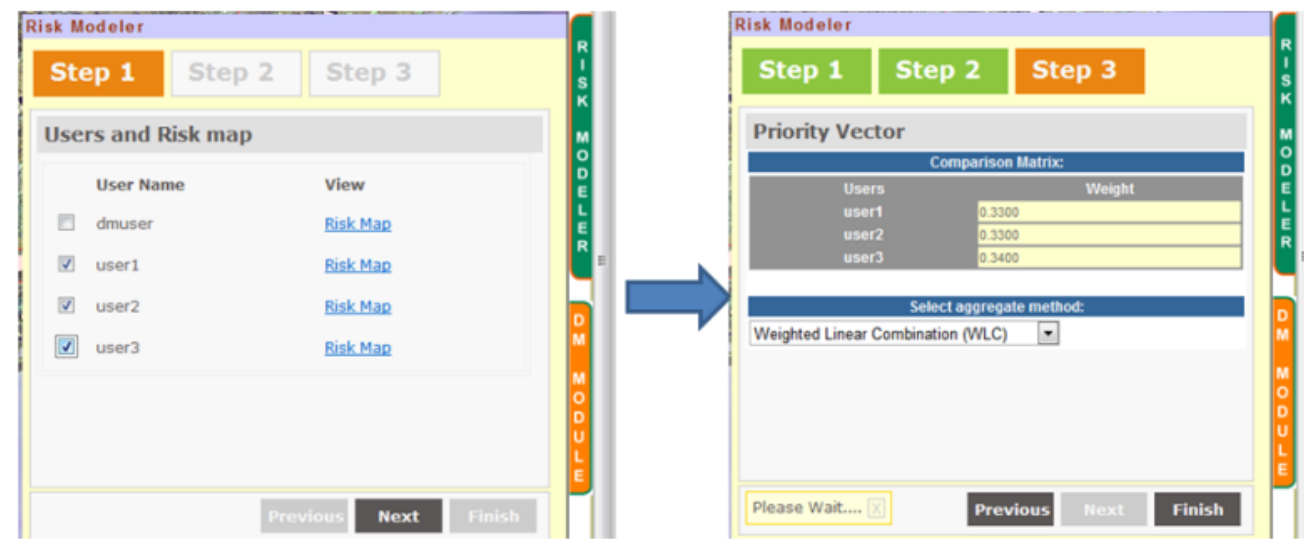

Figure 7-8: Stages in DM Module (a) Selecting user maps (b) Allocating weights for SMCE

With regard to the visualization of the final outcome of a planning session, the interface provides the user with a map display that indicates the levels of risk or suitability in terms of four pre-defined levels based on normalisation of scores from 0 to 1 : high - red; high-medium - orange; medium-low yellow and low - green through an overlay on the map of the study area.

\subsection{Demonstration of Collaborative PSS}

In order to demonstrate the SMCE Modeller, we hypothetically consider a group decision environment where several stakeholders or stakeholder groups representing different views have assembled in a decision room environment. Such an environment can be organised by making available several consoles in the same physical room, with a group user access to a planning session provided to each console. It is also factored that a set of spatial indicators have been developed for the study area in question in a specified grid-mesh format and prepared as a vector map layer. The indicators have also been standardised based on expert knowledge of how each indicator would influence a particular goal.

The objective of each planning exercise is to make participants from diverse stakeholder groups to deliberate and build exploratory planning scenarios with a particular goal, consider several alternative scenarios by varying the choice of factors and their preferential weightings, and then arrive at a consensus through a process of negotiations. We consider two specific goals which the SMCE Modeller can presently be used for building scenarios and demonstrate the application. 


\subsubsection{Indicator Based Risk Mapping}

In this example, the goal for the participants organised in one or several groups would be to understand the risk levels in the study area taking into account several risk related indicators. Such indicators may include risk derived through quantitative methods in addition to other dimensions of risk representing vulnerability, exposure and resilience to risk which are important from the normative standpoint. The SMCE Modeller wizard provides the scope for setting a planning goal, and several options with which the SMCE can be undertaken. Once the goal of the SMCE Modeller is set to 'risk mapping', a selected set of indicators having a potential bearing to risk and which have been pre-decided by experts appear in the factor list. It is possible to name the alternative as "risk map1" so that the scenario can be saved in the relational database and used for reference, if required, for later deliberations. Once the factors are selected, the second step provides the users to accord a weight to each factor by using 3 different methods - point allocation, rank sum and AHP, which is then normalised in a scale of 1 and indicated as priority vectors. The following factors were selected and weights allocated for this particular example run:

- Hazard Potential - 0.33

- Population Density - 0.33

- Evacuation Vulnerability - 0.13

- Distance to School - 0.13

- Vulnerable Population - 0.06

It is possible that the users may go back and make changes to the weights, if they feel that appropriate refection of a particular factor or factors are not occurring in the normalised distribution of weights. At this point, the users also has the choice of running the SMCE model using the WLC method and obtain a visual output in the form of a 'risk map' which shows a distribution of risk in the area in terms of a normative range - red as high (highest $25 \%$ values), orange ( $25-50 \%)$, and yellow $(50-75 \%)$ as medium and green as low $(75-100 \%)$. In addition, a pop-up window summarises the estimated population which is present and the approximate area under each risk level. The output risk map with associated information is presented in Figure 7-9. 


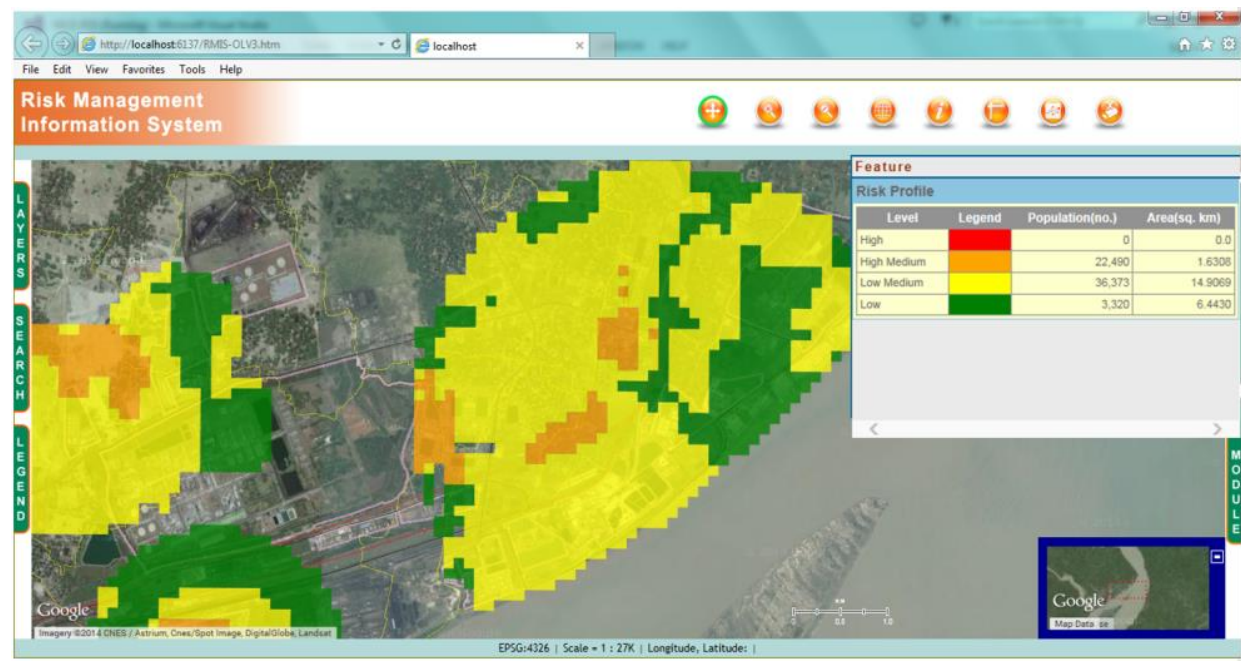

Figure 7-9: Output of Risk Mapping Scenario

It is possible to save number of 'riskmap' alternatives generated during a planning session, from one or several consoles. In the next level, it is possible to aggregate the scores generated through the multiple scenario run alternatives through a second level SMCE or combine them utilising a group decision rule.

\subsubsection{Suitability Analysis and Mapping}

The SMCE Modeller can also be used as a planning support tool to undertake suitability analysis of land for future development taking into account industrial hazard, vulnerability and other relevant planning criteria. It is expected that a set of criteria is selected and standardised through a group exercise, involving experts, in a preceding planning session. The suitability analysis planning session can then be utilised by planning stakeholders to generate several alternate siting alternatives through choice and weighing of a set of criteria, and then evaluating them through SMCE. Table 7-3 presents the selected criteria and weights for residential and industrial suitability respectively. The evaluation outcomes are presented in Figures 7-10 and 711. 
Table 7-3: Criteria and weights for Industrial and Residential suitability analysis using SMCE Risk Modeller

\begin{tabular}{lll}
\hline Industrial Suitability (criteria) & Standardisation & Weights \\
\hline Population Density & -ve linear & 0.29 \\
Distance to Highway & + ve linear & 0.17 \\
Distance to Port & + ve linear & 0.11 \\
Distance to Commercial & -ve linear & 0.17 \\
Distance to Habitat & -ve linear & 0.23 \\
\hline Residential Suitability (criteria) & & \\
\hline Hazard Potential & -ve linear & 0.31 \\
$\begin{array}{l}\text { Population Density } \\
\text { Accessibility Health (distance to health }\end{array}$ & -ve linear & 0.18 \\
centre) & +ve linear & 0.18 \\
$\begin{array}{l}\text { Accessibility to Railway Station } \\
\text { (distance) }\end{array}$ & +ve linear & 0.12 \\
Accessibility Commercial (distance) & +ve linear & 0.18 \\
\hline
\end{tabular}

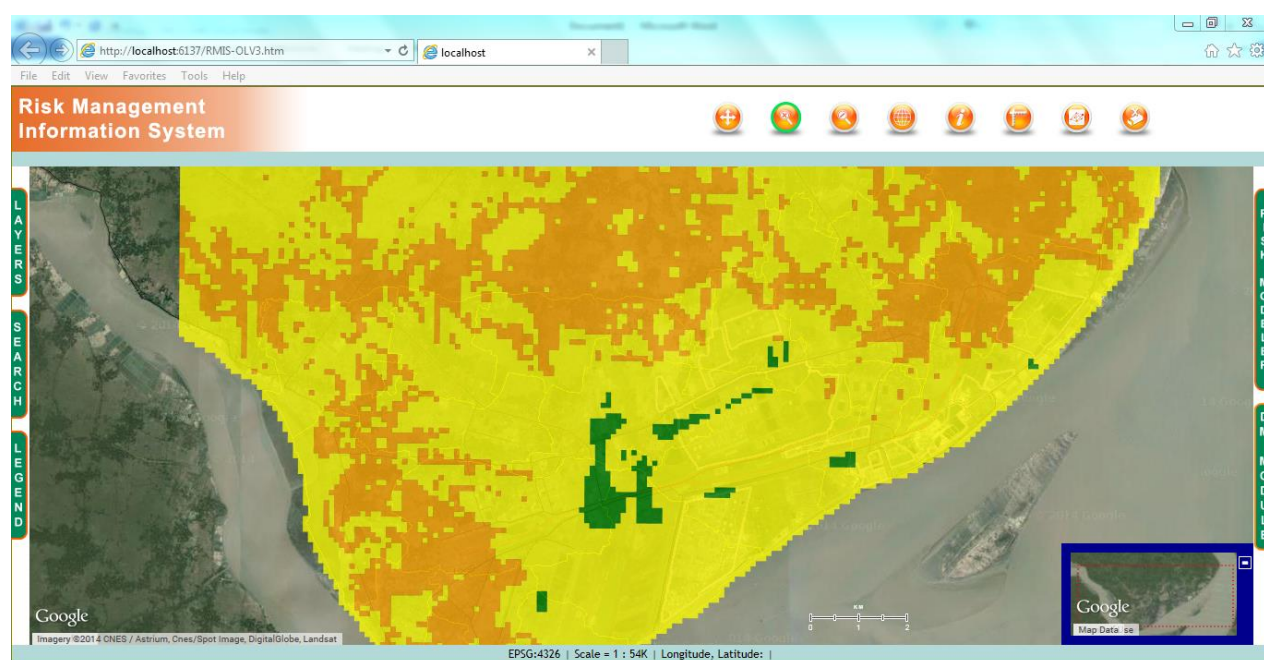

Figure 7-10: Industrial suitability alternative 


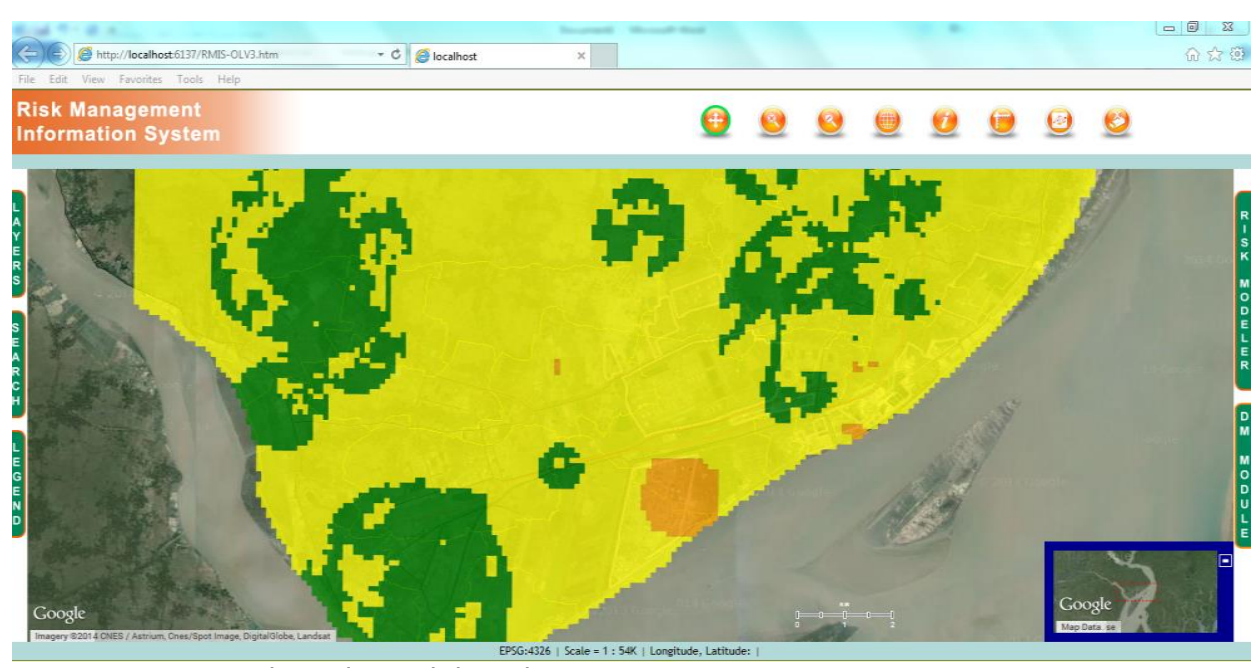

Figure 7-11: Residential suitability alternative

\subsection{Discussion}

The SMCE Planner is a part of the RMIS prototype platform which has been conceptualised to make available a choice of online tools that could provide support on industrial risk management decisions and to inform the spatial planning process in India. It is in line with recent polices adopted by the Indian government that focuses increasingly on building and using knowledge base from various sources to proactively guide disaster risk management activities as per the mandate of the Disaster Management Policy, 2009 (GoI:MoHA, 2009). Taking advantages of interoperability to share information and map services, it is also expected that the SMCE Planner can process knowledge made available by other agencies and be able to provide a composite output to a group of users. This in turn would lead to development of more normative approaches that are based on the conceptualization and development of indicators on the various aspects of hazard and vulnerability, mapping them spatially and synthesizing them to form a composite risk map providing a more representative and acceptable picture of risk prevailing in an area of concern (Davidson, 1997; Hinkel, 2011; Kappes et al., 2012). For example, the tool can be used for supporting a coherent methodology for combination of natural hazard maps (e.g. floods, earthquakes) which may be relevant for an area, along with associated vulnerabilities and deliver a multihazard risk map to guide spatial planning efforts (Greiving et al., 2006). A prerequisite to such SMCE based risk modelling and mapping, would be to reach a consensus on hazard and vulnerability indicators and formulating uniform methodologies for developing indicator maps and having requisite data made available as interoperable map services through the National Spatial Data Infrastructure (NSDI) or the National Urban Information System (NUIS) (NSDI, 2010) (GoI:MoUD, 2006). 
From the industrial risk focused planning perspective, previous experience in India has shown that technically driven approaches to management of environmental and risk issues have had their limitations. Adoption of such an approach, which in the risk case, would mean setting of numerical risk acceptability levels would have to be implemented through regulatory standards. But competent authorities in India often do not have sufficient resources to ensure its implementation or monitor conformance to standards (USEPA, 2005). Comparatively, a planning toolset that is guided by technical inputs from an area level risk assessment process and provides scope for adaptation through the devising of workable indicators have a higher chance of being accepted by the stakeholders who play a role in local urban area level planning. This may also influence the risk assessment process with an increasing emphasis on the vulnerability dimension which is influenced significantly by physical, social, cultural and educational aspects, not reducing the importance of hazard analysis (Cardona, 2004; Cutter, 1994).

The collaborative risk and suitability assessment process enabled through the SMCE Planner proposes a new channel for promoting deliberation and collaboration between stakeholders in planning compared to existing and traditional methods involving public meetings, hearings and consultations, etc. which have been commonly used in India for arriving at decisions on topics related to environmental and risk related concerns. Many such existing methods, for example those involved in environmental impact assessment (EIA) process, have been criticized because of their inability to include stakeholder's opinion into the decision making process. Comparatively, the risk mapping process involving an online Risk Mapping Tool can provide a viable alternative by providing access through web-GIS based thin client interface and which is not restricted by time, location or accessibility to specialized DSS software tools thereby seeking a better level of participation through an transparent, active and interactive decision making environment (Balram et al., 2009; Boroushaki et al., 2010b; Jelokhani-Niaraki et al., 2012).

Though the SMCE Planner makes the whole process of SMCE more accessible to stakeholders compared to the use of commercial GIS solutions having functionality for undertaking SMCE analysis, the automation of the process also brings in a few limitations. It takes into consideration the fact that experts have already worked together to discuss and agree upon hazard and vulnerability criteria, prepared spatial data based on application of a set of analytical tools (hazard analysis, interpolation, etc.), decided their ranking on an agreed upon scale and finally stored them in the RMIS database for the Risk Mapper to use. While it is accepted that the analytical-deliberative model based on which the tool is developed does account for the experts to 
undertake preliminary work before the decision makers come into the picture and try to arrive at consensual decisions after considering information made available to them, it does reduce the flexibility of the users to consider a new source of data or information which may be considered to be more relevant by the participants at a given time and place. 


\section{Chapter 8 - Conclusions}

The central research question discussed in this thesis examines the interplay between different aspects of industrial risk management in India and how an online platform can support risk actors in improving the efficiency and effectiveness of decision-making. The first part of the thesis (Chapter 2 and 3 ) discusses the current state of research in these areas through a survey of recent literature and also presents a perspective of the current situation prevailing in India. In the second part, Chapter 4 presents a SDI oriented framework for a web-based industrial risk information system that can provide users and decision makers the first level of qualitative analysis based on information stored in the system. Thereafter, Chapters 5, 6 and 7 further discusses specific decision and planning support systems that focus on key aspects of the decision-making problems related to industrial risk, both in the short and long term. This final chapter provides a synthesis of the key issues discussed in the earlier chapters and reflect on the solutions to the research questions arrived at through this research. Finally, the thesis ends with discussions on the scope for further research and innovation in the field of information, decision and planning support systems for industrial risk management.

\subsection{Consolidation of Conceptual and Methodological Framework}

In this section, we further consolidate the conceptual framework, as adapted from Liebowitz (1997) in the introductory Chapter and re-examine its relevance with regard to the research questions and some of the solutions arrived at through this thesis.

Level 1: Risk World View - Understanding Issues pertaining to Governance and management of industrial risk in the Indian Context

Level 2: Theory and Methods - Delineation of methodologies for estimating damage, estimating risk and its use as an indicator for guiding planning decisions

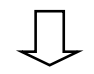

Level 3: Decision \& Planning Support - Providing decision support capability to different aspects of risk management process<smiles>C1C2CC3C1CC23</smiles>

Level 4: Use and Effectiveness - Testing the effectiveness and efficiency of risk oriented decision and planning support systems to risk actors and users in general

Figure 8-1 - Conceptual Framework for this Research 
Following is a re-capitulation and discussion centred on the four step conceptual framework and the theoretical perspectives, methodological aspects and implementation context for this research.

\subsubsection{Risk World View}

Reviews showed that policy pertaining to industrial risk management in India is still evolving, in spite of 30 years having elapsed after the Bhopal industrial accident. There is still no clear policy on governance of industrial risk however, certain inter-linkages between other related policy statements of the government like the disaster management policy, environmental policy and the draft land use utilisation policy. On the regulatory front, there are Acts and Rules that focus on management of industrial hazards. Indian regulatory regime for environment and risk management happen to be extremely dynamic - numerous alterations to the main body of the regulation occur through amendments proposed by competent authorities or agencies owning a regulation. Specific provisions of industrial risk regulations focus on identification of hazards and application of management tools like safety audits and risk assessment, the results of which can then be accounted for managing risk. However, the scientific basis for industrial hazard and risk related regulation is not well established. For example, there are no clear guidelines for a risk assessment methodology to be followed or any specific levels of risk laid down which can provide a benchmark for risk evaluation by hazardous industries. The responsibilities of competent authorities with regard to management of industrial risk is also not well laid out in regulations. Additionally, the lack of institutional capacity also affects effective implementation and monitoring of compliance to regulatory provisions. In view of such existing gaps in policy and regulatory framework, amplification of industrial risk continue to occur in more than hundred hazardous industrial clusters where clusters of hazardous industries continue to operate.

The other obvious aspect that assumes considerable importance in a democratic society like India is the views and opinions of the stakeholder with regard to risk. This research provided substantial opportunities to interact with risk actors and stakeholders at various levels - interactions were had with policy and regulatory bodies like the MOEFCC, NDMA, State Pollution Control Boards, Factories Inspectorates to understand their view on industrial risk management and decision making process for risk mitigation and control. In addition, a range of other risk actors including planning agencies, industry associations, land revenue department, association and groups were engaged with. The interactions revealed that there is clearly a lack of understanding of the basis for risk regulation and controls amongst many risk actors. In addition, many stakeholders, including the planning community found 
procedures for industrial risk assessment to be overtly prescriptive and its outcomes to be technical. This leads to insufficient understanding of the basis for risk mitigation actions, especially if they are to be adopted in areas outside of hazardous units. But nonetheless, sufficient engagement could be built with these stakeholders to be able to understand their needs and requirements from an information and decision support platform, that could provide the necessary information and support decision making at different stages of risk management.

\subsubsection{Theory and Methods}

The theory and practice of industrial risk assessment, risk evaluation and consideration of risk mitigation alternatives are quite complex and presents a domain that can benefit from the use of decision and planning support tools. However, an in-depth assessment of the Indian system revealed that there is presently no detailed methodological guidance on industrial risk assessment and this came across as a significant gap in the research. Regulations or associated guidance do not provide any clarity on methods to be used for consequence estimation, consideration of probability for accidental events, or for calculation of risk values. Experience in other countries, especially through benchmarking studies undertaken in European countries, shows that the lack of a harmonised or standard methodology can lead to substantial variation in results of risk assessment and may lead to decisions which may not be consistent or robust. In addition, there is no risk acceptability criteria in India based on which planning decisions for risk mitigation can be evaluated. On the other side, very few urban planning agencies have clearly articulated policies and procedures outlined that account for adverse effects of industries, in terms of either hazards they pose or their pollution potential, into the plans for further development of an industrial area.

The existing scenario therefore provides considerable scope and opportunity to apply a decision or planning support system oriented approach and for adopting a standardised methodology to risk based planning and decisionmaking. If the formulation of such methods is undertaken based on dialogue and deliberations with relevant risk actors, it has the potential to make decisions for risk mitigation more acceptable to the stakeholders.

\subsubsection{Decision \& Planning Support}

Several proto-types of decision and planning support systems in the domain of industrial risk management have been designed and developed as a part of this research. This includes a spatial risk management information system (RMIS) which provide the first level of decision support functionality and required information to decision makers to aid in decision making and then 
further supported by the information platform. Thereafter, considering this platform as the foundation, three other systems have been implemented: 1 . planning and managing industrial emergencies; 2 . assessment of risk using a QRA based method; and 3. an indicator based system that can guide spatial planning decisions in a collaborative manner. These systems have the advantage of pooling in information from an interoperable web based platform, use a consistent set of methodologies and provide relevant guidance at every step to a user to navigate the technological aspects involved in risk assessment and planning. Some of the key issues and conclusions on the four systems designed and implemented are presented below:

Risk Management Information System: The RMIS has been designed to be the base information management platform and provides analytical capabilities to decision makers and relevant information to risk actors through a web-GIS interface. Developed further based on the objectives of the ERRIS project, the RMIS design has been undertaken taking into consideration an interoperable and context-aware SDI framework, with information services which would be capable of integrating and sharing information from several sources. The system conceptualization accounts for consolidation of information on industrial hazard sources, elements at risk and vulnerabilities, other planning related information and real-time information from sensors.

The RMIS portal may be considered to be an information-driven DSS that supports focused queries on risk information, enables map visualization, provides outputs in form of tables and charts that analyse data from backend database thereby presenting relevant information to stakeholders based on their needs. The RMIS functionalities cover all the regulatory information dissemination or sharing requirements that hazardous industries are required to convey to regulators, or interested stakeholders who can be affected by industrial accidents. With further development, it has the potential to provide value added information such as risk maps for industrial areas which can, for example, be used by insurance companies for deciding premiums or by people to make home buying decisions.

Emergency Planning and Response: The Emergency Decision Support System (EDSS) have been designed with the objective of providing a distributed tool for aiding decision making during industrial emergency planning and response exercises. Key aspects that have been factored in its conceptualisation are the difficulties in consolidating a wide array of information from different sources while planning for or responding to an industrial emergency and the need for quick decision-making. Subsequently, through its visualization and information dissemination interface, it can 
convey the required information to stakeholders based on need so that appropriate preventive and protective actions can be taken up to reduce damages and save injuries to vulnerable people. A key advantage of the EDSS would be that it provides the scope for the decision makers to act on updated information, undertake dynamic modelling of potential consequences, and provide a live 'emergency plan' in line with regulatory requirements instead of the paper plans. Reviews have shown that the paper plans submitted to regulators are often found to outdated or lack vital information that may be required by emergency planners and responders at the time when an accident unfolds. The other advantage of adopting an IT based solution for emergency management would be the ability to integrate information from online sensors to provide real time picture on dynamic aspects like prevailing wind direction, the position of emergency responders.

QRA Risk Mapper: At present, there is no standardised and consistent methodology that can be used by regulators, industry or other stakeholders for estimating risks at an area level for a hazardous industry cluster, understand and adopt decisions on safeguards or mitigations measures based on cumulative level of risk which prevails. The QRA Risk Mapper provides the scope for adoption of a harmonised science based methodology for risk estimation that can be operated and shared through a distributed system and provide necessary support for management of risks through the regulatory and planning framework. The QRA Risk Mapper has been conceptualised and designed so that it synchronises hazard and vulnerability related information from the RMIS database and integrates with risk calculation models and tools, to provide a cumulative risk map of an area to assess the risk prevailing in an area. Based on such visualization of risk levels at a resolution of a $100 \mathrm{~m}$ grid, area level spatial planning decisions on where to site a new hazardous industry, residential or commercial area can be made in an existing industrial town.

PSS for Risk Guided Land Use Planning: In a country like India which is witnessing fast paced economic development and having a high density of population, urban planners are bound to witness conflicting interests amongst stakeholders on the suitability of land for further development of industries and meeting the housing and recreational needs of people. The MCE PSS provides a system for guiding land use planning at local level through the development of indicators, providing for choice of hazard and vulnerability based indicators to planning stakeholders, which through a multi-criteria analysis provides a framework for guiding the suitability of future land use development proposals. The PSS design allows for participation and deliberation to occur through the system interface and through discussions amongst stakeholders leading to choices being made and corresponding planning scenarios to be evaluated leading to negotiated solutions on land 
use planning. It is expected that support systems like the MCE-PSS will be used in order to arrive at land utilization zones (LUZs) and land use management areas (LMAs) as per the draft National Land Utilization Policy formulated by the GoI.

\subsubsection{Use and Effectiveness}

The evaluation of the information, decision and planning support tools by potential domain experts and user groups would be a key factor that would influence the success of the tools, when deployed. Several methodologies have been formulated to evaluate or test whether a decision or planning support system is capable of providing appropriate guidance to a decision in an appropriate situational context. Also, whether the decision support is guiding the decision maker in the right direction is an important consideration for industrial risk related decisions, where mistakes can be costly and may lead to higher damages. For example, decision making on which route to take for emergency evacuation during a toxic release is often has to be guided by the footprint of the plume and on which a reasonable estimate has to be obtained through consequence modelling. A wrong prediction can put the life of survivors at risk. For emergency response purposes, such testing and evaluation leading to calibration and fine tuning of the system, can be undertaken through realistic mock drills at site or through table top exercises wherein the accuracy of decisions as well as the time taken to get a response organised can be evaluated. Several other elements related to systems effectiveness like information quality, system quality and the capability of decision support functions can be tested through evaluation exercises, which are custom designed for a particular system.

This research provided limited scope for evaluation of the decision and planning support systems developed. Though feedback of potential users was considered at a number of stages during system development, formal evaluation or testing of the systems were limited. The only formal testing for the EDSS and the QRA Risk Mapper was undertaken as a part of national level workshop where 16 prospective users from different states participated and provided feedback through a customised questionnaire, after being trained in the use of the system. The exercise was organised more with the goal of testing few potential evaluation methods and use the feedback for designing a robust and formal evaluation framework for the systems. However, the design and application of such a framework remains as workin-progress. It is the expectation that this will be a key line of enquiry pursued with regard to further research related to information, decision and planning support systems for industrial risk management in India. 


\subsection{Deployment of RMIS Platform}

The deployment and implementation of the RMIS along with the decision and planning support systems designed and developed through this research needs to be seen in context of several key aspects. First, traditional methods of sourcing and updating information for risk management, especially the sourcing of hazard related information from industry through the regulatory channel, has been a major problem area. Though, significant emphasis has been accorded to the consolidation and use of information and knowledge to be able to make better decisions during risk and disaster events, availability of valid information still remain a key problem. The ERRIS project, which led to the formulation of this research, established that taking a voluntary and participative approach to gathering such information can be seen as a feasible alternative to keep hazard source related information current and updated.

Second, though tremendous progress in ICT is being witnessed in India and NSDI initiative being worked on for more than a decade, the availability of spatial information in the public domain as information services that can be consumed for decision support is quite limited. For example, though the information exists, population data at the lowest administrative level (the village or municipality ward) is not available in spatial form through any of the government managed information portals. In contrast, the RMIS is designed in a way that it would seek information on related domains like cadastre and population information as interoperable geospatial information services. This would only be possible with appropriate data sharing policies being implemented through the NSDI framework.

Third, as for the decision and planning support tools, acceptance for use with risk actors and related stakeholders would require the validation of the methods and models used for hazard and vulnerability analysis and risk estimation. Preferably, such calibration of the tools have to be done in collaboration with regulators and agencies like the NDMA that focus on improvement of risk based decision making, so that the risk actors are convinced about the utility of decision support, backed by scientific evidence. It is quite probable that the models and rule bases used in the tools may need to be further refined, as more knowledge is gained and usability aspects like dealing with complex data points, certainty of simulation results, and the level of expertise of users are better understood through a planned implementation process.

Fourth, in order to ensure that the methods used in building the decision logic in the tools developed are traceable and do not present themselves as a 'black-box' but more as a system for solving a complex problem needing 
computational support, laying down the methods through guidance manuals would be priority. Also, for users to gain comfort and familiarity with the systems, validation and practical exercises will need to be designed so that the rationality and the usefulness of the decision support tools can be tested.

\subsection{Future Research}

Though several industrial accidents have occurred in India in 30 years post the Bhopal disaster, research on governance and management of industrial risk has been few and far between, if the number of related publications are taken into account. In addition, the focus of most of the researches undertaken has been on the technical domain that focuses on hazard and risk analysis, but less on the correlation with governance, policy and its implementation for attaining better safeguards and protection for society from such risks. Also, not many researches have focused on crossfertilization between related domains as risk mitigation and spatial planning.

This research has attempted to build a bridge between ICT applications and the domain of industrial risk management with the objective of improving the governance of risk. It is expected that the conceptualization and design of the set of information, decision and planning support systems undertaken through this research would generate interest in further research in India on how industrial risk policies, regulations and methods can be formulated and applied in practice to make society safer. In addition, the exploration of possibilities for implementation of these systems at scale would result in research on how such systems can be further refined and adapted to needs of risk actors. An immediate area of research also would be to undertake detailed studies into the effectiveness of the systems and to bring out gaps which could be addressed through further research. 


\section{References}

Abdolhamidzadeh, B. (2013). Decision Support Systems for Preventing Domino Effects. In R. Genserik \& C. Valerio (Eds.), Domino Effects in the Process Industries (pp. 296-323). Amsterdam: Elsevier.

Adelman, L. (1992). Evaluating decision support and expert systems. New York: John Wiley and Sons.

AIChE/CCPS. (2000). Guidelines for Chemical Process Quantitative Risk Analysis (2nd Edition): Center for Chemical Process Safety.

Ale, B. J. M. (2002). Risk assessment practices in The Netherlands. Safety Science, 40(1-4), 105-126. doi: http://dx.doi.org/10.1016/S09257535(01)00044-3

Alexander, D. (2002). Principles of Emergency Planning and Management. Hertfordshire, England: Terra Publishing.

American Industrial Hygiene Association, E. R. P. E. R. P. W. E. E. L. C. AIHA 2008 Emergency Response Planning Guidelines (ERPG) and Workplace Environmental Exposure Levels (WEEL) Handbook: Aiha.

An, N., Liu, G., \& Kazar, B. (2010). Using Geospatial Web Services Holistically in Emergency Management. In P. Zhao \& L. Di (Eds.), Geospatial Web Services : Advances in Information Interoperability: IGI Global.

Andrienko, G., Andrienko, N., Jankowski, P., Keim, D., Kraak, M.-J., MacEachren, A., \& Wrobel, S. (2007). Geovisual analytics for spatial decision support: Setting the research agenda. Int. J. Geogr. Inf. Sci., 21(8), 839-857. doi: 10.1080/13658810701349011

Annoni, A., Bernard, L., Douglas, J., Greenwood, J., Laiz, I., Lloyd, M., . . . Usländer, T. (2005). Orchestra: Developing a Unified Open Architecture for Risk Management Applications. In P. Oosterom, S. Zlatanova, \& E. Fendel (Eds.), Geo-information for Disaster Management (pp. 1-17): Springer Berlin Heidelberg.

Annoni, A., Craglia, M., Ehlers, M., Georgiadou, Y., Giacomelli, A., Konecny, M., . . . Schade, S. (2011). A European perspective on Digital Earth. International Journal of Digital Earth, 4(4), 271-284. doi: 10.1080/17538947.2011.582888

Armstrong, M. P. (1993). Perspectives on the development of group decision support systems for locational problem solving. Geographic Systems.

Armstrong, M. P., Densham, P. J., \& Rushton, G. (1986). Architecture for a microcomputer based spatial decision support system. Paper presented at the Proceedings, Second International Symposium on Spatial Data Handling: July 5-10, 1986, Seattle, Washington, USA.

Ayres, R. U., \& Rohatgi, P. K. (1987). Bhopal: Lessons for technological decision-makers. Technology in Society, 9(1), 19-45. doi: 10.1016/0160-791x(87)90028-5 
Baesi, S., Abdolhamidzadeh, B., Hassan, C. R. C., Hamid, M. D., \& Reniers, G. (2013). Application of a multi-plant QRA: A case study investigating the risk impact of the construction of a new plant on an existing chemical plant's risk levels. Journal of Loss Prevention in the Process Industries, 26(5), 895-903. doi: http://dx.doi.org/10.1016/j.jlp.2012.11.005

Balram, S., Dragicevic, S., \& Feick, R. (2009). Collaborative GIS for spatial decision support and visualization. Journal of Environmental Management, 90(6), 1963-1965. doi: http://dx.doi.org/10.1016/j.jenvman.2008.07.014

Bandyopadhyay, D., \& Paul, N. (2008). ERRIS: A GIS Based Framework for Managing Industrial Risks in India. Paper presented at the Municipalika: Making Cities Work, Mumbai, India.

Bandyopadhyay, D., Paul, N., Sengupta, A., Westen van, C., \& Veen van der, A. (2013). Bridging Industrial Risk Management Deficits in India using a Geo-ICT Tool. In A. K. Gupta, S. S. Nair, F. Bemmerlien-Lux, \& S. Chatterji (Eds.), Disaster Management and Risk Reduction - Role of Environmental Knowledge. New Delhi: Narosa.

Barrett, M., Sahay, S., \& Walsham, G. (2001). Information Technology and Social Transformation: GIS for Forestry Management in India. The Information Society, 17(1), 5-20. doi: 10.1080/019722401750067397

Basta, C., Neuvel, J. M. M., Zlatanova, S., \& Ale, B. (2007). Risk-maps informing land-use planning processes: A survey on the Netherlands and the United Kingdom recent developments. Journal of Hazardous Materials, 145(1-2), 241-249. doi: 10.1016/j.jhazmat.2006.11.032

Batty, M. (2007). Planning support systems: progress, predictions and speculations on the shape of things to come. Paper presented at the Seminar on Planning Support for Urban and Regional Analysis, Lincoln Institute of Land Policy, Cambridge, MA.

Beck, U. (1999). World Risk Society: Wiley.

Beinat, E., \& Nijkamp, P. (1998). Multi-criteria analysis for land use management. Dordretch, the Netherlands: Kluwer Academic Publishers.

Bhaduri, B., Bright, E., Coleman, P., \& Urban, M. (2007). LandScan USA: a high-resolution geospatial and temporal modeling approach for population distribution and dynamics. GeoJournal, 69(1-2), 103-117. doi: 10.1007/s10708-007-9105-9

Bhargava, H. K., Power, D. J., \& Sun, D. (2007). Progress in Web-based decision support technologies. Decision Support Systems, 43(4), 1083-1095. doi: http://dx.doi.org/10.1016/j.dss.2005.07.002

Bhatnagar, S., \& Chawla, R. (2005). Bhoomi: Online Delivery of Record of Rights, Tenancy and Cultivation to Farmers in Karnataka. In $\mathrm{H}$. 
Wajahat \& A. Manoj (Eds.), Land Reforms in India-Computerization of Land Records. New Delhi: SAGE Publications.

Binda, M., Contini, S., \& Fabbri, L. (2009). On software interoperability for accident consequence assessment Scientific and Technical Research series. Italy: Joint Research Centre - Institute for the Protection and Security of the Citizen.

Birkmann, J. (2007). Risk and vulnerability indicators at different scales: Applicability, usefulness and policy implications. Environmental Hazards, 7(1), 20-31. doi: http://dx.doi.org/10.1016/j.envhaz.2007.04.002

Black, P., \& Stockton, T. (2009). Basic Steps for Development of Decision Support Systems. In A. Marcomini, G. W. Suter, \& A. Critto (Eds.), Decision Support Systems for Risk Based Management of Contaminated Sites. New York: Springer Science + Business Media.

Blong, R. (2003). A new damage index. Natural Hazards(1), 1-23.

Boerboom, L. G. J. (2010). Integrating Spatial Planning and Decision Support System Infrastructure and Spatial Data Infrastructure. Paper presented at the GSDI 12 World Conference Singapore.

Bonvicini, S., Ganapini, S., Spadoni, G., \& Cozzani, V. (2012). The Description of Population Vulnerability in Quantitative Risk Analysis. Risk Analysis, 32(9), 1576-1594. doi: 10.1111/j.15396924.2011.01766.x

Boroushaki, S., \& Malczewski, J. (2010a). Measuring consensus for collaborative decision-making: A GIS-based approach. Computers, Environment and Urban Systems, 34(4), 322-332. doi: http://dx.doi.org/10.1016/j.compenvurbsys.2010.02.006

Boroushaki, S., \& Malczewski, J. (2010b). ParticipatoryGIS: A Web-Based Collaborative GIS and Multicriteria Decision Analysis. URISA Journal, Vol. 22, No. 1.

Bortenschlager, M., Leitinger, S., Rieser, H., \& Steinmann, R. (2007). Towards a P2P-Based GeoCollaboration System for Disaster Management. Paper presented at the GI-Days 2007 - Young Researchers Forum.

Bottelberghs, P. H. (2000). Risk analysis and safety policy developments in the Netherlands. J. Hazard Mater., 71(1-3), 59-84. doi: 10.1016/S0304-3894(99)00072-2

Brovelli, M. A., Quang, T. X., \& Fenoy, G. (2012). Managing Satellite Precipitation Data (PERSIANN) Through Web GeoServices: A Case Study in North Vietnam In S. Zlatanova, R. Peters, A. Dilo, \& H. J. Scholten (Eds.), Intelligent Systems for Crisis Management: Springer.

BRZO. (1999). Besluit Risico's Zware Ongevallen 1999. Staatsblad 234.

Bubbico, R., Di Cave, S., \& Mazzarotta, B. (2004). Risk analysis for road and rail transport of hazardous materials: a GIS approach. Journal of Loss 
Prevention in the Process Industries, 17(6), 483-488. doi: http://dx.doi.org/10.1016/j.jlp.2004.08.011

Büchele, B., Kreibich, H., Kron, A., Thieken, A., Ihringer, J., Oberle, P., . . . Nestmann, F. (2006). Flood-risk mapping: contributions towards an enhanced assessment of extreme events and associated risks. Nat. Hazards Earth Syst. Sci., 6(4), 485-503. doi: 10.5194/nhess-6-4852006

Cahen, B. (2006). Implementation of new legislative measures on industrial risks prevention and control in urban areas. Journal of Hazardous Materials, 130(3), 293-299. doi: http://dx.doi.org/10.1016/j.jhazmat.2005.07.029

Campagna, M., Montis, D. A., Isola, F., Lai, S., Pira, C., \& Zoppi, C. (2012). Planning Support Tools: Policy Analysis, Implementation and Evaluation. Paper presented at the 7th International Conference on Informatics and Urban and Regional Planning INPUT Cagliari.

Cardona, D. O. (2004). The need for rethinking the concepts of vulnerability and risk from a holistic perspective: a necessary review and criticism for effective risk management. In G. Bankoff, G. Frerks, \& D. Hilhorst (Eds.), Mapping vulnerability : disasters, development and people. London: Earthscan.

Carpignano, A., Golia, E., Di Mauro, C., Bouchon, S., \& Nordvik, J. P. (2009). A methodological approach for the definition of multi-risk maps at regional level: first application. Journal of Risk Research, 12(3-4), 513-534. doi: 10.1080/13669870903050269

Carton, L. J., \& Thissen, W. A. H. (2009). Emerging conflict in collaborative mapping: Towards a deeper understanding? Journal of Environmental Management, 90(6), 1991-2001. doi: http://dx.doi.org/10.1016/j.jenvman.2007.08.033

Carver, S. J. (1991). Integrating multi-criteria evaluation with geographical information systems. International Journal of Geographical Information Systems.

Casal, J. (2008). Chapter 8 Quantitative risk analysis Evaluation of the Effects and Consequences of Major Accidents in Industrial Plants (Vol. Volume 8, pp. 291-331): Elsevier.

Chakrabarti, U. K., \& Parikh, J. K. (2013). Risk-based route evaluation against country-specific criteria of risk tolerability for hazmat transportation through Indian State Highways. Journal of Loss Prevention in the Process Industries, 26(4), 723-736. doi: http://dx.doi.org/10.1016/j.jlp.2013.02.006

Chen, K., Blong, R., \& Jacobson, C. (2001). MCE-RISK: integrating multicriteria evaluation and GIS for risk decision-making in natural hazards. Environmental Modelling \& Software, 16(4), 387-397. doi: http://dx.doi.org/10.1016/S1364-8152(01)00006-8 
Chen, R., Sharman, R., Chakravarti, N., Rao, H. R., \& Shambhu, J. (2008). Emergency Response Information System Interoperability: Development of Chemical Incident Response Data Model. Journal of the Association for Information Systems, Volume 9(3).

Chouhan, T. R. (2005). The unfolding of Bhopal disaster. Journal of Loss Prevention in the Process Industries, 18(4-6), 205-208. doi: 10.1016/j.jlp.2005.07.025

Christou, M., Gyenes, Z., \& Struckl, M. (2011). Risk assessment in support to land-use planning in Europe: Towards more consistent decisions? Journal of Loss Prevention in the Process Industries, 24(3), 219-226. doi: http://dx.doi.org/10.1016/j.jlp.2010.10.001

Christou, M., Struckl, M., \& Biermann, T. (2006). Land use planning guidelines in the context of article 12 of the Seveso II Directive 96/82/EC as amended by Directive 105/2003/EC: European Commission Joint Research Centre, Institute for the Protection and Security of the Citizen, EUR 22634 EN FR DE.

Christou, M. D., \& Mattarelli, M. (2000). Land-use planning in the vicinity of chemical sites: Risk-informed decision making at a local community level. Journal of Hazardous Materials, 78(1-3), 191-222. doi: 10.1016/s0304-3894(00)00223-5

Contini, S., Bellezza, F., Christou, M. D., \& Kirchsteiger, C. (2000). The use of geographic information systems in major accident risk assessment and management. J. Hazard Mater., 78(1-3), 223-245. doi: 10.1016/S0304-3894(00)00224-7

Cova, T. J. (1999). GIS in emergency management. In M. F. G. P.A. Longley, D.J. Maguire, D.W. Rhind (eds.) (Ed.), Geographical Information Systems: Principles, Techniques, Applications and Management ( $\mathrm{pp}$. 845 - 858). New York: John Wiley \& Sons.

Cova, T. J., \& Church, R. L. (1997). Modelling community evacuation vulnerability using GIS. Int. J. Geographical Information Science, $11(8), 763-784$.

COVO. (1982). Risk analysis of six potentially hazardous industrial objects in the Rijnmond area, a pilot study. Dordrecht, The Netherlands.

Cozzani, V., Antonioni, G., Landucci, G., Tugnoli, A., Bonvicini, S., \& Spadoni, G. (2013). Quantitative assessment of domino and NaTech scenarios in complex industrial areas. Journal of Loss Prevention in the Process Industries(0). doi: http://dx.doi.org/10.1016/j.jlp.2013.07.009

Cozzani, V., Antonioni, G., \& Spadoni, G. (2006). Quantitative assessment of domino scenarios by a GIS-based software tool. Journal of Loss Prevention in the Process Industries, 19(5), 463-477. doi: http://dx.doi.org/10.1016/j.jlp.2005.11.007

Cozzani, V., Bandini, R., Basta, C., \& Christou, M. D. (2006). Application of land-use planning criteria for the control of major accident hazards: A 
case-study. J. Hazard Mater., 136(2), 170-180. doi: 10.1016/j.jhazmat.2005.12.031

Cozzani, V., Gubinelli, G., \& Salzano, E. (2006). Escalation thresholds in the assessment of domino accidental events. Journal of Hazardous Materials, 129(1-3), 1-21. doi: http://dx.doi.org/10.1016/j.jhazmat.2005.08.012

Craglia, M., de Bie, K., Jackson, D., Pesaresi, M., Remetey-Fülöpp, G., Wang, C., . . . Woodgate, P. (2011). Digital Earth 2020: towards the vision for the next decade. International Journal of Digital Earth, 5(1), 4-21. doi: citeulike-article-id: 10258967

doi: 10.1080/17538947.2011.638500

Cutter, S. L. (1994). Environmental Risks and Hazards. New Jersey: Prentice Hall.

Das, A., Gupta, A. K., \& Mazumder, T. N. (2012). A comprehensive risk assessment framework for offsite transportation of inflammable hazardous waste. Journal of Hazardous Materials, 227-228(0), 8896. doi: http://dx.doi.org/10.1016/j.jhazmat.2012.05.014

Davidson, R. A. (1997). An Urban Earthquake Disaster Risk Index (Vol. Report nr. 21). Stanford: The John A. Bume Earthquake Engineering Center, Stanford University.

Davis, F. D. (1989). Percieved Usefulness, Percieved Ease of Use, and User Acceptance of Information Technology. MIS Quarterly, 13 : 3.

de Freitas, C. M., Porto, M. F. S., de Freitas, N. B. B., Pivetta, F., Arcuri, A. S., Moreira, J. C., \& Machado, J. M. H. (2001). Chemical safety and governance in Brazil. Journal of Hazardous Materials, 86(1-3), 135151. doi: http://dx.doi.org/10.1016/S0304-3894(01)00251-5

De Maio, C., Fenza, G., Gaeta, M., Loia, V., \& Orciuoli, F. (2011). A knowledge-based framework for emergency DSS. Knowledge-Based Systems, 24(8), 1372-1379. doi: http://dx.doi.org/10.1016/j.knosys.2011.06.011

de Silva, F. N. (2001). Providing spatial decision support for evacuation planning: a challenge in integrating technologies. Disaster Prevention and Management, 10(1), 11 - 20.

De Souza Jr, A. B. (2000). Emergency Planning for Hazardous Industrial Areas: A Brazilian Case Study. Risk Analysis, 20(4), 483-494. doi: 10.1111/0272-4332.204046

DeLone, W., \& McLean, E. (2003). The DeLone and McLean model of information systems success: a ten-year update. Journal of Management Information Systems, 19 (4): 9-30.

Delvosalle, C., Fievez, C., Pipart, A., \& Debray, B. (2006). ARAMIS project: A comprehensive methodology for the identification of reference accident scenarios in process industries. Journal of Hazardous Materials, 130(3), 200-219. doi: http://dx.doi.org/10.1016/j.jhazmat.2005.07.005 
Delvosalle, C., Fiévez, C., Pipart, A., Fabrega, J. C., Planas, E., Christou, M., \& Mushtaq, F. (2005). Identification of reference accident scenarios in SEVESO establishments. Reliability Engineering \& System Safety, 90(2-3), 238-246. doi: http://dx.doi.org/10.1016/j.ress.2004.11.003

Demichela, M., Pilone, E., \& Camuncoli, G. Land use planning around major risk installations: From EC directives to local regulations in Italy. Land Use Policy(0). doi: http://dx.doi.org/10.1016/j.landusepol.2013.06.015

Densham, P. N. (1991). Spatial Decision Support Systems (pp. 403 - 412).

Denzer, R. (2005). Generic integration of environmental decision support systems - state-of-the-art. Environmental Modelling \& Software, 20(10), 1217-1223. doi: http://dx.doi.org/10.1016/j.envsoft.2004.09.004

Dilo, A., \& Zlatanova, S. (2011). A data model for operational and situational information in emergency response. Applied Geomatics, 3(4), 207218. doi: $10.1007 / \mathrm{s} 12518-011-0060-2$

Dragicevic, S. (2008). Modeling and Visualization for Spatial Decision Support. Cartography and Geographic Information Science, 35(2), 75-76. doi: 10.1559/152304008784090612

Drummond, W. J. (2008). The Future of GIS in Planning: Converging Technologies and Diverging Interests. Journal of the American Planning Association, 72(2).

Council Directive 96/82/EC on the control of major-accident hazards involving dangerous substances (Official Journal L010, 14/01/1997 P. 00130033) (1996).

Eduljee, G. H. (2000). Trends in risk assessment and risk management. Science of The Total Environment, 249(1-3), 13-23. doi: http://dx.doi.org/10.1016/S0048-9697(99)00507-0

Elmahdi, A., \& McFarlane, D. (2009). A decision support system for sustainable groundwater management. Case study: Gnangara Sustainability Strategy - Western Australia. In C. A. Brebbia \& V. Popv (Eds.), Water resources management V. Proceedings of the Fifth International Conference on Sustainable Water Resources Management. Malta.

Erden, T., \& Coskun, M. Z. (2007). Interfacing Emergency management with GIS-aided spatial decision support systems Paper presented at the International Symposium on Modern Technologies, Education and Professional Practice in Geodesy and Related FIelds, Sofia.

ERM. (2002). Preparation of Country level Vulnerability Map for Industrial Hazards: MoEF India.

ESRI. Transportation Data Models. Retrieved 03.11.2015, from http://www.esri.com/industries/transport/community/data model

Directive 2012/18/EU of the European Parliament and the Council of 4 July 2012 on the control of major-accident hazards involving dangerous 
substances, amending and subsequent repealing Council Directive, 96/82/EC, ("Seveso Directive III") (2012).

Fabbri, K., \& Weets, G. (2005). ICT for Environmental Risk Management in the EU Research Context. In P. Oosterom, S. Zlatanova, \& E. Fendel (Eds.), Geo-information for Disaster Management (pp. 51-56): Springer Berlin Heidelberg.

Fabbri, L., \& Contini, S. (2009). Benchmarking on the evaluation of major accident-related risk assessment. Journal of Hazardous Materials, 162(2-3), 1465-1476. doi: http://dx.doi.org/10.1016/j.jhazmat.2008.06.071

Fabiano, B., Currò, F., Palazzi, E., \& Pastorino, R. (2002). A framework for risk assessment and decision-making strategies in dangerous good transportation. Journal of Hazardous Materials, 93(1), 1-15. doi: http://dx.doi.org/10.1016/S0304-3894(02)00034-1

FAO. (1996). Guidelines for land-use planning. Rome.

Fedra, K. (1998). Integrated risk assessment and management: overview and state of the art. J. Hazard Mater., 61(1-3), 5-22. doi: 10.1016/S0304-3894(98)00102-2

Fedra, K., \& Winkelbauer, L. (2002). A Hybrid Expert System, GIS, and Simulation Modeling for Environmental and Technological Risk Management. Computer-Aided Civil and Infrastructure Engineering, 17(2), 131-146. doi: 10.1111/1467-8667.00261

Code of Federal Regulations: Title 44-Emergency Management and Assistance (1997).

FEMA. (2004). FEMA's Methodology for Estimating Potential Losses from Disasters. In U. F. E. M. Agency (Ed.).

Flowerdew, R., \& Green, M. (1992). Developments in areal interpolation methods and GIS. The Annals of Regional Science, 26(1), 67-78. doi: $10.1007 / B F 01581481$

Fotheringham, A. S., Charlton, M. E., \& Brunsdon, C. (1998). Geographically weighted regression: a natural evolution of the expansion method for spatial data analysis. Environment and Planning A, 30(11), 19051927.

Gahlout, S. S., Guha, A., Kumar, A., \& A., K. (2009). GIS and Online Emergency Planning and Information Reporting System for Chemical Accidents in India. Paper presented at the Second India Disaster Management Congress, New Delhi.

Geertman, S., \& Stillwell, J. (2004). Planning support systems: an inventory of current practice. Computers, Environment and Urban Systems, 28(4), 291-310. doi: 10.1016/s0198-9715(03)00024-3

Geertman, S., \& Stillwell, J. (2009). Planning Support Systems: Best Practice and New Methods. New York: Springer. 
Gemino, A., \& Parker, D. (2009). Use Case Diagrams in Support of Use Case Modeling: Deriving Understanding from the Picture. Journal of Database Management, 20(1), 1-24.

Georgiadou, P. S., Papazoglou, I. A., Kiranoudis, C. T., \& Markatos, N. C. (2007). Modeling emergency evacuation for major hazard industrial sites. Reliability Engineering \& System Safety, 92(10), 1388-1402. doi: http://dx.doi.org/10.1016/j.ress.2006.09.009

Georgiadou, P. S., Papazoglou, I. A., Kiranoudis, C. T., \& Markatos, N. C. (2010). Multi-objective evolutionary emergency response optimization for major accidents. J. Hazard. Mater., 178(1-3), 792803. doi: 10.1016/j.jhazmat.2010.02.010

Georgiadou, Y., Puri, S. K., \& Sahay, S. (2005). Towards a potential research agenda to guide the implementation of Spatial Data InfrastructuresA case study from India. International Journal of Geographical Information Science, 19(10), 1113-1130. doi: $10.1080 / 13658810500286950$

Gheorghe, A., \& Vamanu, D. (2004). Decision support systems for risk mapping: viewing the risk from the hazards perspective. Journal of Hazardous Materials, 111(1-3), 45-55. doi: http://dx.doi.org/10.1016/j.jhazmat.2004.02.010

G.S.R.347(E) : Rules on Emergency Planning, Preparedness and Resposne for Chemical Accidents (1996).

S.O. 966(E) \& S.O.57(E) : Manufacture, Storage and Import of Hazardous Chemical Rules, 1989 (as amended 2000) (2000).

GoI:MoEF. (2006). The National Environment Policy.

GoI:MoHA. (2009). National Policy on Disaster Management

GoI:MoRD. (2013). Draft National Land Utilisation Policy. New Delhi.

GoI:MoUD. (1996). Urban Development Plans Formulation and Implementation (UDPFI) Guidelines. New Delhi.

GoI:MoUD. (2006). National Urban Information System (NUIS) Design and Standards: Town and Country Planning Organization.

GoI:NDMA. (2007). National Disaster Management Guidelines, Chemical Disaster (Industrial). New Delhi, India: National Disaster Management Authority, Govt. of India.

Goodchild, M., Guo, H., Annoni, A., Bian, L., de Bie, K., Campbell, F., . . . Woodgate, P. (2012). Next-generation Digital Earth. Proceedings of the National Academy of Sciences. doi: citeulike-article-id:10826773

doi: $10.1073 /$ pnas.1202383109

Goodchild, M. F. (2008). The use cases of digital earth. International Journal of Digital Earth, 1(1), 31-42. doi: 10.1080/17538940701782528

Goodchild, M. F. (2011). Citizens as Sensors: The World of Volunteered Geography The Map Reader (pp. 370-378): John Wiley \& Sons, Ltd.

Gore, A. (1999). The Digital Earth : Understanding Our Planet in the 21 st Century. Photogrammetric Engineering and Remote Sensing, 65(5). 
Gorry, G. A., \& Morton, M. S. (1971). A framework for management information systems. Sloan Management Review.

Gouldson, A. (2004). Risk, regulation and the right to know: exploring the impacts of access to information on the governance of environmental risk. Sustainable Development, 12(3), 136-149. doi: 10.1002/sd.237

Greiving, S., Fleischhauer, M., \& Lückenkötter, J. (2006). A Methodology for an integrated risk assessment of spatially relevant hazards. Journal of Environmental Planning and Management, 49(1), 1-19. doi: 10.1080/09640560500372800

Greiving, S., Pratzler-Wanczura, S., Sapountzaki, K., Ferri, F., Grifoni, P., Firus, K., \& Xanthopoulos, G. (2012). Linking the actors and policies throughout the disaster management cycle by "Agreement on Objectives" - a new output-oriented management approach. Nat. Hazards Earth Syst. Sci., 12(4), 1085-1107. doi: 10.5194/nhess-121085-2012

Grønberg, C. (1999). LUPACS - Land Use Planning And Chemical Sites.

Groot, R., \& McLaughlin, J. (2000). Geospatial data infrastructure: concepts, cases, and good practice. New York: Oxford University Press.

Gupta, A. K., Suresh, I. V., Misra, J., \& Yunus, M. (2002). Environmental risk mapping approach: risk minimization tool for development of industrial growth centres in developing countries. Journal of Cleaner Production, 10(3), 271-281. doi: http://dx.doi.org/10.1016/S09596526(01)00023-3

Habibullah, W., \& Ahuja, M. (2005). Land reforms in India - computerization of land records.

Ltd, 315 p. (Vol. Vol. 10): SAGE Publications Pvt.

Haddow, G., Bullock, J., \& Coppola, D. P. (2013). Introduction to Emergency Management: Elsevier.

Harris, B. (1989). Beyond Geographic Information Systems : Computers and the Planning Professional. Journal of American Planning Association.

Herrera-Viedma, E., Herrera, F., \& Chiclana, F. (2002). A consensus model for multiperson decision making with different preference structures. IEEE Transactions on Systems, Man, and Cybernetics - Part A: Systems and Humans, 32(3), 394-402. doi: 10.1109/TSMCA.2002.802821

Hinkel, J. (2011). "Indicators of vulnerability and adaptive capacity": Towards a clarification of the science-policy interface. Glob. Environ., 21(1), 198-208. doi: 10.1016/j.gloenvcha.2010.08.002

HSE. (1999). Control of Major Accident Hazards Regulations

HSE. (2011). PADHI - Health and Safety Executive's land use planning methodology. $\quad$ Retrieved 1.08.2014, from http://www.hse.gov.uk/landuseplanning/

HSE, U. (2005). A National Population Data Base for Major Accident Hazard Modelling. 
Ibbotson, J., Gibson, C., Wright, J., Waggett, P., Zerfos, P., Szymanski, B., \& Thornley, D. J. (2010, 19-21 July 2010). Sensors as a Service Oriented Architecture: Middleware for Sensor Networks. Paper presented at the Intelligent Environments (IE), 2010 Sixth International Conference on.

IChemE. (1992). Nomenclature for Hazard and Risk Assessment in Process Industries. Rugby: IChemE.

IRGC. (2005). White Paper on Risk Governance: Towards an integrative framework. Geneva.

ISDR. (2004). Living with Risk - A global review of disaster reduction initiatives (Vol. Volume - 1). Geneva: United Nations.

ISDR. (2005). Hyogo framework for action 2005-2015: building the resilience of nations and communities to disasters. Paper presented at the World Conference on Disaster Reduction Kobe, Hyogo, Japan.

Jankowski, P. (2009). Towards participatory geographic information systems for community-based environmental decision making. Journal of Environmental Management, 90(6), 1966-1971. doi: http://dx.doi.org/10.1016/j.jenvman.2007.08.028

Janowicz, K., Schade, S., Bröring, A., Keßler, C., Maué, P., \& Stasch, C. (2010). Semantic Enablement for Spatial Data Infrastructures. Transactions in GIS, 14(2), 111-129. doi: 10.1111/j.14679671.2010.01186.x

Jasanoff, S. (1988). The Bhopal disaster and the right to know. Social Science \& Medicine, 27(10), 1113-1123. doi: 10.1016/02779536(88)90306-1

Jelokhani-Niaraki, M., \& Malczewski, J. (2012). A Web 3.0-driven Collaborative Multicriteria Spatial Decision Support System. Cybergeo : European Journal of Geography, Systèmes, Modélisation, Géostatistiques, article 620. doi: 10.4000/cybergeo.25514

Jonkman, S. N., van Gelder, P. H. A. J. M., \& Vrijling, J. K. (2003). An overview of quantitative risk measures for loss of life and economic damage. J. Hazard Mater., 99(1), 1-30. doi: 10.1016/s03043894(02)00283-2

K“ohler, P., M“uller, M., Sanders, M., \& W“achter, J. (2006). Data management and GIS in the Center for Disaster Management and Risk Reduction Technology (CEDIM): from integrated spatial data to the mapping of risk. Nat. Hazards Earth Syst. Sci., 6, 621-628.

Kappes, M. S., Papathoma-Köhle, M., \& Keiler, M. (2012). Assessing physical vulnerability for multi-hazards using an indicator-based methodology. Appl. Geogr., 32(2), 577-590. doi: 10.1016/j.apgeog.2011.07.002

Karagiannis, G., Piatyszek, E., \& Flaus, J. (2010). Industrial emergency planning modeling: A first step toward a robustness analysis tool. $J$. Hazard Mater., 181(1-3), 324-334. doi: 10.1016/j.jhazmat.2010.05.014 
Kevany, M. J. (2003). GIS in the World Trade Center attack-trial by fire. Comput. Environ. Urban Syst., 27(6), 571-583. doi: 10.1016/s01989715(03)00015-2

Khakee, A. (1998). The Communicative Turn in Planning and Evaluation. In N. Lichfield, A. Barbanente, D. Borri, A. Khakee, \& A. Prat (Eds.), Evaluation in Planning (Vol. 47, pp. 97-111): Springer Netherlands.

Kiehle, C., \& Padberg, A. (2009). Spatial Data Infrastructures and Grid Computing: the GDI-Grid project. Paper presented at the Geophysical Research Abstracts 11 (EGU2009-4242).

Kiker, G. A., Bridges, T. S., Varghese, A., Seager, T. P., \& Linkov, I. (2005). Application of multicriteria decision analysis in environmental decision making. Integrated Environmental Assessment and Management, 1(2), 95-108. doi: 10.1897/IEAM_2004a-015.1

Klosterman, R. E. (1999). The What if? collaborative planning support system. Environment and Planning B: Planning and Design, 26(3), 393-408.

Kontić, D., Kontić, B., \& Gerbec, M. (2006). How powerful is ARAMIS methodology in solving land-use issues associated with industry based environmental and health risks? Journal of Hazardous Materials, 130(3), 271-275. doi: http://dx.doi.org/10.1016/j.jhazmat.2005.07.012

Koutsoukos, X., Kushwaha, M., Amundson, I., Neema, S., \& Sztipanovits, J. (2007). OASiS: A Service-Oriented Architecture for Ambient-Aware Sensor Networks. In F. Kordon \& O. Sokolsky (Eds.), Composition of Embedded Systems. Scientific and Industrial Issues (Vol. 4888, pp. 125-149): Springer Berlin Heidelberg.

Lahr, J., \& Kooistra, L. (2010). Environmental risk mapping of pollutants: State of the art and communication aspects. Science of The Total Environment, 408(18), 3899-3907. doi: http://dx.doi.org/10.1016/j.scitotenv.2009.10.045

Laniak, G. F., Olchin, G., Goodall, J., Voinov, A., Hill, M., Glynn, P., . . . Hughes, A. (2013). Integrated environmental modeling: A vision and roadmap for the future. Environmental Modelling \& Software, 39(0), 3-23. doi: http://dx.doi.org/10.1016/j.envsoft.2012.09.006

Lees, F. P. (1996). Loss Prevention in the Process Industries (2nd ed ed.): Butterworth-Heinemann, Oxford.

Levy, J. K., \& Taji, K. (2007). Group decision support for hazards planning and emergency management: A Group Analytic Network Process (GANP) approach. Mathematical and Computer Modelling, 46(7-8), 906-917. doi: 10.1016/j.mcm.2007.03.001

Liebowitz, J. (1997). The Handbook of Applied Expert Systems: CRC.

Linkov, I., Varghese, A., Jamil, S., Seager, T., Kiker, G., \& Bridges, T. (2005). Multi-criteria decision analysis: a framework for structuring remedial decisions at contaminated sites Comparative risk 
assessment and environmental decision making (pp. 15-54): Springer.

Liu, J., \& Zhao, F. (2005). Towards Semantic Services for Sensor-rich Information Systems. Paper presented at the Proceedings of the 2nd IEEE/CreateNet International Workshop on Broadband Advanced Sensor Networks.

Löfstedt, R., \& Boholm, А. (2009). The Earthscan reader on risk: Earthscan.

Longley, P. A., Goodchild, M. F., MacGuire, D. J., \& Rhind, D. J. (2005). Geographical Information Systems: Principles, Techniques, Management and Applications (2nd Edition ed.). New York: Wiley.

MacFarlane, R. (2005). A Guide to GIS Applications in Integrated Emergency Management: Emergency Planning College, Cabinet Office.

Maguire, D. J., \& Longley, P. A. (2005). The emergence of geoportals and their role in spatial data infrastructures. Computers, Environment and Urban Systems, 29(1), 3-14. doi: http://dx.doi.org/10.1016/j.compenvurbsys.2004.05.012

Mahmoud, M., Liu, Y., Hartmann, H., Stewart, S., Wagener, T., Semmens, D., . . . Winter, L. (2009). A formal framework for scenario development in support of environmental decision-making. Environmental Modelling \& Software, 24(7), 798-808. doi: http://dx.doi.org/10.1016/j.envsoft.2008.11.010

Malczewski, J. (1999). GIS and Multicriteria Decision Analysis. New York: Wiley.

Malczewski, J. (2004). GIS-based land-use suitability analysis: a critical overview. Progress in Planning, 62(1), 3-65. doi: http://dx.doi.org/10.1016/j.progress.2003.09.002

Malczewski, J. (2006). GIS-based multicriteria decision analysis: a survey of the literature. International Journal of Geographical Information Science, 20(7), 703-726. doi: 10.1080/13658810600661508

Mansourian, A., Rajabifard, A., Valadan Zoej, M. J., \& Williamson, I. (2006). Using SDI and web-based system to facilitate disaster management. Computers \& Geosciences, 32(3), 303-315. doi: 10.1016/j.cageo.2005.06.017

Marhavilas, P. K., Koulouriotis, D., \& Gemeni, V. (2011). Risk analysis and assessment methodologies in the work sites: On a review, classification and comparative study of the scientific literature of the period 2000-2009. Journal of Loss Prevention in the Process Industries, 24(5), 477-523. doi: http://dx.doi.org/10.1016/j.jlp.2011.03.004

Matthies, M., Giupponi, C., \& Ostendorf, B. (2007). Environmental decision support systems: Current issues, methods and tools. Environmental Modelling \& Software, 22(2), 123-127. doi: http://dx.doi.org/10.1016/j.envsoft.2005.09.005 
Mazzini, M., Contini, S., \& Volta, G. (2002). Haria-2. A computer supported approach to emergency planning, analysis and response. Risk, Decision and Policy, 7(02), 131-143. doi: doi: $10.1017 /$ S135753090200056X

McDaniels, T., Gregory, R., \& Fields, D. (1999). Democratizing Risk Management: Successful Public Involvement in Local Water Management Decisions. Risk Analysis, 19(3), 497-510. doi: 10.1023/A: 1007060931193

McIntosh, B. S., Ascough Ii, J. C., Twery, M., Chew, J., Elmahdi, A., Haase, D., . . . Voinov, A. (2011). Environmental decision support systems (EDSS) development - Challenges and best practices. Environmental Modelling \& Software, 26(12), 1389-1402. doi: http://dx.doi.org/10.1016/j.envsoft.2011.09.009

Mendonça, D. (2007). Decision support for improvisation in response to extreme events: Learning from the response to the 2001 World Trade Center attack. Decision Support Systems, 43(3), 952-967. doi: http://dx.doi.org/10.1016/j.dss.2005.05.025

Merali, Y., Papadopoulos, T., \& Nadkarni, T. (2012). Information systems strategy: Past, present, future? The Journal of Strategic Information Systems, 21(2), 125-153. doi: http://dx.doi.org/10.1016/j.jsis.2012.04.002

Moen, J. E. T., \& Ale, B. J. M. (1998). Risk maps and communication. J. Hazard Mater., 61(1-3), 271-278. doi: 10.1016/S03043894(98)00132-0

MoHA:GoI. (2004). Knowledge Management in Disaster Risk Reduction - the Indian Approach.

Molina, M., \& Bayarri, S. (2011). A multinational SDI-based system to facilitate disaster risk management in the Andean Community. Computers \& Geosciences, 37(9), 1501-1510. doi: 10.1016/j.cageo.2011.01.015

Nag, P., \& Sengupta, S. (2008). Introduction To Geographical Information Systems. New Delhi: Concept Publishing Company.

Nedović-Budić, Z. (1998). The Impact of GIS Technology. Environment and Planning B: Planning and Design, 25(5), 681-692. doi: 10.1068/b250681

Neuvel, J. M. M., Scholten, H. J., \& van den Brink, A. (2010). From Spatial Data to Synchronised Actions: The Network-centric Organisation of Spatial Decision Support for Risk and Emergency Management. Appl. Spatial Analysis. doi: 10.1007/s12061-010-9059-z

NRC. (1993). Toward a Coordinated Spatial Data Infrastructure for the Nation. Washington, D.C.: National Academy Press.

NRC. (2007). Successful Response Starts with a Map: Improving Geospatial Support for Disaster Management. Washington DC: National Research Council. 
NSDI. (2010). Content Standard for Geo-spatial Data : Data Specifications Definition of Annex Themes and Scope.

Nye, J. S., \& Donahue, J. D. (2000). Governance in a Globalizing World. Washington DC: Brookings Institutions.

O'Mahony, M. T., Doolan, D., O'Sullivan, A., \& Hession, M. (2008). Emergency planning and the Control of Major Accident Hazards (COMAH/Seveso II) Directive: An approach to determine the public safety zone for toxic cloud releases. Journal of Hazardous Materials, 154(1-3), 355-365.

doi: http://dx.doi.org/10.1016/j.jhazmat.2007.10.065

OGC. (2003). Data Models and Interoperability - An OGC Whitepaper.

OGC. (2007). Open GIS Web Processing Service.

Owens, S. (2000). 'Engaging the public': information and deliberation in environmental policy. Environment and Planning A, 32(7), 11411148.

Papamichail, K. N., \& French, S. (2005). Design and evaluation of an intelligent decision support system for nuclear emergencies. Decision Support Systems, 41(1), 84-111. doi: http://dx.doi.org/10.1016/j.dss.2004.04.014

Papazoglou, I. A., Bonanos, G. S., Nivolianitou, Z. S., Duijm, N. J., \& Rasmussen, B. (2000). Supporting decision makers in land use planning around chemical sites. Case study: expansion of an oil refinery. J. Hazard. Mater., 71(1-3), 343-373. doi: 10.1016/s03043894(99)00087-4

Pasman, H., \& Reniers, G. (2014). Past, present and future of Quantitative Risk Assessment (QRA) and the incentive it obtained from Land-Use Planning (LUP). Journal of Loss Prevention in the Process Industries(0). doi: http://dx.doi.org/10.1016/j.jlp.2013.03.004

Pe, C. S. P. S. M. D. (2005). Hazard assessment Lees' Loss Prevention in the Process Industries (Third Edition) (pp. 1-123). Burlington: Butterworth-Heinemann.

Peng, Z. R., \& Tsou, M. H. (2003). Internet GIS. Hoboken, NJ: Wiley.

Persie, v. M., C., S. v. M., Wisse, E., Tjoe-Awie, J. B., Jong, d. A. J., \& Bakker, W. (2012). Integration of Real-Time UAV Video into the Fire Brigades Crisis Management System. In S. Zlatanova, R. Peters, A. Dilo, \& H. J. Scholten (Eds.), Intelligent Systems for Crisis Management: Springer.

Pettit, C. J., Klosterman, R. E., Ruiz-Nino, M., Widjaja, I., Russo, P., Tomko, M., . . . Stimson, R. (2013). The Online What if? Planning Support System. In S. Geertman (Ed.), Planning Support Systems for Sustainable Urban Development. Berlin Heidelberg: Springer-Verlag.

Pietersen, C. M., \& van het Veld, B. F. P. (1992). Risk assessment and risk contour mapping. Journal of Loss Prevention in the Process 
Industries, 5(1), 60-63. doi: http://dx.doi.org/10.1016/09504230(92)80066-H

Porter, S., \& Wettig, J. (1999). Policy issues on the control of major accident hazards and the new Seveso II directive. Journal of Hazardous Materials, 65(1-2), 1-14. doi: http://dx.doi.org/10.1016/S03043894(98)00249-0

Porto, d., F. M., \& Freitas, M. C. (1996). Major chemical accidents in industrializing countries: The socio-political amplification of risk. Insurance: Mathematics and Economics, 18(2), 144 . doi: http://dx.doi.org/10.1016/0167-6687(96)81426-0

Power, D. J. (2008). Decision Support Systems: A Historical Overview Handbook on Decision Support Systems 1 (pp. 121-140): Springer Berlin Heidelberg.

Punihani, H., Ravi, K., Dikshit, O., \& Tiwari, R. S. (2002). Preparation of Zoning Atlas for Siting of Industries Using GIS. Indian Cartographer.

Puri, S. K. (2006). Technological frames of stakeholders shaping the SDI implementation: A case study from India. Information Technology for Development, 12(4), 311-331. doi: 10.1002/itdj.20050

Puri, S. K., \& Sahay, S. (2007). Role of ICTs in participatory development: An Indian experience. Information Technology for Development, 13(2), 133-160. doi: $10.1002 /$ itdj.20058

Radke, J., Cova, T. J., Sheridan, M. F., Troy, A., Lan, M., \& Johnson, R. (2000). Application challenges for GIScience: implications for research, education, and policy for risk assessment, emergency preparedness and response. Urban and Regional Information Systems Association (URISA) Journal, 12(2), 15-30.

Rajabifard, A., Feeney, M. E. F., \& Williamson, I. P. (2002). Future directions for SDI development. International Journal of Applied Earth Observation and Geoinformation, 4(1), 11-22. doi: 10.1016/s03032434(02)00002-8

Reniers, G., \& Faes, R. (2013). 13 - Managing Domino Effects in a Chemical Industrial Area. In R. Genserik \& C. Valerio (Eds.), Domino Effects in the Process Industries (pp. 272-295). Amsterdam: Elsevier.

Reniers, G. L. L., Ale, B. J. M., Dullaert, W., \& Foubert, B. (2006). Decision support systems for major accident prevention in the chemical process industry: A developers' survey. J. Loss Prev. Process Ind., 19(6), 604-620. doi: 10.1016/j.jlp.2006.02.005

Renn, O. (1999). A Model for an Analytic-Deliberative Process in Risk Management. Environmental Science \& Technology, 33(18), 30493055. doi: 10.1021/es981283m

Renn, O. (2006). Participatory processes for designing environmental policies. Land Use Policy, 23(1), 34-43. doi: http://dx.doi.org/10.1016/j.landusepol.2004.08.005 
Rhind, D. W. (1991). Counting the people: The role of GIS. In D. J. Maguire, M. F. Goodchild, \& D. W. Rhind (Eds.), Geographical Information Systems: Principles and Applications (Vol. Volume 1, pp. 127-137). Longman: Longman.

Rinner, C., \& Bird, M. (2009). Evaluating community engagement through argumentation maps - a public participation GIS case study. Environment and Planning B: Planning and Design, 36(4), 588-601.

Risicokaart.nl. Retrieved 26.08.2011, from http://risicokaart.nl/

Roman, D., Schade, S., Berre, A., Bodsberg, N., \& Langlois, T. J. (2009). Model as a Service (MaaS),. Paper presented at the Grid Technologies for Geospatial Applications, Workshop at Agile Hannover, Germany.

Saaty, T. L. (1979). Mathematical modeling of dynamic decisions; priorities and hierarchies with time dependence. Mathematics and Computers in Simulation, 21(4), 352-358. doi: http://dx.doi.org/10.1016/03784754(79)90004-1

Sahay, S., \& Walsham, G. (1996). Implementation of GIS in India: Organizational issues and implications. International Journal of Geographical Information Systems, 10(4), 385-404. doi: 10.1080/02693799608902086

Salvi, O., \& Debray, B. (2006). A global view on ARAMIS, a risk assessment methodology for industries in the framework of the SEVESO II directive. Journal of Hazardous Materials, 130(3), 187-199. doi: http://dx.doi.org/10.1016/j.jhazmat.2005.07.034

Scholten, H., Fruijter, S., Dilo, A., \& Borkulo, E. (2008). Spatial Data Infrastructure for Emergency Response in Netherlands. In S. Nayak \& S. Zlatanova (Eds.), Remote Sensing and GIS Technologies for Monitoring and Prediction of Disasters (pp. 179-197): Springer Berlin Heidelberg.

SEDAC. (2005). Gridded Population of the World (GPW) v3. from http://sedac.ciesin.columbia.edu/data/collection/gpw-v3

Sengupta, A., Bandyopadhyay, D., Roy, S., van Westen, C. J., \& van der Veen, A. (2015). Challenges for introducing risk assessment into land use planning decisions in an Indian context. Journal of Loss Prevention in the Process Industries. doi: http://dx.doi.org/10.1016/j.jlp.2015.10.007

Sengupta, A., Bandyopadhyay, D., van Westen, C. J., \& van der Veen, A. (2016). An evaluation of risk assessment framework for industrial accidents in India. Journal of Loss Prevention in the Process Industries, 41, 295-302. doi: http://dx.doi.org/10.1016/j.jlp.2015.12.012

Sengupta, A., Lemmen, C., Devos, W., Bandyopadhyay, D., \& van der Veen, A. (2015). Constructing a seamless digital cadastral database using colonial cadastral maps and VHR imagery - an Indian perspective. 


\section{Survey Review, 1752270615Y.0000000003. doi:} 10.1179/1752270615Y.0000000003

Sengupta, A. (2016) "Industrial Risk Assessment - an Indian Perspective", PhD dissertation, University of Twente.

SFK/TAA. (2011). Recommendation for separation disctances between establishments under the Major Accident Ordinance and Areas requiring protection within the Framework of Land use Planning.

Shen, S., Cheng, X., \& Gong, P. (2008). Sensor Web Oriented Web-Based GIS. Paper presented at the Proceedings of the 8th International Symposium on Web and Wireless Geographical Information Systems, Shanghai, China.

Shim, J. P., Warkentin, M., Courtney, J. F., Power, D. J., Sharda, R., \& Carlsson, C. (2002). Past, present, and future of decision support technology. Decis. Support Syst., 33(2), 111-126. doi: 10.1016/s0167-9236(01)00139-7

Singh, P. K. (2009). Spatial Data Infrastructure in India : Status, Governance Challenges, and Strategies for Effective Functioning. International Journal of Spatial Data Infrastructures Research, Volume 4, 359-388.

SNDR. (2002). A National Hazards Information Strategy : Reducing Disaster Losses Through Better Information: National Science and Technology Council.

Sorensen, J. H., Shumpert, B. L., \& Vogt, B. M. (2004). Planning for protective action decision making: evacuate or shelter-in-place. Journal of Hazardous Materials, 109(1-3), 1-11. doi: http://dx.doi.org/10.1016/j.jhazmat.2004.03.004

Spadoni, G., Contini, S., \& Uguccioni, G. (2003). The new version of ARIPAR in assessing and managing major risks in industrialised areas. Process Saf. Environ. Prot., 81(1), 19-30.

Spadoni, G., Egidi, D., \& Contini, S. (2000). Through ARIPAR-GIS the quantified area risk analysis supports land-use planning activities. $J$. Hazard Mater., 71(1-3), 423-437. doi: 10.1016/S03043894(99)00091-6

Spash, C. L. (2001). Broadening democracy in environmental policy processes. Environment and Planning C: Government and Policy, 19(4), 475-481.

Stern, P. C., Fineberg, H. V., Characterization, C. R., \& Council, N. R. (1996). Understanding Risk: Informing Decisions in a Democratic Society: National Academies Press.

Su, M.-D., Lin, M.-C., Hsieh, H.-I., Tsai, B.-W., \& Lin, C.-H. (2010). Multilayer multi-class dasymetric mapping to estimate population distribution. Science of The Total Environment, 408(20), 4807-4816. doi: http://dx.doi.org/10.1016/j.scitotenv.2010.06.032

Sugumaran, V., \& Sugumaran, R. (2007). Web-based Spatial Decision Support Systems (WebSDSS): Evolution, Architecture, Examples and 
Challenges. Communications of the Association for Information Systems, 19.

Technica. (1984). The SAFETI Package (Vol. I - IV). London: Technica Ltd.

Technica_Ltd. (1985). Manual of Industrial Hazard Assessment Techniques. Washington, DC: Office of Environmental and Scientific Affairs, World Bank.

Thomas, P. (2009). Bhoomi, Gyan Ganga, e-governance and the right to information: ICTs and development in India. Telematics and Informatics, 26(1), 20-31. doi: http://dx.doi.org/10.1016/j.tele.2007.12.004

Tixier, J., Dandrieux, A., Dusserre, G., Bubbico, R., Mazzarotta, B., Silvetti, B., . . . Salvi, O. (2006). Environmental vulnerability assessment in the vicinity of an industrial site in the frame of ARAMIS European project. Journal of Hazardous Materials, 130(3), 251-264. doi: http://dx.doi.org/10.1016/j.jhazmat.2005.07.020

Tugnoli, A., Gyenes, Z., Van Wijk, L., Christou, M., Spadoni, G., \& Cozzani, V. (2013). Reference criteria for the identification of accident scenarios in the framework of land use planning. Journal of Loss Prevention in the Process Industries, 26(4), 614-627. doi: http://dx.doi.org/10.1016/j.jlp.2012.12.004

Turoff, M., Chumer, M., de Walle, B. V., \& Yao, X. (2004). The Design of a Dynamic Emergency Response Management Information System (DERMIS). Journal of Information Technology Theory and Application (JITTA), Vol. 5(Iss. 4).

Tyagunov, S., Grünthal, G., Wahlström, R., Stempniewski, L., \& Zschau, J. (2006). Seismic risk mapping for Germany. Nat. Hazards Earth Syst. Sci., 6(4), 573-586. doi: 10.5194/nhess-6-573-2006

Uijt de Haag, P. A. M. (2013). Reference Manual Bevi Risk Assessments. Bilthoven, the Netherlands: National Institute of Public Health and the Environment (RIVM).

Uijt de Haag, P. A. M., \& Ale, B. J. M. (1992). Methods for the determination of possible damage: to people and objects resulting from the releases of hazardous materials (Green Book), CPR-16E (First Edition ed.). Den Haag: Committee for the Prevention of Disasters.

Uijt de Haag, P. A. M., \& Ale, B. J. M. (2005a). Guidelines for Quantitative Risk Assessment (Purple Book), CPR18E (First Edition - 1999 ed.). Den Haag, NL: Committee for the Prevention of Disasters.

Uijt de Haag, P. A. M., \& Ale, B. J. M. (2005b). Methods for the calculation of the physical effects resulting from the the releases of hazardous materials (Yellow Book), CPR 14E (First Edition - 1996 ed.). Den Haag: Committee for the Prevention of Disasters.

UN. (2007). Information on disaster risk management - Case study of five countries [Press release] 
UN. (2015). Sendai Framework for Disaster Risk Reduction 2015. Paper presented at the UN World Conference on Disaster Risk Reduction, Sendai, Japan.

UNCED. (1992). Agenda 21, New York.

UNECE. (1998). Convention on Access to Information, Public Partcipation in Decision Making and Access to Justice in Environmental Matters, Aarhus, Denmark.

UNSDI. (2008). Interim United Nations Spatial Data Infrastructure, United Nations Spatial Data Infrastructure: Netherlands Coordination Office.

Uran, O., \& Janssen, R. (2003). Why are spatial decision support systems not used? Some experiences from the Netherlands. Comput. Environ. Urban Syst., 27(5), 511-526. doi: 10.1016/s0198-9715(02)00064-9

USEPA. (2005). Environmental Compliance and Enforcement In India.

van Asselt, M. B. A., \& Renn, O. (2011). Risk governance. Journal of Risk Research, 14(4), 431-449. doi: 10.1080/13669877.2011.553730

Van Het Veld, F., Boot, H., \& Kootstra, F. (2007). RISKCURVES: a comprehensive computer program for performing a Quantitative Risk Assessment (QRA). Paper presented at the Risk, reliability and societal safety, London.

Van Westen, C. J. (2013). 3.10 Remote Sensing and GIS for Natural Hazards Assessment and Disaster Risk Management. In J. F. Shroder (Ed.), Treatise on Geomorphology (pp. 259-298). San Diego: Academic Press.

Venkatesh, V., Morris, M., Davis, G., \& Davis, F. (2003). User acceptance of information technology: Toward a unified view. MIS Quarterly, 27 (3), 425-478.

Versluis, E., van Asselt, M., Fox, T., \& Hommels, A. (2010). The EU Seveso regime in practice: From uncertainty blindness to uncertainty tolerance. Journal of Hazardous Materials, 184(1-3), 627-631. doi: http://dx.doi.org/10.1016/j.jhazmat.2010.08.082

Vescoukis, V., Doulamis, N., \& Karagiorgou, S. (2012). A service oriented architecture for decision support systems in environmental crisis management. Future Generation Computer Systems, 28(3), 593-604. doi: http://dx.doi.org/10.1016/j.future.2011.03.010

von Lubitz, D. K. J. E., Beakley, J. E., \& Patricelli, F. (2008). Disaster Management: The Structure, Function, and Significance of NetworkCentric Operations. Journal of Homeland Security and Emergency Management, 5(1). doi: 10.2202/1547-7355.1411

Vonk, G., Geertman, S., \& Schot, P. (2007). A SWOT analysis of planning support systems. Environment and Planning A, 39(7), 1699-1714.

Wahlster, W., Schwarzkopf, E., Sauermann, L., Roth-Berghofer, T., Pfalzgraf, A., Kiesel, M., . . . Sintek, M. (2006). Web 3.0: Convergence of Web 2.0 and the Semantic Web. Technology Radar volume Feature Paper Edition II/2006. 
Walker, G., Mooney, J., \& Pratts, D. (2000). The people and the hazard: the spatial context of major accident hazard management in Britain. Applied Geography, 20(2), 119-135. doi: http://dx.doi.org/10.1016/S0143-6228(99)00032-6

Walker, G., Simmons, P., Irwin, A., \& Wynne, B. (1999). Risk communication, public participation and the Seveso II directive. Journal of Hazardous Materials, 65(1-2), 179-190. doi: http://dx.doi.org/10.1016/S0304-3894(98)00262-3

Walsham, G., \& Sahay, S. (2006). Research on information systems in developing countries: current landscape and future prospects. Inf. Technol. Dev., 12(1), 7-24. doi: 10.1002/itdj.20020

Williamson, I., \& Rajabifard, A. (2003). Developing spatial data infrastructures: From concept to reality.

. London: Taylor \& Francis.

Wynne, R., \& Eijndhoven, V. J. (1991). Risk Communication in Europe. In E. Kasperson \& P. J. M. Stallen (Eds.), Communicating Health and Safety Risks to the Public. Dordrecht: Kluwer.

Yatsalo, B., Didenko, V., Tkachuk, A., Gritsyuk, G., Mirzeabasov, O., Slipenkaya, V., . . . Linkov, I. (2010). Multi-Criteria Spatial Decision Support System DECERNS: Application to Land Use Planning. Int. J. Inf. Syst. Soc. Chang., 1(1), 11-30. doi: 10.4018/jissc. 2010092902

Zerger, A., \& Smith, D. I. (2003). Impediments to using GIS for real-time disaster decision support. Comput. Environ. Urban Syst., 27(2), 123141. doi: 10.1016/s0198-9715(01)00021-7

Zhang, S., \& Goddard, S. (2007). A software architecture and framework for Web-based distributed Decision Support Systems. Decision Support Systems, 43(4), 1133-1150. doi: http://dx.doi.org/10.1016/j.dss.2005.06.001

Zhao, P., \& Di, L. (2010). Geospatial Web Services : Advances in Information Interoperability: IGI Global.

Zlatanova, S., \& Fabbri, A. G. (2009). Geo-ICT for Risk and Disaster Management

Geospatial Technology and the Role of Location in Science. In H. J. Scholten, R. Velde, \& N. Manen (Eds.), (Vol. 96, pp. 239-266): Springer Netherlands.

Zlatanova, S., Peters, R., Dilo, A., \& Scholten, H. J. (2012). Intelligent systems for crisis management: Geo-information for Disaster Management Paper presented at the Gi4DM, Enschede.

Zografos, K. G., Vasilakis, G. M., \& Giannouli, I. M. (2000). Methodological framework for developing decision support systems (DSS) for hazardous materials emergency response operations. Journal of Hazardous Materials, 71(1-3), 503-521. doi: http://dx.doi.org/10.1016/S0304-3894(99)00096-5 


\section{Biography}

Debanjan Bandyopadhyay was born in Chinsurah, a suburban town in eastern India. After completing high school, Debanjan took interest in physics and completed his BSc in 1994. Thereafter, he joined a post-graduate course in environment management and followed it up with a master's degree in business administration, specialising in information systems, from the University of Calcutta.

Building his career as a consultant and getting the

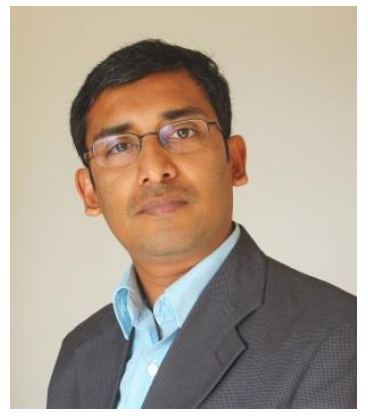
opportunity to work with a range of organisations, he was often intrigued with how policy makers and administrators in India model decisions when dealing with complex and multidisciplinary problems in environment and risk management. Focussing on these issues, he played a key role in conceiving the Environmental Risk Reporting and Information System project, a collaborative project which facilitated hazardous installations in key industrial towns to share risk related information with stakeholders of concern - this was then consolidated on a web-GIS based platform for disseminating information on industrial hazards and risk, one of the country's first such system in 2006. The foundation for his PhD research on decision and planning support systems for industrial risk management was laid then, working closely with the ITC, Netherlands and the IPSC, Italy. His other research interests include environmental policy, impact assessment and decision support tools that focus on sustainability and optimal use of land resources.

Presently, working as a Partner with Environmental Resources Management (ERM) in India, he collaborates with a team of professionals who specialise in conceptualisation and development of decision support systems.

\section{List of Publications}

\section{$\underline{\text { Peer reviewed journal articles }}$}

1. Sengupta, A., Bandyopadhyay, D., van Westen, C.J. and van der Veen, A. (2016) An evaluation of risk assessment framework for industrial accidents in India. In: Journal of Loss Prevention in the Process Industries, 41(2016), pp. 295-302.

2. Sengupta, A., Bandyopadhyay, D., Roy, S., van Westen, C.J. and van der Veen, A. (2016) Challenges for introducing risk assessment into land use planning decisions in an Indian context. In: Journal of Loss Prevention in the Process Industries, 42 (2016), pp. 14-26. 
3. Sengupta, A., Lemmen, C.H.J., Devos, W., Bandyopadhyay, D. and van der Veen, A. (2015) Constructing a seamless digital cadastral database using colonial cadastral maps and VHR imagery: an Indian perspective. In: Survey review, (2015) IN PRESS $11 \mathrm{p}$.

4. Sengupta, A., Bandyopadhyay, D., van Westen, C.J., Krausman, E. and van der Veen, A. An indicator-based framework for building vulnerability assessment to industrial accidents (under review)

\section{Book Chapters}

5. Bandyopadhyay, D., Paul, N., Sengupta, A., van Westen, C.J. and van der Veen, A. (2013) Bridging industrial risk management deficits in India using a Geo - ICT based tool. In: Disaster management and risk reduction : role of environmental knowledge / ed. by A.K. Gupta et al. New Delhi: Narosa, 2013. ISBN 978-81-8487-251-4. pp. 99-110.

6. Sengupta, A., Bandyopadhyay, D., van Westen, C.J. and van der Veen, A. (2014) Is a QRA-based method suitable to guide Land Use Planning decisions in India? in: Safety and reliability: methodology and applications: proceedings of the European safety and reliability conference, ESREL 2014, Wroclaw, Poland, 14-18 September 2014 / edited by T. Nowakowski et al. Boca Raton: CRC Press, 2014. ISBN: 978-1-315-73697-6. pp. 1401-1409.

\section{Conference Proceedings (full paper)}

7. Sengupta, A., Bandyopadhyay, D., Lemmen, C.H.J. and van der Veen, A. (2013) Potential use of LADM in cadastral data management in India. In: Proceedings of the 5th Land Administration Domain Model workshop, 24-25 September 2013, Kuala Lumpur, Malaysia. pp. 311328. 


\section{ITC Dissertation List}

https://www.itc.nl/Pub/research programme/Research-review-andoutput/PhD-Graduates 